UNIVERSIDADE DE SÃO PAULO

FACULDADE DE FILOSOFIA, LETRAS E CIÊNCIAS HUMANAS

DEPARTAMENTO DE LETRAS MODERNAS

PROGRAMA DE PÓS-GRADUAÇÃO EM ESTUDOS LINGUÍSTICOS E LITERÁRIOS EM INGLÊS

DENISE SILVA PAES LANDIM

\title{
O Inglês da EJA para a vida: \\ letramentos sociais e escolares refletidos
}

Versão Corrigida

São Paulo 
DENISE SILVA PAES LANDIM

\section{O Inglês da EJA para a vida: \\ letramentos sociais e escolares refletidos}

Versão Corrigida

Dissertação de Mestrado apresentada ao Programa de PósGraduação em Estudos Linguísticos e Literários em Inglês do Departamento de Letras Modernas da Faculdade de Filosofia, Letras e Ciências Humanas da Universidade de São Paulo, para obtenção do título de Mestre em Letras.

Orientadora: Profa. Dra. Walkyria Monte Mór

São Paulo 
Ao Beni, por ter me acolhido e impulsionado a transformar a nossa coleção de pedras e de livros jamais escritos em sonhos, lutas e conquistas. 


\section{AGRADECIMENTOS}

À minha orientadora, Profa. Dra. Walkyria Monte Mór, por sua atuação inspiradora, pela confiança em meu trabalho, generosidade intelectual e supervisão cuidadosa a esta pesquisa.

Ao Prof. Dr. Lynn Mario Trindade Menezes de Souza, pelo exemplo de criticidade e pensamento e pelos comentários enriquecedores no momento do Exame de Qualificação.

À Profa. Dra. Deusa Maria de Souza Pinheiro Passos, por seu olhar crítico e delicado e por suas valiosas contribuições quando do Exame de Qualificação.

Aos meus pais e à minha família, pela sensibilidade, carinho e apoio incondicionais, em todos os momentos em que precisei.

Aos meus amigos, pela torcida constante e pela paciência quanto aos momentos em que estive ausente, dedicando-me a este trabalho.

Aos queridos colegas e amigos do Programa de Pós-Graduação, pela convivência frutífera e pela partilha de inesquecíveis aprendizagens, descobertas, alegrias, angústias e rupturas.

Às professoras colaboradoras desta pesquisa e a suas coordenadoras, cujo acolhimento e disposição permitiram a realização deste trabalho.

Aos alunos participantes da pesquisa, que enriqueceram meus pontos de vista com a partilha de suas aprendizagens e trajetórias.

À CAPES, pelo apoio financeiro durante a pesquisa. 
BANCA EXAMINADORA 


\section{RESUMO}

Este trabalho é fruto de uma pesquisa qualitativa-interpretativa, de cunho etnográfico, que visou compreender as relações entre letramentos escolares e letramentos sociais entre alunos de Educação de Jovens e Adultos (EJA). A coleta de dados ocorreu em duas comunidades escolares, localizadas na cidade de São Paulo, com suas respectivas professoras, por meio da observação de aulas, entrevistas formais e informais e questionários.

Para compreender as relações entre letramentos escolares e sociais no contexto investigado, baseamos nossas análises nos estudos de letramentos - novos letramentos, multiletramentos, letramento crítico (KALANTZIS e COPE, 2003, 2005, 2008, 2012, 2013; GEE, 2004; KRESS 2003, 2011; LANKSHEAR e KNOBEL, 2007, 2011; LEMKE 2010; MONTE MÓR, 2006, 2007, 2013; MENEZES DE SOUZA, 2011) que levam em conta os efeitos educacionais das mudanças sociais, culturais, econômicas e políticas advindas da globalização e da cultura midiática e digital.

As análises apontaram, neste contexto de Educação de Jovens e Adultos (EJA), marcadamente sensível a questões de marginalização social dos sujeitos por ela atendidos, para tanto distanciamentos e quanto aproximações entre ambos os tipos de letramento, evidenciando as relações conflituosas entre as concepções e as práticas pedagógicas observadas.

Palavras-chave: novos letramentos; letramento crítico; Educação de Jovens e Adultos; ensino de língua estrangeira; língua inglesa. 


\begin{abstract}
This qualitative-interpretative research, with ethnographic elements, aimed at investigating the relations between school literacies and social literacies in Adult Education . Its data was collected in two school communities, in the city of São Paulo, with their respective teachers, through class observation, formal and informal interviews and questionnaires.

In order to understand such relations in the targeted context, we based our analyses in the literacies studies - new literacies, multiliteracies, critical literacies (KALANTZIS e COPE, 2003, 2005, 2008, 2012, 2013; GEE, 2004; KRESS 2003, 2011; LANKSHEAR e KNOBEL, 2007, 2011; LEMKE 2010; MONTE MÓR, 2006, 2007, 2013; MENEZES DE SOUZA, 2011), which take into consideration educational effects towards the social, cultural, economic and political changes resulting from globalization and media and digital culture.

Our analysis pointed that, especially in the context of Adult Education, markedly sensitive to issues of social marginalization of the subjects it serves, there are both distance and approximation of the two types of literacies, highlighting conflicted relations between pedagogical concepts and practices which were observed.
\end{abstract}

Key-words: new literacies; critical literacies; Adult Education; English as a Foreign Language; English language. 
INTRODUÇÃO

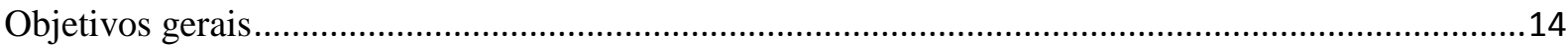

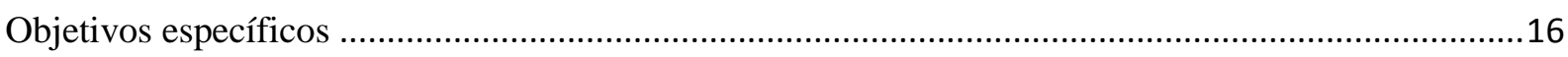

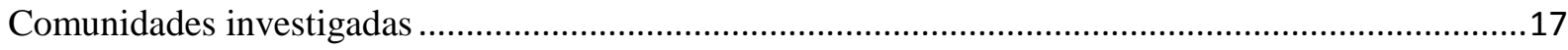

Vívian, professora de Linguagens e Códigos no Centro Educacional Transdisciplinar .......................19

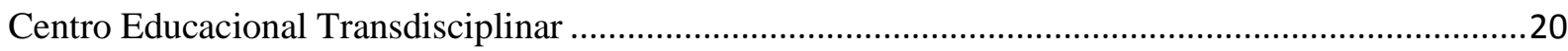

Milena, professora de língua inglesa na Escola Municipal Paulo Freire .............................................23

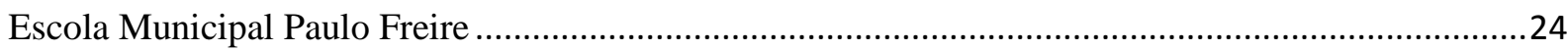

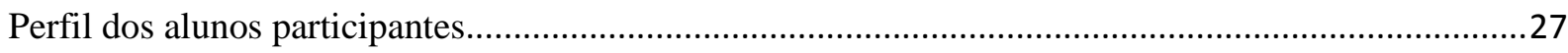

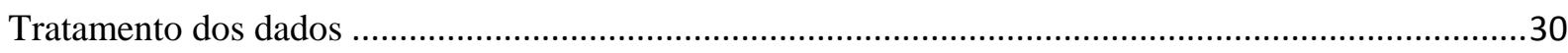

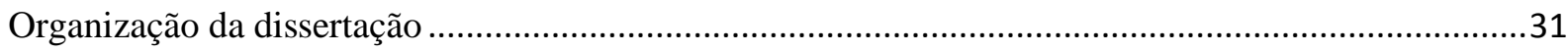

CAPÍTULO 1: BASES TEÓRICAS PARA O ENSINO DE INGLÊS NA EJA POR MEIO DOS

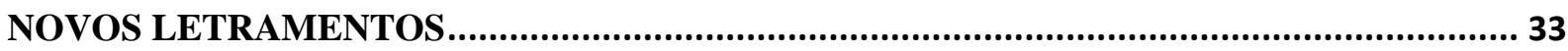

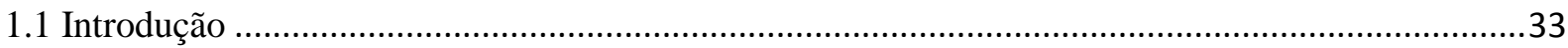

$1.2 \mathrm{O}$ ensino de inglês e os estudos de novos letramentos e multiletramentos .....................................34

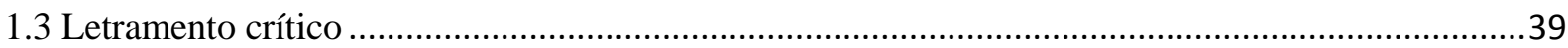

1.4 De letramento (Literacy Studies) a Novos Letramentos (New Literacy/Literacies Studies) ............42

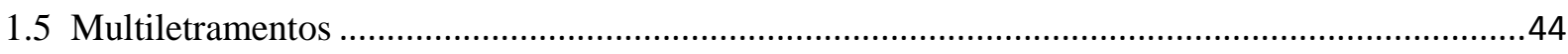

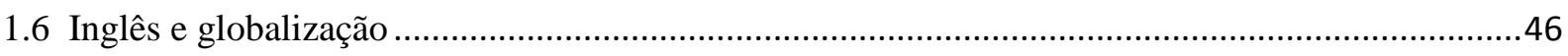

1.7 Perspectivas em Educação de Jovens e Adultos no Brasil .............................................................50

CAPÍTULO 2: DISTANCIAMENTOS ENTRE O LETRAMENTO SOCIAL E O LETRAMENTO ESCOLAR NA LÍNGUA ESTRANGEIRA …......................................... 57

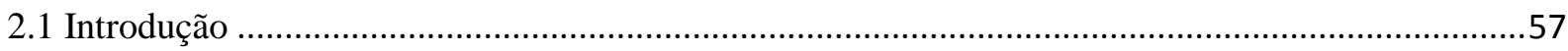

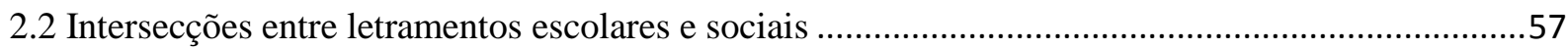

2. 3 Levantamento de expectativas de aprendizagem na EJA.............................................................60

2. 4 Concepções de educação, conhecimento e línguas na exploração de temas norteadores: interdisciplinaridade, transversalidade e transdisciplinaridade ...........................................................63

2.5 Dos eixos temáticos à noção de língua estrangeira como um sistema de vocábulos .......................67

2.5.1 A conscientização sobre a energia, da professora Milena ........................................................68

2.5.2 O desenvolvimento de vocabulário sobre partes do rosto e do corpo, conforme observado nas

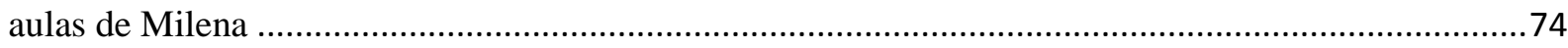

2.5.3 O trabalho com os cômodos de uma casa, nas aulas de Milena ................................................77

2.5.4 O trabalho com questões relacionadas à infância dos estudantes, proposta pela professora Vívian 


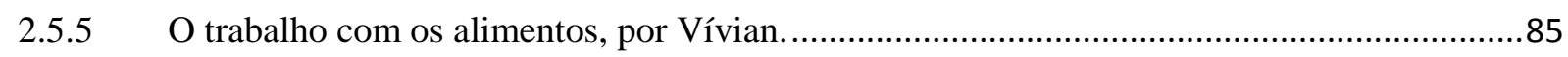

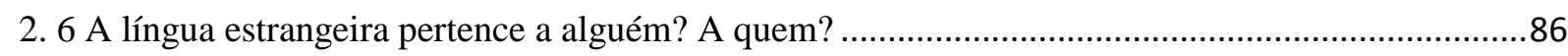

CAPÍTULO 3: APROXIMAÇÕES ENTRE O LETRAMENTO SOCIAL E O LETRAMENTO

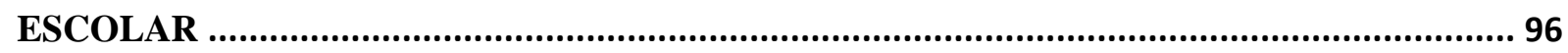

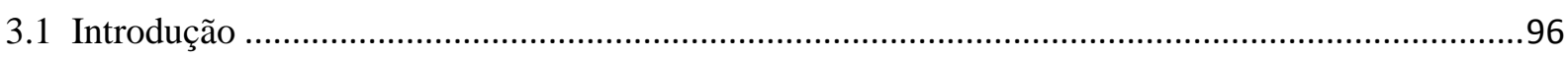

3.2 Textos e contextos: letramentos sociais e a cultura de massas.....................................................96

3.3 Do repertório popular para a sala de aula: a música como possibilidade de aprendizagem em

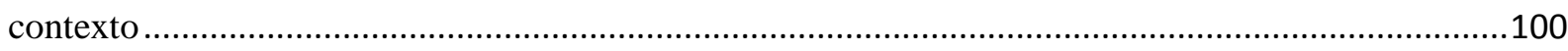

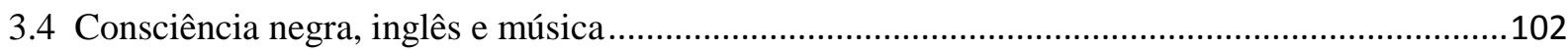

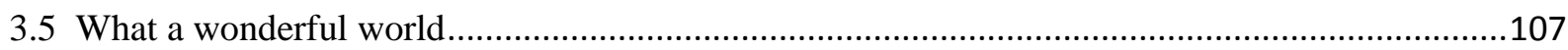

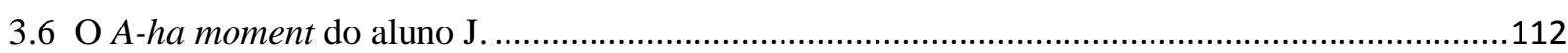

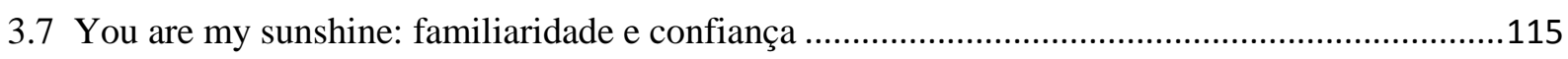

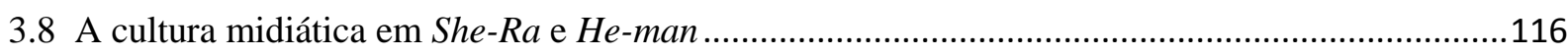

3.9 Reconhecendo e discutindo estrangeirismos no contexto brasileiro ...........................................118

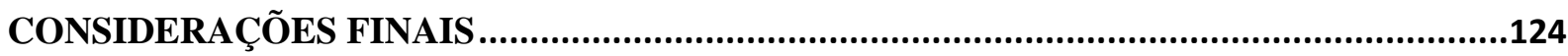

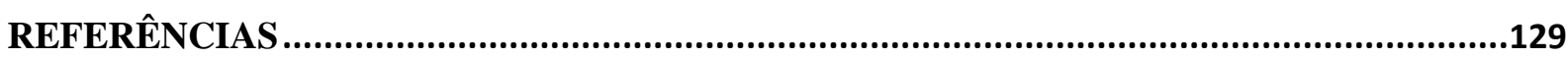

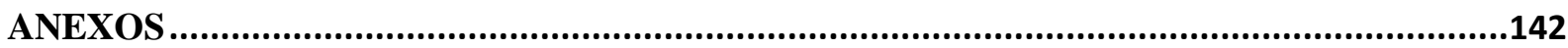

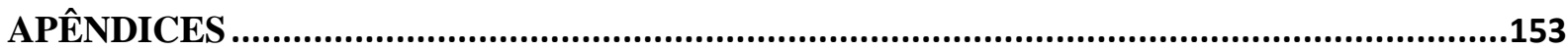




\section{INTRODUÇÃO}

Expondo em ordem cronológica, a inquietação inicial que impulsiona a pesquisa advém da minha história pessoal ${ }^{1}$. Explico-me: tendo completado minha formação educacional inteiramente em instituições públicas, o tema desta pesquisa me interessa pessoalmente, já que vivenciei, de dentro de uma escola pública, as mudanças tecnológicas, sociais e educacionais que dão base às investigações propostas neste trabalho.

Quando ainda era estudante do Ensino Fundamental, na cidade de São Paulo, em meados dos anos 1990, já percebia o discurso recorrente, materializado em piadas infantis entre meus colegas de classe, de que é impossível aprender inglês na escola pública. Ao mesmo tempo, o PC (personal computer) se popularizava no Brasil e com ele, a Internet. Alguns de meus colegas de escola e de bairro, inclusive, mencionavam ter acabado de ganhar um PC. Àquela época, além de estudar inglês na escola regular, eu gostava de ouvir músicas em inglês no rádio. Mais tarde, por volta dos 15 anos de idade, comecei a estudar inglês em uma escola de idiomas próxima à minha casa. As aprendizagens de língua empreendidas tanto na escola regular quanto na de idiomas eram diferentes das letras de música no rádio FM, uma importante motivação para prática de aprendizado da língua. Sem as facilidades da internet, eu comprava, em bancas de jornal, revistas especializadas contendo letras e traduções das músicas das minhas bandas favoritas. Levava essas revistas para a escola e costumava tirar dúvidas com colegas que estudavam inglês - também em escolas de idiomas - há mais tempo do que eu. As bandas de rock, as revistas e o interesse por língua inglesa acabavam por se configurar um mundo compartilhado por nós, adolescentes.

É merecedora de reflexão a suposta construção de identidade mediada por artefatos tecnológicos e símbolos culturais como o rádio e a música em inglês, partindo-se do pressuposto de que essa é de fato uma construção identitária. Trata-se, mais profundamente falando, de uma construção ideológica, deliberadamente produzida, que tem se difundido desde o surgimento da imprensa como um todo, se pensarmos em comunicação e linguagem mediadas por tecnologias de forma mais ampla. Ao considerarmos o rádio e o efeito de outras mídias, como a televisão, podemos identificar que, em meados do século $\mathrm{XX}$, o rádio e a televisão foram grandes aliados de uma unificação nacional na sociedade ocidental. A respeito dessa unificação, Costa (2002) nos lembra sobre o efeito da propaganda nazista, mediada pelo

\footnotetext{
${ }^{1}$ Neste e em outros trechos do texto, utiliza-se a primeira pessoa. Tratam-se de relatos pessoais pertinentes às argumentações e à abordagem da linha de pesquisa empregada nas investigações.
} 
rádio, como forma de buscar o apoio da população ao nazismo ${ }^{2}$. Indo mais adiante nesse pensamento, Costa (idem) pontua que a história do desenvolvimento industrial e do capitalismo na Europa atribuiu ao setor de comunicação e transportes um status elevado e grande força estratégica justamente por esse poder na economia e na ideologia. É por isso que o simples fato de eu ter tido contato com músicas em inglês em estações de rádio brasileiras desde minha infância é que meu interesse por esse tipo de música, ou troca simbólica, pode não ter sido algo tão ingênuo assim, pelo menos não por parte daqueles que se beneficiam desse tipo de reforço ideológico. São inúmeras as escolas de idiomas que usam em suas propagandas imagens de celebridades do cinema, são inúmeros os empreendimentos em torno de eventos internacionais como Copa do Mundo e Olimpíadas no Brasil, etc. Vejo-os como parte de uma máquina de recursos e de bens simbólicos que se mantém desse ideal que é acessar uma língua estrangeira e fazer parte de um grupo privilegiado, conforme critica Kumaravadivelu (2011) ao afirmar que há grandes interesses comerciais na indústria do ensino de inglês na fase de globalização que vivenciamos atualmente. Não é por acaso que Jameson (1998. p. 55 apud KUMARAVADIVELU 2011, p. 131) entende a globalização como um conceito comunicacional, "que alternativamente mascara e transmite significados culturais e econômicos". Para Kumaravadivelu (2011) a comunicação via internet se tornou o motor principal da globalização em sua fase atual, orientando demandas da economia e das identidades culturais e linguísticas. Sem ela, o crescimento econômico e a mudança cultural não teriam ocorrido de forma tão vertiginosamente rápida e surpreendente. Se a internet é o motor da globalização, o inglês é apontado como sua língua e posiciona-se no centro dos estudos de linguística aplicada contemporânea, fato questionado por Kumaravadivelu (2011, p. 131).

A crítica de Kumaravadivelu (2011) sobre o ideário da globalização e da língua inglesa pode ser melhor compreendida se considerarmos que a globalização não é um fenômeno recente e é compreendido de maneiras diferentes por pessoas diferentes em épocas e contextos diferentes (KUMARAVADIVELU 2011). Alguns estudiosos apontam que ela esteve presente em toda a história humana, porém há linhas de pensamento que apontam para três ondas principais de globalização, associadas a três fases do colonialismo/imperialismo da Idade Moderna. A primeira onda de globalização foi centrada nas explorações comerciais lideradas por Espanha e Portugal; a segunda onda é marcada pela industrialização liderada pela Grã-

\footnotetext{
${ }^{2}$ A respeito da Segunda Guerra Mundial, as tecnologias serviram ao propósito de unificação não apenas ao nazismo. Muitos confrontos contaram com a presença de cineastas contratados para registrar imagens que foram veiculadas e utilizadas como propaganda.
} 
Bretanha; a terceira advém do momento pós Segunda Guerra Mundial, do qual os Estados Unidos foram e são notáveis líderes.

$\mathrm{Na}$ atual fase da globalização, há mudanças de paradigmas no que diz respeito à diminuição de distâncias de espaço, tempo e fronteiras. Sendo entendido como um fenômeno comunicacional cuja língua principal é a língua inglesa, a globalização é um importante aporte para a reflexão que se estabelece neste trabalho, uma vez que seus princípios e efeitos se relacionam a questões sócio-históricas, ideológicas e identitárias que muito contribuem para a compreensão do contexto desta pesquisa.

Para Kalantzis e Cope (2012), os seres humanos são criaturas globais por excelência, já que temos pistas de que somos os primeiros seres a ocupar potencialmente todas as partes do mundo. Segundo os autores, a globalização pode ser compreendida tendo como base a construção de sentidos realizada pelos seres humanos e remonta a três períodos da história. O primeiro período decorre do fenômeno nomeado por Kalantzis e Cope (2012) de "primeiras línguas", que podem ser observadas em comunidades e tribos de tradição oral, porém também caracterizadas pela multimodalidade: sinestesia, de gestos, cores e sons, por exemplo, são recursos de significação nessas linguagens. O segundo período de globalização é marcado pelo surgimento da escrita e a consequente tentativa de uniformização e unificação baseadas no estado nação. A escrita surge como uma tentativa de acúmulo de conhecimentos derivados do assentamento territorial com base na agricultura, como a necessidade de se registrar inventários, por exemplo. O terceiro período de globalização ocorre no final do século XX e no começo do século XXI, advindo das transformações nos processos de construção de significados derivados das novas mídias e sua garantia de diversidade. Com um declínio do privilégio da escrita alfabética, retorna-se à diversidade e à multimodalidade.

Retomando essa reflexão sobre minha história, hoje, formada em Letras Português/ Inglês e atuando como professora de língua inglesa há mais de dez anos, percebo a importância das práticas sociais para a aprendizagem de uma língua estrangeira, mais especificamente a língua inglesa. Embora sejam fortes os ditames da globalização e do mercado linguístico (BOURDIEU, 1996), uma vez que é inegável perceber a língua inglesa como um bem desejável, capaz de promover status entre seus falantes, entende-se que a aprendizagem de uma língua estrangeira propicia, ao mesmo tempo, a oportunidade de conhecer a língua do outro - pertencente a um mundo de significados e valores diferentes daqueles que um falante reconhece como seus - e de ressignificar a si próprio, dos significados e valores de sua comunidade sociolinguística, bem como uma reflexão crítica de 
seu posicionamento na sociedade. Sobre isso, Rajagopalan (2003) vai além, ressaltando o processo de ensino-aprendizagem de uma língua estrangeira como parte integrante de um amplo processo de redefinição de identidades, de redefinição cultural. Mais que um instrumento de comunicação, as línguas são expressão de identidade de quem se apropria delas. É por isso que, segundo Rajagopalan (2003, p. 69), quando uma pessoa aprende uma língua estrangeira, ela se redefine como outra pessoa.

No caso específico da língua inglesa no esteio da globalização, a oferta de materiais e as interações mediados pela língua inglesa traduzem-se em espaços de aprendizagem de língua, incluindo o acesso a variadas práticas de leitura de textos chamados "autênticos"3, para além das músicas estrangeiras e revistas que eu consumia na época de minha adolescência. Nos tempos atuais, as oportunidades de utilização da língua inglesa têm se multiplicado exponencialmente com o advento das tecnologias e mídias digitais, como no acesso a jornais, revistas, blogs, fóruns, podcasts, etc. Essa maior disponibilidade de acesso a textos e práticas sociais que envolvem a língua inglesa resulta não apenas em transformações nas relações sociais, mas também em novas relações com a construção do conhecimento e, logo, com os agentes dessa construção. De uma maior oferta de textos e oportunidades de utilização da língua na vida prática de uma parcela significativa da população é que deriva o conceito de letramento social que se discute neste trabalho.

Nos diversos estágios cumpridos na licenciatura e em especial na pesquisa de campo de minha iniciação científica, também da área de novos letramentos, realizada em 2008, presenciei manifestações dessas novas relações, tão diferentes dos meus paradigmas de cultura escolar. De fato, novas noções de autoridade, formas de avaliação e práticas de linguagem são abordados nas salas da aula.

O que me inquieta, a ponto de propor a pesquisa em questão, é o efeito dessas mudanças diante do que aparentemente não mudou: o discurso da impossibilidade de aprender inglês nas escolas públicas brasileiras, pauta que permanece nas discussões em diversas esferas da sociedade, dentro e fora da academia ${ }^{4}$.

\footnotetext{
${ }^{3}$ Refiro-me aos textos em contraposição àqueles elaborados especificamente para fins didáticos, muitos deles artificialmente graduados. Essa graduação pressupõe níveis de dificuldade na língua e gera textos "nãoautênticos", como aqueles construídos apenas com verbos no passado, por exemplo.

4 Um frutífero estudo, organizado por Lima (2011), reúne pesquisadores que analisam a narrativa de aprendizagem de um professor de inglês, ex-aluno de escolas públicas, que não aprendeu inglês em sua formação na educação básica. Cf. LIMA, D. C. (org.) Inglês em escolas públicas não funciona? Uma questão, múltiplos olhares. São Paulo: Parábola Editorial, 2011.

Outro trabalho que se debruça sobre a questão foi produzido por Uechi (2006), ao investigar, em cinco escolas de ensino fundamental e médio (duas públicas e três particulares), as demandas e o tratamento "diferenciado" dispensado à disciplina de língua inglesa, advindo da interpretação de que essa é uma disciplina-problema. Cf.
} 
Quando pensamos na modalidade Educação de Jovens e Adultos, doravante EJA, a questão se direciona para um caminho ainda mais complicado e delicado no que diz respeito às possiblidades e impossibilidades de sucesso no ensino e aprendizagem de língua inglesa tendo em vista as premências da contemporaneidade. Embora se reconheça que a língua inglesa tenha alcançado a cotidianidade de uma parcela cada vez maior da população mundial, o perfil do alunado de EJA está inserido em um histórico de marginalização social e econômica , o que envolve também a negação aos recursos simbólicos produzidos também nesta língua. Ocultando essas relações de inclusão e exclusão, podemos citar o fator etário, geralmente visto como um impeditivo para a aprendizagem de língua estrangeira. Outro elemento frequentemente citado nesse sentido é o discurso de que aprender língua estrangeira é tarefa para quem tem tempo e dinheiro, o que o aluno de EJA aparentemente não tem. Refutando tal discurso, temos crítica de Bourdieu (1998), segundo o qual o tempo e o dinheiro "investidos" na aprendizagem e no uso da língua, assim como outros símbolos que conferem status entre as pessoas, equivalem a capitais de distinção entre grupos sociais. Isto é, o uso da língua revela e acentua diferenças sociais. Assim, ter acesso ou não a um determinado uso de língua, seja ele em língua materna ou em língua estrangeira, revela diferenças sociais instauradas por relações de poder.

\section{Objetivos gerais}

A respeito dessas inquietações, propomo-nos a realizar uma investigação interpretativa acerca das relações sociais, pedagógicas e escolares representados em duas comunidades investigadas. A questão da interpretação das representações se aproxima das propostas dos novos letramentos e multiletramentos, uma vez que tais estudos dão conta das novas concepções e práticas de linguagem e leitura, relações de ensino e aprendizagem e práticas pedagógicas em um mundo que muda constantemente e se torna cada vez mais digital e globalizado. De acordo com Monte Mór e Menezes de Souza (2006) nas Orientações Curriculares para o Ensino Médio (OCEM-LE), publicação oficial do Ministério da Educação (MEC) que introduziu as noções de novos letramentos para o ensino de língua estrangeira no Brasil, as propostas pedagógicas dos novos letramentos reforçam que a prática de letramento,

UECHI, S.A. Inglês: disciplina-problema nos níveis fundamental e médio? Dissertação (Mestrado em Estudos Linguísticos e Literários) - Faculdade de Filosofia, Letras e Ciências Humanas, Universidade de São Paulo, São Paulo, 2006.. 
sendo uma prática social, interage com novos insumos, o que pode gerar transformações de forma crítica e eficaz.

Os autores acrescentam ainda que, tendo em vista que o conhecimento é social e culturalmente contextualizado, os novos conhecimentos se inter-relacionam com os conhecimentos já existentes, resultando em uma transformação de ambos, "novos" e "velhos", que leva à criação de algo novo. Da mesma forma, como consequência das transformações geradas pelas inter-relações de "novos" e "velhos" conhecimentos, o próprio contexto da prática social se transforma. Refletindo e interpretando criticamente esse processo, percebe-se que ele é uma constante. Isso nos permite afirmar que linguagem, cultura e conhecimento são conjuntos abertos a recontextualizações e transformações constantes (MONTE MÓR e SOUZA, 2006).

Com tais concepções adjacentes às propostas de novos letramentos e multiletramentos, a pesquisa pressupõe que linguagem, cultura e conhecimento, longe de serem dados fechados e estanques, demandam, em seus múltiplos sentidos, nossa interpretação. Tal pressuposto é notado nos estudos hermenêuticos como os de Ricoeur (1977), que discute a linguagem como um instrumento cultural de apreensão da realidade, reforçando que a expressividade do mundo surge na linguagem através do símbolo como múltiplo sentido, e que, portanto, deve ser interpretado. Deriva também dos estudos hermenêuticos a concepção de que tudo o que se interpreta, se interpreta de um lugar. Trata-se da consideração de que as interpretações não são apenas buscas a uma essência da verdade única e que deveria ser encontrada nas entrelinhas dos textos, como de fato pensaram os hermenêuticos tradicionais praticantes da exegese bíblica. Interpreta-se de um lugar com os recursos simbólicos e culturais disponíveis em dado momento histórico. Desse modo, as intepretações são significações compartilhadas e baseadas em culturas, comunidades e grupos que possuem práticas sociais e linguísticas em comum (THOMPSON, 1998). Daí a importância de se posicionar nesse ato de intepretação, pois nenhuma interpretação é neutra, asserção que também se aplica a um texto acadêmico como este, cuja recomendação de escritura convencional preza pela neutralidade. Porém, nas premissas da hermenêutica crítica, essa dada neutralidade não existiria nas ciências.

Quanto a essa neutralidade, Boaventura de Souza Santos (1988) nos informa que as ciências naturais são, elas mesmas, definidas e administradas por pessoas em seus determinados contextos. De acordo com o autor, esse paradigma de neutralidade nas ciências naturais passou a ser revisto diante de variados fatores, a começar pelos postulados da teoria da relatividade de Albert Einsten, segundo o qual a definição de simultaneidade de eventos 
ocorridos em longas distâncias só pode ser dada por aquele que os observa. Outro fator a ser considerado é o fenômeno da industrialização das ciências naturais, ocorrido no século XX, que evidenciou o comprometimento dessas com centros de poder político e econômico. Ainda segundo Boaventura de Sousa Santos (idem), a dicotomia entre ciências humanas, avaliadas como subjetivas, e as ciências naturais, ditas objetivas, é uma questão a ser superada para uma prática pós-moderna nas ciências.

Levando em conta essas asserções, este trabalho realizou uma pesquisa qualitativainterpretativa, seguindo as noções acima discutidas sobre interpretação e recorrendo a procedimentos associados à etnografia. A escolha dessa metodologia justifica-se por promover a busca de significados de ações ocorridas em uma comunidade escolar determinada, o que explica sua maior recorrência em pesquisas voltadas para a educação. Geertz (1973) esclarece que “a descrição etnográfica é microscópica”; sendo assim, fundamentamos a pesquisa na investigação e na interpretação crítica de duas comunidades específicas, onde ocorre a interação entre a pesquisadora e os colaboradores em trabalho de campo para a coleta de dados pedagógicos e sociais relativos a esses universos, sem a finalidade de estabelecer parâmetros generalizadores para todo o contexto educacional.

Nessa abordagem, observa-se participativamente as comunidades investigadas, lançando-se mão de instrumentos de registro de dados, como anotações no diário de campo, questionários e gravações de entrevistas semiestruturadas. A interpretação dos dados constitui-se uma tentativa de entendimento da lógica que rege as práticas pedagógicas de determinada comunidade escolar, observando-lhe os valores, hábitos, comportamentos e ações dos sujeitos nela envolvidos (DUBOC, 2007).

Para triangulação dos dados, a coleta de informações teve por instrumentos, além da observação participativa de aulas e do ambiente escolar com anotações em diário de campo, a aplicação de questionários escritos e a realização de entrevistas semiestruturadas com professores e alunos colaboradores. Dessa maneira, com os dados coletados e o apoio teórico, procedemos a uma interpretação crítica sob o ponto de vista dos estudos de novos letramentos e multiletramentos.

\section{Objetivos específicos}

Tendo em vista que alunos da modalidade EJA em geral têm em sua trajetória de vida um amplo repertório de aprendizagens ocorridas fora do contexto escolar, a presente pesquisa 
teve por objetivo compreender, sob a perspectiva das teorias dos novos letramentos e multiletramentos, as práticas de aprendizagem de língua inglesa manifestadas em contextos que independem da escolarização em relação com as práticas escolares a que os alunos estão se habituando. Em uma sociedade cada vez mais digital, globalizada e em constantes transformações sociais, econômicas e tecnológicas, as oportunidades de aprendizagem, independentemente de qual seja o conteúdo, surgem praticamente a todo momento, em qualquer lugar, por parte de qualquer pessoa (KALANTZIS; COPE, 2010).

A pesquisa buscou investigar as relações entre práticas sociais e de aprendizagem empreendidas por alunos de EJA e suas implicações para a aprendizagem escolar, especialmente no que se refere às práticas de linguagem mediadas pelo uso de novas tecnologias. Essa investigação ocorre no contexto de duas comunidades escolares de ensino público na modalidade EJA. A interpretação das conceituações realizadas pelos colaboradores sobre suas práticas de linguagem e de aprendizagem dentro e fora do contexto escolar norteia as análises que nos permite pensar tais contextos sob o ponto de vista dos estudos de novos letramentos e multiletramentos.

A investigação ocorreu em um grupo específico de alunos de duas comunidades escolares da rede pública e busca responder às seguintes perguntas:

1) Os conhecimentos construídos em práticas escolares se relacionam com os conhecimentos construídos ao longo da trajetória dos estudantes? Em caso positivo, como essa relação é visualizada nas aulas? Em caso negativo, que leitura é possível fazer dessa desconexão?

2) Que entendimento têm professoras e estudantes de EJA sobre a relação entre as práticas de letramento escolar e as práticas de letramento social?

\section{Comunidades investigadas}

A coleta de dados ocorreu em duas escolas da rede pública municipal da cidade de São Paulo entre setembro e dezembro de 2012. As duas escolas se localizam em bairros periféricos da cidade, uma na Zona Leste e a outra na Zona Sul. Os nomes dessas escolas foram substituídos por nomes fictícios a fim de preservar-lhes as identidades. Com o mesmo objetivo, os nomes das professoras e dos alunos colaboradores também foram substituídos, bem como os de outras pessoas mencionadas em suas falas. Letras seguidas de números foram 
utilizadas para caracterizar os alunos em substituição a seus nomes. Bairros, lugares, empresas e demais menções que pudessem, de alguma forma, identificar os participantes também foram substituídos por letras, como A., ou B., nas transcrições de entrevistas e questionários.

Segue o resumo das comunidades que compuseram esta pesquisa:

\begin{tabular}{|c|c|c|c|c|c|c|}
\hline & Escola & Turma & $\begin{array}{l}\text { Código da } \\
\text { turma }\end{array}$ & Período & Professora & $\begin{array}{c}\text { Alunos } \\
\text { participantes }\end{array}$ \\
\hline \multirow{6}{*}{ 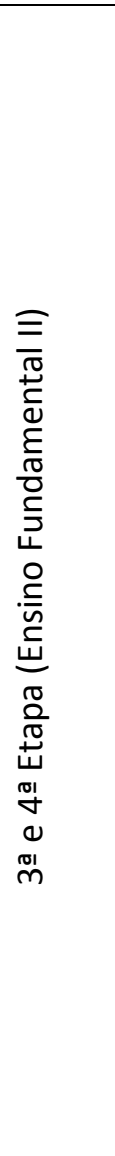 } & $\begin{array}{c}\text { Centro } \\
\text { Educacional } \\
\text { Trandisciplinar }\end{array}$ & 3 Módulo A & $A$ & Manhã & Vívian & 10 \\
\hline & $\begin{array}{c}\text { Centro } \\
\text { Educacional } \\
\text { Trandisciplinar }\end{array}$ & 3 Módulo D & $B$ & Manhã & Vívian & 9 \\
\hline & $\begin{array}{c}\text { Escola } \\
\text { Municipal } \\
\text { Paulo Freire }\end{array}$ & 3a Etapa A & C & Noite & Milena & 26 \\
\hline & $\begin{array}{c}\text { Escola } \\
\text { Municipal } \\
\text { Paulo Freire }\end{array}$ & 3a Etapa B & $\mathrm{D}$ & Noite & Milena & 8 \\
\hline & $\begin{array}{c}\text { Escola } \\
\text { Municipal } \\
\text { Paulo Freire }\end{array}$ & 4a Etapa A & $E$ & Noite & Milena & 13 \\
\hline & $\begin{array}{c}\text { Escola } \\
\text { Municipal } \\
\text { Paulo Freire }\end{array}$ & 4a Etapa B & $F$ & Noite & Milena & 11 \\
\hline Total & & & & & & 77 \\
\hline
\end{tabular}

Tabela 1 - Aulas observadas 


\section{Vívian, professora de Linguagens e Códigos no Centro Educacional Transdisciplinar}

A escolha de Vívian como uma das participantes desta pesquisa foi orientada por sua frequência aos encontros de formação continuada oferecidos pela Prefeitura Municipal de São Paulo em 2010 na área de novos letramentos e multiletramentos em língua estrangeira, do qual resultou o Caderno de Orientações Didáticas para EJA - Língua Estrangeira - Inglês, publicado em 2010. Em contato com a Secretaria Municipal de Educação (SME), solicitei a indicação de uma professora que pudesse colaborar em minha pesquisa e obtive a nomeação de Vívian por lecionar em uma escola relativamente próxima à minha residência. Tendo recebido as devidas orientações da SME sobre os procedimentos necessários para a efetivação da pesquisa, tais como a apresentação do projeto e as autorizações da coleta de depoimentos, contatei a escola onde Vívian trabalha e me certifiquei de que poderia conversar com a coordenação para pedir autorização às observações. Fui prontamente recebida tanto pela coordenadora Débora ${ }^{5}$, que embora estivesse bastante atarefada quando visitei a escola pela primeira vez, apresentou-me a rotina e os horários do estabelecimento para que eu fizesse boas escolhas na observação das aulas. Além disso, a coordenadora autorizou a saída da professora Vívian de sala de aula por alguns minutos para conversar comigo, pois, na ocasião, ela estava lecionando. Vívian também foi bastante receptiva, sugerindo turmas cujos horários eram adequados à minha disponibilidade.

Bacharel e licenciada em Letras Português-Inglês por uma universidade particular da cidade de São Paulo, Vívian possuía, à época da coleta de dados, dezessete anos de experiência como professora de língua inglesa em escolas particulares e públicas, dos quais dez tinham sido dedicados ao trabalho em escolas da prefeitura de São Paulo. Sua atuação em Educação de Jovens e Adultos teve início no mesmo ano em que ingressou na rede de ensino da prefeitura dessa mesma cidade, em 2001. A professora integrava o Centro Transdisciplinar desde o ano de 2009, tendo sido aprovada, no ano anterior, em um processo seletivo especialmente designado para a contratação de professores efetivos da rede municipal para docência nos centros especializados em Educação de Jovens e Adultos. Extremamente concorrido, o mencionado processo é composto por prova escrita focada em conhecimentos sobre a modalidade EJA e suas especificidades, entrevista com diretor regional, apresentação

\footnotetext{
${ }^{5}$ Nome fictício a fim de preservar a identidade da profissional.
} 
de um projeto e/ou proposta de trabalho que ilustre o trabalho do docente, além da exigência de pelo menos dois anos de docência em Educação de Jovens e Adultos.

\section{Centro Educacional Transdisciplinar ${ }^{6}$}

A primeira escola observada é um centro educacional criado por meio do decreto 43.052 de 04/03/2003, portaria 3006 de 18/05/2004, destinado à exclusiva oferta de EJA. Resulta de um processo avaliativo pelo qual passaram os antigos Centro Municipal de Ensino Supletivo (CEMES), surgidos em 1993, que verificou resultados e demandas específicas dessa modalidade de ensino em 2001. O objetivo desses centros é oferecer, em bairros com maior demanda dessa modalidade de ensino, baseando-se em formas adequadas de ensinar e aprender neste público, educação básica e educação profissional (Lei n 11741 de 2008) em um espaço onde se articulam convívio, cultura, lazer e discussões sobre o mundo do trabalho. Promove também um espaço coletivo e permanente de formação dos educadores que neles atuam.

A escola possui currículo integrado ${ }^{7}$, carga horária flexibilizada ${ }^{8}$ e horários de aula diferenciados ${ }^{9}$ em relação às demais escolas regulares. Tais estruturas têm por objetivo melhor atender as demandas do aluno de EJA, que em geral concilia os estudos a compromissos diversos, como afazeres domésticos, cuidado com a família e longa jornada de trabalho. Um exemplo do benefício dessas estruturas diferenciadas aos alunos em oposição à oferta de ensino de EJA das escolas regulares pode ser observado com relação aos alunos que

\footnotetext{
${ }^{6}$ Os nomes das duas escolas, das professoras e de todos os profissionais colaboradores nesta pesquisa foram substituídos para preservar-lhes a identidade. Os bairros em que se localizam as escolas também não serão mencionados, embora sejam uma importante fonte de informação a respeito do contexto.

${ }^{7}$ Diferentemente da maioria das escolas regulares, o currículo não é organizado por disciplinas, mas por áreas de conhecimento mais abrangentes: Ciências Humanas, Ciências Exatas, Linguagens e Códigos - cujas aulas foram observadas - , Ensino Profissionalizante (informática). Os professores atuam articuladamente e participam de reuniões semanais de preparo e organização de conteúdos e materiais pedagógicos. Avaliações, oficiais ou não, também são planejadas nessas reuniões, em que há oportunidade de revisão por parte de professores de outras áreas, por exemplo. Sobre isso, Pennycook (2006) afirma que "as disciplinas não são estáticas, domínios demarcados de conhecimento aos quais pedimos emprestados construtos teóricos, mas são elas mesmas domínios dinâmicos de conhecimento (PENNYCOOK 2006, p. 72)"

${ }^{8}$ Composta por uma porcentagem de aulas presenciais articulada a atividades a serem cumpridas pelos alunos fora da sala de aula.

${ }^{9}$ A escola funciona em quatro turnos de $2 \mathrm{~h} 15$ cada: das $7 \mathrm{~h} 15$ às $9 \mathrm{~h} 30$, das $9 \mathrm{~h} 45$ às $12 \mathrm{~h}$, das $17 \mathrm{~h} 45$ às $20 \mathrm{~h}$ e das $20 \mathrm{~h} 15$ às $22 \mathrm{~h} 30$.
} 
trabalham no turno da noite, pois é sabido que essa modalidade de ensino em geral se concentra no período noturno nas escolas regulares.

Atualmente, existem 14 (catorze) $\operatorname{centros}^{10}$ desse tipo em São Paulo e cada escola conta com seu próprio Projeto Político Pedagógico (PPP).

A escola localiza-se num bairro de periferia na Zona Leste de São Paulo e conta com uma equipe de 24 educadores. Um dado importante sobre esse bairro, presente no PPP, é que 97\% de sua população trabalha em outros bairros, caracterizando-o como um bairrodormitório. Uma contradição é que este bairro foi palco, em 1926, da construção de uma ferrovia, porém hoje a principal atividade do bairro é o comércio e serviços. O bairro fica próximo a uma rodovia, ao aeroporto Internacional de Cumbica, cidade de Guarulhos, e ao campus de uma universidade estadual.

A escola funciona em um prédio onde já funcionou um CEMES. Aparenta ser uma grande casa, adaptada para o recebimento dos alunos. O portão de entrada do prédio é desenhado com grafite colorido com o nome da escola. A parede lateral também é desenhada com grafite que remete a um espaço educacional, pois apresenta a figura estilizada de um formando, com beca, capelo e braços erguidos comemorando à frente de uma rua com carros e ônibus coletivos trafegando. A secretaria da escola pode ser vista da calçada, onde ficam, próximas ao balcão, as pessoas que aguardam por atendimento. Na minha primeira visita à escola, em setembro, chovia muito e havia duas pessoas na fila, perguntando pelos procedimentos de matrícula. Praticamente, todas as vezes em que estive na secretaria presenciei pessoas procurando por vagas, deixando seus nomes em listas de espera.

A escola conta com 10 (dez) salas de aula significativamente pequenas, distribuídas em quatro andares, sendo um deles no subsolo, abaixo do nível da rua. O subsolo, cujo acesso se dá por elevador ou por uma larga rampa que começa na calçada da rua, é reservado para as aulas de Ensino Fundamental I e tem 4 (quatro) salas, 2 (dois) banheiros, bebedouros, e um pequeno pátio onde se distribui o lanche (em geral, leite achocolatado e biscoitos doces ou salgados, no horário da manhã) aos alunos. No andar térreo fica a secretaria, a sala dos professores, conectada a uma cozinha reservada aos funcionários da escola, a sala da coordenação e banheiros. No primeiro andar, onde se pode chegar através de escada ou elevador, ficam as salas de aula do Ensino Fundamental II. Lá há cerca de 5 (cinco) salas separadas por um grande corredor, onde há banheiros e bebedouros também. No corredor há um mural com fotos e colagens de trabalhos temáticos realizados pelos alunos. Nos três meses

\footnotetext{
${ }^{10}$ Informação extraída do site da Secretaria Municipal de Educação da prefeitura de São Paulo, disponível em http://portalsme.prefeitura.sp.gov.br. Acesso em 27 julho 2014.
} 
de observação, foram expostos trabalhos com fotografias e frases sobre animais e, sob a orientação da professora colaboradora, uma exposição de trabalhos de Linguagens e Códigos cujo tema era Paul Cézanne, com uma cesta de frutas pintadas com lápis de cor e tintas em sala de aula. O segundo andar, que também tem acesso por elevador ou escada, abriga a sala de informática, equipada com aproximadamente 16 (dezesseis) computadores, e o espaço de convivência e leitura. Esse espaço se organiza em basicamente duas partes: a parede do lado direito tem uma estante de livros, com mesas redondas com cadeiras próximas, do lado esquerdo, há cadeiras enfileiradas formando uma plateia. Neste espaço, foram expostos os trabalhos manuais celebrando o Dia das Crianças e onde, no mesmo dia, os alunos foram convidados a participar de brincadeiras de roda com cantigas e a manipular os brinquedos produzidos pelos colegas e que estavam em exposição. No mesmo andar ficam guardados, atrás de um portão, alguns instrumentos da escola, como bateria e teclado. É importante destacar o uso desses elevadores pelos alunos cadeirantes e idosos atendidos pela escola, bem como aqueles que possuem algum tipo de necessidade especial.

Cada sala de aula conta com no máximo 20 (vinte) carteiras, organizadas em fileiras, limpas e aparentemente novas e bem conservadas. Em algumas salas do Ensino Fundamental II há duas lousas, uma à frente das carteiras e outra na lateral. Essa lousa da lateral era, em geral, utilizada pela professora para anotar avisos e lembretes, como tarefas para casa e materiais a serem trazidos nas próximas aulas. Nas paredes das salas de aula havia a exposição de trabalhos de alunos. Na sala do $3^{\circ}$ Módulo ${ }^{11}$ sempre me chamavam a atenção duas exposições, uma orientada pelos professores de Linguagens e Códigos e outra pela equipe de Ciências Humanas. A primeira trazia o tema mãos: em folhas sulfite, as mãos dos estudantes estavam delineadas com canetas coloridas, junto com dizeres aparentemente criados por eles, porém coletados, com palavras e letras recortadas de revistas; os dizeres tinham relação com mãos e revelava a vida dos alunos, tais como "Mãos de trabalhador", "Mãos de costureira", "Segura na mão de Deus, pois ela te sustentará", "Casa totalmente limpa por mãos vitoriosas", "Mão que acaricia os meus filhos". A segunda exposição estava posicionada no fundo da sala, e tinha como tema a Globalização. Dispostas em papel pardo, embalagens de produtos diversos remontavam ao mapa-múndi. Chamou a atenção o fato de não haver produtos do continente africano no trabalho.

De acordo com o PPP do centro educacional participante, a EJA destina-se àqueles que não tiveram acesso ou continuidade de estudos na educação básica na idade apropriada. Não

\footnotetext{
${ }^{11}$ Equivalente à $5^{\mathrm{a}}$ e $6^{\mathrm{a}}$ série do Ensino Fundamental.
} 
se trata de preenchimento de lacunas e conteúdos, ou de assumir um papel compensatório de perdas ou ausências. Contempla a pluralidade, diversidade de regiões e diferentes extratos sociais e a rica cultura baseada na oralidade, porém articula-os aos desafios e as transformações sociais decorrentes da globalização.

\section{Milena, professora de língua inglesa na Escola Municipal Paulo Freire}

A escolha de Milena, professora participante desta pesquisa, obedeceu à regra do "quase acaso": diante de minha previsão de possíveis dificuldades de negociação com a SME para obter indicações de docentes para participar da pesquisa, considerei ser melhor antecipar entre meus contatos algum professor que se interessasse em colaborar. Como fruto de um trabalho que acabara de realizar, no ano de 2012, quando integrei o Projeto "Teaching English to Young Learners", tive significativo contato com alguns docentes da rede pública do município de São Paulo. No mencionado projeto, ministrei oficinas práticas de formação para professores de Inglês que haviam acabado de ingressar na modalidade Ensino Fundamental I, implementada naquele mesmo ano de 2012. Entretanto, não obtive colaborações para a pesquisa dentre esses professores, pois muitos deles haviam optado por lecionar apenas no Ensino Fundamental I à época.

Apesar de nunca efetivamente ter conversado com Milena até a ocasião, nós fomos colegas de bacharelado e licenciatura em Letras Português-Inglês na Universidade de São Paulo ${ }^{12}$. Durante as semanas em que aguardava a resposta da SME para a minha solicitação de um professor participante da pesquisa, encontrei Milena por acaso num seminário direcionado para a discussão de práticas de ensino de língua inglesa, onde nos reconhecemos e conversamos sobre nossa situação profissional. Naquele momento, percebi na incrível coincidência em Milena mencionar estar gostando muito das aulas de EJA na prefeitura de São Paulo um convite para participar da pesquisa, ao qual ela aceitou de pronto. Qual não foi a minha surpresa, pois poucos dias depois do convite que fiz a Milena, a SME indicou-me

\footnotetext{
${ }^{12}$ A formação de turma no curso de Letras não ocorreu no meu caso, o que Paulo Guiraldelli (2003) justifica como a estratégia da departamentalização dos cursos de licenciatura para que estudantes se formem por cumprimento de créditos, não por formação em turmas. Guiraldelli (idem) explica que essa foi uma investida, mantida até os dias de hoje, dos militares contra uma possível articulação dos estudantes dos cursos de licenciatura, futuros professores, contra as imposições ditatoriais do governo.
} 
Vívian. Porém, ao perceber que já havia feito o convite à professora Milena e que ela se manifestara de forma muito acolhedora e positiva, vi uma oportunidade de ampliar minha perspectiva e fazer uma dupla observação.

À época da coleta dos dados, Milena cursava, em uma instituição particular, a sua segunda pós-graduação, voltada para práticas de ensino de Inglês subsidiadas pelas novas tecnologias. Em sua primeira pós-graduação, ocorrida em 2011, também em uma instituição privada, estudou formação docente para o ensino superior, por ter como objetivo lecionar nessa modalidade no futuro. Além de ter atuado em escolas de idiomas e em escolas regulares da rede particular, Milena contava com três anos de experiência, como professora de língua inglesa, o que inclui aulas na EJA, na rede municipal de ensino de São Paulo.

\section{Escola Municipal Paulo Freire ${ }^{13}$}

A Escola Municipal Paulo Freire oferta Ensino Fundamental I e II aos seus mais de 900 (novecentos) alunos matriculados e conta com 84 (oitenta e quatro) educadores. A modalidade EJA é oferecida a mais de 200 (duzentos) alunos no período noturno e conta com 70 (setenta) vagas para o EF I - 35 (trinta e cinco) para a $1^{\text {a }}$ Etapa, 35 (trinta e cinco) para a $2^{\text {a }}$ Etapa - e 180 (cento e oitenta) vagas para o EF II - 45 (quarenta e cinco) para a $3^{\text {a Etapa, }}$ onde as observações se concentraram, e 135 (cento e trinta e cinco) para a ${ }^{\mathrm{a}}$ Etapa. Em 2012, a escola possuía 2 (duas) turmas de $3^{\text {a }}$ Etapa e 2 (duas) de $4^{\text {a }}$ Etapa, cujas aulas foram observadas.

Localiza-se num distrito da Zona Sul da cidade de São Paulo, em um bairro planejado e construído, na metade do século XX, por uma empresa ligada a construção de estradas, com $\mathrm{o}$ intuito de atender à demanda de moradia dos trabalhadores funcionários da mesma ${ }^{14} \mathrm{O}$ bairro onde a escola se localiza se posiciona em uma área de mananciais, próxima a duas represas e ao autódromo da cidade, que recebe corridas de carros. Vale ressaltar que a proximidade entre a escola e o autódromo, que atrai espectadores de diversos países, por vezes é valorizada pela professora Milena por proporcionar uma possibilidade de comunicação com falantes estrangeiros.

\footnotetext{
${ }^{13}$ Os nomes das duas escolas, das professoras e de todos os profissionais colaboradores nesta pesquisa foram substituídos para preservar-lhes a identidade. Os bairros em que se localizam as escolas também não serão mencionados, embora sejam uma importante fonte de informação a respeito do contexto.

${ }^{14}$ Fonte: Wikipedia.
} 
Fundada em 2002 com o intuito de amenizar os problemas de superlotação das escolas da região, a escola atende a populações moradoras de bairros mais periféricos do entorno, descendentes diretos e indiretos de famílias oriundas da região Norte, Nordeste e Minas Gerais, que migraram para São Paulo entre 1970 e 1990 em busca de melhores oportunidades de emprego na indústria, de acordo com o PPP. Entretanto, ainda segundo o mencionado documento, as mudanças estruturais da cidade de São Paulo, que de potência industrial passou a concentrar o setor de prestação de serviços, deixaram vulneráveis esses habitantes, que passaram a ocupar de forma irregular as reservas de áreas públicas e mananciais. O PPP aponta um grande número de alunos residentes em moradias irregulares. Menciona-se, inclusive, uma pesquisa em que se verificou alto índice de vivência de violência no dia a dia dos alunos atendidos, correspondendo entre 10 a 15\% dos alunos. O PPP aborda a questão da violência como uma constante no cotidiano escolar. Entretanto, acredito que esse fator tenha sido observado entre os alunos do ensino regular, já que entre a modalidade EJA não notei qualquer indício de conflitos. Pelo contrário, Milena me apontou a alguns alunos, mais jovens que os demais participantes desta pesquisa, que foram convidados a frequentar a modalidade EJA devido a problemas de indisciplina quando pertenciam ao ensino regular, o que, na perspectiva da professora, foi um ganho, pois os alunos passaram a se comportar mais afetivamente - e adequadamente, da perspectiva da professora - com os colegas e professores $^{15}$.

A escola possui 15 (quinze) salas de aula grandes, equipadas com aproximadamente 40 (quarenta) carteiras cada. Em seus três andares, há brinquedoteca, elevador, sala de informática, quadra e sala de leitura. No andar térreo ficam o pátio e refeitório, onde é servido o jantar aos alunos de EJA. Próximo ao portão para alunos, há um banner onde se anunciam as aulas de EJA, com os dizeres "Pare, pense e decida, a Escola Municipal Paulo Freire vai melhorar sua vida. Faça já sua matrícula para EJA 2013 - Fone xxxx-xxxx”. Passado o portão

\footnotetext{
${ }^{15} \mathrm{O}$ processo de juvenilização da EJA, isto é, a migração de alunos adolescentes em idade apropriada ao ensino fundamental regular para a modalidade EJA tem aumentado significativamente nos últimos anos, o que tem gerado debates, segundo relatório de pesquisa da ONG Ação Educativa, encomendada pelo Instituto Nacional de Estudos e Pesquisas Educacionais Anísio Teixeira (INEP). De acordo com o referido estudo, o processo iniciouse a partir da redução da idade mínima de 18 (dezoito) para 15 (quinze) anos como critério para matrícula e exames de certificação na EJA e sinaliza um retrocesso de conquistas nessa modalidade, uma vez que traz de volta a visão equivocada de que o propósito da EJA é proporcionar o "aligeiramento" da formação escolar, especialmente entre as populações mais vulneráveis socialmente. Além disso, pode ser entendido como uma diminuição da responsabilidade do poder público de oferecer a esses adolescentes um ensino regular de qualidade. Cf. CATELLI JR, R.; HADDAD, S.; RIBEIRO, V. M. (Orgs.) Educação de Jovens e Adultos: insumos, processos e resultados. São Paulo: Ação Educativa, 2014. Disponível em < http://www.acaoeducativa.org/images/stories/pdfs/relatorio_final_INEP_EJA.pdf > Acesso em 30 novembro 2014.
} 
de ferro, a parede da direita exibe um mural de fotos de um evento dos alunos da EJA. Dentre essas fotos reconhecem-se diversos alunos que foram colaboradores nesta pesquisa. A professora Milena também está em algumas fotos, abraçada aos alunos. Neste pátio há banheiros e bebedouros. Do lado esquerdo do pátio, passando-se por uma grade divisória, tem-se acesso à sala dos professores e da coordenação. De frente para a sala dos professores há o acesso à secretaria e à sala de reuniões, ao lado da cozinha e dos banheiros para os funcionários da escola. Para receber atendimento da secretaria, deve-se passar pelo portão de entrada da rua e dar a volta por fora da escola: há uma espécie de janela de onde pode-se ver os secretários. Do lado direito do pátio há escadas que dão acesso às salas de aula do primeiro andar. Neste andar há 8 (oito) salas de aula, banheiros e bebedouros e é onde todas as turmas da professora Milena tinham aula. No segundo andar há mais salas de aula, porém elas não são todas utilizadas no horário noturno. Neste andar fica o laboratório de informática. Todas as portas das salas de aula são sinalizadas com os nomes das turmas que as dividem, nos períodos da manhã, da tarde e da noite. A porta da sala de informática contém avisos, junto à imagem de uma garota sorridente, para que os alunos não usem o celular e não consumam alimentos na sala. A sala contém cerca de 25 (vinte e cinco) computadores, porém há 3 (três) desligados.

As salas de aula da Escola Municipal Paulo Freire são relativamente grandes, comportam cerca de 40 (quarenta) alunos. Suas carteiras, geralmente organizadas em fileiras ${ }^{16}$, contém rabiscos a lápis, caneta e corretivo líquido, provavelmente produzidos pelos próprios alunos. Há duas lousas nas salas, uma de frente para as carteiras e uma lateral. Essa lousa lateral em geral estava preenchida pelos próprios alunos, provavelmente dos outros períodos, com nomes, apelidos, desenhos e trechos de letras de música, algumas delas em Inglês. Alguns dizeres: "Ricardo + Vanessa ${ }^{17}$ S2", "Karen S2" de onde se puxava uma flecha com a sentença, em letra pertencente a outra pessoa, "Nega do suvaco cabeludo", "Não é só usar preto, é usar o cérebro", "Funk funk funk", "Bring me the horizon". Em algumas salas, sobre essa lousa lateral havia também a exposição de trabalhos dos alunos dos outros períodos. Algumas salas também contavam com banners contendo a tabuada, o alfabeto e o silabário, com imagens ilustrando cada letra, seguida por uma tabela de sílabas correspondentes à letra.

\footnotetext{
${ }^{16}$ A professora Milena modificou essa organização, em uma das aulas, para a leitura conjunta de um texto em pequenos grupos. Assim, foram formados grupos de cerca de 5 (cinco) alunos, o que exigiu que as carteiras fossem agrupadas para facilitar a discussão entre os alunos.

${ }^{17}$ Nomes substituídos.
} 


\section{Perfil dos alunos participantes}

A seguir, explicitamos dados relevantes a respeito dos estudantes que colaboraram para esta pesquisa. Os dados representados nas tabelas que se seguem foram obtidos a partir de questionários respondidos pelos estudantes.

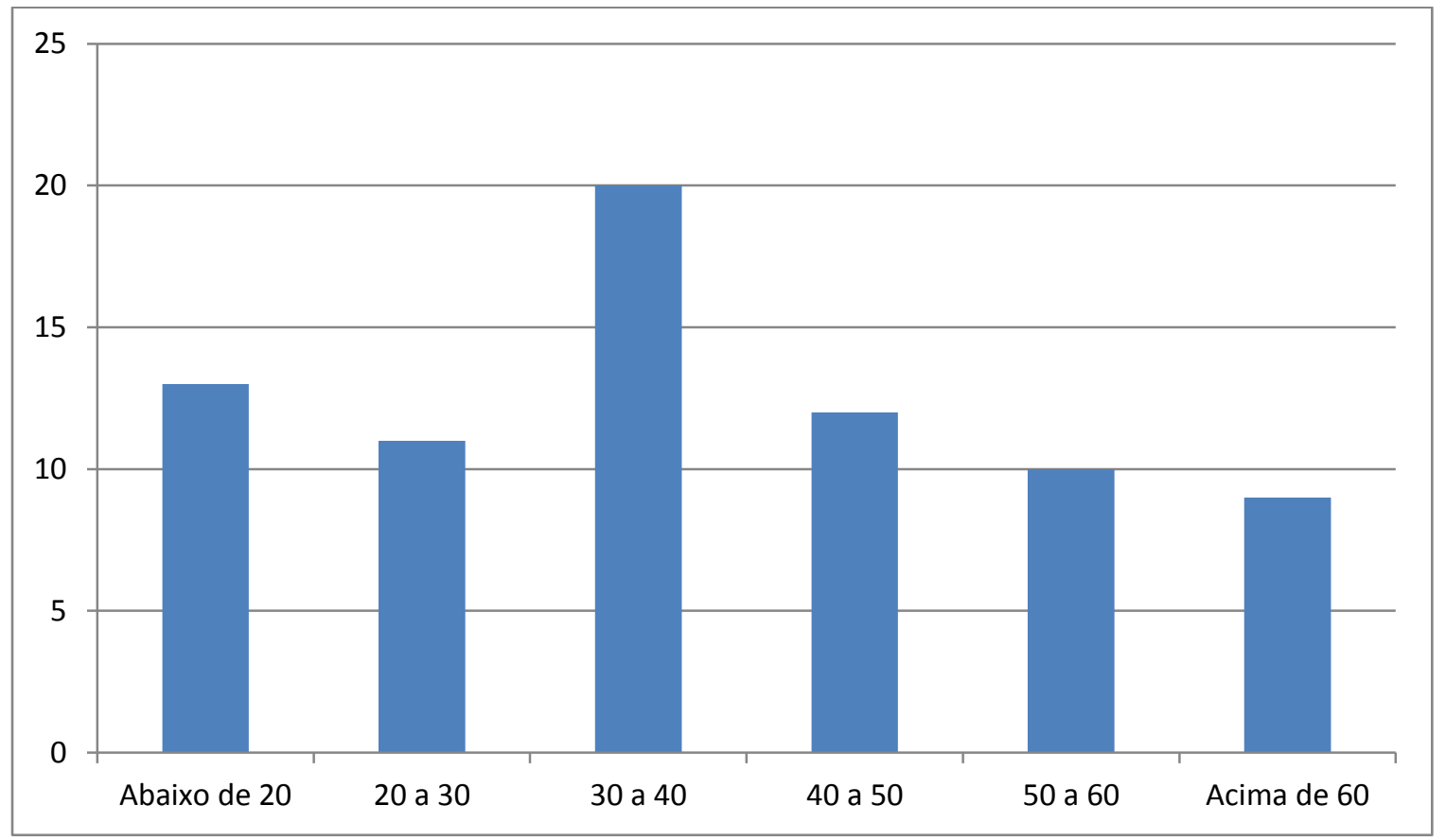

Tabela 2: Faixa etária dos alunos participantes: CENTRO EDUCACIONAL TRANDISCIPLINAR e ESCOLA MUNICIPAL PAULO FREIRE

\begin{tabular}{|c|c|c|}
\hline Sexo & Frequência & Porcentagem \\
\hline Feminino & 11 & $57,89 \%$ \\
\hline Masculino & 8 & $41,1 \%$ \\
\hline Total & 19 & $100 \%$ \\
\hline
\end{tabular}

Tabela 3: Alunos participantes por Sexo: CENTRO EDUCACIONAL TRANDISCIPLINAR

\begin{tabular}{|c|c|c|}
\hline Sexo & Frequência & Porcentagem \\
\hline Feminino & 31 & $53,45 \%$ \\
\hline Masculino & 27 & $46,55 \%$ \\
\hline Total & 58 & $100 \%$ \\
\hline
\end{tabular}

Tabela 4: Alunos participantes por Sexo: ESCOLA MUNICIPAL PAULO FREIRE 


\begin{tabular}{|c|c|c|}
\hline Área de Atuação Profissional & Frequência & Porcentagem \\
\hline Ajudante de Cozinha & 1 & $1,3 \%$ \\
\hline Ajudante Geral & 1 & $1,3 \%$ \\
\hline Aposentado & 2 & $2,6 \%$ \\
\hline Atendente & 4 & $5,19 \%$ \\
\hline Autônomo & 1 & $1,3 \%$ \\
\hline Auxiliar de Sala & 1 & $1,3 \%$ \\
\hline Auxiliar de Serviço Geral & 1 & $1,3 \%$ \\
\hline Cabeleireiro & 2 & $2,6 \%$ \\
\hline $\begin{array}{l}\text { Consultor de Vendas de Produtos } \\
\text { Cosméticos }\end{array}$ & 1 & $1,3 \%$ \\
\hline Costureiro & 2 & $2,6 \%$ \\
\hline Cozinheiro & 1 & $1,3 \%$ \\
\hline Dona de casa & 8 & $10,4 \%$ \\
\hline Eletricista & 1 & $1,3 \%$ \\
\hline Entregador & 1 & $1,3 \%$ \\
\hline Estudante & 6 & $7,8 \%$ \\
\hline Faxineiro & 1 & $1,3 \%$ \\
\hline Garçom & 3 & $3,9 \%$ \\
\hline Gerente de Vendas & 1 & $1,3 \%$ \\
\hline Maître & 1 & $1,3 \%$ \\
\hline $\begin{array}{c}\text { Manutenção e Instalação de Acessórios } \\
\text { Automotivos }\end{array}$ & 1 & $1,3 \%$ \\
\hline Mecânico & 1 & $1,3 \%$ \\
\hline Metalúrgico & 1 & $1,3 \%$ \\
\hline Monitor de Turismo & 1 & $1,3 \%$ \\
\hline Pedreiro & 1 & $1,3 \%$ \\
\hline Pintor & 2 & $2,6 \%$ \\
\hline Promotor & 1 & $1,3 \%$ \\
\hline Recepcionista & 1 & $1,3 \%$ \\
\hline Repositor & 1 & $1,3 \%$ \\
\hline Taxista & 1 & $1,3 \%$ \\
\hline
\end{tabular}




\begin{tabular}{|c|c|c|}
\hline Técnico Operacional & 1 & $1,3 \%$ \\
\hline Trabalhador doméstico, babá, diarista & 9 & $11,69 \%$ \\
\hline Vendedor & 1 & $1,3 \%$ \\
\hline Vigilante & 1 & $1,3 \%$ \\
\hline Não respondeu & 14 & $18,18 \%$ \\
\hline Total & 77 & $100 \%$ \\
\hline
\end{tabular}

Tabela 5: Área de atuação profissional dos alunos participantes

\begin{tabular}{|c|c|}
\hline \multicolumn{2}{|c|}{ Por que você estuda na EJA? } \\
\hline Motivo & 6 \\
\hline Exigência do mercado de trabalho & 5 \\
\hline Falta de tempo & 3 \\
\hline Dificuldades financeiras & 1 \\
\hline Dificuldades familiares & 1 \\
\hline Não precisou estudar antes & Outros: \\
\hline \multicolumn{2}{|c|}{ Porque trabalho à tarde. } \\
Não havia escola. \\
Reciclagem. \\
Falta de interesse. \\
\hline
\end{tabular}

Tabela 6: Razões para o estudo na EJA entre os alunos do CENTRO EDUCACIONAL

TRANDISCIPLINAR, alunos participantes

\begin{tabular}{|c|c|}
\hline \multicolumn{2}{|c|}{ Por que você estuda na EJA? } \\
\hline Motivo & Frequência \\
\hline Exigência do mercado de trabalho & 33 \\
\hline Falta de tempo & 3 \\
\hline Dificuldades financeiras & 9 \\
\hline Dificuldades familiares & 1 \\
\hline Não precisou estudar antes & \\
\hline
\end{tabular}




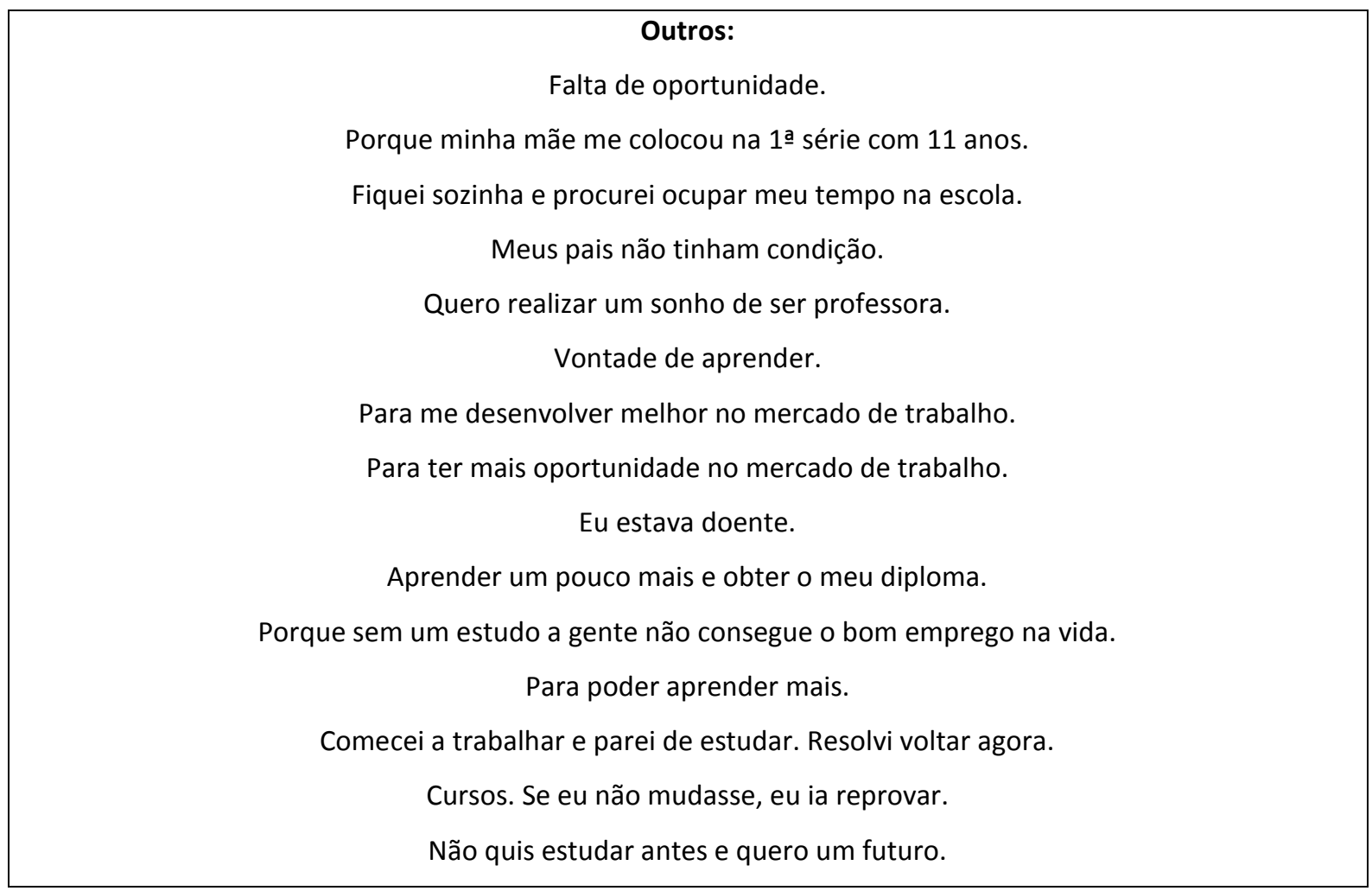

Tabela 7: Razões para o estudo na EJA entre os alunos da ESCOLA MUNICIPAL PAULO FREIRE, alunos participantes

\section{Tratamento dos dados}

As professoras colaboradoras e as escolas investigadas tiveram suas identidades preservadas por meio do uso de nomes fictícios. Também para que se mantivesse o sigilo quanto a suas identidades, os alunos entrevistados tiveram seus nomes substituídos por letras aleatórias, como A., J., B., C., etc.

Nas transcrições de trechos de aulas e de respostas aos questionários, os nomes dos alunos participantes foram substituídos pela letra correspondente à turma a que pertencem. Conforme a Tabela 1 acima, cada turma observada foi codificada com uma letra diferente. Assim, a turma da $3^{\text {a }}$ Etapa A, da professora Vívian foi nomeada "A". Comentários dos estudantes foram identificados pela letra correspondente à turma seguida de números para marcar a ordem de aparição das falas ou de acordo com a organização dos questionários por turma, como A1, A2, A3, B1, B2, etc. Isso significa que não há correspondência entre as identificações dos questionários e dos trechos de aulas reproduzidos neste trabalho. 
Em trechos onde há referências a pessoas ou locais que não fizeram parte direta da pesquisa, utilizamos XXX para manter o sigilo.

Em suma, nas transcrições de entrevistas e de questionários, constantes deste trabalho, encontramos:

Centro Educacional Transdisciplinar = nome fictício para escola participante

Escola Municipal Paulo Freire = nome fictício para escola participante

$\mathbf{P}=$ Pesquisadora

$\mathbf{V}=$ Vívian, nome fictício para a professora colaboradora do Centro Educacional Transdisciplinar

$\mathbf{M}=$ Milena, nome fictício para a professora colaboradora da Escola Municipal Paulo Freire

A., J., B., C., etc = aluno entrevistado, identificado de acordo com uma letra aleatória.

A1, A2, B1, B2 = aluno participante em sala de aula ou em resposta aos questionários, de acordo com a turma a que pertence

$(?)=$ Pequeno trecho em que não se compreende o que foi dito, por causa do ruído ou da fala de outros participantes.

( ) = Comentário da pesquisadora a fim de esclarecer e facilitar a compreensão do trecho.

\section{Organização da dissertação}

A pesquisa se apresenta ao longo de três capítulos, além deste capítulo introdutório.

No Capítulo 1, traçamos perspectivas teóricas que fundamentam esta pesquisa, focalizando nos estudos de letramentos, novos letramentos e multiletramentos. Abordamos, ainda, neste capítulo, temas relacionados aos nossos estudos, como a globalização e as perspectivas históricas, políticas e pedagógicas em EJA. 
No Capítulo 2, apresentamos e analisamos dados que apontaram a distância entre o letramento escolar e o letramento social dos alunos.

No Capítulo 3, trazemos para discussão dados que revelaram uma relação frutífera, mas conflituosa, entre os letramentos escolares e os letramentos sociais do alunado.

Finalizamos o trabalho com as considerações finais a esta pesquisa. 


\title{
CAPÍTULO 1 \\ BASES TEÓRICAS PARA O ENSINO DE INGLÊS NA EJA POR MEIO DOS NOVOS LETRAMENTOS
}

\author{
Todo ponto de vista é a vista de um ponto. \\ Ler significa reler e compreender, interpretar. \\ Cada um lê com os olhos que tem. \\ E interpreta a partir de onde os pés pisam. \\ Todo ponto de vista é a vista de um ponto. \\ Para entender como alguém lê, \\ é necessário saber como são seus olhos \\ e qual é a sua visão de mundo. \\ Isso faz da leitura sempre uma releitura. \\ A cabeça pensa a partir de onde os pés pisam. \\ Para compreender, é essencial conhecer o lugar social de quem olha. \\ Vale dizer: como alguém vive, com quem convive, \\ em que trabalha, que desejos alimenta, \\ como assume os dramas da vida e da morte \\ e que esperanças o animam. \\ Isso faz da compreensão sempre uma interpretação. \\ Sendo assim, fica evidente que cada leitor é co-autor. \\ Porque cada um lê com os olhos que tem. \\ Porque compreende e interpreta a partir do mundo que habita.
}

(BOFF 1997, p. 9-10)

\subsection{Introdução}

Neste capítulo, abordaremos um breve histórico das teorias que deram origem aos estudos de letramentos, fazendo um levantamento do que se produziu a esse respeito no Brasil e no mundo. Em seguida, trataremos das implicações da globalização para o ensino de língua inglesa na contemporaneidade. Finalizamos este capítulo traçando um recorte sobre as visões históricas, políticas e pedagógicas articuladas nos estudos em EJA.

As palavras de Leonardo Boff, teólogo expoente da Teoria da Libertação, trazem à baila diversas questões norteadoras a este trabalho, que se propõe a investigar os desafios de se aprender e ensinar Inglês como língua estrangeira na EJA, com o olhar dos estudos de novos letramentos e multiletramentos (COPE e KALANTZIS 2000; KALANTZIS e COPE, 2008, 2012, 2013; GEE, 2004, 2013, LEMKE, 2010, entre outros).

De minha perspectiva, Boff nos dá pistas sobre o processo interpretativo, que ocorre continuamente em nossas práticas sociais. A todo momento em que nos deparamos com qualquer conteúdo simbólico, podemos nos engajar em um processo interpretativo. É importante ressaltar que a interpretação descrita por Boff dialoga com a hermenêutica, como nos estudos de Ricoeur (1977), ramo da filosofia que teoriza a interpretação e que se baseia no 
pressuposto de que quem interpreta, interpreta a partir dos recursos simbólicos que possui, construídos em compartilhamento com uma ou mais comunidades linguísticas onde atua em práticas sociais. Assim, um texto tem sentido em relação a outros textos, cuja intepretação é uma construção de sentidos, um efeito da cultura. Essa perspectiva da hermenêutica aqui descrita se diferencia da hermenêutica tradicional, em que se interpretavam textos da Bíblia buscando compreender-lhes o sentido, pressupondo que o sentido estivesse escondido dentro do texto e precisava ser desvelado, em um processo conhecido como exegese (RICOEUR, 1977). Para os hermeneutas tradicionais, o sentido continha-se no próprio texto, não fora dele, em relação a outros textos e práticas.

O termo lugar, enunciado por Boff, nos proporciona múltiplos sentidos, todos de extrema importância. Tradicionalmente, tem-se a visão de que o local é um espaço físico, territorial. Com base neste conceito, desenvolveu-se o sentido de nação que fez muito pelo avanço capitalista-industrial a partir do século XIX, definindo fronteiras e justificativas para o progresso de comunicações, transportes e, em consequência disso, o desenvolvimento de tecnologia. A base filosófica predominante nesse período é o iluminismo, que prescreve um ser humano científico, racional e lógico, que trabalha sob a visão de membro individual de um corpo coletivo, a nação e as instituições que a constituem. A busca por um pensamento racional e científico, cujo expoente é o desenvolvimento científico a partir do século XIX, em que surgem nomes como Charles Darwin, acolhe também o conceito de escola como conhecemos hoje: instância por excelência da produção e da transmissão de conhecimento.

\subsection{O ensino de inglês e os estudos de novos letramentos e multiletramentos}

Surgidos ao final do século $\mathrm{XX}$, os novos estudos de letramentos (New Literacies Studies) e multiletramentos (Multiliteracies) derivam de uma busca de respostas às crescentes demandas da sociedade contemporânea, especialmente centralizadas nas transformações socioculturais provocadas pelo advento das novas tecnologias de comunicação e informação, sobretudo a Internet, e pelos efeitos da globalização.

Tanto os novos estudos de letramentos quanto os de multiletramentos têm por base os estudos de letramento (Literacy Studies) desenvolvidos a partir da década de 1970 por especialistas em variadas áreas de conhecimento. 
Acerca desses estudos, Lankshear e Knobel (2006) expõem que até a década de 1970 os estudos sobre leitura e alfabetização se concentravam basicamente na decodificação mecânica de textos, tendo como ponto de partida teorias advindas da psicolinguística. Luke e Freebody (1997) também reforçam que, em tais abordagens para a aprendizagem de leitura e escrita, o ato de ler é um processo natural de construção de significado realizado individualmente pelo leitor, que opera processos psicológicos apreendidos desde a infância e os aplica para compreender o texto. Pesquisadores do início do século XX apoiaram a afirmação do psicólogo behaviorista Thorndike (1917, apud LUKE, CASTELL e MACLENNAN, 1989) de que a leitura é um processo de estímulo textual e resposta do leitor. Assim, os conceitos de linguagem como estímulo e resposta foram importados da psicologia para a educação, conforme apontam Luke, Castell e MacLennan (1989).

Ainda de acordo com Luke, Castell e MacLennan (idem), tais conceitos embasaram abordagens tecnocráticas no decorrer do século XX, especialmente em países como os Estados Unidos e o Canadá, em que era notável a defesa da focalização de objetivos estritamente instrumentistas que se propõem a alcançar um aumento da eficiência institucional com a qual esses objetivos podem ser alcançados. Uma das consequências disso foi o aumento da pesquisa e do desenvolvimento restritos a sistemas de instrução padronizados e instrumentos de avaliação. Tais práticas educacionais, especialmente influenciadas pela crença em padrões de avaliação, e estipulação científica de objetivos educacionais ao modo de Tyler (1949 apud LUKE, CASTELL e MACLENNAN, ibid.), resultaram em definições pouco acauteladas de letramento. Com ênfase em objetivos imediatos e mensuráveis, houve uma tendência a se considerarem resultados predeterminados a curto prazo, tais como comportamentos, notas e habilidades, como sendo conceitos adequados a orientar as pesquisas em educação. Nesse contexto, construiu-se uma visão de letramento como sendo um conjunto de sub-habilidades precisamente especificáveis e mensuráveis. Daí que, segundo os autores, tais exigências de controle educacional por meio de testes acabaram por aferir uma "crise de leitura" sem que se considerassem a aquisição e o uso de leitura que uma visão contextualizada poderia promover, isto é, levando-se em conta o letramento e seus aspectos históricos, sociais, linguísticos. Assim, os autores questionam a deficiência de informações sobre como se definir letramento, apontando falhas em diversas pesquisas desenvolvidas em se demarcar o problema em si. Portanto, os autores advogam, em fins dos anos 1980, uma agenda de pesquisas sobre letramento no contexto em que este se situa. 
Até então, o termo literacy, relativamente recente, conforme Barton (1994), restringiase ao contexto de ensino não-formal de leitura e escrita para adultos não alfabetizados. Para Lankshear e Knobel (2006), o emprego do termo literacy somente no contexto de alfabetização de adultos sinaliza que até aquele momento a concepção de letramento se restringia a uma exceção à regra de um universo letrado, isto é, letramento descrevia uma situação de "segunda chance" num universo em que a educação formal cumpria o papel da alfabetização na quase totalidade de casos.

Barton (idem) descreve que o conceito de letramento passou a ganhar especial atenção por parte do conhecimento acadêmico quando esse se voltou para questões que articulam novas perspectivas sobre leitura e escrita.

Mais do que isso, a partir da década de 1980, como consequência desse crescente interesse acadêmico pelo conceito de letramento, estabelece-se uma nova área de conhecimento, Literacy Studies (BARTON, ibid.). Diversas são as abordagens para tais estudos, com colaborações de estudiosos de diversas disciplinas, teorias e métodos, mas o denominador comum identificado por Barton (ibid.) é a perspectiva de letramento situado em seu contexto social, o que também se identifica em Luke e Freebody (1997) e Gee (2004, 2013), segundo os quais a abordagem dos estudos do letramento, mais do que as capacidades individuais abordadas em estudos tradicionais de psicologia, leva em conta que o letramento é um fenômeno social, de pessoas que não atuam sozinhas, mas na sociedade.

Três estudos destacados por Barton (ibid.) são os desenvolvidos por Sylvia Scribner e Michael Cole (1981); Brian Street (1984) e Shirley Brice Heath (1983).

O trabalho de Sylvia Scribner e Michael Cole tem o mérito de distanciar-se de visões tradicionais de leitura e escrita como sinônimas a tecnologias mecânicas, para aproximar-se de uma abordagem de letramento como um conjunto de práticas socialmente organizadas que recorrem ao conhecimento de um sistema simbólico aplicando-o a propósitos específicos em contextos específicos de uso.

Brian Street parte de metodologias de descrição etnográfica em uma atividade antropológica para advogar uma abordagem de letramento ideológica, isto é, pressupondo que o conceito de letramento varia de acordo com a situação e depende da ideologia. Tal abordagem contrasta com o que o autor chama de abordagem autônoma, isto é, que afirma que a definição de letramento independe do contexto social. Na visão de Kleiman (1998), embora o letramento autônomo equivalha ao letramento acadêmico e tenha na escola seu 
principal agente, o fenômeno do letramento socialmente contextualizado pode ser examinado na escola, levando-se em conta "aspectos ideológicos, socialmente determinados, do fenômeno, especialmente, quando contrastamos aspectos da cultura letrada com aspectos da cultura escolar." (KLEIMAN, 1998, p. 100).

Shirley Heath, em seu trabalho seminal Ways with Words, também derivado de métodos etnográficos tal qual o de Brian Street, contribui para os estudos de letramento com seu contraste entre as funções (o que o letramento pode fazer com as pessoas) e os usos de letramento (o que as pessoas fazem com o letramento). Outra colaboração de Heath é o foco nos eventos de letramento, isto é, em situações reais de leitura e escrita na rotina das pessoas. Além disso, sua contribuição é notada no alerta para o estabelecimento de relações entre os eventos de letramento na escola e os ocorridos em casa e na comunidade.

Com esses e outros trabalhos, nota-se o conceito de letramento situado no contexto sociocultural em que ele ocorre. É por meio desses trabalhos que os estudos de letramento passam a ser desenvolvidos também no Brasil, conforme esclarecido por Soares (2005) e Rojo (2011). Soares (2005) afirma que o termo letramento é empregado pela primeira vez em 1986 traduzido do termo do inglês, literacy. Convencionou-se, então, o termo letramento para difundir essas novas concepções acerca dos processos de aprendizagem que consideram aspectos sociais.

O termo letramento passa a ser utilizado no meio acadêmico brasileiro em oposição aos conceitos de alfabetização e de alfabetismo, ou seja, como uma forma de diferenciar os estudos sobre o impacto social da escrita dos estudos que enfatizam apenas as capacidades individuais dos estudantes em decodificar textos. Rojo (2011) enfatiza ainda a distinção entre alfabetização e alfabetismo, esclarecendo que, enquanto alfabetizar é a ação de ensinar a ler e a escrever levando o aprendiz a conhecer a mecânica da escrita e da leitura, a se tornar alfabetizado, o alfabetismo é conceito complexo que envolve a leitura de forma a compreendê-lo, acionando seus conhecimentos de mundo para relacioná-lo com os temas do texto, intertextualizando, prevendo, hipotetizando, inferindo, comparando informações, generalizando, etc. Ambos os conceitos têm na instituição escolar e, consequentemente nas práticas de leitura valorizadas pela escola, o seu principal agente. Já o letramento procura considerar os usos e práticas sociais que envolvem a escrita, escolares ou não, valorizadas ou não, locais ou globais, abordando contextos sociais variados em uma perspectiva sociológica, antropológica e sociocultural (ROJO, idem, p. 98). 
Lankshear e Knobel (2011) elucidam que as razões para essa abordagem voltada para o social residem, dentre outros fatores: 1) no trabalho de Paulo Freire e no movimento de educação radical; 2) na descoberta de uma crise de analfabetismo no começo da década de 1970 nos Estados Unidos; 3) nas relações entre letramento, crescimento econômico e bemestar social; 4) nas relações entre letramento, accountability, eficiência e qualidade; 5) no desenvolvimento e popularização da teoria sócio-cultural.

Para Lankshear e Knobel (2006), a compreensão de letramento a partir de uma perspectiva sociocultural significa que escrita e leitura só podem ser entendidos nos contextos de práticas sociais, culturais, políticas, econômicas e históricas nos quais eles se inserem. Segundo os autores:

Todos os textos que lemos e escrevemos são elementos integradores de práticas vividas, discutidas, baseadas em valores e crenças, nas quais as pessoas se engajam sob condições específicas, em tempos específicos, e em lugares específicos (LANKSHEAR; KNOBEL, 2006, p. 2, tradução nossa)

Além disso, os autores sublinham a relação dialética entre o contexto do qual emerge a língua e a língua, inscritos em um processo constante de construção e reconstrução mútuas de significados, conforme se observa no trecho abaixo:

Não há prática sem significado, assim como não há significado sem prática. Dentro dos contextos de prática humana, a língua (palavras, letramento, textos) dá significado aos contextos e, dialeticamente, os contextos dão significado à língua. Assim, não há leitura ou escrita em algum sentido de cada termo que exista fora de práticas sociais. (LANKSHEAR; KNOBEL, 2006, p. 2, tradução nossa)

A noção de que o letramento se baseia em textos inscritos em práticas sociais e culturais leva à percepção de que se existe uma variedade de práticas sociais, também existe uma variedade de letramentos, no plural. Gee (2004) aponta que ao se considerar os letramentos no plural, depreende-se que não há uma forma generalizada de leitura e escrita, mas textos específicos produzidos e interpretados de modos específicos, determinados pelos valores e práticas dos diferentes grupos sociais e culturais.

Para realçar a produção de textos e significados articulada a um contexto social, histórico e econômico específico, Lankshear e Knobel (idem) reforçam as conotações sociais embutidas no termo illiteracy, ou, em português, 'analfabetismo'. Os autores apontam que, nesse sentido, Paulo Freire, educador pernambucano que ao alfabetizar trabalhadores rurais no Brasil na década de 1960, colaborou para mudanças nas concepções de leitura, escrita e alfabetização chamando a atenção de estudiosos de diversos países para o fato de que o analfabetismo, até dado momento praticamente inexistente em países anglo-saxões, é uma constante que resulta de injustiças sociais em países como os do então chamado "terceiro 
mundo", além de alertar para a necessidade de uma educação voltada para a libertação de situações opressoras por meio da palavra.

Barton (ibid.) também elucida que o trabalho de Freire está situado em um contexto diferente do dos demais estudiosos e isso colabora para uma abordagem diferente de letramento que rompe com perspectivas neutras a respeito da alfabetização. Segundo Barton (ibid.), Freire explicita o fato de que a alfabetização se situa em um contexto social, em que especificamente se examina não ser coincidência que adultos que não saibam ler e escrever sejam também os mais pobres, os menos empoderados, os mais oprimidos. O analfabetismo é resultado de situações de desigualdade e injustiça, o que se configura como o ponto de partida para o trabalho desenvolvido por Freire, com abordagem crítica. Como um potencial elemento de transformação do contexto em que se insere, o trabalho de Freire tem como passo inicial analisar e compreender a posição social que o sujeito aprendiz ocupa.

\subsection{Letramento crítico}

O trabalho de Freire nos anos 1970 tem efeito sobre os acadêmicos de diversos países, influenciando-os no desenvolvimento de estudos de letramento crítico, conforme elucidam Cervetti, Pardales e Damico (2001), ao examinarem e diferenciarem a leitura crítica do letramento crítico, duas abordagens geralmente confundidas. De acordo com os autores, nos conceitos de leitura crítica, a interpretação de um texto depende da descoberta da intenção de seu autor. A hipótese filosófica, portanto, é a visão liberal-humanista de que cada pessoa, com sua capacidade racional, codifica as próprias ideias e pensamentos em textos interpretados por seus leitores e que refletem uma realidade conhecida, distinta entre fatos e inferências e entre verdade e retórica. Dito de outro modo, o pensamento é traduzido em linguagem que se desdobra em dois princípios: existe a linguagem descritiva e objetiva da verdade e a linguagem descritiva do mundo que visa a persuadir e a provocar experiências estéticas. Pensar criticamente, nesse caso, é pensar racionalmente: deliberadamente, ordenadamente, intencionalmente, criticamente. Daí compreende-se a ideia de que há interpretações corretas e interpretações incorretas dos textos, que podem estar infiltrados pela intenção do autor que pode e deve servir como base para a compreensão (CERVETTI, PARDALES e DAMICO, 2001). Entre o fim da década de 1940 e o começo da década de 1970 foram publicadas muitas pesquisas educacionais sobre leitura crítica, o que teve o seu ápice nas décadas de 1950 e 1960. Os autores atribuem tal fato à chamada "ameaça comunista" do pós-guerra aliada ao 
avanço tecnológico e à difusão da comunicação de massas predominantes no período, resultando em novas perspectivas pedagógicas que se prestavam a preparar os estudantes para viver em um mundo mais complexo.

O letramento crítico, diferentemente da leitura crítica, conforme esclarecem Cervetti, Pardales e Damico (idem), se baseia no processo de construção do texto, não na sua interpretação. Atribui-se o significado ao texto, ao invés de extrair-lhe os sentidos, o que ocorre dentro de seu contexto social, histórico e de relações de poder. Em um nível avançado, ler, dentro dos pressupostos do letramento crítico, é um ato de conhecimento do mundo (e a palavra) assim como um meio de transformá-lo.

A história filosófica do letramento crítico é complexa, derivando em parte da teoria de crítica social, do trabalho de Paulo Freire e do pós-estruturalismo (CERVETTI, PARDALES e DAMICO, ibid.). O alinhamento à teoria de crítica social é percebido especialmente na tentativa de formação de um mundo mais justo que subjaz a crítica aos problemas sociais e políticos, como a opressão e a exploração, e, como consequência, uma postulação de alternativas. Acredita-se, nessa perspectiva, que a linguagem é tanto o instrumento de crítica quanto o de transformação da desigualdade. Citando Morgan (1997, apud CERVETTI, PARDALES e DAMICO, ibid.), em sala de aula, questiona-se quem constrói os textos cujas representações são dominantes em uma determinada cultura em um determinado momento; como os leitores se tornam aliados das ideologias persuasivas contidas nos textos; de quem são os interesses servidos por tais representações e leituras e quando as leituras têm efeitos injustos; e, por fim, como tais efeitos podem ser construídos de outra maneira.

Ainda de acordo com esses autores, em Paulo Freire, que compartilha as visões das teorias da crítica social, há uma transposição das preocupações filosóficas de tal corrente teórica para a área da educação. Freire entende a linguagem e o letramento como mecanismos fundamentais para a justiça social, a transformação econômica e a luta por emancipação, dentro do contexto de questionamentos críticos do mundo. Assim, o objetivo pedagógico defendido por Freire é o desenvolvimento da consciência crítica, capacidade de ler textos e o mundo e, a partir da crítica dos textos, tornar-se um ser atuante contra situações opressivas, reconhecendo-se e dispondo-se a refazer as próprias identidades e realidades sociopolíticas.

Os autores afirmam que é do pós-estruturalismo que, mais recentemente, o letramento crítico herda a concepção de que textos só possuem significados quando relacionados a outros significados e práticas em contextos sociopolíticos específicos. Dessa forma, produzem-se textos a serem interpretados por indivíduos sob sistemas discursivos que regem o 
conhecimento em uma ambientação particular. O julgamento quanto à veracidade dos enunciados ocorre em relação a esses sistemas, construídos por instituições e comunidades. A perspectiva pós-estruturalista mina qualquer pressuposto de neutralidade ou verdade na aferição do valor das interpretações, uma vez que se percebe a língua como relações desiguais de poder, que se materializa em textos sempre ideológicos, nunca factuais (CERVETTI, PARDALES e DAMICO, ibid.).

De acordo com Luke e Freebody (1997) o letramento crítico não pressupõe uma abordagem única de trabalho, por ser marcado por uma coalizão de interesses educacionais comprometidos a engajar as possibilidades da linguagem para a mudança social, a diversidade cultural, a igualdade econômica e a emancipação política.

Embora se reconheça o aspecto da individualidade nas práticas de letramento, tais como a construção de agência, a cognição e as características comportamentais, tais práticas não podem ser compreendidas sem os significados da atividade social, que opera centralmente das instituições, o governo, a mídia, entre outros. Portanto, se o letramento é construído socialmente, ele é situado institucionalmente. O contexto institucional é informado por contratos sociais e projetos históricos para modelar, construir e disciplinar sujeitos e populações.

A questão da criticidade se acentua à medida que se percebe uma desconexão entre os currículos tradicional e progressivo e os problemas e necessidades educacionais de grupos significativos de estudantes, particularmente aqueles em grupos historicamente vulneráveis inseridos em comunidades de baixo poder socioeconômico, minorias culturais, entre outros.

Luke e Freebody (idem) revelam ainda que as questões de letramento envolvem poder político e cultural, acesso a riqueza, configurações de gênero, etnia, classe e cidadania, representados nos textos. Essa visão sociocultural de letramento permite que o consideremos um encorajamento ao desenvolvimento de posições alternativas de leituras e práticas de questionamento e crítica dos textos e formações sociais e conjeturas culturais.

Considerando os efeitos do mundo globalizado dos dias atuais, como os conflitos que podem ocorrer com a aproximação de populações e culturas diferentes entre si, Menezes de Souza (2011) atribui uma nova função para o letramento crítico, qual seja, o preparo dos aprendizes para lidar com os mais variados tipos de diferença. De acordo com o pesquisador, para cumprir com essa nova função, o letramento crítico precisa ser redefinido, acrescentando-se às suas práticas a genealogia, isto é, a compreensão da própria leitura inserida em seu contexto de produção. Nesse sentido, o referido pesquisador realça o processo 
de recepção dos textos como uma ação de construção sócio-histórica e coletiva de sentidos, processo que ocorre em conformidade com a comunidade na qual o leitor se insere. De acordo com este autor, o letramento crítico envolve o processo, já sugerido por Freire (2011) de “ouvir-se escutando o outro" (MENEZES DE SOUZA, idem). Contrariando a expectativa de convergência harmoniosa entre o eu e o outro no processo de interação e construção de significados, Menezes de Souza (ibid.) propõe que o letramento crítico, redefinido, promova o ensino e a aprendizagem acerca da compreensão de si próprio em coletividade, escutando a si próprio em relação ao outro, porém sem a tentativa de apagar ou silenciar as diferenças, como se depreende do trecho abaixo:

\begin{abstract}
O que resulta desse processo de escutar é a percepção da inutilidade de querer se impor sobre o outro, dominá-lo, silenciá-lo ou reduzir sua diferença à semelhança de nosso 'eu'; a escuta cuidadosa e crítica nos levará a perceber que nada disso eliminará a diferença entre nós mesmos e o outro, e nos levará a procurar outras formas de interação e convivência pacífica com as diferenças que não resultem nem no confronto direto e nem na busca de uma harmoniosa eliminação das diferenças. (MENEZES DE SOUZA, ibid., p. 6)
\end{abstract}

\title{
1.4 De letramento (Literacy Studies) a Novos Letramentos (New Literacy/Literacies Studies)
}

Com o advento da popularização das novas tecnologias digitais nos anos 1990, urge a compreensão do fenômeno dos letramentos ocorridos sob uma perspectiva que vá além do suporte impresso, dando origem aos Novos Letramentos (New Literacies). A inclusão de "novos" diante do termo letramentos é esclarecida por Lankshear e Knobel (2011) como uma forma de revisitar os estudos de letramento da década de 1970, bem como um modo de ressaltar mudanças na sociedade atual. Há duas mudanças importantes nesse sentido e que se distinguem de duas formas.

Embora muitos conceitos sejam emprestados dos Literacy Studies, como o da linguagem escrita como uma tecnologia para a produção de significados situados nas práticas sociais, culturais, históricas e institucionais em que ocorrem, atribuindo às tecnologias digitais o mesmo papel da linguagem e da tecnologia da escrita, Gee (idem) realça os Novos Estudos de Letramento (New Literacy Studies) como uma forma diferente de compreender o fenômeno do letramento, enquanto os Novos Estudos de Letramentos (New Literacies Studies) propõem o estudo acerca de novos tipos de letramento, em especial os letramentos digitais e as práticas de letramento inseridas na cultura popular. 
Lankshear e Knobel (idem), entretanto, parecem não distinguir as duas abordagens como áreas de estudos distintas, mas as entendem como sendo complementares e atuantes em aspectos diferentes da mesma questão. Os autores esclarecem que, por um lado os novos letramentos compreendem práticas sociais já existentes e, por outro lado, novos letramentos correspondem de fato a letramentos e práticas sociais nunca antes vividos e estudados oficialmente, como resultado de novos suportes materiais (KRESS, 2003), isto é, novas tecnologias de informação e comunicação. Assim, Lankshear e Knobel (2006) colaboram para os estudos de novos letramentos coletando, de um lado, exemplos práticos de novos letramentos, isto é, práticas e eventos de letramento inéditos, possibilitados por novas tecnologias digitais, como elaboração de fan fiction, utilização de sites para a participação em comunidades organizadas por afinidades e práticas sociais que envolvem smartphones. Por outro lado, os autores também coletam abordagens para pesquisa e estudos socioculturais de novos letramentos.

A importância desses estudos é realçada por Gee (ibid.) ao sublinhar que as ferramentas digitais têm promovido equilíbrio entre a produção e o consumo de mídias. Isto é, conforme as ferramentas se sofisticam, os conteúdos digitais são produzidos, cada vez mais, por pessoas comuns, não especialistas ou empresas, o que tem um impacto significativo na transformação das relações com o conhecimento e na participação das pessoas em sua produção, com maior nível de engajamento. Além disso, as ferramentas digitais têm modificado a natureza dos grupos, das formações sociais e de poder, o que resulta em maior facilidade de mobilidade e ações rápidas.

Lemke (2010) aponta para a possibilidade, ofertada pelas tecnologias digitais, de espaço para hibridismos de culturas não hegemônicas além da mudança de paradigmas de aprendizagem curriculares tradicionais para paradigmas mais interativos e colaborativos. Para o autor,

\footnotetext{
“a nova ordem cultural mundial não será menos diversa do que a atual, mas sua base expandirá através da geografia e da herança familiar para incorporar interesses compartilhados e a participação em comunidades centradas em atividades" (LEMKE, 2010, p. 468)
} 


\subsection{Multiletramentos}

Em 1994 inicia-se o New London Group, grupo formado por dez pesquisadores reunidos com a finalidade de debater o propósito da educação no contexto da multiplicidade de canais de comunicação e a crescente diversidade cultural e linguística no mundo globalizado. Embora advindos de contextos e formações profissionais e acadêmicas diferentes, os pesquisadores do New London Group compartilham a defesa da necessidade de se compreender os resultados sociais do letramento. Defendem também que se repensem as premissas que subjazem as práticas pedagógicas que darão condições aos alunos a alcançarem suas aspirações em um mundo de constantes mudanças.

Convém ainda esclarecer que, mais recentemente, pesquisadores, especialmente representados por Cope e Kalantzis (2003), empregam o termo multiliteracies, ou multiletramentos, para designar os estudos de letramentos que se expandem na negociação de múltiplos discursos, intermediados pelos aspectos da diversidade cultural e linguística em sociedades globalizadas, bem como pela multiplicidade de variedades formais de textos disponibilizadas pelas novas tecnologias de informática e comunicação.

Conforme Kalantzis e Cope (2012), o termo multiletramentos, do original em inglês multiliteracies, refere-se a dois aspectos principais da produção de significados: diversidade social e multimodalidade.

De acordo com Cope e Kalantzis (2003), uma pedagogia de multiletramentos focalizase na noção de modos de representação e comunicação. Kalantzis e Cope (2013) nos informam que dois aspectos principais de representação e comunicação que originam a ideia de multiplicidade inscrita no termo multiletramentos são (1) a variabilidade de convenções de significados em diferentes situações culturais, sociais ou em domínios específicos e (2) a multimodalidade. No que diz respeito à variabilidade de convenções de significado, os autores relembram o valor social da linguagem já enfatizado por Gee (1996 apud COPE; KALANTZIS, 2003). Nesse posicionamento social, há abertura para a dinamicidade de processos de representação e comunicação de modo a possibilitar transformações sociais, ao invés de limitar-se a transmitir/reproduzir. Nessa perspectiva, cada ato de construção de significados opera na reorganização de artefatos representacionais disponíveis, conforme pontuam Kalantzis e Cope (2013). Como consequência do caráter transformador/transgressor presente à construção de significados, os autores enfatizam que a pedagogia de letramentos tem sido historicamente marcada por tentativas de torná-lo um instrumento de design social que garante a estabilidade e a uniformidade (KRESS, idem). 
Tal visão sobre o caráter reprodutivo da escolarização como forma de contenção das transformações sociais também é compartilhada e denunciada por Bourdieu (2011). De acordo com Bourdieu (2011), o sistema educacional converte hierarquias sociais em hierarquias escolares, logo, cumpre uma função de legitimação necessária à manutenção da "ordem social" por substituir o uso da força para que tal ordem se constitua. Para facilitar a compreensão acerca da correlação entre o sistema social e o sistema econômico, reproduzidos pelo sistema escolar, Bourdieu (idem) nomeia-os de mercado, sendo o capital a sua moeda de troca. Para o autor, existem variados tipos de mercado, como o linguístico, o simbólico e o escolar, enquanto há, também, variados tipos de capital além do propriamente econômico, tais como o capital cultural e o capital social. Nesses termos, a escola é uma instância de transmissão de capital cultural, porém, sem a posse do capital econômico, os indivíduos não obtém chances significativas de sucesso no mercado. Pelo contrário, aqueles com as maiores chances de detenção do capital cultural são os que já possuem o capital econômico (BOURDIEU, 2011, p. 334).

Para que se rompa com a função reprodutora da escola e se alcance maiores oportunidades de transformação social, Cope e Kalantzis (2003) acreditam que a pedagogia dos letramentos seja mais abrangente e adequada do que um estudo de língua de forma isolada. Esses modos variam de acordo com a cultura e o contexto e têm efeitos cognitivos, culturais e sociais específicos. Conforme elucidam os autores, a pedagogia de multiletramentos leva em consideração as contínuas mudanças sociais resultantes da dinamicidade dos recursos representacionais, constantemente modificados de acordo com os interesses e necessidades de seus usuários. Nas sociedades em permanente transformação, o emprego dos multiletramentos pode capacitar os alunos ao acesso à linguagem, sempre em mudança, do trabalho, do poder e da comunidade, apoiando o engajamento crítico para que eles planejem seus futuros sociais. Sob o ponto de vista da pedagogia dos multiletramentos, o papel da escola como acesso e instrumento de futuros sociais se constrói tendo uma metalinguagem da pedagogia sob o conceito de design, termo com o qual Cope e Kalantzis (idem) designam o constante processo de estruturação e reestruturação de currículos e práticas escolares que refletem e resultam em diferentes formas de aprendizado, de acordo com as necessidades específicas dos aprendizes. Conforme os autores, os praticantes de multiletramentos, em suas inteligências criativas, estão aptos a redesenhar continuamente suas atividades no ato de praticá-las. Como consequência disso, a prática de multiletramentos permite uma constante investigação da variedade dos processos de construção de sentido, 
acolhendo diferentes culturas, subculturas e identidades daqueles que participam de tal processo. Esse processo requer engajamento e participação ativa dos usuários da língua como construtores de significados e conhecimentos, não apenas reprodutores/transmissores. É por isso que Cope e Kalantzis acreditam que a pedagogia dos multiletramentos favorece o desenvolvimento de agência entre seus aprendizes.

O processo de construção de identidades é ainda mais significativo quando se considera o inglês, ao mesmo tempo uma linguamundi, globalizada, como uma língua que se fragmenta em "várias línguas inglesas" conforme as peculiaridades e origens de seus usuários, cujo número de "não nativos" já ultrapassou o de nativos ao redor do mundo.

Monte Mór (2007) ressalta que os estudos e pesquisas sobre novos letramentos e multiletramentos, apesar de datarem das décadas finais do século XX, ainda estão em fase inicial no Brasil, o que demanda levantamentos e investigações para que se interpretem localmente as diversas questões que a eles se relacionam.

Atualmente, uma ampla rede de pesquisa voltada para os estudos de letramento entre professores e pesquisadores brasileiros, o Projeto Nacional de Formação de Professores, Educação Crítica, novos letramentos e multiletramentos, sediado na Universidade de São Paulo e coordenado pelos professores Walkyria Monte Mór e Lynn Mario Trindade Menezes de Souza, encontra-se em desenvolvimento em diversas universidades brasileiras e conta com o apoio de estudiosos internacionais, como Diana Brydon (University of Manitoba, Canadá) e Ilana Snyder (Monash University, Austrália). Mary Kalantzis e Bill Cope (University of Illinois, EUA), em recente visita a São Paulo conheceram os detalhes do referido projeto e expressaram apoio ao mesmo e interesse em parcerias e intercâmbio. Como resultado do projeto, seis seminários de abrangência nacional foram realizados (em agosto de 2009, setembro de 2010, setembro de 201, setembro de 2012, fevereiro de 2014 e fevereiro de 2015) para promover debates e compartilhar os trabalhos dos professores e pesquisadores em seus locais de atuação.

\subsection{Inglês e globalização}

Compreender o papel dos letramentos, considerando o ensino e a aprendizagem de língua inglesa de forma situada no contexto sociocultural, histórico e econômico em que eles ocorrem requer a ampliação de nossa perspectiva para o fenômeno da globalização. 
O fenômeno da globalização é entendido e definido de maneiras diferentes conforme mudam as perspectivas daqueles que se propõem a fazê-lo. De modo geral, recorrem as visões de que a globalização é um fenômeno com origens há pelo menos 60 mil anos, provável data das primeiras migrações de humanos que deixaram o continente africano, como ressaltam Suarez-Orosco (2007) e Kalantzis e Cope (2012).

Entretanto, convém esclarecer que tratamos aqui do movimento econômico e político iniciado e expandido nos últimos anos do século XX. Tal movimento, segundo explicita Castells (2011), é resultante da reestruturação das empresas e dos mercados financeiros em consequência da crise econômica da década de 1970 e teve sua expansão relacionada às tecnologias da informação e comunicação. A economia global não teria sido possível, em grande parte, sem a atuação de políticas de desregulamentação, privatização e liberalização de comércio e investimentos por parte de governos, que permitiram a interação entre mercados e instituições financeiras. Com base no aumento da produtividade e da lucratividade, as empresas procuraram novos mercados, o que gerou a internacionalização da produção, contando com não apenas consumidores, mas também mão de obra internacional (CASTELLS, idem).

Castells (ibid.) aponta que dessa nova forma de produção e consumo resultou uma transformação do emprego e do trabalho, com considerável aumento de exigência quanto aos níveis educacionais e às habilidades dos trabalhadores, o que, por um lado, acabou por supervalorizar algumas carreiras, enquanto, por outro, tornou outras menos valorizadas.

Ainda segundo os estudos de Castells (ibid.), a mudança mais aparente em decorrência da globalização é a transformação da comunicação por meio das tecnologias digitais, cujo maior expoente é a rede mundial de computadores, a internet. Embora a internet seja uma tecnologia mais antiga, utilizada pela primeira vez em 1969, sua popularização ocorreu na década de 1990 devido a uma série de razões, como as mudanças regulatórias, o que incluiu sua privatização; a maior largura de banda das telecomunicações; a difusão dos computadores pessoais; o acesso e a comunicação do conteúdo, via World Wide Web; as necessidades das empresas e o desejo do público de criar suas próprias redes de comunicação.

Nesse contexto, a língua inglesa ganha status de língua franca, sendo um facilitador em transações financeiras, nas comunicações entre internautas de diferentes localizações e na produção e propagação de conhecimentos científicos. A definição de globalização destacada por Brydon (2010) e que merece atenção por sua preocupação com o papel da educação é 
retirada de um relatório produzido para a UNESCO em 2009 sobre o ensino superior, acentua o papel do conhecimento de língua inglesa. De acordo com o relatório, a globalização é:

\begin{abstract}
"a realidade construída por uma economia mundial cada vez mais integrada, novas tecnologias de informação e comunicação (TIC), a emergência de uma rede de conhecimento internacional, o papel da língua inglesa, e outras forças além do controle das instituições acadêmicas" $" 18$ (ALTBACH, REISBER \& RUMBLEY, 2009, p. ii, apud BRYDON 2010, p. 17, tradução nossa).
\end{abstract}

São grandes as controvérsias no que diz respeito aos posicionamentos diante do fenômeno, como a polarização entre incluídos e excluídos da globalização, a acentuação das desigualdades entre países desenvolvidos e em desenvolvimento e o enfraquecimento da agência da mão de obra, conforme explicitadas por Bauman (1999).

Corroborando tais ponderações, Brydon (idem) sublinha que o contexto da globalização pode trazer desvantagens para os países do sul globalizado e do sul interno dos países em desenvolvimento, utilizando-se da metáfora geográfica para designar a condição de subalternidade e marginalidade do sistema mundial. A autora ressalta que o ensino de inglês no contexto descrito requer pelo menos duas considerações que merecem atenção especial: o reconhecimento de seu valor de uso nas condições atuais, por um lado; por outro lado, a criticidade dos pressupostos e valores acrescentados à língua e à aceitação de sua hegemonia global. (BRYDON, ibid., p. 18).

$\mathrm{Na}$ esfera educacional, a globalização impulsionada pelas tecnologias digitais tem como efeito uma maior disponibilização de comunicação com pessoas diferentes, com a possibilidade de contato e conhecimento de diferentes acepções de experiências, nacionalidades, língua, raça, religião e valores, conforme enfatizam Suarez-Orozco e Sattin (2007). Para os autores, o elemento central da globalização é trazer à baila o desafio da diferença e da complexidade para a vida das pessoas, o que atribui à educação um papel fundamental na formação de pessoas que consigam administrar as diferenças. Assim, a complexidade inerente à globalização urge um novo paradigma para o ensino e a aprendizagem, deixando a reprodução mecânica de conteúdos para privilegiar a flexibilidade e a agilidade. Portanto, a educação para a globalização deve fomentar habilidades cognitivas e interpessoais exigidas para a busca de resolução de problemas, a partir de múltiplos pontos de vista, exigindo que os indivíduos sejam flexíveis cognitivamente, culturalmente sofisticados e capazes de trabalhar colaborativamente em grupos heterogêneos. Diante do cenário descrito, o

18 "the reality shaped by an increasingly integrated world economy, new information and communications technology (ICT), the emergence of an international knowledge network, the role of the English language, and other forces beyond the control of academic institutions" (ALTBACH, REISBER \& RUMBLEY, 2009, p. ii). 
papel da educação é o de fomentar e estimular habilidades cognitivas, sensibilidades interpessoais, e sofisticação cultural entre crianças e jovens cujas vidas sejam engajadas em contextos locais ainda que repletas de realidades transnacionais, ajudando-as a serem bem sucedidas na complexidade e na diversidade que definem a era global (SUAREZ-OROZCO, QIN-HILLIARD 2004; SUAREZ-OROZCO, SATTIN, 2007, p. 12). 


\subsection{Perspectivas em Educação de Jovens e Adultos no Brasil}

Nesta seção, traçaremos um recorte do histórico da Educação de Jovens e Adultos, articulando-o às principais concepções pedagógicas e de linguagem que norteiam as pesquisas e as práticas nessa modalidade.

A literatura a respeito do tema nos informa uma grande recorrência do debate sobre as políticas públicas e o direito à educação de populações empobrecidas e as implicações da alfabetização, enquanto existe uma menor produção de pesquisas voltadas para o segmento investigado neste trabalho, os anos finais da EJA, isto é as $3^{\mathrm{a}}$ e $4^{\mathrm{a}}$ Etapas, equivalentes ao Ensino Fundamental II da escolarização regular. Trata-se de estudantes já alfabetizados ${ }^{19}$ que estão se familiarizando com as disciplinas ensinadas de forma mais específica, como é o caso da língua inglesa ${ }^{20}$.

Segundo Haddad e Di Pierro (2000), o histórico da educação de adolescentes e adultos é iniciado já no período do Brasil-Colônia, marcado pela atuação dos jesuítas nesse campo e seu caráter missionário e evangelizador. Tais religiosos também ensinavam normas de comportamento e conhecimentos dos ofícios necessários para o funcionamento da colônia, em especial aos índios e, mais tarde, aos escravos africanos. Posteriormente, os jesuítas se encarregaram dos ensinamentos de humanidades aos colonizadores e aos seus filhos.

A garantia legal de escolarização básica para todos é inaugurada, de acordo com os autores supracitados, sob forte influência europeia, por meio da Constituição de 1824. As garantia legal, conforme Ghiraldelli (2003), prevê um sistema nacional de educação: escolas primárias, ginásios e universidades. Ainda assim, manteve-se o descompasso entre necessidades e objetivos propostos, dada a insuficiência de professores, de escolas e de uma organização mínima para a educação nacional. Voltando a Haddad e de Di Pierro (idem), o sistema de educação desse período não passou de uma formalidade legal,

(...) porque, em primeiro lugar, só possuía cidadania uma pequena parcela da população pertencente à elite econômica à qual se admitia ministrar educação primária como direito, do qual ficavam excluídos negros, indígenas e grande parte das mulheres. Em segundo, porque o ato adicional de 1834, ao delegar a responsabilidade por essa educação básica às Províncias, reservou ao governo

\footnotetext{
${ }^{19}$ Refiro-me à expectativa de alfabetização nas $1^{\mathrm{a}}$ e $2^{\mathrm{a}}$ Etapas da EJA, embora tenha observado, entre as comunidades investigadas, que o domínio da tecnologia da escrita ainda não estava completo para todos os estudantes, como nos sugere a fala de uma aluna da $3^{\text {a }}$ Etapa, ocorrida durante uma aula: "D: Sabe o que acontece? É que...Eu num sei. Eu, assim, que nem... Pra mim, eu acho que eu tenho que primeiro começar a ensinar as letras, qual que é as letras. Ainda não me ensinou qual que é as letras. Primeiro tinha que ter ensinado as letras. Mas assim, eu nunca fui na escola."

${ }^{20}$ A ênfase na alfabetização em língua materna é notada não apenas nas pesquisas, mas também surge nas entrelinhas das comunidades investigadas.
} 
imperial os direitos sobre a educação das elites, praticamente delegando à instância administrativa com menores recursos o papel de educar a maioria mais carente. O pouco que foi realizado deveu-se aos esforços de algumas Províncias, tanto no ensino de jovens e adultos como na educação das crianças e adolescentes. (HADDAD; DI PIERRO, idem, p. 109, grifo nosso)

A Constituição de 1891, formulada durante a Primeira República, acentuou a concepção de federalismo em que a responsabilidade pela educação básica foi descentralizada nas províncias e municípios. À União ficou a responsabilidade pelo ensino secundário e superior, mais uma vez demonstrando a prioridade em formar uma elite do que em atender às camadas populares em sua formação básica. Isso porque restringia a oferta de ensino básico como responsabilidade das províncias, que não tinham sustentabilidade financeira para fazê-lo - e também essas por serem controladas, por sua vez, por oligarquias regionais (HADDAD; DI PIERRO, idem).

A partir de 1940 é que a educação de adultos passa a ser uma preocupação distinta para fundamentar o pensamento pedagógico e políticas educacionais necessários como um segmento específico (HADDAD; DI PIERRO, ibid.; FÁVERO, 2009). Fávero (2009) pontua que o censo de 1940 indica altos índices de analfabetismo, cerca de 55\% da população brasileira com idade superior a 18 anos. As comparações entre os índices educacionais do Brasil em relação à América Latina começam a apontar para a necessidade de pensar a educação como uma preocupação primeira. Tal preocupação também deriva, segundo Haddad e Di Pierro (ibid.), dos processos de mudança provocados pelo início da industrialização e da aceleração da urbanização brasileiras. Fávero (idem) acrescenta, ainda, às razões para uma tomada de posição do Estado, o movimento de redemocratização do Brasil após a ditadura de 1937-1945 e as iniciativas da recém criada UNESCO, em 1945, que sucedeu a Segunda Guerra Mundial. Os relatórios da UNESCO alertavam para as desigualdades e para o papel da educação, em especial a educação de adultos, "no processo de desenvolvimento de nações categorizadas como "atrasadas" (HADDAD; DI PIERRO, ibid., p. 111). Como se pode observar na literatura da área, notadamente o estudo de Ventura (2013), a UNESCO vê na Educação de Jovens e Adultos um referencial estratégico de desenvolvimento a diversos países a partir de então, sendo as Conferências Internacionais de Educação de Adultos (CONFINTEAs), ocorridas a cada década, sua principal ferramenta nesse sentido (IRELAND, 2013).

Entre 1940 e 1950, as taxas de analfabetismo se reduzem, porém os níveis de escolarização da população permanecem abaixo da média em comparação com os países vizinhos na América Latina. 
O período de 1959 a 1964 é considerado por Haddad e Di Pierro (ibid.) como o período de luzes para a educação de adultos. O congresso de educação de adultos de 1958 repercutiu uma nova visão da pedagogia para com adultos, que se distanciava do pensamento pedagógico voltado para crianças e que por vezes estigmatizava o adulto analfabeto como um ser imaturo e ignorante. Segundo Fávero (ibid.), Paulo Freire, um dos relatores do estado de Pernambuco para a confecção do relatório nacional desse congresso, reflete sobre a educação de adultos e as populações marginalizadas propondo o enfrentamento dos problemas sociais, tornando-o o ponto de partida para o processo educativo. Fávero (ibid.) também menciona o papel da Igreja Católica em tal período, atuando em defesa do equilibrado desenvolvimento das variadas regiões brasileiras, em especial o Nordeste.

O período de luzes é apagado com as intervenções dos governos militares, a partir de 1964, com um "espírito modernizador" e repressor dos movimentos de contestação (SARTORI, 2011) e da educação popular (GHIRALDELLI, idem). Nesse sentido, Sartori (2011) salienta que o analfabetismo é tratado como um problema a ser enfrentado por conta das exigências da industrialização e de sua consequente demanda por uma mão de obra mais qualificada. Daí é que surge o Movimento Brasileiro de Alfabetização (MOBRAL), iniciado em 1968 e extinto em 1980, com o propósito de promover alfabetização universal aos brasileiros, deslocando o teor político da EJA. Ghiraldelli (ibid.), afirma, a esse respeito, que, para se fazer passar por eficaz, os idealizadores do MOBRAL chegaram mesmo a dizer que poderiam utilizar-se do "método Paulo Freire desideologizado", o que parece absurdo, dado que o método Paulo Freire autêntico não poderia conviver com uma educação que não estivesse ligada à ideia de tomada de consciência política a partir da constatação e denúncia do modelo econômico concentrador de renda que, de fato, atingiu duramente justo a clientela do MOBRAL (GHIRALDELLI, ibid., p. 130). Em avaliação sobre o MOBRAL, Paiva (1982, apud FÁVERO, ibid.) relata que em seus dez anos de atuação, reduziu não mais do que 7\% da taxa de analfabetismo, levando-a à conclusão de que "o problema não é o analfabetismo e alfabetizar não é a solução". Fávero (ibid.) ressalta que o problema do analfabetismo tem raízes profundas na sociedade injusta e desigual e questiona que ensino, hoje universalizado no Brasil, é oferecido às camadas pobres da população. Além disso, acentua a articulação entre o período da alfabetização e as outras etapas, configurando a educação básica de forma completa. Entendemos que esta pesquisa possa, portanto, contribuir nesse sentido.

Retomando esse breve histórico, Moura (2007) afirma que é em meados da década de 1980 que os conceitos de letramento passam a se articular à alfabetização na Educação de 
Adultos, por influência dos trabalhos de Mary Kato (1986), Leda Tfouni (1988) e, mais tarde, Angela Kleiman (1995) e Magda Soares (2000). Essas autoras introduzem, no Brasil, os movimentos de estudos de letramento de Brian Street (1983), realizado nos Estados Unidos, trazendo à tona o elemento ideológico, social e de relações de poder imbricados nos atos de escrita e de fala e que posiciona os sujeitos na dinâmica social (MOURA, idem).

Resultante do processo de redemocratização do país no período posterior aos governos militares, a Lei de Diretrizes e Bases da Educação Nacional (LDB), de 1996, nos parece refletir esse novo parâmetro educacional garantindo um avanço histórico para a EJA ao incorporá-la à Educação Básica. Com isso, a EJA deixa de ser entendida como educação supletiva, desconexa do ensino regular (SARTORI, ibid.). Para este autor, atualmente, a concepção proposta para a EJA é a busca por metodologias que não venham novamente a repetir o processo de fracasso escolar, muito menos formas aligeiradas de reprodução e adequação de conteúdos trabalhados no ensino fundamental ou médio, com os sujeitos, nas suas respectivas idades/séries correspondentes.

O Parecer CNE/CEB 11/2000 ressignifica a concepção de EJA (BRASIL, 2000) tomando os conceitos de educação ao longo da vida para embasar a educação para além do processo de certificação, valorizado pelos exames supletivos de outrora. Essa "nova concepção" ${ }^{21}$ oportuniza condições para que o indivíduo se torne capaz de continuar aprendendo independente da conclusão de uma determinada etapa de ensino (SARTORI, ibid., p 68).

Partindo da concepção de educação ao longo da vida, o Parecer CNE/CEB 11/2000², sob a relatoria de Cury, apresenta (apud SARTORI, ibid., p.69-76) três funções para a EJA:

a) Função reparadora: busca reparar o direito negado a tais sujeitos, reconhecendolhes a compensação ao conhecimento de que foram privados, o que os excluiu de determinadas comunidades simbólicas. Reconhece que o acesso ao conhecimento sempre teve papel significativo na estratificação social, o que se acentua na medida em que novas exigências intelectuais adentram a vida cotidiana.

\footnotetext{
${ }^{21}$ Utilizo aspas pois, de acordo com Ventura (2013, p.8), o conceito de educação ao longo da vida não é novo, mas recupera o sentido de educação permanente, já presente no Relatório Aprender a Ser (Relatório Faure), de 1972, desenvolvido pela Comissão Internacional para o Desenvolvimento da Educação, criada pela UNESCO.

${ }^{22}$ Cf. Conselho Nacional de Educação. Parecer CNE/CEB 11/2000. Diretrizes Curriculares Nacionais da Educação de Jovens e Adultos . Brasília, 2000.
} 
b) Função equalizadora: visa a dar cobertura a trabalhadores e a outros segmentos sociais desfavorecidos, cuja permanência no sistema escolar foi interrompida pela evasão ou pela repetência, como donas de casa, população carcerária, migrantes, dentre outros, de modo a garantir uma distribuição e alocação dos bens sociais para obter mais igualdade na rede de conflitos da sociedade.

c) Função qualificadora: reconhecida como a função permanente da EJA, baseia-se no caráter incompleto do ser humano, que se atualiza dentro e fora dos quadros escolares, de forma ampla. Indica que em todas as idades e em todas as épocas da vida, como se acentua pelo emprego do termo "jovens e adultos", é possível se formar, desenvolver e construir conhecimentos, habilidades competências e valores que transcendem os espaços formais da escolaridade e conduzam à realização de si e ao reconhecimento do outro como sujeito. (BRASIL, 2000, p.10-11 apud SARTORI, ibid., p. 74-75).

O estabelecimento da função qualificadora cumpre a superação da visão de que a EJA tem por objetivo suplementar ou recuperar um tempo perdido da vida dos educandos, que não aprendem apenas em um período da vida que se concentra na infância e na adolescência, mas durante toda a vida, conforme os preceitos defendidos pelo conceito de educação ao longo da vida, internacionalmente difundido como life long learning . É importante realçar, entretanto, que a ciência carrega discursos que reforçam visões de interesses a determinados grupos, com a vantagem da neutralidade e do status de verdade. Com a premissa do life long learning, por um lado, ganha-se liberdade na EJA para que se trabalhe com princípios de autonomia e agência. Por outro lado, mascara-se o fato de que o adulto que não estudou enquanto era criança e adolescente foi excluído de diversas oportunidades e recursos simbólicos e econômicos disponíveis a quem domina o capital cultural ofertado pela escolarização. Nessa perspectiva, o life long learning pode suavizar uma situação de exclusão vivida pelo aluno de EJA, independente dos motivos e contingências que o situam nesta modalidade de ensino.

Em uma outra linha interpretativa, o life long learning nos parece interconectado ao capitalismo veloz e global, que requer não apenas mão de obra, mas consumidores qualificados: pessoas flexíveis que estejam em prontidão para o consumo rápido e a agilidade nas relações, sejam elas situadas na comunidade em que vivem ou em seu trabalho, família e amigos, o que requer a abertura e a flexibilidade para aprender coisas novas, o que as leva a consumir não apenas produtos novos, mas a consumir formatações de estilos e modos de ser no mundo novos. Conforme a crítica de Ventura (2013) à adoção desse conceito, que se 
acentuou no decorrer da última década nas pesquisas educacionais em EJA no Brasil, conformando-se às orientações da UNESCO, a proposta de educação ao longo da vida não tem como horizonte um rompimento com a lógica social capitalista. Antes disso,

(...) funciona simultaneamente como um dos mecanismos de resposta aos desafios econômicos contemporâneos, como um dos principais instrumentos de moderação dos efeitos mais extremos da mundialização e como artefato de hegemonia. (VENTURA, idem, p. 13)

Ciente das críticas e dos perigos em relação à concepção de educação ao longo da vida, Faria (2014) pondera que uma abordagem mais profícua, em vez de adotar o lado da crítica negativa que suprime suas possibilidades, é explorar-lhe e debater-lhe os diferentes propósitos e contextos de aplicação. Embora o conceito respeite a individualidade das trajetórias dos sujeitos, é preciso atentar para os projetos de sociedade que ela pode favorecer, que são vários (FARIA, idem, p.33). Portanto, a pesquisadora concorda com a posição de Lima (2007), citado abaixo:

Procuro, assim, compreender as mutações que vêm ocorrendo neste campo, as ambiguidades e as contradições resultantes de distintas perspectivas políticas e sociais que em torno do conceito polissêmico de educação ao longo da vida têm sido construídas, chamando a atenção para o seu potencial democrático, mas também para as derivas economicistas e tecnocráticas já amplamente subordinadas à empregabilidade e à performatividade competitiva. (LIMA, 2007, p. 86 apud FARIA, ibid., p. 33).

Dentro do lócus desta pesquisa, as teorias de letramentos (novos letramentos, multiletramentos, letramento crítico), não poderíamos deixar de acentuar o olhar crítico sobre os discursos e as práticas pedagógicas, entendo-os imbricados em um contexto permeado por relações desiguais de poder. Ainda que não estejamos cientes, estamos posicionados por essas falas, assumindo-as em nossas práticas, conforme o defende Freire (1982) com o termo práxis, que traduz a relação entre a ação e o pensamento. É por isso que, com Janks (2014), inspirada em Freire, se fazem necessárias críticas diante de qualquer análise sobre as visões e práticas pedagógicas que abordamos, todas derivadas da questão "Aos interesses de que quem tal posição serve?":

Quem se beneficia e quem se prejudica com tal posição? Quem ela inclui? Quem é excluído por ela? Como tal situação, a pessoa, ou a ação se construiu? Há 
outras maneiras de se interpretar o ocorrido? Quais são as possíveis consequências sociais dessa visão de mundo? (JANKS, 2014, p.1, tradução nossa ${ }^{23}$ )

${ }^{23}$ Do original: "Who benefits and who is disadvantaged by the position on offer? Who does it include? Who does it exclude? How has the situation or the person or the action been constructed? Are there other possible ways of interpreting what took place? What are the possible social consequences of this view of the world?" 


\section{CAPÍTULO 2 \\ DISTANCIAMENTOS ENTRE O LETRAMENTO SOCIAL E O LETRAMENTO ESCOLAR NA LÍNGUA ESTRANGEIRA}

\subsection{Introdução}

Dentre os variados desafios implicados em ensinar e aprender inglês no programa EJA está o alinhamento entre aprendizagens e conhecimentos desenvolvidos pelos educandos ao longo da vida, os letramentos sociais, e as aprendizagens e conhecimentos escolares, os letramentos escolares. Por entendermos a centralidade desse alinhamento para o desenvolvimento de um trabalho significativo para os alunos da modalidade EJA é que dedicamos este capítulo à discussão de algumas de suas facetas, conforme observadas em nosso trabalho de campo.

Com esse intento, reservamos este capítulo para a discussão de situações de aprendizagem em que o diálogo entre ambos os tipos de conhecimentos ocorre de forma problemática. No capítulo seguinte, debateremos situações em que esses foram contemplados de maneira mais frutífera.

Evidente que nosso intuito nesta pesquisa não é avaliar, de forma alguma, o trabalho das professoras colaboradoras, ou suas escolhas, materiais e abordagens. Antes disso, julgamos que um dos papeis da pesquisa etnográfica em educação e letramento seja o de compreender o máximo possível a respeito das relações pedagógicas, observadas ao longo do trabalho (HEATH e STREET, 2008).

As observações possibilitaram o contato com inúmeros momentos de proveitoso diálogo entre os conhecimentos de vida e os conhecimentos escolares dos estudantes, ao mesmo tempo em que, em outros, os distanciamentos entre esses conhecimentos foram mais notados e acentuados. Por entendermos a importância dos equívocos para amparar a reflexão e o planejamento de novas ações que possam aprimorar as práticas pedagógicas é que eles serão apresentados e discutidos neste capítulo.

\subsection{Intersecções entre letramentos escolares e sociais}

Ao discutir as implicações do letramento social para a aprendizagem de leitura e escrita, Soares (2003) advoga a favor da oferta de atividades de letramento, isto é, de práticas sociais de leitura e de escrita no ensino de leitura e escrita na escola, ponderando que, de 
alguma maneira, a escola tende a autonomizar as atividades de leitura e de escrita em relação a suas circunstâncias e seus usos sociais, criando seus próprios e peculiares eventos e práticas de letramento.

A autora ainda expõe a hipótese de que letramento escolar e letramento social, embora situados em diferentes espaços e em diferentes tempos, componham os mesmos processos sociais mais amplos,

(...) o que explicaria por que experiências sociais e culturais de uso da leitura e da escrita proporcionadas pelo processo de escolarização acabam por habilitar os indivíduos à participação em experiências sociais e culturais de uso da leitura e da escrita no contexto social extra-escolar. (SOARES 2003, p. 14)

Por acreditarmos que a ressignificação do letramento social beneficia o desenvolvimento de letramento escolar, neste capítulo, discutiremos situações de aprendizagem, coletadas nas duas comunidades escolares observadas, em que se acentuaram os efeitos dessas duas esferas do letramento.

Ao defender que a importância dos conhecimentos extraescolares no contexto das tecnologias digitais do início do século XXI, notadamente aqueles desenvolvidos em comunidades de afinidade online e por meio de jogos de videogame, Magnani (2011) ressalva que a instituição escolar não é capaz de incorporar os conhecimentos e as práticas do contexto extraescolar de forma plena e inequívoca. Isso ocorre porque a todo trabalho de sala de aula precedem-se recortes, reduções e traduções. Assim, quando se deslocam esses conteúdos de um contexto a outro, do extraescolar para o escolar,

(...) o objeto se transforma, o enunciado já e outro, as razões e as motivações de cada agente também mudam, regidas pela dinâmica da sala de aula, dos pressupostos pedagógicos e das relações sociais e de poder que previamente existem nesse segundo espaço. (MAGNANI 2011, p. 10)

Considerando o desafio em torno do deslocamento entre os diferentes contextos de aprendizagem e letramento, Kalantzis e Cope (2005) sugerem que, em vez de tratar as duas formas de aprendizagem como dicotomias, sejam abordadas como elementos que podem e dever ser sobrepostos. Desse modo, quando combinadas de forma eficiente, a aprendizagem formal e a aprendizagem informal podem colaborar para a constituição de aprendizagens poderosas para as necessidades do mundo contemporâneo, levando-se em conta a questão das diferenças, evidenciada nos aspectos políticos, econômicos e culturais da globalização e da comunicação via tecnologias digitais.

Kalantzis e Cope (2005) salientam que apenas reconhecer diferenças não implica em aprendizagem, alertando para o risco de uma "abordagem de museu" frente às diferenças, ou seja, buscar reconhecê-las para depois paternizá-las. 
Aprender é mais do que isso, é não ficar onde já se está. É uma jornada para longe da zona de conforto, longe das limitações da experiência de mundo. Não é apenas reconhecer identidades e pertencimentos, mas é também um processo de viajar para longe do familiar, da experiência mundana. É uma viagem de transformação pessoal e cultural, conforme apontam Kalantzis e Cope (idem).

No intento de auxiliar na tarefa de alinhar conhecimentos de mundo e escolares para maior significado das aprendizagens nas escolas, os autores propõem duas condições para sua ocorrência. A primeira delas é o pertencimento, isto é, o engajamento das identidades, interesses e experiências dos aprendizes na ação educativa. Justamente por envolver subjetividades e identidades construídas ao longo da vida é que é importante considerar a diferença na questão do pertencimento. A segunda condição é a transformação, uma vez que, de acordo com os autores, a aprendizagem efetiva leva o aprendiz a um jornada por terrenos desconhecidos. Entretanto, para a aprendizagem se realizar, essa jornada depende de uma certa consonância com uma zona de conforto e segurança, já defendida por Vygotsky (1978 apud KALANTZIS e COPE ibid.), em uma justa medida entre o novo e o repertório do aluno (KALANTZIS e COPE ibid., p. 51).

Observa-se, assim, a consideração desse alinhamento não como uma tarefa de silenciamento de um tipo de conhecimento para o privilégio do outro, mas de um constante e frutífero diálogo que resulta em maior significado do trabalho em sala de aula. Quando o tratamento do conteúdo desenvolvido em sala de aula favorece as associações entre o "mundo fora da sala de aula", a aprendizagem é, além de significativa, transformadora e proporciona ao educando sair de seu lugar familiar para dialogar com outros mundos, conforme a ênfase recolhida das Expectativas de Aprendizagem para EJA (SÃO PAULO, 2007a):

Sem desconsiderar as necessidades imediatas dos educandos - ao contrário, tomando-as como ponto de partida -, a ação educativa deve promover a superação desta situação e avançar na percepção de formas mais elaboradas do conhecimento (SÃO PAULO, 2007a).

A ênfase na necessidade do diálogo entre os conhecimentos formais, próprios da escola, incorporados pelos docentes, e os conhecimentos informais dos alunos, construídos em eventos e práticas de letramento social é central ao trabalho de Paulo Freire $(1982,1997)$ e se sintetiza na afirmação abaixo:

É preciso que o(a) educador(a) saiba que o seu "aqui" e o seu "agora" são quase sempre o "lá" do educando, mesmo que o sonho do(a) educador(a) seja não somente tornar o seu "aqui-agora", o seu saber, acessível ao educando, mas ir mais além de seu "aqui-agora" com ele ou compreender, feliz, que o educando ultrapasse 
o seu "aqui", para que este sonho se realize tem que partir do "aqui" do educando e não do seu. No mínimo, tem de levar em consideração a existência do "aqui” do educando e respeitá-lo. No fundo, ninguém chega lá, partindo de lá, mas de um certo aqui. Isto significa, em última análise, que não é possível ao(a) educador(a) desconhecer, subestimar ou negar os "saberes de experiência feitos" com que os educandos chegam à escola (FREIRE, 1997, p. 31)

Com esse diálogo, necessário à prática educativa, Freire $(1982,1997)$ acentua que os estudantes se beneficiam com oportunidades de conhecer outras posições e outras possibilidades de atuar no mundo, outros "lás".

Conforme pontua Freire (2005, p.177), a sabedoria popular, construída na cotidianidade e na experiência dos indivíduos, guarda uma relação dialética com os saberes científicos, ambos construídos por indivíduos situados na realidade sócio histórica, o que contraria o recorrente entendimento de que a ciência existe independentemente das pessoas. Para Freire, o que diferencia esses dois tipos de conhecimento é a "curiosidade epistemológica" (FREIRE, idem, p. 178), isto é, uma curiosidade programada para observar e conhecer um determinado objeto de forma distanciada da experiência cotidiana. Sem esse tratamento epistemológico, de consciência e controle sobre o ato de conhecer um determinado objeto da realidade cotidiana, o conhecimento permanece na esfera do "senso comum", operado de forma ingênua (FREIRE, ibid.).

Dentro da perspectiva dos estudos de letramento, em específico a vertente do letramento crítico, não há distinção entre saberes superiores ou inferiores por si só. Antes disso, todo conhecimento é em si um elemento complexo e sofisticado. O que ocorre para que se cumpram distinções entre os conhecimentos é um processo de valorização dentro de práticas socialmente construídas de atribuição de sentidos, em que se refletem relações de poder, conforme explicita Jordão (2013, p. 80). Nesse sentido, o conhecimento é um "saber construído socialmente e sempre ideológico, incompleto, deslizante, múltiplo e relativo; é saber sempre passível de contestação, questionamento e transformação" (JORDÃO, idem, p. $81)$.

\section{3 Levantamento de expectativas de aprendizagem na EJA}

Para iniciar a discussão, façamos uma breve contextualização a respeito dos objetivos e expectativas educativas da modalidade EJA. Para tal, explicitamos alguns trechos de documentos norteadores, quais sejam, Diretrizes Curriculares Nacionais para a Educação Básica (BRASIL, 2013); Orientações Didáticas: Alfabetização e Letramento - EJA e MOVA (SÃO PAULO, 2007a), Orientações curriculares: expectativas de aprendizagem para 
Educação de Jovens e Adultos (SÃO PAULO, 2007b) e Caderno de orientações didáticas para EJA Língua Estrangeira -Inglês: etapas complementar e final (SÃO PAULO, 2010).

De acordo com esses documentos, os objetivos gerais da EJA, seguindo a sua organização em etapas, são os seguintes:

\begin{tabular}{|l|l|}
\hline $\begin{array}{l}\text { I: Etapa } \\
\text { Alfabetização: }\end{array}$ & $\begin{array}{l}\text { Espera-se que, ao final desta etapa, o educando disponha de conhecimentos } \\
\text { formais e práticos, em especial no que concerne à leitura e escrita e ao cálculo } \\
\text { matemático, que lhe proporcionem suficiente domínio de tarefas imediatas pela } \\
\text { escrita das esferas relativas à administração da vida cotidiana, do trabalho e do } \\
\text { estudo, bem como do âmbito da sociabilidade imediata, tais como, as relações } \\
\text { que se estabelecem em posto de saúde, igreja, delegacia, comércio, escola etc. }\end{array}$ \\
\hline II: Etapa Básica: & $\begin{array}{l}\text { Esta etapa deve ser considerada como continuação do processo iniciado na fase } \\
\text { de alfabetização, em que os saberes relativos à cultura escrita, à matemática, às } \\
\text { formas de sociabilidade e de conhecimento formal podem ampliar a autonomia } \\
\text { da pessoa e a compreensão crítica do mundo moderno. }\end{array}$ \\
\hline III: Etapa & $\begin{array}{l}\text { A etapa complementar representa um momento da ação educativa em que se } \\
\text { torna possível ao educando, em função dos conhecimentos adquiridos e das } \\
\text { vivências realizadas nas etapas anteriores, ampliar habilidades, conhecimentos e } \\
\text { valores que permitem um processo mais amplo de participação na vida social. }\end{array}$ \\
\hline IV: Etapa Final: & $\begin{array}{l}\text { Nesta etapa, torna-se possível o desenvolvimento de formas de conhecimento } \\
\text { que permitem ao educando jovem e adulto participar e intervir mais agudamente } \\
\text { na vida social, conhecimentos que transcendem a dimensão do cotidiano } \\
\text { imediato, ainda que se relacionem com ele de múltiplas maneiras. }\end{array}$ \\
\hline
\end{tabular}

(Fonte: SÃO PAULO, 2007a)

Quanto à língua estrangeira, cujas aulas são ofertadas a partir da Etapa Complementar, dispõem-se as seguintes expectativas de aprendizagem, segundo o Caderno de orientações didáticas para EJA Língua Estrangeira - Inglês: etapas complementar e final (São Paulo 2010).

\begin{tabular}{|c|c|}
\hline \multicolumn{2}{|r|}{ Expectativas de Aprendizagem de Língua Estrangeira na EJA } \\
\hline $\begin{array}{l}\text { Etapa } \\
\text { Complementar }\end{array}$ & $\begin{array}{l}\text { - Vivenciar a experiência com uma língua estrangeira (a relação identidade } \\
\text { - alteridade); } \\
\text { - Refletir sobre os outros loci sociais na sua sociedade e como seria falar } \\
\text { de, falar com ou ouvir a partir desses outros loci (noção de cidadania como } \\
\text { pertencimento crítico a grupos diversos numa coletividade heterogênea); } \\
\text { - Identificar e buscar o sentido de termos e expressões oriundas de outras } \\
\text { línguas presentes no uso cotidiano no Brasil; } \\
\text { - Avaliar a presença de elementos de outras línguas na cultura brasileira e } \\
\text { na língua portuguesa no Brasil; } \\
\text { - Interagir com comunicação básica (textos escritos, diálogos, relatos) de } \\
\text { outra língua, em situações de cotidiano, reconhecendo seus sentidos e usos } \\
\text { (graus de formalidade; diversidade de gêneros, influências contextuais); } \\
\text { - Conhecer o funcionamento da comunicação (oral, escrita) da língua } \\
\text { estudada, o que inclui: funcões comunicativas, estruturas gramaticais, itens }\end{array}$ \\
\hline
\end{tabular}




\begin{tabular}{|c|c|}
\hline & $\begin{array}{l}\text { lexicais, e adequação comunicativa ao contexto, leitura e construção de } \\
\text { sentidos mediante os contextos; } \\
\text { - Dispor de um vocabulário básico da língua falada. }\end{array}$ \\
\hline Etapa Final & $\begin{array}{l}\text { - Vivenciar a experiência com uma língua estrangeira (a relação identidade } \\
\text { - alteridade); } \\
\text { - Refletir sobre os outros loci sociais na sua sociedade e como seria falar } \\
\text { de, falar com ou ouvir a partir desses outros loci (noção de cidadania como } \\
\text { pertencimento crítico a grupos diversos numa coletividade heterogênea); } \\
\text { - Reconhecer a pluralidade, diversidade e multiplicidade presentes na } \\
\text { sociedade atual (de formas de comunicação, de culturas e identidades, } \\
\text { linguagens, gêneros e modalidades); } \\
\text { - Identificar e buscar o sentido de termos e expressões oriundas de outras } \\
\text { línguas presentes no uso cotidiano no Brasil; } \\
\text { - Avaliar a presença de elementos de outras línguas na cultura brasileira e } \\
\text { na língua portuguesa no Brasil; } \\
\text { - Construir conhecimento de forma condizente com as necessidades da } \\
\text { sociedade (ampliando o foco para a criação com sensibilidade para fatores } \\
\text { contextuais, em contraponto à reprodução, tradicionalmente acentuada); } \\
\text { - Interagir com comunicação básica (textos escritos, diálogos, relatos) de } \\
\text { outra língua, em situações de cotidiano, reconhecendo seus sentidos e usos } \\
\text { (graus de formalidade; diversidade de gêneros, influências contextuais); } \\
\text { - Conhecer o funcionamento da comunicação (oral, escrita) da língua } \\
\text { estudada, o que inclui: funções comunicativas, estruturas gramaticais, itens } \\
\text { lexicais, e adequação comunicativa ao contexto, leitura e construção de } \\
\text { sentidos mediante os contextos; } \\
\text { - Dispor de um vocabulário básico da língua falada; } \\
\text { - Reconhecer, por comparação, diferenças e semelhanças e diferenças } \\
\text { entre o português e a língua estudada (espanhol; inglês), de modo a } \\
\text { contribuir na aquisição de outras línguas; } \\
\text { - Compreender as razões do prestígio das línguas hegemônicas (em } \\
\text { especial do inglês) e os efeitos que este prestígio tem na cultura brasileira. }\end{array}$ \\
\hline
\end{tabular}

(Fonte: SÃO PAULO, 2010)

Observa-se que o título do documento contém o termo didática, que guarda muita recorrência de técnicas e estratégias de ensino que visem à aprendizagem dos alunos. Como se percebe nas diretrizes, não há indícios de quais estratégias devam ser empregadas, mas firmase a consideração dos princípios pedagógicos que as norteiam. Dessa maneira, as diretrizes evocam princípios filosóficos importantes acerca da língua, notadamente o entendimento de que essa se situa em um contexto, cujos significados implicam relações sociais, históricas, culturais e de poder, as quais subsidiam a ação pedagógica que se propõe a preparar o aluno para a vida em uma determinada sociedade. É o que se depreende da seleção da relação de alteridade e identidade proporcionada pela língua estrangeira e da busca por atentar às posições sociais. Postula-se também a compreensão de língua como um fenômeno de múltiplas faces em operação, tais quais as funções comunicativas, as estruturas gramaticais, a 
adequação a um contexto, o léxico, a construção de sentidos em um texto articulada ao contexto, por exemplo. Dessa forma, depreende-se que aprender uma língua é aprender a usála nesses múltiplos aspectos, o que sugere que as atividades pedagógicas, técnicas e abordagens devam contemplar a variedade de aspectos que compõem a língua.

A partir dessas considerações, o documento propõe que o ensino concilie educação e formação dos alunos por meio da aprendizagem crítica e relevante da língua estrangeira, situando-a em um contexto, conforme os pressupostos dos estudos dos novos letramentos (MONTE MÓR, 2013; MENEZES DE SOUZA, 2011; JORDÃO, 2011; GEE, 2004; COPE; KALANTZIS, 2005, 2012; LANKSHEAR; KNOBEL, 2006, 2011, entre outros).

\section{4 Concepções de educação, conhecimento e línguas na exploração de temas norteadores: interdisciplinaridade, transversalidade e transdisciplinaridade}

Segundo os pressupostos em Brasil (2013), a organização curricular na educação básica acolhe abordagens disciplinares, isto é, baseadas em recortes do conhecimento em áreas especificas. Entretanto, a disciplinaridade pode sofrer variadas intervenções epistemológicas, pedagógicas e didático-metodológicas, a saber, a pluridisciplinaridade, a interdisciplinaridade, a multidisciplinaridade e a transdisciplinaridade e requerem atenção por parte da instituição escolar, uma vez que tais intervenções são reveladoras das concepções teóricas que orientam as ações educativas dos professores e o trabalho dos estudantes (BRASIL 2013, p.27) ${ }^{24}$. Ressalta-se, nas referidas diretrizes, que tais conceitos são frequentemente confundidos e praticados de forma equivocada nas escolas brasileiras.

Assim, interessa-nos aqui a interdisciplinaridade e a transversalidade, por figurarem como princípios mais facilmente perceptíveis nas comunidades investigadas. De acordo com Brasil (2013), a interdisciplinaridade é uma abordagem epistemológica que postula a

\footnotetext{
${ }^{24}$ Conforme Landim e Ono (2013), a distinção de Fiorin (2008) é muito útil para a compreensão acerca de três conceitos recorrentes no fazer científico da pós-modernidade: a multi ou pluridisciplinaridade, a interdisciplinaridade e a transdisciplinaridade. À luz da etimologia, compreende-se que os prefixos multi- e pluriindicam abundância qualitativa ou quantitativa. Desse modo, o fazer científico norteado por multi ou pluridisciplinaridade pressupõe que várias disciplinas analisem um dado objeto, sem que haja ligação necessária entre elas. Essa tarefa ocorre paralelamente, o que resultará, ao final, em uma soma de visões sobre o objeto. Já inter- significa "dentro", "entre", o que nos leva ao entendimento de que a interdisciplinaridade pressupõe uma convergência, que de um lado permite transferir conceitos de uma disciplina para outra. Por fim, o prefixo transremete a travessia, deslocamento. Segundo o autor, o fenômeno da transdisciplinaridade ocorre "quando as fronteiras das disciplinas se tornam móveis e fluídas num permeável processo de fusão. [...] Da mesma forma, a transdisciplinaridade é domínio da audácia, que leva a examinar todo o conhecimento.” (FIORIN, 2008, p.38). A distinção entre os conceitos também pode ser encontrada em Brasil (2013).
} 
integração das diferentes disciplinas em um trabalho cooperativo, de abertura para o diálogo entre diferentes sujeitos, saberes, ciências e temas. O diálogo e a integração entre disciplinas ocorrem por meio da transversalidade, organização didático-pedagógica em torno de eixos e projetos temáticos.

Ambos os conceitos de interdisciplinaridade e de transversalidade negam o conceito de conhecimento que assume a realidade como algo estanque, "estável, pronto e acabado" (BRASIL, 2013, p.29). Pelo contrário, o conhecimento construído na pós-modernidade não reconhece fronteiras, mas é flexível, situado (KALANTZIS; COPE, 2012) e se faz na própria ação educativa, o que também leva seus praticantes a lidarem com seus inerentes conflitos.

Um terceiro conceito que merece nossa atenção neste momento é a transdisciplinaridade, frequentemente citada nas diretrizes consultadas, porém não observado nas comunidades investigadas. A transdisciplinaridade pressupõe um trabalho que supera o princípio de disciplinaridade, carregando a noção de trânsito entre as disciplinas, cujos métodos, conteúdos e objetos são ressignificados. A definição de transdisciplinaridade é tratada, de acordo com São Paulo (2007b), junto com Kuenzer (2000), como:

"a construção de um novo objeto, com metodologia peculiar, a partir da integração de diferentes disciplinas, que se descaracterizam como tais, perdem seus pontos de vista particulares e sua autonomia para constituir um novo campo de conhecimento"

(KUENZER, idem, p. 86, apud SÃO PAULO, 2007b, p. 32).

A recorrência à transdisciplinaridade nas aulas de EJA se justifica, de acordo com as Orientações Curriculares e Expectativas de Aprendizagem para a EJA (2007b), pelo entendimento de que essa é a perspectiva mais apropriada para alcançar as demandas da educação face ao enfrentamento da realidade. A EJA, assim como qualquer modalidade de educação voltada para o bem público, é uma ação política que permite aos educandos construir conhecimentos que os auxiliarão na compreensão das bases do processo produtivo, permitindo-lhes a participação e a intervenção na vida social. Isto é, as ações educativas têm por objetivo apreender o avanço do saber científico, que determina novas tecnologias, além de promover a crítica social (SÃO PAULO, 2007b, p. 32).

A proposta de ensino integrado entre disciplinas está no centro de propostas educacionais mais recentes, preocupadas com o papel formador da instituição escolar frente às mudanças na organização da sociedade contemporânea (COPE; KALANTZIS, 2005). Organizando-se em eixos temáticos e mobilizações integradas entre as diversas áreas do conhecimento, a proposta contrapõe-se à organização linear e fragmentada dos conteúdos de cada disciplina, prática comum em perspectivas tradicionais de ensino. Por conta disso, tal 
proposta é apontada como um facilitador para os estudantes e pode trazer maiores benefícios para o público de EJA, portador de ricos saberes desenvolvidos ao longo de suas experiências de vida extra-escolares e que devem ser valorizados pela educação escolar, conhecimentos a partir dos quais se pressupõe um trabalho de maior significância para seus participantes. Mais especificamente, tratamos dos conhecimentos e práticas de letramento em língua materna como grandes aliados para a aprendizagem da língua estrangeira, que deixa de ser um conteúdo distanciadamente novo para se tornar um meio de enriquecimento das aprendizagens sobre o mundo e sobre a sua própria língua.

Em ambas as comunidades investigadas, a ação educativa orientada é organizada sob eixos temáticos, conforme sugerem os documentos que regem as expectativas de aprendizagem da modalidade EJA no Brasil e na cidade de São Paulo: Diretrizes Curriculares Nacionais para a Educação Básica (BRASIL, 2013); Orientações Didáticas: Alfabetização e Letramento - EJA e MOVA (SÃO PAULO, 2007a), Orientações curriculares: expectativas de aprendizagem para Educação de Jovens e Adultos (SÃO PAULO, 2007b) e Caderno de orientações didáticas para EJA Língua Estrangeira -Inglês: etapas complementar e final (SÃO PAULO, 2010).

Entretanto, o desenvolvimento de eixos e projetos temáticos nem sempre envolveu ações pedagógicas integradas entre as disciplinas, como veremos no decorrer dessa discussão. Elaboramos o quadro a seguir para cada tema explorado ao longo das observações em cada uma das instituições escolares.

\begin{tabular}{|c|c|c|}
\hline \multicolumn{3}{|r|}{ Centro Educacional Transdisciplinar } \\
\hline Tema $^{25}$ & $\begin{array}{l}\text { Etapa/ } \\
\text { Duração }\end{array}$ & Conteúdos e Atividades \\
\hline $\begin{array}{l}\text { Saúde e } \\
\text { Corpo } \\
\text { Humano }\end{array}$ & $\begin{array}{l}3^{\mathrm{a}} \text { Etapa/ } \\
\text { Um } \\
\text { semestre }\end{array}$ & $\begin{array}{l}\text { - Leitura, discussão e representação visual de pirâmides } \\
\text { alimentares: Inglês } \\
\text { - Leitura e discussão de tabela de informações } \\
\text { nutricionais (vide Anexo } 2 \text { e } 3 \text { ) } \\
\text { - Paul Cézanne, natureza morta e pintura de cesta de frutas } \\
\text { - Vocabulário relacionado a frutas (vide Anexo 5) } \\
\text { - Vocabulário relacionado a alimentos saudáveis (healthy } \\
\text { food) e não saudáveis (junk food) (vide Anexo 1) } \\
\text { - Leitura do texto "O corpo fala quando a boca cala" } \\
\text { - Canções What a wonderful world (vide Anexo 4) e You } \\
\text { are my sunshine (vide Anexo 6). }\end{array}$ \\
\hline Um olhar & $3^{\mathrm{a}}$ Etapa/ & - Leitura e discussão de texto sobre a infância \\
\hline
\end{tabular}

${ }^{25}$ Os temas se entrecruzaram ao longo semestre.

${ }^{26}$ Como a escola organiza as disciplinas em áreas de conhecimento mais abrangentes do que a Língua Inglesa em si, elenquei todas as atividades e conteúdos observados nas aulas de Linguagens e Códigos e grifei aqueles que mais se relacionaram com o tópico desta pesquisa. 


\begin{tabular}{|c|c|c|}
\hline $\begin{array}{l}\text { para dentro } \\
\text { de mim }\end{array}$ & $\begin{array}{l}\text { Um } \\
\text { semestre }\end{array}$ & $\begin{array}{l}\text { - Produção e exposição de brinquedos com materiais } \\
\text { reciclados } \\
\text { - Vocabulário sobre brinquedos } \\
\text { - Leitura da fábula "O Alce e os Lobos" } \\
\text { - Apresentação do Verbo To Be (Vide Anexo 7) } \\
\text { - Perguntar e responder sobre local onde mora }\end{array}$ \\
\hline
\end{tabular}

\begin{tabular}{|c|c|c|}
\hline \multicolumn{3}{|r|}{ Escola Municipal Paulo Freire } \\
\hline Tema $^{27}$ & $\begin{array}{l}\text { Etapa/ } \\
\text { Duração }\end{array}$ & Conteúdos e Atividades \\
\hline Energia & $\begin{array}{l}3^{\mathrm{a}} \text { e } 4^{\mathrm{a}} \text { Etapa/ } \\
\text { Um mês }\end{array}$ & $\begin{array}{l}\text { Discussão }{ }^{28} \text { das perguntas: Where can we find energy? What do } \\
\text { we do without energy? What do we use it for? Can you live } \\
\text { without energy? What's the main kind of energy in Brazil? } \\
\text { What are other kinds of energy? } \\
\text { - Vocabulário relacionado aos tipos de energia } \\
\text { - Elaboração de um portfolio digital com imagens para } \\
\text { representar os tipos de energia }\end{array}$ \\
\hline $\begin{array}{l}\text { Corpo } \\
\text { humano }\end{array}$ & $\begin{array}{l}3^{\text {a Etapa/ }} \\
\text { Duas } \\
\text { semanas }\end{array}$ & $\begin{array}{l}\text { - Desenhar e relacionar vocabulário sobre as partes do rosto e } \\
\text { do corpo (Anexo 10) }\end{array}$ \\
\hline Moradia & $\begin{array}{l}4^{\text {a Etapa/ }} \\
\text { Duas } \\
\text { semanas }\end{array}$ & $\begin{array}{l}\text { - Leitura e desenho de uma planta de casa (Anexo 11) } \\
\text { - Vocabulário sobre os cômodos de uma casa } \\
\text { - Comentar (em português) sobre seu cômodo favorito } \\
\text { - Levantamento de itens que pertencem a um cômodo } \\
\text { - Usar o dicionário }\end{array}$ \\
\hline $\begin{array}{l}\text { Datas } \\
\text { comemorativas }\end{array}$ & $\begin{array}{l}3^{\mathrm{a}} \text { e } 4^{\mathrm{a}} \text { Etapa/ } \\
\text { Uma a duas } \\
\text { aulas }\end{array}$ & $\begin{array}{l}\text { - Leitura, em grupos, de texto informativo (em português) sobre } \\
\text { o Halloween (Anexo 8). } \\
\text { - Discussão acerca das principais informações do texto. } \\
\text { - Canção Strange Fruit (Anexo 9), com atividades de } \\
\text { vocabulário e de compreensão oral, para discutir o Dia da } \\
\text { Consciência Negra. }\end{array}$ \\
\hline
\end{tabular}

\section{Quadro 2}

As concepções de conhecimento, educação e linguagem estão altamente relacionadas, constituindo um diálogo de construção e reconstrução mútuas. Nos termos de Reagan (2009, p. 53),

Seja reconhecida como tal ou não, a linguagem tem efetivamente permanecido como $o$ elemento central que não apenas torna a educação possível, mas que desempenha um papel-chave na construção de conhecimento tanto por parte do aluno quanto por parte do professor. Pressupostos e crenças sobre a linguagem, assim como atitudes em face dela, operam como formas importantes de dar o tom e de estabelecer os parâmetros da experiência educacional, e podem, nos contextos

\footnotetext{
${ }^{27}$ Cada tema foi desenvolvido em aulas específicas, sem entrecruzamento.

${ }^{28}$ Discussão realizada em português entre os estudantes e a professora, que elencava na lousa as respostas em inglês.
} 
escolares, servir tanto a propósitos positivos como negativos. (Tradução da pesquisadora, grifo no original ${ }^{29}$ )

\subsection{Dos eixos temáticos à noção de língua estrangeira como um sistema de vocábulos}

Das situações de aprendizagem observadas durante o trabalho de campo, cinco se destacaram por caraterísticas relacionadas ao tratamento do léxico em língua estrangeira presente nas aulas de EJA. Organizamos as referências a essas situações por meio de títulos, elencados abaixo, para, a seguir, tecer comentários a respeito de cada uma delas.

Grande parte das práticas observadas nas aulas de língua inglesa centralizaram-se no aspecto lexical, daí a nossa seleção neste capítulo. Trataram-se de trabalhos com temas explorados, por meio de discussões orais em língua materna, que ofertaram, em dado momento, vocábulos de língua inglesa.

Veremos que a opção por enfatizar o léxico de língua inglesa na modalidade EJA descaracteriza a multiplicidade da língua. Essa descaracterização se acentua quando se trata da modalidade EJA, devido ao seu inerente aspecto político diante da realidade social de populações que não tiveram acesso ou não puderam concluir as etapas de escolarização na idade dita adequada, o que suscita uma gama de preocupações, tais como o direito ao acesso a aprendizagem de uma língua estrangeira para o exercício da cidadania, a oferta de língua estrangeira como oportunidade para o desenvolvimento da criticidade e a perspectiva de mobilidade social.

As observações feitas são aqui analisadas sob os seguintes subtítulos:

1) A conscientização sobre a energia, da professora Milena;

2) O desenvolvimento de vocabulário sobre partes do rosto e do corpo, conforme observado nas aulas de Milena;

3) O trabalho com os cômodos de uma casa, nas aulas de Milena;

4) O trabalho com questões relacionadas à infância dos estudantes, proposta pela professora Vívian;

5) O trabalho sobre alimentação, por Vívian.

\footnotetext{
29 "Whether recognized or not, though, language has in fact continued to be the central element that not only makes education possible, but which plays a key role in the construction of knowledge on both the part of student and the part of the teacher. Assumptions and beliefs about language, as well as attitudes toward language, function in important ways to color and set the parameters of the educational experience, and can, in the classroom and school contexts, serve either positive or negative ends" (REAGAN, ibid., p. 53)
} 


\subsubsection{A conscientização sobre a energia, da professora Milena}

A primeira situação elencada, conduzida por Milena, figurou como uma parcela de um projeto desenvolvido por toda a escola. De acordo com Milena e a coordenação da escola, o projeto foi uma parceria com uma companhia de energia elétrica que abastece a região onde a escola se localiza, com a meta de alcançar 1600 (mil e seiscentas) escolas nos municípios abastecidos entre 2010 e 2014. Ainda de acordo com Milena e a coordenação da escola, o projeto propõe conscientizar a comunidade escolar para a necessidade de desenvolvimento de ações de sustentabilidade em relação ao consumo de energia elétrica. Dessa forma, diante da proposta, a escola adotou o projeto, embora a adesão a ele não fosse obrigatória por parte dos educadores. Mesmo assim, todos os educadores desta escola aderiram e estavam, à época em que minhas observações iniciaram, atuando nesse sentido. Segundo informações disponibilizadas pela empresa fornecedora de energia elétrica, o projeto sugere a colaboração no sentido de proporcionar o conhecimento de si, do outro e do ambiente; estudar os impactos ambientais da produção de energia; e os recursos naturais, como água, ar e energia.

A opção de Milena para adequar-se às propostas do projeto foi conduzir discussões orais em língua materna, norteadas por questões, registradas por escrito na lousa, em inglês. Dessa maneira, após o registro das questões na lousa, Milena explicava ou traduzia seu significado e, em seguida, estimulava que os alunos respondessem-nas, o que acontecia em português. Além das perguntas norteadoras em inglês, os estudantes foram solicitados a registrar, em seus cadernos, vocábulos relacionados às formas de obtenção de energia disponíveis no Brasil. Cumpre informar que, embora elaboradas na língua inglesa, as perguntas norteadoras das discussões não foram objeto de estudos ou sistematizações nas aulas observadas, mas apenas disparavam as indagações sobre as quais os alunos se engajaram a debater. Dessa maneira, a intersecção entre o projeto da escola, ou seja, o tema macro em desenvolvimento em todas as disciplinas, e as competências micro, específicas à aula de inglês, foi observada no enfoque dado ao vocabulário.

A fim de ilustrar e discutir a respeito do tratamento do tema "Energia", voltado para os vocábulos, reproduzimos abaixo um trecho das anotações de campo da pesquisadora, realizadas in loco, durante observação de uma aula da professora Milena: 


\section{TRECHO 1}

Milena introduz o assunto de energia perguntando o que os estudantes estão estudando em Ciências. Os alunos respondem que estão estudando sobre energia. A professora então escreve na lousa: "Where can we find energy?", com a tradução em português.

A partir disso, os alunos fazem colaborações em português, que são reformuladas pela professora em inglês. Ela anota os exemplos dos alunos na lousa, com a tradução. Além disso, Milena mescla português com inglês em sua fala, com produções como: nosso body; a light que está funcionando, o fan que está desligado. Outros exemplos de expressões que a professora utiliza em inglês: At home, DVD, microwave, computer, radio...

C1.: E o ferro de passar roupa? [E fala para a colega] Hoje passei muita roupa.

M escreve na lousa iron. Pergunta: "E onde vocês trabalham, tem energia? Quem trabalha em indústria?"

C2. fala que em seu trabalho tem um gerador, usado quando a energia acaba.

M. então, pede que os alunos não copiem as perguntas e respostas da lousa, apenas prestem atenção. Diz que depois terão tempo. Escreve na lousa: "What do we do without energy?".

M: "Dá pra watch TV, ouvir o radio? E à noite? O que fazer? Sleep? Não tem a soap opera."

C3: "É que estamos muito acostumados."

M. escreve mais uma pergunta na lousa: "What do we use it for?", com a tradução em português. Conforme alunos respondem em português, M. anota em inglês na lousa: To light our houses. To cook and heat food. To iron clothes.

M. enfatiza a pronúncia de iron. Explica que iron pode ser tanto o "ferro" quanto "passar roupas".

Um aluno pergunta pela palavra "grill" e M. explica que grill é grelhar.

Alunos pedem para copiar. M. autoriza a cópia e mostra na lousa que onde ela marcar X, os alunos devem pular uma linha no caderno.

M. explica que na próxima aula a turma irá ao laboratório de informática fazer pesquisa de vocabulário em conjunto com as aulas de geografia. Um aluno diz "Aí, sim!"

M. sugere escrever no caderno como se fala/se pronuncia as palavras entre barras, para não confundir com a grafia correta.

Anotações do diário de campo - aula na $3^{\text {a }}$ Etapa A (tipos de energia) em 09/10/12

Em primeiro lugar, frisamos que o escopo de abordagens e atividades selecionadas para o trabalho desenvolvido ao longo do projeto da escola acerca da energia nas aulas de inglês foi composto por dois momentos: o primeiro tratou-se da discussão de expressões e vocábulos em torno de fontes de formas de energia e levou cerca de duas a três aulas para ser desenvolvido; o segundo, uma seleção de imagens, disponibilizadas pelo mecanismo de buscas online Google, para a produção de um portfólio de fontes de energia, junto à disciplina de geografia.

Embora diferentes entre si, ambas as atividades enfocam o sistema lexical da língua, tratamento cujos conceitos e implicações serão discutidos nesta seção.

Na primeira parte da sequência didática observada, dedicada à discussão das questões norteadoras em língua materna subsidiada pelas traduções da professora, os papeis empreendidos pela professora e pelos estudantes se assemelhavam aos de um jogo, como em um pingue-pongue em que os alunos demandavam respostas às suas dúvidas sobre a tradução 
de palavras em inglês. Nesse jogo, cabia aos alunos o papel de dar suas opiniões em português, perguntar pela tradução em inglês de palavras que lhe interessassem para, em seguida, anotar esse novos vocábulos e expressões em seus cadernos. Assim, parece muito comum o entendimento de que a ligação entre o inglês e os temas da escola ocorre pelo vocabulário.

Ressalvamos que a atividade em questão foi propensa a um grande envolvimento por parte dos estudantes, dialogando com os conhecimentos de sua realidade. Isso é notável quando consideramos que, embora a quantidade de alunos fosse grande, muitos realmente estavam dispostos a opinar e fizeram questão de que suas posições fossem ouvidas pela professora e pelos colegas. De um lado, a grande conversa coletiva revela que o ambiente é provido de conforto e espaço para que os alunos se sintam à vontade para o diálogo bilateral com a professora. De outro, a aula é toda permeada por conversas e tomadas de posição que talvez colaborem para o desenvolvimento de posturas diante dos problemas enfrentados no dia a dia. É notável a relevância dos problemas do micro para o macro. Reconhece-se que a organização da atividade em torno de uma proposta de reflexão sobre as formas e fontes de energia gerou interesse dos alunos em articular seus conhecimentos prévios, desenvolvidos em suas práticas de letramento social, em meio a suas rotinas, suas atividades de trabalho e suas experiências de vida às palavras e expressões em um outro idioma. Estimulados a buscar conhecer vocábulos que nomeiam elementos de seu dia a dia traduzidos no novo idioma, os estudantes diziam palavras e expressões em português, reformuladas pela professora para o inglês, como se destaca abaixo, do trecho da aula da $3^{\text {a }}$ Etapa A:

\section{A: $\mathbf{E}$ o ferro de passar roupa? [E fala para a colega] Hoje passei muita roupa .}

O que nos chama a atenção no trecho exposto é a concentração da ação educativa, em si própria um recorte que deriva de escolhas, estabelecendo a ênfase em atividades voltadas para o léxico no estudo da língua estrangeira, com a tradução de vocábulos por parte da professora. Com duas atividades voltadas para o léxico, tal organização pedagógica evidencia o tratamento da língua, em ambos os momentos da sequência didática, quais sejam, 1) a discussão sobre fontes e formas de obtenção de energia e 2) a busca de imagens na internet para compor o portfólio de geografia, como um conjunto de vocábulos e expressões que pode ser traduzido e deslocado de um contexto para outro sem quaisquer reflexões ou ponderações quanto a aspectos importantes do contexto e da noção de texto dos quais as palavras são elementos constitutivos. De acordo com Reagan (idem) e Gee (2004), as palavras em si não possuem definições generalizáveis, como as apresentadas em dicionários, aplicáveis a 
qualquer contexto, mas funcionam e se modificam de acordo com eles. Para Gee (idem), conhecer o significado geral de palavras é praticamente inútil se não se souber o emprego delas em contextos. É devido a tal desconsideração às diferenças entre os usos e as traduções de palavras em contextos variados que se pode desenvolver a compreensão de que há equivalências exatas entre os vocábulos, o que pode levar à noção de que os vocábulos e as expressões existem por si só, precedendo seu uso por parte de falantes diferentes em contextos e textos distintos. Tal tratamento distancia-se, por exemplo, da compreensão da linguagem como um fenômeno dotado de variantes, nos modos particulares dos indivíduos em seus falares, como o enfatiza a abordagem da sociolinguística ${ }^{30}$ :

A tentativa de compreender o fenômeno linguístico em toda a sua complexidade levou os estudiosos da área da linguagem a reconhecer que, embora possamos nos referir a uma língua, como o português, por exemplo, estabelecendo uma diferença com outra, vamos supor o inglês, não é possível ignorar o fato de que cada uma dessas línguas, no seu interior, se divide em modos particulares de falar, relacionados aos diferentes grupos sociais, regionais e aos usos que se faz dela. (FARIA; PAULA, 2009, p. 12)

Sem diferenciações ou mesmo breves ponderações sobre os contextos de uso dos vocábulos nas diferentes línguas ou mesmo sem outras atividades em que tais diferenciações pudessem ser evidenciadas, mantém-se a tradicional concepção de linguagem como um sistema abstrato, antecedendo os usuários, e do modelo autônomo de letramento, isto é, destacado de implicações sociais e ideológicas presentes nos textos e nas práticas e eventos de letramento, segundo Street (1983 apud BARTON, ibid.). Ainda de acordo com o autor, o modelo autônomo de letramento é também ideológico, dotado de uma tentativa de mascarar pressupostos ideológicos e culturais para que sejam entendidos como neutros e universais. No contexto da Educação de Jovens e Adultos em específico, em que se trabalha com camadas socialmente desprivilegiadas, o modelo autônomo de letramento pode ainda levar ao nãoquestionamento a respeito das condições sob as quais esses estudantes encontram-se em uma determinada posição social .

Outra questão, também importante de se frisar, é a temida equivalência de termos entre o português e o inglês que os alunos propõem e até mesmo Milena reforça ao utilizar frases mescladas, como se observa abaixo ${ }^{31}$ :

\footnotetext{
${ }^{30}$ Conforme elucidam Faria e Paula, "sociolinguística é a parte da ciência da linguagem que se dedica a estudar as relações entre língua e sociedade, mais precisamente a variação no interior das comunidades de fala." (FARIA; PAULA, idem, p. 13)

${ }^{31}$ Evidente que há debates, entre estudiosos de ensino e aprendizagem de língua estrangeira, em que se concorda que o aprendiz não apenas pode como deve apropriar-se da língua estrangeira de forma emancipadora (RAJAGOPALAN, 2003), desvinculando-se de modelos e referências como os falantes nativos, por exemplo (KUMARAVADIVELU, 2012). Assim, esse usuário pode falar da maneira como quiser expressar-se na língua
} 


\section{"Dá pra watch $T V$, ouvir o radio? E à noite? O que fazer? Sleep? Não tem a soap}

opera."

A equivalência entre os termos pode fazer soar aos alunos uma ideal e asséptica tradução entre termos, que parecem flutuar em um espaço abstrato do certo e do errado, não aceitando as peculiaridades construídas no ato mesmo de usar as línguas, em seus contextos. Da mesma forma, esse tipo de abordagem não aceita a multiplicidade de traduções entre as variadas línguas, que se norteiam pelas implicações contextuais de seu emprego.

Nesse sentido, perde-se de vista o fato de que o deslocamento entre os termos de uma língua vertidos para uma outra são ações posicionadas da professora, um ato de construção de sentidos em que se interpreta um dado objeto. Em outros termos, ao se tratar as línguas como equivalências absolutas e gerais, apaga-se delas o contexto, a vida, a situação, o momento e até mesmo o seu usuário, que, ao traduzir os termos, efetua um ato de interpretação (RICOEUR, 1977) de ambas as línguas. Suas interpretações, sendo ações, têm como pano de fundo a complexidade de implicações do contexto, relações de poder e de conhecimento, em que vive.

Contrapondo-se à ação da professora, nota-se que não é ofertada aos alunos a oportunidade de realizar ou de refletir a respeito das traduções ou das relações contextuais, sócio históricas e de poder subjacentes a elas. Silenciados, os alunos observam a atuação da professora, que demonstra seus conhecimentos como uma especialista no tema (REAGAN, ibid.).

Feita a discussão acerca do primeiro ciclo de atividades sobre formas e fontes de obtenção de energia, tratemos da segunda atividade, dedicada ao desenvolvimento do projeto de conscientização sobre o uso de energia. Essa consistiu, conforme já mencionado, de uma ida ao laboratório de informática com o objetivo de selecionar imagens no mecanismo de buscas online Google Imagens para construir um portfólio em conjunto com a disciplina de geografia e levou uma aula para ser concluída. Os alunos foram informados sobre essa atividade algumas aulas antes. Foi possível perceber reações diferenciadas ao anúncio, muitas delas positivas.

Nessa atividade, a professora listou na lousa as seguintes fontes de energia, nomeadas em inglês:

estrangeira, porque, sem as opressões por obedecer a modelos, a língua passa a pertencer a quem quiser aprendêla e, a partir do momento em que diferentes pessoas passam a aprendê-lo, mais uma vez, elas imprimem, se apropriam dessas regras criando regras próprias, híbridas, construídas da junção entre línguas, inclusive. 


\begin{tabular}{|c|}
\hline Types of energy: \\
Wave power \\
Wind power \\
Biofuel \\
Biomass \\
Geothermal \\
Tidal power \\
Fossil fuels \\
Solar energy \\
\hline
\end{tabular}

A seguir, instruiu os alunos a dirigirem-se para o laboratório de informática, levando seus cadernos, para procurar tais expressões no mecanismo Google Imagens, que busca imagens de páginas da internet a partir de palavras-chave. Sem poder contar com a tradução das palavras e expressões para o português, que a professora propositalmente não ofereceu, nem deixou que buscassem-nas no dicionário, o grande desafio dessa atividade para os estudantes era entender o significado das expressões verbais tendo como recurso os significados das imagens. Isso exigia a observação das variadas imagens fornecidas pelo mecanismo, procurando filtrar e descartar aquelas que não condiziam com o contexto energia.

Deveriam criar um documento de Word, copiar as imagens da internet e colá-las neste arquivo. Ao final da aula, os alunos deveriam salvar o arquivo intitulando-o com o seu próprio nome, sua etapa e a disciplina, "Inglês".

Chegando ao laboratório, notou-se que os computadores já haviam sido preparados para receber os alunos, pois esses já estavam com a página do mecanismo Google Imagens aberta. Ainda assim, alguns alunos pediram ajuda para a professora, para o Professor Orientador de Informática Educativa (doravante POIE) e para mim, alegando nunca terem utilizado o mecanismo de buscas de imagens. Entretanto, fui informada pelo POIE e por Milena de que o uso do mecanismo de buscas Google, que procura conteúdos verbais na web a partir de palavras-chave, é frequente e faz parte dos conhecimentos básicos desenvolvidos nas aulas de informática, disciplina específica que compõe o currículo de $\mathrm{EJA}^{32}$ e do ensino regular do ensino fundamental nas escolas da prefeitura de São Paulo à época da pesquisa ${ }^{33}$.

\footnotetext{
32 À época das observações, nas aulas de língua portuguesa os alunos de EJA também desenvolviam atividades que frequentemente envolviam o uso do laboratório de informática. Como meta inicial, todos os alunos deveriam cadastrar uma conta de e-mail para acessar instruções, tarefas e leituras enviadas pela professora. Movida pelo interesse nas variadas construções de conhecimento dentro e fora da escola, observei uma aula de língua portuguesa em uma das turmas colaboradoras. A atividade constitui-se da leitura de diversos textos informativos a respeito do resultado das eleições municipais ocorridas naquela época.

${ }^{33}$ No Centro Transdisciplinar, onde a professora Vívian leciona, essas mesmas aulas compõem a disciplina intitulada Ensino Profissionalizante e tem por objetivo o ensino das ferramentas básicas de informática, como
} 
A atividade em questão tem o benefício de valorizar a linguagem visual como um elemento de construção de sentidos, com o mesmo status da linguagem verbal, frequentemente priorizada na escolarização tradicional, conforme afirmação de Cope e Kalantzis (2005). Ainda de acordo com os mencionados autores, a preocupação com a multimodalidade, isto é, o emprego e a leitura de recursos semióticos de variados meios reflete a complexidade e a riqueza das novas mídias, vindo ao encontro das mudanças sociais ocorridas nas últimas décadas, em decorrência da expansão das tecnologias digitais de comunicação e informação. Em estudo sobre o letramento visual, notadamente a utilização de filmes para o ensino e aprendizagem de língua estrangeira, Ferraz (2013) compila as principais teorizações da relação entre a imagem e a representação da realidade, enfatizando, em consonância com Gromich (apud FERRAZ, idem), que a imagem é mais do que a mera representação da realidade, ela é um sistema simbólico que é apreendido conforme a experiência e o saber de quem a vê. Aliando-se tal perspectiva às dos estudos de letramento, a compreensão e a interpretação de imagens, da mesma forma como ocorre com o sistema simbólico verbal, implicam-se em um determinado contexto histórico, social e cultural. Ainda nesse sentido, Sartre (1996) aponta para os estudos de imagens dentro de uma perspectiva fenomenológica, isto é, em uma relação entre o ser e o contexto em que esse se insere, donde se entende que a imagem seja um ato no mundo.

Por tais questões acima apontadas, Milena, ao explorar as imagens como forma de compreender os vocábulos sugeridos para a pesquisa, colabora para a mobilização de conhecimentos inseridos nos letramentos sociais dos alunos, uma vez que imagens são compreendidas em contexto, o que se expande para além da situação de sala de aula. Ainda assim, a variedade de práticas pedagógicas ofertada pelo uso de imagens é reduzida à apreensão de palavras e expressões, configurando a coesão entre os conteúdos do projeto geral e os da disciplina de inglês via léxico, reforçado como o principal elemento linguístico desenvolvido em ambas as atividades.

\subsubsection{O desenvolvimento de vocabulário sobre partes do rosto e do corpo, conforme observado nas aulas de Milena}

Para fins de contextualização, ressaltamos que se trata de uma parte de uma aula que compõe uma sequência didática cujo propósito era ensinar vocabulário sobre as partes do

elaboração de documentos de texto e de tabelas, de acordo com os professores que lecionavam a disciplina à época das observações. 
corpo e do rosto. As atividades realizadas nessa sequência ocorreram em três aulas e envolveram o desenho, na lousa, do corpo e do rosto de uma figura simulando um personagem; a exposição de vocábulos sobre o corpo e o rosto; a repetição, em coro, dos vocábulos aprendidos; o registro, nos cadernos, dos desenhos e do léxico para os nomes das partes do corpo e do rosto; na aula final, uma pequena avaliação escrita ${ }^{34}$. Apontando para partes da ilustração do personagem na lousa, a professora indicava ou perguntava à turma os nomes das partes do corpo em inglês. Muitos desses vocábulos eram desconhecidos pela turma, o que resultou, de modo geral, em uma aula expositiva.

\section{TRECHO 2}

M: O que mais nós temos? Nós temos o cotovelo. Alguém sabe como se diz cotovelo em inglês?

D2: Kind.

M: Hum?

D2: Kind.

M: No... É uma palavra que eu gosto, parece uma batata na boca. Fala assim, oh, elbow.

D2: Elbow.

M: Elbow.

D2: Elbow.

Milena: Nada a ver com o português, né...

D2: Elbow...elbow...elbow... elbow...elbow. Elbow Ramalho.[pronunciado ramálhou]

Transcrição de trecho de aula na $3^{\text {a }}$ Etapa B (partes do copro) em 13/11/12

No excerto acima, Milena está ensinando vocabulário relacionado às partes do corpo e pergunta se a turma sabe como dizer "cotovelo" em inglês. Ao receber como resposta uma tentativa de versão equivocada, a professora confirma que o vocábulo equivalente em inglês não se parece com o do português.

Desse trecho, depreendem-se duas questões que demandam reflexões de nossa parte. A primeira delas surge da percepção de que, ao perguntar à turma se alguém sabe como se diz uma determinada palavra em inglês, a professora procura conhecer o que os alunos sabem e, com isso, construir conhecimentos novos baseados naqueles que já lhes são familiares. A estratégia da professora pode certamente figurar como uma sinalização de que um aluno de fato tem a possibilidade de conhecer a palavra e colaborar para uma construção coletiva de repertório linguístico. Porém, seguindo o modelo tradicional de aulas em que o professor elabora perguntas para as quais o aluno tenta acertar ou mesmo "adivinhar" a resposta correta (BARTON, ibid.), como é observável na fala do aluno D2, essa tentativa reforça, por outro lado, o tradicional papel da escola como uma instituição detentora de conhecimentos, que se

\footnotetext{
${ }^{34}$ A avaliação assemelhou-se à atividade realizada em aula. Ante a ilustração de uma figura humana contendo flechas e lacunas, onde se deviam associar as imagens aos vocábulos.
} 
põe a "testar" os alunos e posicioná-los na carência desses. O diálogo entre os conhecimentos do aluno e os da professora é distanciado, dificultando o percurso entre o "aqui" do aluno e o "lá" da professora, conforme os termos de Freire (1997).

A segunda questão que se coloca para reflexão é a da associação entre a língua materna, isto é, a língua familiar aos alunos, e a língua estrangeira, a língua que se estuda durante essas aulas, incentivando-se o estabelecimento de relação entre vocábulos em inglês a vocábulos em português. Tal percepção advém do comentário da professora de que a palavra elbow não se parece com a palavra cotovelo.

Nesse caso, entendemos que o conhecimento de língua materna não é o recurso mais apropriado para a aprendizagem. A insistência em seu emprego possui o efeito de distanciar ainda mais os alunos de seu objeto de estudo, incentivando-os a buscar semelhanças onde elas não existem. Ao dizer que a palavra elbow não se parece com português, entendemos que Milena pode ter encaminhado os alunos a uma expectativa de que as palavras em inglês devam se parecer com as do português, o que não se constata. Pode-se, de uma outra perspectiva, menos problemática, compreender que essa afirmação é uma apreciação das diferenças entre as duas línguas. Parece-nos necessário, nesse caso, apontar para as diferenças entre as duas línguas, conforme pontuam Cope e Kalantzis (idem), ressaltando-as não como uma fonte de conflitos e frustrações, tais como quebras de expectativas, mas como modos de enriquecer e ampliar perspectivas. As diferenças constituem o mundo e exigem determinadas posturas entre os estudantes.

Justamente, no ensino de língua estrangeira, atentar para a diferença, esteja ela localizada em um vocábulo ou em uma visão de mundo nele contida, delineia-se como um de seus objetivos, já explicitados no Caderno de orientações didáticas para EJA Língua Estrangeira -Inglês (SÃO PAULO 2010), ou seja, o de vivenciar a experiência identidadealteridade.

Quanto a isso, Menezes de Souza (ibid.) pontua que por meio do letramento crítico é possível preparar os estudantes para confrontarem-se com diferenças de todo tipo, configurando-se um objetivo pedagógico do mundo contemporâneo, tendo em vista os efeitos da globalização e de sua consequente circulação de diferentes pessoas, ideias e perspectivas pelo mundo. Para o autor, que realiza uma releitura do trabalho de Freire para propor uma redefinição do letramento crítico, o conceito de criticidade se relaciona ao conceito freireano de conscientização, que postula "a compreensão do mundo histórico-social sobre que se está intervindo ou se pretende intervir politicamente" (FREIRE, 2005, p. 242 apud MENEZES DE 
SOUZA, ibid., p. 1). O procedimento para a compreensão do mundo histórico-social é, junto com Freire (2005), "ouvir-se ouvindo", isto é, compreender um texto e suas leituras é uma ação que promove ao leitor uma responsabilidade ativa, de criação e invenção do texto, seguindo o contexto sócio histórico em que ele se insere. Em outras palavras, "ouvir-se ouvindo" significa buscar na realidade sócio histórica as razões para as suas próprias compreensões sobre ela.

Voltando ao trecho selecionado, chama-nos a atenção, por parte do aluno, a repetição do vocábulo, de forma aparentemente desconectada de um contexto. Ele parece estar experimentando os sons desse vocábulo, repetindo-o reiteradamente e provocando um efeito cômico, que se confirma, ao final da intervenção, com sua associação ao sobrenome da cantora Elba Ramalho. É desse ponto que se percebe uma aparente associação entre vocábulos das duas línguas orientada não pelo contexto, mas pelo aspecto fonético isolado.

Parece-nos válido pensar que nesse momento o aluno produz um efeito cômico advindo do distanciamento entre o conteúdo estudado e os conteúdos já conhecidos, uma vez que a única ligação palpável entre eles é a semelhança fonética. Com isso, ele deixou de construir sentidos mediante o contexto, conforme o apontamento das "Expectativas de Aprendizagem de Língua Estrangeira para a EJA” (SÃO PAULO, 2010), ou pelo menos, deixou de conhecer epistemologicamente (FREIRE, idem) o seu objeto de estudo. Apesar disso, sua intervenção nos parece interessante por revelar um certo posicionamento diante da distância entre a abordagem com que é tratada a língua estrangeira e seus conhecimentos de mundo: retoma, a partir da brincadeira e do riso, a familiaridade que parecia não estar vendo em uma palavra isolada de um contexto. Assim, remete a uma palavra que representa algo sobre a sua realidade, isto é, o nome de uma cantora que ele conhece.

\subsubsection{O trabalho com os cômodos de uma casa, nas aulas de Milena}

O trecho foi extraído da sequência de três aulas que tinha por finalidade ensinar vocabulário relacionado aos cômodos de uma casa ou apartamento. Para tal, as atividades foram: desenhar a planta de uma casa imaginária; ensinar, de forma expositiva, de vocábulos que nomeiam os cômodos da casa; comentar sobre seus cômodos favoritos; registrar do desenho da planta da casa e dos novos vocábulos no caderno; listar itens, em português, que se encontram em cada cômodo; consultar o dicionário para obter a tradução dos nomes dos 
itens em inglês; fazer uma pequena avaliação em que se devia nomear os cômodos no desenho da planta de uma casa.

\section{TRECHO 3}

M: Se fosse num apartamento, isso aqui seria uma balcony. O que parece balcony?

B: Balconista.

F1: Balsa.

M: É, lembram que a gente falou sobre os falsos cognatos, sobre palavra que parece mas não é. É, dessa turminha danada. Balcony parece balcão, balconista, mas na verdade é sacada. Mas como é uma casa térrea, a gente deixa assim, nem tem balcony. In English, a gente tem um termo pra quando o quintal fica na frente da casa e um termo pra quando o quintal fica no fundo. Alguém tem ideia de como é que se fala "atrás" em inglês?

[Silêncio]

M: E frente? Parece com português.

F1: Frent?

M: Não tão parecido. É front.

F1: French?

M: Front.

F1: Ah, front.

M: Então eu tenho front yard, que é na frente e backyard. Back é atrás, tá? Backyard é o quintal que fica atrás da casa...

M: [Termina o desenho dos quintais] Quem aqui tem garden em casa?

F1: Gato?

M: Garden.

F2: Jardim.

Segue uma ligeira discussão sobre o que é um jardim, o tamanho, vasos de plantas e temperos.

M: What about... Alguém aqui tem corridor em casa?

F3: Corredor? Ixi, é o que mais tem lá em casa é corredor. A senhora é minha vizinha, né.

Qualquer dia, vai lá em casa tomar um café.

M: Yes! We are neighbors. [Escreve a palavra neighbors na lousa]

[Retoma as outras palavras, backyard, front yard, garden]

M: Aí eu perguntei do corridor... A maioria das casas têm, mesmo as pequeninhas,

normalmente têm corridor. Ah.... Living room... todo mundo aqui tem living room em casa?

Vocês passam muito tempo na living room da casa de vocês?

F4: O que é isso?

M: Sala de estar. Vocês passam muito tempo na living room da casa de vocês?

F5: Não.

M: Onde você fica mais tempo na sua house?

F6: No meu quarto.

M: In your bedroom?

F7: Eu fico muito na cozinha... abrindo a geladeira, essas coisas

[risos]

M: Quem mais fica bastante tempo na living room, na sala de estar?

F8: Por causa da TV.

M: Por causa da TV.

F9: Eu passo mais tempo na laje.

M: Onde?

F9: Na laje.

[risos] 
No trecho observado, os alunos usam o inglês apenas ao praticar exercícios de pronúncia. Enquanto os estudantes comentam em português sobre os vocábulos, a professora os transfere para o inglês, como destacamos em dois momentos representados abaixo:

\section{M: Onde você fica mais tempo na sua house? \\ F6: No meu quarto. \\ M: In your bedroom?}

Observamos, conforme já mencionado anteriormente, a mesclagem de inglês com português na intervenção da professora, o que nos remete à questão da suposta equivalência entre os vocábulos das duas línguas e as implicações que esse conceito envolve.

Enquanto a aluna responde à pergunta da professora em português, a professora parafraseia sua sentença em uma pergunta em inglês. Não se vê a aluna empregar inglês, nem mesmo as palavras que haviam acabado de ser apresentadas pela professora. $\mathrm{O}$ mesmo ocorre no trecho abaixo:

\section{M: What about... Alguém aqui tem corridor em casa?}

F3: Corredor? Ixi, é o que mais tem lá em casa é corredor. A senhora é minha vizinha, né. Qualquer dia, vai lá em casa tomar um café.

M: Yes! We are neighbors. [Escreve a palavra neighbors na lousa]

No segundo excerto, a professora também mescla português e inglês para perguntar se alguém tem corredor em casa, ao que ela obtém de uma aluna a informação de que em sua casa há muitos corredores, seguindo-se o comentário de que elas são vizinhas. Nota-se, com isso, o incentivo aos alunos para que comentem sobre os itens de vocabulário de inglês em sua língua materna, uma possível tentativa de personalização de tais conteúdos lexicais de acordo com a realidade dos alunos. Mesmo assim, essa conversa sobre a realidade dos alunos nos pareceu um trabalho ingênuo, que não ressaltou as aprendizagens ou reflexões a respeito dessa realidade. Fala-se sobre as preferências quanto aos cômodos da casa, aparentemente, para que haja uma memorização do léxico exposto. Ainda que o objetivo dessa rodada de perguntas da professora tenha sido puramente o de fazer com que os alunos se lembrassem dos vocábulos, não houve uma abordagem que estimulasse que os alunos empregassem o inglês, envolvendo- 
se de maneira mais engajada ao que aprendiam. O trabalho restringiu-se a expor aos alunos a um conjunto de palavras dentro de uma aproximação semântica, a casa, mas não notamos uma mobilização frente ao emprego do inglês, fosse ele em uma leitura, uma fala, um jogo, dentre outros. O uso do inglês por parte dos estudantes ocorreu por meio da repetição dos vocábulos e na observação da professora, como um modelo, utilizando esses vocábulos em sentenças que parafraseavam o que os alunos haviam dito em português.

Com tais apreensões, conclui-se que, ainda que estivessem sendo estimulados a comentar sobre um assunto tão familiar, houve distanciamento entre o ensino e a aprendizagem desse conteúdo, por não permitir que os alunos pudessem se engajar de maneira ativa com o inglês, deixando-os a apenas observar a professora, uma especialista (REAGAN, ibid.) fazendo-o.

Esse questionamento encontra uma evidência mais concreta no trecho a seguir. Nele, a professora e a turma são surpreendidos por um aluno que, diante da pergunta da professora, conta à turma que a parte favorita de sua casa é a laje:

\section{F9: Eu passo mais tempo na laje. \\ M: Onde? \\ F9: Na laje. \\ [risos]}

Como a turma ri e a professora não esboça uma resposta, fosse ela similar à intervenção anterior, com uma paráfrase em inglês, ou algo nesse sentido, depreende-se que esse tipo de intervenção por parte do estudante F9 é um desvio do previsto. Por consequência, o que chamamos aqui de desvio desafia a noção de que a utilização do léxico como um sistema fechado, disposto de equivalências entre línguas, é passível de contextualização às identidades dos estudantes, como parece ter sido o objetivo nesse trecho. O paradoxo reside, aparentemente, na expectativa de que comentar a rotina ou a preferência por um cômodo da casa deva coincidir com o emprego apenas das opções lexicais ofertadas, e não fora delas.

Com efeito, toda prática pedagógica, tenha ela esse propósito explícito ou não, tem por finalidade formar um indivíduo para uma determinada sociedade (COPE; KALANTZIS, 2005). Portanto, tratar a expressão/construção de identidades como uma escolha dentro de ofertas lexicais limitadas nos informa a respeito das práticas de letramento escolar como instrumentos formatadores de um certo tipo de sujeito para um certo tipo de sociedade.

Questionamo-nos qual ou como seria esse sujeito que é levado a expressar-se e a agir ou com os recursos de que já dispõe, sem a possibilidade da construção do novo e 
permanecendo em sua posição social, ou com recursos limitados às escolhas de outrem, sem que essa seja uma escolha informada. Em ambos os casos, poucas são as chances de que esse sujeito acredite ser capaz de agir favoravelmente para mudanças de suas condições.

Por estarmos tratando das aprendizagens e letramentos de indivíduos frequentadores da modalidade EJA, cuja trajetória distanciada da escolarização ao mesmo tempo retoma e antecipa o menor acesso a oportunidades de desenvolvimento de capital cultural transformado em capital social e econômico, tal questão é acentuada e ganha a coloração política inerente ao trabalho no programa EJA.

Retomando a principal função do programa EJA, nos termos de Paiva (2005), qual seja, a função qualificadora, estabelecida por meio do Parecer CEB/CNE 11/2000 (BRASIL, 2000), ou seja, de aprender a aprender de modo a desenvolver mais autonomia em suas atividades, a escola tem responsabilidade na contribuição para a (trans)formação de indivíduos aptos a modificar o curso de suas trajetórias, a despeito de injustiças e/ou adversidades decorridas. Atuando favoravelmente nesse sentido ou não, a escola, e as práticas por ela promovidas, corrobora o seu papel como uma instituição que retoma e reforça questões - e desigualdades - presentes na sociedade (BOURDIEU, 1977, 2011).

\subsubsection{O trabalho com questões relacionadas à infância dos estudantes, proposta pela professora Vívian}

Iniciamos essa reflexão partindo da avaliação de Vívian a respeito do trabalho com o léxico, o que se obteve com base em minha questão acerca do trabalho com textos em inglês durante as aulas:

V: Eu amo esse trabalho [com textos]. Eu acho assim, o texto é o que está na vida. Aquele vocabulariozinho, decorar uma lista de nomes de partes do corpo, decorar uma lista de cores, uma lista, ele é necessário também? É! Só que o que que acontece? Quando o aluno recebe essa lista ele acha mais fácil.

Vívian, trecho de entrevista

No excerto, a professora contrasta o letramento social com o letramento escolar, expondo, por um lado, o seu entendimento de que as práticas de letramento social envolvem a lida com os textos, enquanto, por outro, o letramento escolar abrange práticas sistemáticas tais como o estudo de listas de vocabulário. Isso significa dizer que os textos são a materialidade do letramento nas atividades cotidianas (JANKS, 2014), ou, como nas palavras da professora, 
o texto é que está na vida. Já o trabalho isolado de conteúdos como as listas de vocabulário são uma parte necessária para a aprendizagem nos moldes da instituição escolar.

De acordo com Soares (2003), a chamada pedagogização da leitura e da escrita dos eventos e das práticas de letramento - é inerente à escolarização de conhecimentos e práticas e resulta da transposição didática dessas práticas e desses saberes.

Nesse sentido, associamos o referido trecho de entrevista com a seleção de excerto das anotações no diário de campo da pesquisadora referentes à observação de uma aula. $\mathrm{O}$ registro foi produzido in loco e contou com acréscimos realizados posteriormente à aula.

\section{TRECHO 4}

Aula dedicada à comemoração do Dia das Crianças na escola toda, com uma exposição de brinquedos e brincadeiras de crianças no salão principal.

Nas aulas anteriores, Vívian já havia solicitado que os estudantes trouxessem um brinquedo para participar da exposição do Dia das Crianças. A maioria dos alunos já havia trazido suas colaborações ao longo da semana, mas alguns trouxeram no dia da exposição.

$\mathrm{Na}$ aula desse dia, a professora recolhe e elogia os trabalhos.

Em seguida, escreve na lousa: CHILDHOOD, CAR, KIDS, KITE, DOLL, BALL, TOYS, DOLL'S HOUSE. (às 7:34)

V: "Pessoal, deem uma olhada nessas palavras em inglês. O que é KIDS?"

A1: KIDS é criança.

A2: TOY é brinquedo, referente ao filme.

A3: By CAR.

V: Até já estudamos essa palavrinha. Como é que você vai para a escola?

A3: By CAR.

A1: Já vi essa palavra em brinquedo de criança. [Sobre a palavra CHILDHOOD]

$\mathrm{V}$ desenha KITE, DOLL, KIDS, BALL, TOP na lousa.

A4: Pode copiar? (às 7:41)

$\mathrm{V}$ diz que alunos podem copiar.

Às 7:47 subimos para o $3^{\circ}$ andar da escola, para participar da exposição de brinquedos. Lá, há alunos de todas as turmas participando e interagindo com os trabalhos, como os vai-e-vem, bambolês, dominós, feitos pelos próprios alunos, com materiais reciclados.

Às 8:20 Vívian e outras professoras chamam os alunos para fazer uma roda. Tocam a música "Peixe Vivo", interpretada pelo grupo Palavra Cantada.

Ao final da dança, os alunos retornam à sala de aula. Vívian pede aos alunos que se sentem em círculo e pergunta aos alunos sua opinião sobre a atividade. A1 diz que nós não temos tempo de brincar, por isso gostou muito. A5 diz que fazia bambolê de jucá. A6 diz que fazia bonecas de sabugo de milho e de caroço de manga. A7 diz que tinha uma boneca de jornal, deu banho nela e chorou ao ver que tinha estragado. A2: "E mesmo assim a gente era feliz porque era unido, não brigava". A3: As crianças hoje em dia são estouradas. A2. diz que em sua casa eram 12 irmãos. A5 diz que seu filho tem 40 anos e ainda lhe pede a benção. Vivian compara diferentes momentos da educação, enfatizando que antes havia mais rigidez. A5 diz que hoje em dia as crianças brincam com computadores, "as criança parece uns besta". A4: Tem que trabalhar mais porque o custo de vida aumentou muito.

Vívian finaliza pedindo para que os alunos tragam um objeto que remeta à infância. A atividade será demonstrar e comentar (show and tell?). Vívian pede aos alunos que anotem as 
palavras da lousa. Às 9:25 "Vamos tentar falar My favorite toy was......". Fica para homework. Distribui as folhas de homework. .

Anotações do diário de campo - Aula na $3^{\text {a }}$ Etapa A (Dia das crianças) em 10/10/12

Similarmente ao trecho "A conscientização sobre a energia, da professora Milena", discutido anteriormente, o excerto selecionado acima representa um recorte de uma aula de inglês da professora Vívian que se coaduna, via sistema lexical, com um projeto maior desenvolvido pela escola. De acordo com material produzido nas reuniões pedagógicas semanais dos docentes, o projeto, comemorativo do dia da criança, que ocorria na semana em que a aula foi observada, visava a, por um lado, valorizar as identidades dos alunos com leituras e narrativas sobre suas memórias de infância, e, por outro, conscientizá-los sobre a questão da sustentabilidade por meio da reciclagem de materiais já descartados.

Dentro da sequência da aula de Códigos e Linguagens, de acordo com o planejamento semanal disponibilizado pela professora, houve a discussão sobre sustentabilidade; a seleção de materiais reciclados; o planejamento e a confecção de um brinquedo, a exposição de um trabalho próprio; a apreciação de uma exposição de trabalhos dos colegas, a participação em brincadeiras coletivas, a participação em uma ciranda e de cantigas de roda; narrativas de memórias de infância; leitura de um texto sobre a infância; por fim, na área de inglês em específico, uma lista de nomes de brinquedos nesse idioma. Para ensinar alguns desses vocábulos, Vívian fez desenhos na lousa.

Apreendemos que às aulas de Linguagens e Códigos subjaz uma multiplicidade de linguagens e práticas de letramentos sociais e escolares às quais os alunos e professora estiveram engajados. Na área específica do inglês, a multiplicidade não se observa tão marcadamente, embora a estratégia de associar algumas palavras em inglês aos desenhos, provavelmente como forma de facilitar a associação entre o significante e o significado, revele uma preocupação com o emprego de multimodalidade sob os moldes do letramento escolar, conforme já discutido acima.

Nesta aula, diferentemente da aula a respeito das fontes e usos de energia, discutida anteriormente, a professora é quem decide quais as palavras serão colocadas aos estudantes, que deverão associá-las a um significado, ou tradução. O que chamamos de jogo de pinguepongue ocorre entre a professora e os alunos de forma inversa ao que vimos na aula da professora Milena. Neste caso, os alunos devem mobilizar suas estratégias e seus 
conhecimentos de mundo e do idioma estrangeiro para atender às expectativas da escolarização e para engajarem-se à prática de letramento escolar.

Entretanto, atentamos para o fato de que, apesar de o uso de língua estrangeira proposto em sala aula restringir-se a uma prática de letramento escolar, isto é, ao estudo e à discussão de uma lista de palavras, aparentemente isolada dos demais aspectos da língua, com exceção das ilustrações para algumas delas, os alunos explicitam suas estratégias de aprendizagem recorrendo ao letramento social de que dispõem, como é notável nos trechos em destaque:

A2: TOY é brinquedo, referente ao filme.

A3: By CAR.

A aluna A2 evidencia que seu conhecimento da palavra toy advém da situação a um contexto, muito provavelmente o longa metragem norte-americano Toy Story - Um mundo de aventuras (1995), mais conhecido no Brasil pelo título em inglês.

Já a aluna A3, ao invés de traduzir a palavra car, utiliza-a antecedida pela preposição by, empregando a locução adverbial de modo e demonstrando o trajeto de sua construção de sentidos por meio do conhecimento dessa estrutura quando se fala sobre meios de transporte. Denota-se, deste uso, uma situação de aprendizagem escolar à qual a aluna pode ter se engajado. A professora, inclusive, menciona, diante da fala da aluna, que o tema de meios de transporte já havia sido estudado anteriormente:

\section{V: Até já estudamos essa palavrinha. Como é que você vai para a escola? A3: By CAR.}

Enquanto a professora chama de "palavrinha" a locução adverbial, acentuando o enfoque aos itens lexicais nas aulas de inglês, a apreensão da aluna contraria tal enfoque, clamando por um contexto, isto é, uma prática de letramento escolar em que se estudou o tema meios de transporte, o que desfaz o isolamento lexical e ultrapassa o momento em que a aula ocorre.

O mesmo parece ocorrer quando a aluna A1 diz já ter visto a palavra childhood em um brinquedo para crianças. Atentamos, novamente, para o fato de que o letramento escolar, tradicionalmente caracterizado pela linearidade, onde cabe perfeitamente a insistência em ensinar palavras descontextualizadas, é confrontado pelo letramento social do aluno, cujo cotidiano tem recebido cada vez mais inserções de língua inglesa, como podemos notar. Ressaltamos que a avaliação sobre as inserções da língua inglesa no cotidiano dos brasileiros 
e outros povos não falantes de inglês como primeira língua e as implicações dessas inserções figura como uma das expectativas de aprendizagem de língua estrangeira na modalidade EJA (SÃO PAULO, 2010), que se coaduna aos estudos dos novos letramentos.

Entretanto, essas inserções parecem apenas constar como uma forma de entender as palavras que a professora selecionou, sem que houvesse uma reflexão sobre o porquê de a aluna já conhecer algumas palavras, o que se configura como um exercício de letramento crítico. Conforme a defesa de Menezes de Souza (2011), é parte do exercício crítico o "ouvirse ouvindo", isto é, ter em conta as relações entre as interpretações do aprendiz e o contextosocial de que ele faz parte.

Mais uma vez, portanto, notamos que o conhecimento e o letramento social do aluno não são acionados de forma a se articularem ao letramento escolar aqui, mas serve como referência para atender ao propósito de responder às expectativas da escola, representada na prática da professora, testando os conhecimentos dos alunos (BARTON, ibid.).

Nesse trecho observamos, ainda, a limitação da atividade de língua inglesa ao léxico, o que se torna mais evidente se se compará-la à variedade de práticas envolvendo o tema do Dia das Crianças. Parece-nos que aos alunos não é dado o direito de uma imersão mais aprofundada, nem mesmo com atividades que realcem outros aspectos da língua.

\subsubsection{O trabalho com os alimentos, por Vívian.}

O excerto a seguir foi extraído do diário de campo produzido in loco e a posteriori e faz parte de uma aula ${ }^{35}$ em que dois temas foram abordados: Um olhar para dentro de mim e Saúde e Corpo Humano. Nessa aula, os alunos leram e discutiram uma fábula, estudaram as regras do verbo to be, estudaram nomes de frutas e planejaram-se para trazer frutas para uma atividade de pintura.

TRECHO 5
Nos minutos finais da aula, a professora retoma o vocabulário sobre frutas, já discutido no
começo da aula. Ela pede para que os alunos consultem as páginas 427-428 do livro didático.
Lê as frases da página, que acompanham ilustrações das frutas:
V: This is an apple, isto é uma maçã. Quem vai trazer apple?
A1: Eu.
V: A A1 vai trazer. That is a watermelon, aquilo é uma melancia. Quem é que vai trazer
watermelon?

\footnotetext{
${ }^{35}$ Outro trecho dessa mesma aula, em que se desenvolve uma exposição gramatical do verbo to be, também será discutido neste capítulo.
} 
A2: A A3, mas ela foi embora.

A4: Quem vai trazer a fruta que tem sete letras e termina com onze?

Vívian e alguns alunos comentam, tentando adivinhar qual é a fruta.

A4: O abacaxi.

Vívian demonstra estar impressionada com a esperteza da charada. Ela explica sobre os números romanos e elogia a aluna.

A5: Congratulations!

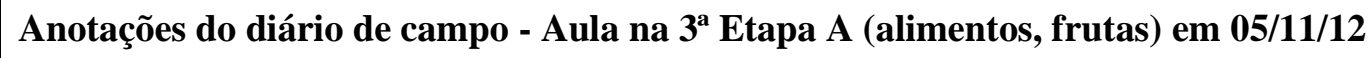

Apesar de ter envolvido uma série de atividades variadas para as outras áreas de conhecimento, como língua portuguesa e artes, a sequência não revela multiplicidade de atividades e abordagens com o inglês, limitada ao trabalho com o léxico.

Apoiada pelo material didático, a atividade de inglês disponibiliza ilustrações de frutas e sentenças indicativas, como This is an apple, mas, como não ocorreu um trabalho ou mesmo uma discussão específicos relacionados às imagens ou sentenças, o que por si configuraria, em certa medida, uma abordagem mais diversificada, entendemos que elas servem de instrumento ao objetivo de ensinar o léxico.

\section{6 A língua estrangeira pertence a alguém? A quem?}

Segundo os dados observados, o enfoque nos conhecimentos advindos do letramento escolar nas situações de aprendizagem descritas desdobra-se em um distanciamento entre os estudantes e o seu objeto de estudo, dificultando-lhes, ao mesmo tempo, o uso de seus conhecimentos prévios, construídos em práticas de letramento social, e a tentativa de empregar ferramentas e estratégias do letramento escolar, conforme discutiremos nesta seção.

Veremos, nesta seção, uma seleção de trechos de uma aula dedicada ao ensino das regras estruturantes do uso e da concepção subjacente ao verbo to be, em que se trabalhava com a leitura e a interpretação da versão em português para a fábula "O Alce e os Lobos", do escritor francês Jean de La Fontaine.

O texto, assim como as questões para o trabalho de interpretação, estava reproduzido no material didático, cuja proposta se seguia com algumas adaptações. Foram dispensadas pelo menos 3 (três) aulas para o mencionado trabalho ${ }^{36}$. Durante uma parte da correção de

\footnotetext{
${ }^{36}$ Menciono terem sido pelo menos 3 (aulas) dispensadas à leitura e interpretação da fábula porque as datas das minhas observações não coincidiram com a totalidade das aulas da professora Vívian com a referida turma. As
} 
questões de interpretação sobre a versão em português para a fábula, a professora conduz uma breve discussão que direciona os estudantes a questionar-se sobre as diferenças entre ser e de estar diante do mundo e, em especial, diante das adversidades da vida. Dessa breve discussão, a professora parte para a abordagem das flexões do verbo to be, traduzido para o português como "ser" ou "estar". A conexão entre o conteúdo reflexivo da fábula em português e o conteúdo gramatical flexões do verbo to be é realçada por parte da professora por meio da diferença lexical que existe entre as duas línguas. Ao reiterar que em português existem dois significantes distintos para os significados "ser" e "estar", a professora chama a atenção para as diferenças linguísticas, que podem modelar percepções de mundo, como expresso na ideia de ser e de estar. Isso é feito por meio da questão aos alunos sobre ser e estar serem coisas diferentes, ao que eles respondem que existem diferenças.

Apesar de estarem se dedicando há pelo menos 3 (três) aulas à leitura do texto, são apenas cerca de 15 (quinze) minutos dedicados à explanação da professora sobre o conteúdo específico de inglês, as regras gramaticais do verbo to be. Nesse curto período de tempo, a professora solicita que os alunos acompanhem a explicação por meio de tabelas com as formas afirmativa, interrogativa e negativa do verbo to be, reproduzidas no material didático. A aula é expositiva, dedicada à observação das regras acerca das formas do verbo to be afirmativo, negativo e interrogativo para todos os pronomes sujeito, embora a professora busque a todo o momento a participação dos alunos, por meio de perguntas, como se observa no trecho destacado abaixo:

\section{TRECHO 6}

V: Numa frase em inglês você tem que ver pelo contexto para saber se está dizendo ser ou estar. Só um exemplozinho, para vocês lembrarem. Se eu falo I am a teacher (escreve na lousa). Esse am é do verbo ser, do verbo to be em inglês. E se eu falar I am here (escreve na lousa), por exemplo, são diferentes, não é? Vamos ver qual seria a tradução? Se eu falo I am a teacher, vocês sabem que teacher é professora. Então seria que eu [pausado]...

A1: Eu amo.

A2: Eu sou.

Vários alunos: Eu sou professora.

V: Eu sou uma professora. Legal. Jóia!

$[\ldots]$

V: Agora, olha só. Se eu falar I am here. Here, pessoal, quer dizer aqui. Qual será que vai ser a tradução dessa frase? I sou eu. Eu sou aqui ou eu estou aqui?

A3: Eu estou aqui.

aulas dedicadas a essa atividade excederam o que foi previsto inicialmente porque, apesar da insistência da professora em que os estudantes realizassem os exercícios propostos pelo material didático em casa, para discussão e correção em aula, grande parte da turma não apresentava essas tarefas já feitas. Diante disso, Vívian reservou alguns minutos de cada aula para que os alunos realizassem as tarefas, oferecendo-lhes ajuda para tirar dúvidas. 
A4: Eu estou aqui.

V: Olha! É a mesma palavra, professora!

A5: Eu estou aqui.

V: Olha, aqui esse am é sou, não é? Eu sou uma professora. E o am nessa frase é eu estou aqui. Olha que interessante.

A1: É a mesma coisa.

$\mathrm{V}$ : O verbo ser, o verbo to be em inglês... a palavra am é do verbo to be, ela pode ser ser ou estar. Então, a gente tem que ver o contexto, o restante da frase para entender se é eu sou ou eu es-

A6: -tou.

V: E eles são iguais?

A7: Eu vou anotar isso no meu caderno.

Transcrição de trecho de aula $-3^{\text {a }}$ Etapa A (verbo to be) em 05/11/12

No trecho acima, a professora propõe como início de sua explicação a tradução do verbo em português. Notamos que a proposta é empregar os recursos já disponíveis para os alunos, isto é, seu conhecimento de língua materna. Entretanto, quando passa da palavra para as sentenças em que os alunos deveriam observar que só existe um único significante para pelo menos dois significados diferentes, o conhecimento de língua materna não é o bastante para auxiliá-los, como observamos na tentativa de A1 na tradução de I am como Eu amo. Embora a tradução da aluna esteja equivocada, entende-se que o erro tem referência na língua materna pela semelhança formal entre os verbos am, do inglês, e amo, do português. Outro ponto em que podemos observar que o conhecimento de língua materna não é utilizado como forma de auxiliar na construção de conhecimentos sobre a língua estrangeira surge quando a professora antecipa a tradução dos termos teacher e here, os quais são necessários para que os alunos compreendam as sentenças:

\section{TRECHO 6}

V: Se eu falo I am a teacher, vocês sabem que teacher é professora. Então seria que eu [pausado]... A1: Eu amo.

A2: Eu sou.

Vários alunos: Eu sou professora.

V: Eu sou uma professora. Legal. Jóia!

$[\ldots]$

V: Agora, olha só. Se eu falar I am here. Here, pessoal, quer dizer aqui. Qual será que vai ser a tradução dessa frase? I sou eu. Eu sou aqui ou eu estou aqui?

A3: Eu estou aqui.

A1: Eu estou aqui.

V: Olha! É a mesma palavra, professora!

Trecho da aula de 05/11/12 (Foco no verbo to be), aula com a $3^{\text {a }}$ Etapa A 
Após dois alunos traduzirem a frase corretamente, Vívian antecipa a conclusão da turma toda, isto é, anuncia que são duas frases cujo significado é diferente, mas que empregam o mesmo significante, o verbo $\mathrm{am}$. Como se pode verificar no vocativo empregado em sua antecipação, ela chega a simular a fala de um possível aluno que se dirige a ela própria. Nessa fala, não se chama a atenção dos alunos para a relação contexto-sentido das palavras, restando apenas o emprego da palavra por meio da própria palavra cuja significação reside com a professora.

\section{V: Olha! É a mesma palavra, professora!}

Embora Vívian já houvesse avisado desde o início dessa sequência que os verbos ser e estar são traduzidos como um só em inglês, conexão pela qual ela encerra a reflexão sobre as mudanças e as essências representadas na atividade anterior, trata-se de uma oportunidade para observação e dedução, presentes nas práticas de letramento escolar, que muito beneficiaria os alunos em suas estratégias de reconhecimento e aprendizagem de língua estrangeira no ensino formal. Ainda assim, a professora antecipa-se aos alunos e deixa escapar tal oportunidade de prática. A intervenção espontânea com a qual a aluna A1 traduz, no excerto, I am como Eu amo denota que a conclusão de que am significa "ser" ou "estar" não parecia tão clara para todos os estudantes.

Importante ressaltar que as duas frases empregadas para demonstrar as peculiaridades do verbo to be são selecionadas pela professora e destacadas de uma situação e/ou contexto que poderiam facilitar a compreensão dos alunos, mas acabam por distanciá-los de tal conteúdo. Isso é especialmente observável na primeira frase utilizada, I am a teacher, por dizer respeito à realidade da professora e não à dos alunos. $\mathrm{O}$ isolamento de aspectos linguísticos específicos para servir ao objetivo de demonstrar regras gramaticais, fonéticas ou lexicais, é uma estratégia bastante recorrente em ensino de língua estrangeira, conforme Ellis (2010). Embora compreenda que essa estratégia auxilie estudantes no desenvolvimento de uma metalinguagem facilitadora do entendimento sobre as regras e o uso delas em outras situações, o autor alerta para a limitação das práticas de ensino a ela, uma vez que ela é incompatível com princípios educacionais contemporâneos (ELLIS, 2010, p. 169), que visam a uma oferta de múltiplas abordagens e atividades que reflitam a multiplicidade da linguagem. Notamos essa preocupação com a variedade de abordagens e práticas pedagógicas, por parte da professora, no trecho abaixo, coletado de entrevista: 
Mas e a gramática? Ela é necessária? Sim, também. Tudo é necessário. O tradicional, o atual, o renovado, o construtivismo. Tudo é necessário. A gente tem que ter um pouquinho de tudo. É necessário ele escutar uma música, ele ver um filme, vivenciar um pouquinho essas situações e trabalhar com a gramática, sim. Por quê? A gramática também é uma questão de organização. Autonomia tanto no vocabulário quanto na gramática porque a gramática auxilia a gente a compreender melhor os termos, até a usar, saber como usar, dar uma base para o uso.

\section{Vívian, trecho de entrevista, grifos meus}

Conforme as próprias asserções da professora, o uso de frases isoladas não é um problema na sala de aula se fizer parte de uma multiplicidade de abordagens e práticas de ensino, que correspondam à heterogeneidade constitutiva das línguas, tais quais seus usuários e seus contextos. Não advogamos aqui a total erradicação desse tipo de exercício cujo propósito é aumentar a consciência sobre as regras da língua, mas apontamos para o maior significado dessa prática quando suplementar a outras atividades de aprendizagem que estejam de acordo com uma leitura mais ampla, da palavra para o mundo e vice-versa (FREIRE, 1982, 1997). Essa leitura de mundo ocorre via textos, ainda que graduados, produzidos para fins didáticos, pois é nos textos, orais ou escritos, que se materializa a linguagem.

Restringir-se a frases isoladas, que dão pouco sentido às práticas de letramentos dos alunos, sustenta uma prática que acaba por distanciar os educandos do acesso e da apropriação da linguagem como pertencente também a eles. Conforme a crítica de Reagan (ibid.), o isolamento de palavras e frases do contexto e dos falantes é uma prática oriunda de uma visão de linguagem predominantemente positivista, fundada na concepção de que existe uma realidade externa passível de entendimento e estudo científico empírico e que influenciou os estudos linguísticos por muito tempo. O problema com a visão positivista para o ensino de línguas, conforme pontua Reagan (ibid.) é que ela as reifica, considerando-as como sistemas objetivos, não-históricos, não-sociais, não-variáveis.

Em última instância, a reificação da língua resulta em um conflito de poder, ou seja, sobre quem tem o poder de determinar-lhe os padrões de correção e a quem ela pertence. No ensino e aprendizagem de língua em especifico, a reificação deixa subentendida a ideia de que a língua pertence tão somente à professora, isto é, à especialista a quem compete a tarefa de "transmitir", distribuir conhecimentos aos estudantes (CRAIG, 1995 apud REAGAN, ibid.), prática essa também denunciada por Freire $(1971,1982)$ por meio do conceito de "educação 
bancária”. O conceito de educação bancária remete ao pressuposto de educação que trata os educandos como vazios depositários dos educadores, que, por sua vez, na falta de expressividade dos educandos, vão fazendo suas "doações" de expressões para que os alunos sigam "capitalizando-as" (FREIRE, 1971). Esse tipo de prática acaba por impedir que o educando exercite sua expressividade, o que implica na ruptura do direito de perceber um sentido mais profundo na linguagem, e logo, da realidade que essa representa. Como consequência, pouco pode perceber-se na posição de interferir na realidade de forma transformadora (FREIRE, idem).

Vejamos o trecho a seguir, em que a professora mantém a estratégia de perguntas e respostas aos alunos para que esses entendam as regras gramaticais para a forma negativa do verbo to be.

\section{TRECHO 7}

V: Agora, olha lá no terceiro quadro, lá de baixo. Está escrito forma [pausando] nega...

Alunos: ...tiva!

V: O que aconteceu? O que apareceu de diferente? Vamos ver quem tira dez.

A1: Onde, professora?

V: Olha a A1 querendo tirar dez [risos]. Lá embaixo.

A1 Forma negativa, né?

V: Isso! Compara esse terceiro com o primeiro.

[vários alunos falam ao mesmo tempo]

A2: Tem mais letras, né.

$\mathrm{V}$ : Isso! Tem uma palavrinha a mais.

A3: Tem o not.

V: Qual a palavrinha... o not.

A4: Isso.

V: E essa palavra o not aparece para todas as pessoas? Para eu, para você, para eles, para nós? Todas as pessoas?

A5: Quase todas.

V: Então, olha se aparece em todas ou não.

A6: Não.

[Alunos falam ao mesmo tempo]

A1: De cima a baixo.

V: Olha, aparece de cima a baixo. Para todas as pessoas. O que será que é not?

A3: Notebook? [pronunciado nótibuk]

Transcrição de trecho de aula $-3^{\text {a }}$ Etapa A (verbo to be) em 05/11/12

Em sua abordagem, a professora cita uma prática típica do letramento escolar: uma situação de prova. Com isso, chama a atenção dos alunos para tentarem acertar as suas perguntas, imaginando-se em uma situação de avaliação. Diante das perguntas, alguns alunos, como A5, parecem tentar adivinhar as respostas corretas esperadas pela professora. As 
respostas incorretas, como a de A5, são descartadas pela professora, até que outro aluno dê a resposta esperada, como a resposta de A1. A confirmação da resposta por parte da professora é imediatamente seguida por outra pergunta ("Olha, aparece de cima a baixo. Para todas as pessoas. O que será que é not?”). A interação coincide com o modelo sugerido em pesquisas mencionadas por Barton (ibid.), onde se reitera que, embora a escolarização privilegie o texto escrito, muitas das atividades de sala de aula se centralizam na oralidade, isto é, tratam-se de falas em torno de textos escritos (talking around texts). Uma boa ilustração desse padrão, segundo Barton (ibid.), é a chamada regra dos dois terços, que presume que alguém fale durante dois terços do tempo dedicado à aula, sendo que esse alguém é o professor e sua fala se concentra basicamente em dar explicações e fazer perguntas.

No trecho em discussão, há pouco tempo para que os estudantes respondam ou mesmo reflitam sobre as perguntas, o que em geral levava a professora a dar as respostas para a turma, revelando-se uma prática de educação bancária (FREIRE 1971, 1982), isto é, o depósito de expressões dos educadores aos educandos.

Como anteriormente já vinha acontecendo, a aluna A3 arrisca uma resposta incorreta, porém relevadora das possibilidades (affordances), ou os recursos de que dispõe para construir sentidos. O erro na resposta, entretanto, não foi explorado ou mesmo considerado como subsídio para a garantia de maior sentido para a regra gramatical estudada.

O equívoco da aluna surge a partir de sua tentativa de compreensão acerca da pergunta da professora, notadamente uma pergunta que remete a uma abstração da linguagem ao demandar o significado de uma palavra sem o seu contexto. Sobre abstrações da linguagem, Gee (2013) critica a ênfase no pensamento abstrato nas práticas de letramento escolar, embora esse seja considerado uma sofisticação atribuída à escolarização, em detrimento de um ensino mais contextualizado e significativo nas escolas nos tempos atuais. Em seu argumento, Gee (2013) defende ser equivocada a visão de que a abstração exista por si só. De acordo com o autor, a contextualização é o princípio do pensamento abstrato, uma vez que esse não deixa de ter uma porção contextual em sua formação. Essas chamadas abstrações são produzidas em contextos específicos em que suas regras e postulações são colocados em prática, como se observou na fala de Vívian, no trecho 6, ao colocar os vocábulos junto de suas traduções para os alunos:

\section{V: Here, pessoal, quer dizer aqui. Qual será que vai ser a tradução dessa frase? I sou eu. Eu sou aqui ou eu estou aqui?}


Curioso notar que ao traduzir os termos isolados, Vívian institui a regra para a correta tradução do verbo to be, que ela está explicitando. Com essa estratégia, a tradução do verbo é feita corretamente pelos alunos, porém, sua compreensão sobre o funcionamento do verbo to be só nos parece adequar-se ao caso específico levantado pela professora, e não a outras situações. É por isso que os estudantes teriam maiores benefícios se pudessem, a partir da compreensão do funcionamento do verbo dentro de um determinado contexto, aplicar o que compreenderam a contextos outros, conforme propõem Kalantzis e Cope (2003, 2012, 2013) em sua proposta de pedagogia dos letramentos para o design de significados, ou, em uma versão mais recente de tal proposta, dentro dos processos de conhecimento. Refiro-me, quando menciono a importância de aplicação de uma aprendizagem a outros contextos, à quarta etapa desse processo, explicitado abaixo, de acordo com os autores:

(1) prática situada / experimentação (do conhecido, do novo)

(2) instrução explícita / conceituação (nomeando, com teoria)

(3) enquadramento crítico / análise (funcional, crítica)

(4) prática transformada / aplicação (apropriada, criativa) ${ }^{37}$

Retomando nossa análise do trecho 7, a aluna busca em seu repertório linguístico e em sua experiência algo com semelhança fonética e formal, também dissociado do contexto da aula. A aluna o faz com base no fato de que o significante notebook guarda semelhanças com not por causa da pronúncia de muitos falantes de português brasileiro, que imprimem a entonação de sua língua materna às palavras estrangeiras. $\mathrm{O}$ que também nos chama a atenção é o fato de que essa palavra tenha ocorrido à estudante é um indicativo de que uma importante ligação entre a língua inglesa e o cotidiano de brasileiros e falantes de diversas línguas ocorra por meio do léxico atribuído a equipamentos e recursos tecnológicos, notadamente os da área de informática, produzidos em países de língua inglesa, sobretudo os Estados Unidos.

Para ilustrar a problemática do tratamento dado ao ensino da regra gramatical situada apenas nos letramentos escolares, portanto descolada dos letramentos sociais dos alunos, reproduzimos a seguir o apelo de uma aluna durante essa aula:

\footnotetext{
${ }^{37}$ Do original, em Kalantizis e Cope (2013):

(1) situated practice / experiencing (the known, the new);

(2) overt instruction / conceptualizing (by naming, with theory);

(3) critical framing / analyzing (functionally, critically);

(4) transformed practice / applying (appropriately, creatively).
} 


\section{TRECHO 8}

V: Aí depois, a gente está vendo na interrogativa, lá no quadrinho lá da frente, que elas trocam de lugar, não é? Olha! Em vez de I am ficou Am I? Elas inverteram, olha. Em vez de I am ficou Am I. Todas são invertidas quando a gente quer perguntar alguma coisa. Eles invertem.

V: Mas calma, A.

\section{[A: Meu Deus do céu! Ai, professora...}

A1: Ai, meu Deus.

V: A A. ficou desesperada.

[risos]

V: É só perceber. O que está acontecendo aí? Olha uma pergunta de prova. Vamos ver se vocês pegam. Vai lá! O que está acontecendo na interrogativa? De I am virou Am I. O que aconteceu? A1: [?]

V: Mas o que aconteceu?

A1: Ele inverteu.

V: Ah! Olha lá! Já tirou dez na prova. [risos] Estão vendo? Ela já observou a diferença. Essas coisas é que são importantes.

\section{Transcrição de trecho de aula $-3^{\text {a }}$ Etapa A (verbo to be) em 05/11/12}

Aparentemente, no trecho indicado, diante da considerável quantidade de informações e estratégias de aprendizagem diferentes daquelas vivenciadas em seu cotidiano, a aluna A1 comunica à professora e aos colegas a sua frustração. Ainda assim, a professora se sustenta em uma prática de letramento escolar para auxiliar a aluna, pedindo-lhe que atente para a sua pergunta como se essa fosse uma pergunta de prova, um teste. Como recompensa pelo acerto na resposta, a professora simula ter dado a pontuação máxima dessa prova, o que nos leva a entender que é dada maior importância ao modelo autônomo letramento, que se articula independentemente das práticas de letramento social.

Vimos, nos trechos reproduzidos neste capítulo, as dificuldades para a oferta, nas comunidades observadas, de conteúdos mobilizados de modo significativo e integrado às experiências dos alunos, considerando-lhes os letramentos sociais em que se baseiam suas identidades. As práticas pedagógicas parecem se alinhar com uma visão autônoma de letramento, sob as quais o letramento escolar se desvincula das práticas sociais, presidido, basicamente, por lógicas próprias à escolarização, como as menções as situações de avaliação. Conforme já salientado anteriormente, o letramento autônomo não deixa de ser, também, ideológico, por posicionar os sujeitos em uma dinâmica social que se reflete no mundo fora do âmbito escolar. Em tais práticas, observa-se que os alunos pouco ou nunca precisam articular conhecimentos já construídos com aqueles mediados pela escola. Uma consequência desse distanciamento se visualiza nas dificuldades expressas pela aluna A1 no trecho 8 acima. Vívian, no momento mesmo em que procura acalmar a aluna quando essa reclama por não 
compreender o conteúdo exposto, usa outro instrumento das práticas de letramento escolar, as provas, inviabilizando, dessa forma, uma relação mais significativa entre A1 e o potencial conhecimento. 


\section{CAPÍTULO 3 \\ APROXIMAÇÕES ENTRE O LETRAMENTO SOCIAL \\ E O LETRAMENTO ESCOLAR}

\subsection{Introdução}

Neste capítulo, abordaremos as principais linhas teóricas que sustentam a visão de que os letramentos de mundo colaboram para o letramento escolar. Na sequência, descreveremos situações, coletadas a partir de nossas observações às comunidades escolares investigadas, em que predominaram as aproximações entre o letramento de mundo e o letramento escolar, para, finalmente, refletirmos sobre as implicações dessas aproximações para a formação desses indivíduos, à luz dos novos letramentos e das Orientações Curriculares para EJA.

\subsection{Textos e contextos: letramentos sociais e a cultura de massas}

Discorrendo sobre a importância desfrutada pela cultura e seu papel constitutivo em todos os aspectos da vida em sociedade a partir de meados do século XX, Hall (1997) destaca as mudanças e deslocamentos na cultura e pela cultura. Ou seja, de acordo com o autor, o cotidiano de uma parcela significativa da população se modifica em razão de demandas socioeconômicas advindas do declínio da indústria no século XX. Por outro lado, as próprias práticas e cotidianidades locais passam por mudanças advindas do sistema midiático que se quer global. Esse sistema traz para a rotina das pessoas mensagens e discursos que podem influenciar no sentido de mudanças de compreensão de mundo e construção de significados, inscritos na cultura. A partir da mundialização desse sistema midiático, evidencia-se o caráter híbrido da cultura, que passa a articular as localidades e as ditas globalidades - essas últimas também se tratam de localidades, porém ganham o status de globalidade como consequência de relações de poder que, inclusive, se atualizam por meio de sua difusão midiática

A partir da década de 1960, surgem estudos como os do autor canadense Marshall McLuhan ([1964] 2005), dedicados aos efeitos das tecnologias da comunicação e informação na construção de uma cultura global. É desse autor o termo "aldeia global", que designa a conexão entre as tecnologias, em específico a televisão e a representação de localidades ao redor do mundo, aproximando e estimulando as pessoas a construir uma cultura em comum, uma cultura global. 
Em função desse aspecto, Hall (1997) acredita serem raros os locais que não estão submetidos às forças culturais da mídia de massas, que provocam deslocamentos. Nesse sentido, o autor nos leva à seguinte reflexão:

\begin{abstract}
Pensemos na variedade de significados e mensagens sociais que permeiam os nossos universos mentais; tornou-se bastante acessível obter-se informação acerca de nossas imagens de - outros povos, outros mundos, outros modos de vida, diferentes dos nossos; a transformação do universo visual do meio urbano - tanto da cidade pós-colonial (Kingston, Bombaim, Kuala Lumpur) quanto da metrópole do ocidente - através da imagem veiculada pela mídia; o bombardeio dos aspectos mais rotineiros de nosso cotidiano por meio de mensagens, ordens, convites e seduções; a extensão das capacidades humanas, especialmente nas regiões desenvolvidas ou mais "ricas" do mundo, e as coisas práticas - comprar, olhar, gastar, poupar, escolher, socializar - realizadas à distância, "virtualmente", através das novas tecnologias culturais do estilo de vida soft. A expressão "centralidade da cultura" indica aqui a forma como a cultura penetra em cada recanto da vida social contemporânea, fazendo proliferar ambientes secundários, mediando tudo."
\end{abstract}

(HALL 1997, p. 5 )

Uma vez que cultura está inscrita e opera no interior do "jogo de poder", a educação é também uma instância da cultura, na medida em que se refere aos processos por meio dos quais a sociedade incute normas, padrões e valores, ou seja, a cultura, para que as gerações futuras ajam de acordo com os valores e normas compartilhadas pela geração de seus pais e pelo sistema de valores predominante. (HALL, 1997, p. 19).

É fato que o capitalismo industrial do século XX tende a suprimir subjetividades, embora por sua própria lógica, os produtos da indústria cultural estejam disponíveis visando a atender às demandas de um público que cumpre jornadas de trabalho longas e dispõe de poucas opções de lazer. Daí provavelmente deriva a popularidade da televisão (CASTELLS 2011).

Somando-se a isso, na segunda metade do século XX a configuração de uma sociedade em rede (CASTELLS, 2011), marcada pela convergência de várias transformações sociais, tecnológicas, econômicas e culturais importantes se ocorreu dando origem a uma nova forma de sociedade. Isto é, configura-se uma nova forma de ser no mundo.

Isso posto, o tema é oportuno a este trabalho por contribuir para a reflexão sobre a relação entre as práticas de letramento ocorridas fora do âmbito escolar, dentre eles, os artefatos da mídia e da multimídia, e os saberes valorizados e legitimados pela instituição escolar. Segundo Rocha e Maciel (2013), tal relação passa a ser questionada no âmbito educacional, centralizada na discussão a respeito de que tipo de conhecimento deveria ser valorizado nas práticas de escolarização. Entretanto, a partir dos anos 1960, o questionamento assume outro foco. A questão passa a ser "o conhecimento de quem vale mais". Com essa questão em voga, abre-se espaço para a apreensão das relações entre as políticas educacionais, 
o papel das tecnologias, a participação democrática, as disputas por poder, as noções de inclusão e exclusão, dentre outros (ROCHA e MACIEL, 2013), discussões tão caras ao contexto em que nossa pesquisa ocorre, a EJA.

Abordando a educação entre os setores populares, Setton (2004) aponta a premência de pesquisas que auxiliem na compreensão da complexidade do fenômeno da cultura de massa para a educação, como um bloco de cultura híbrido, marcado, ao mesmo tempo, pelas influências da cultura escolar e da cultura midiática. Segundo a pesquisadora (SETTON 2004, 2005), existe ainda muito preconceito, dentro e fora dos setores acadêmicos, a respeito da cultura midiática, reduzindo-a ao superficial e ao grotesco. Em seu argumento para desconstrui-lo, Setton (idem) pondera que o preconceito deriva de um elitismo herdeiro do modelo de educação iluminista que continua a nos formar, educação essa que assume uma função civilizatória engendrada por privilégios. A cultura escolar foi e ainda é uma marca de distinção social (BOURDIEU, 2011).

A respeito da cultura iluminista que priorizou saberes escolares e científicos em detrimento de saberes populares, Canagarajah (2002) elucida que trata-se de um desdobramento do projeto de modernidade, que posicionou a Europa, entre os séculos XVI e XIX, e os conhecimentos ali desenvolvidos, como referências para o mundo ocidental. A modernidade, como criticam Dussel (2012) e Grossfoguel (2012), respaldou-se em relações de colonialismo de terras e povos da América, culminando no apagamento e/ou marginalização de conhecimentos e culturas nessas regiões. Conforme a elucidação de Monte Mór (2013), o pensamento de colonialidade continua a orientar as práticas pedagógicas dos professores brasileiros, o que reacende o debate, iniciado nos anos 1960 com Paulo Freire, a respeito do desenvolvimento da criticidade e da agência como um dos objetivos do ensino de línguas (MONTE MÓR, 2013).

Ao discutir o letramento midiático (media literacy), Luke (1997) atribui ao posicionamento teórico pós-moderno a dissolução de noções eurocêntricas que distinguem alta cultura de baixa cultura, características de estudos sobre a cultura popular e a indústria cultural, empreendidos a partir dos anos 1930, como os de Max Horkheimer e Theodor Adorno, teóricos da Escola de Frankfurt. Assim, afirma a autora, os artefatos da cultura de massas e as práticas cotidianas de muita gente passam a ser levados a sério dentro da esfera acadêmica (LUKE, idem, p. 23). 
Para Luke (ibid.), o objetivo central do letramento midiático é tornar alunos audiência crítica e seletiva. Crítica das mensagens da TV, suas convenções, seus gêneros, características técnicas, demografia da audiência, e de seus próprios hábitos em face da TV (LUKE, ibid.).

Conforme já mencionado no Capítulo 1 deste trabalho, com Menezes de Souza (idem), a postura de criticidade em relação aos textos, midiáticos ou não, ganha um elemento importante que é genealogia, uma compreensão da própria leitura situada em seu contexto de produção. Dito de outra forma, a centralidade da prática de letramento crítico deixa de estar na produção do texto para valorizar-lhe a recepção, constituída sócio-historicamente e coletivamente, na comunidade a que se pertence e por meio das histórias que precederam a construção de significados (MENEZES DE SOUZA, ibid.).

Nesse aspecto, Giroux e Simon (1999) também são enfáticos ao asseverarem, sobre os bens simbólicos produzidos na cultura popular como tema de estudo e aplicação de pedagogia crítica:

(...) o estudo da cultura popular oferece a possibilidade de compreender como uma política de prazer serve para lidar com os alunos de uma maneira que molde, e às vezes garanta, as relações frequentemente contraditórias que eles têm com a educação e com a política da vida cotidiana. (GIROUX; SIMON, 1999, p. 214)

Uma vez que as mídias - digitais e analógicas - cumprem um papel importante para a formação e a informação de uma rede cultural de disputas pelo poder, questões de representação e identificação, subjetividades e uma determinada sociedade que se deseja fomentar, esse tema dialoga não apenas com o desenvolvimento de um trabalho pedagógico e crítico voltado para o contexto pesquisado, isto é, o universo da Educação de Jovens e Adultos. Reconhece-se, neste estudo, o seu esforço por oferecer uma prática educativa de qualidade e significativa às necessidades dos estudantes na sociedade que, ao mesmo tempo, compõem e são compostos. Antes disso, verifica-se a premência desse tema para os estudantes de uma forma geral. O acesso a informações, dispostas nos meios não escolares, como a mídia e a internet, ocorre de uma forma nunca antes percebida. 


\subsection{Do repertório popular para a sala de aula: a música como possibilidade de aprendizagem em contexto}

Elencamos, dentre os artefatos tecnológicos que adentraram o cotidiano dos estudantes e que se envolvem nas práticas sociais e de letramento, a audiência às estações de rádio e sua programação de músicas estrangeiras.

A associação entre música estrangeira e aprendizagem de língua inglesa é recorrente e sugere estudos a partir das mais variadas áreas do conhecimento, como em linguística aplicada, ensino de línguas, geopolítica, dentre outras. Abordando o tema a partir da perspectiva geopolítica, Giblin (2005) afirma que o rock'n roll, surgido nos anos 1950 nos Estados Unidos da mistura entre a country music, o blues e o jazz, é um dos principais propulsores da cultura pop no pós-guerra. Além dos artistas do rock, conforme esse autor, a construção de ícones do cinema hollywoodiano, como James Dean, reforçou, ao redor do mundo, a imagem dos Estados Unidos como um país onde se garantem ideais de liberdade e expressão.

Enquanto a Europa vivia o processo de reconstrução após as guerras, tal período de busca por novas identidades e experiências foi preenchido com a oferta daquela música de ruptura, jovem, rebelde, dançante e divertida, o rock. O autor afirma que o rock é originariamente violento, traduzido em letras críticas e irônicas, advindas principalmente dos artistas negros do blues e do jazz que o originaram.

Dos anos 1970 em diante, o rock passa de grito de contestação a um produto para consumo divertido, com exceção da rebeldia do movimento punk, surgido na Inglaterra em fins dos anos 1970.

Sobre a associação entre a cultura pop sob a vertente do rock e o desejo de seus apreciadores de entender suas letras, majoritariamente produzidas em inglês, Griblin (idem) conclui:

Quem hoje não conhece ao menos um refrão de uma das canções dos Beatles? Ao apresentar uma alternativa ao estilo de vida proposto depois da Segunda Guerra Mundial, o rock'n roll seduziu grande parte da juventude e contribuiu para impor o inglês como modo de comunicação internacional. (GRIBLIN 2005, p. 132)

A aprendizagem de língua inglesa tem, portanto, uma inegável relação de efeito da divulgação maciça de canções produzidas no contexto sócio histórico em que se insere a cultura de massas, divulgadas por dispositivos tecnológicos e culturais como o rádio, a televisão, o cinema e, mais recentemente, a internet. Entendemos que tais dispositivos que permitem o compartilhamento, cada vez mais expandido, de símbolos e discursos, estejam 
inseridos no letramento de mundo dos estudantes, o que merece especial atenção por parte de pesquisadores e educadores.

Vemos na abordagem com canções uma possibilidade pedagógica muito significativa por se tratarem de textos autênticos e, como tais, ofertarem um trabalho situado e relacionado ao cotidiano dos estudantes. A discussão de Fernandes (2008), a respeito do uso de canções no ensino de línguas, maternas ou estrangeiras, acentua a possibilidade de aprendizagem a respeito da cultura e do contexto sócio histórico que abrangem a produção musical em estudo, além do trabalho com os chamados temas transversais, ultrapassando, dessa forma, as limitações gramaticais e lexicais comumente priorizadas no ensino de línguas. Com canções, além da garantia dos elementos linguísticos articulados em textos completos, como a oralidade, as rimas, o léxico, os tempos verbais, dentre outros, é possível discutir o contexto que envolve a produção e a recepção da canção.

Conforme já mencionado na Introdução a esta pesquisa, meu interesse por músicas estrangeiras, durante a minha formação no ensino básico, me impulsionou a estudar inglês para compreender as letras das canções de que eu gostava. Em diversas ocasiões, eu pedia ajuda a colegas, que também estudavam inglês, para entender certos trechos.

A fala da professora Vívian, abaixo, sintetiza as concepções até agora abordadas, revelando que, entre muitos alunos, canções e outros textos da cultura midiática não são valorizados como objetos de aprendizagem. Antes, são tratados como atividades de lazer e entretenimento:

V: Nós, na sociedade temos o Inglês, por exemplo, nos filmes, nas músicas, em quase tudo. A dominação do Inglês, ela é muito forte, né. E é uma língua fácil, entre aspas, se comparar com outras, né, Japonês, né, que é bem mais distante da nossa língua. Mas mesmo assim, o pessoal não percebe o quanto consegue aprender. $\mathrm{O}$ jovem hoje em dia, não só hoje em dia porque na época da minha mãe também, tem muitos jovens que começam a gostar de uma banda Inglesa ou de um grupo ou de um cantor Inglês, eles começam a aproximar mais de Inglês.

P: Comigo foi assim [risos].

V: Minha mãe também. Ela começou a gostar de Beatles, ela traduzia todas as músicas dos Beatles, ela traduzia sozinha. Ia traduzindo mais ou menos assim, né, não tinha Internet. Hoje em dia a gente, com a rapidez que a Internet está, você pega a tradução na hora. Você não tem mais nem tanto trabalho. Talvez a gente possa até refletir sobre isso. Não tem mais tanto trabalho para ir atrás.

Vívian, trecho de entrevista 
Coincidentemente, na mesma semana, as duas professoras propuseram atividades com música, embora tenham seguido diferentes abordagens e objetivos. As canções foram alguns dos poucos textos autênticos utilizados durante o período de observações de aula ${ }^{38}$. Entendo por texto autêntico aquele que está na vida cotidiana, diferente do texto graduado, simplificado para fins didáticos. Tratamos primeiramente a atividade proposta por Milena e, sem seguida, a atividade de Vívian.

\subsection{Consciência negra, inglês e música}

Além de utilizar uma canção, entendemos que a atividade traça relações com a realidade dos estudantes e com seu letramento de mundo por explorar o tema do racismo, por ocasião da comemoração do Dia da Consciência Negra, ocorrido dois dias antes da aula em questão.

A canção selecionada é "Strange Fruit", composta por Abel Meeropol e interpretada por Billie Holiday em 1939 e detentora de forte teor de protesto, pois descreve o linchamento de um negro pendurado a uma árvore, o "fruto estranho" que intitula a canção. A canção se baseia em um poema de Meeropol, escrito em 1937 e inspirado na emblemática fotografia de Lawrence Beitler, de 1930, em que se veem os corpos de dois jovens negros linchados e pendurados a uma árvore, acusados de terem matado um homem branco e estuprado sua companheira $^{39}$. Frisamos que a história subjacente à canção é contada aos alunos durante a aula, depois de realizada a atividade. Um aluno, inclusive, diz querer conhecer outras canções de Billie Holiday e o faria utilizando a internet.

A aula é iniciada com a justificativa da professora, conforme se compreende do trecho abaixo:

\section{TRECHO 9}

M: O que é importante a gente pensar nesse dia?

C1: É o aniversário de...

M: Happy Birtyhday. Parabéns [...]. Pergunto para vocês pra gente pensar no dia da

\footnotetext{
${ }^{38}$ Além desse, a professora Vívian utilizou uma tabela nutricional em uma atividade sobre alimentos e suas propriedades nutritivas.

${ }^{39}$ Fonte: http://www.theguardian.com/music/2011/feb/16/protest-songs-billie-holiday-strange-fruit. Acesso em 19 de outubro de 2014.
} 
Consciência Negra e por quê ele existe. E a gente pensar aqui no nosso Brasil. No Brasil, existe preconceito, existe preconceito, existe racismo?

(Alunos falam ao mesmo tempo): Existe. Sim.

M: Muito, pouco ou mais ou menos?

Alunos: Muito.

M: Tá. E nos Estados Unidos? Vocês acham que tem racismo ou não?

Alunos: Tem.

M: Muito, pouco ou mais ou menos?

Alunos: Muito.

M: Muito? Se bobear, mais do que o Brasil até. Mas uma coisa que é complicado aqui, que é diferente de lá é que as pessoas, não só em relação ao racismo, ao preconceito de cor, mas as pessoas, em geral, no Brasil são mais discretas em relação aos preconceitos. Elas abafam, elas escondem os preconceitos. De repente, estou conversando com um amigo meu e "Ah, não, eu não tenho preconceito, mas..." Aí, a pessoa começa a falar e eu percebo quais são os mas. [...] Brasileiro é assim. Não estou falando que vocês são assim, estou falando mais em geral. Nos Estados Unidos, eles escancaram muito mais o que eles são, em relação a preconceito racial. Se acha que determinada etnia é inferior, eles deixam isso claro. Não sei o que é pior, uma pessoa que é preconceituosa e esconde, você não sabe quem é essa pessoa de verdade, ou uma pessoa que fala "porque eu acho que negro é isso mesmo". Os dois são terríveis, na minha opinião.

Transcrição de trecho de aula - $3^{\text {a }}$ Etapa A (canção Strange Fruit) em 22/11/12

Na sequência, toca-se a canção pela primeira vez com o objetivo, de acordo com a professora, de apenas ouvi-la para notar a melodia e o que essa poderia significar. Em seguida, a professora pergunta quais palavras vieram à mente ao ouvir aquela canção. Os alunos respondem com palavras como: sentimentos, tristeza, emoção e velório.

Com essas palavras compartilhadas pelos alunos, a professora passa a uma etapa de trabalho com a linguagem verbal da canção, explicitando que a melodia possui uma estreita relação com a letra da música, que é também triste e fúnebre. Dando sequência ao trabalho com linguagem verbal, Milena apresenta, na lousa, o seguinte conjunto de palavras, que os estudantes deveriam buscar reconhecer no momento em que ouvissem a canção:

\begin{tabular}{|lll|}
\hline THREE & FRUIT & EYES \\
GHETTO & SWEET & TREES \\
SALT & BLACK & RAIN \\
BITTER & BLOOD & SUN \\
SMELL & SOUTH & \\
\hline
\end{tabular}

Antes de tocar a canção pela segunda vez, faz-se uma leitura em coro da lista de palavras, garantindo-se a compreensão dos significados com a tradução das palavras, em 
alguns casos, e, em outros, com frases em língua portuguesa contendo a palavra em inglês, como em "Café sem açúcar é bitter" e em "Santa Catarina e Paraná ficam no south do Brasil”. Sem que tivessem sido solicitados, muitos alunos repetem as palavras, alguns repetem apenas as palavras em inglês, outros repetem a palavra em inglês e em português também. A professora aponta para as relações entre algumas dessas palavras, como sweet e bitter, palavras de carga semântica opostas.

Em uma das turmas, o $3^{\circ} \mathrm{B}$, logo após essa leitura das expressões, ocorre uma tentativa de relacionar as palavras articulando-as a uma narrativa antecipadora da letra da música da qual tais vocábulos foram extraídos. É o que se observa no trecho abaixo, de uma aluna:

\section{TRECHO 10}

M: Tem uma morte aqui, mas não é uma morte qualquer. A gente tem doce... Tenho, o que é rain mesmo? Chuva, tenho sun que é sol, tenho as trees que são as árvores. O que essas coisas têm em comum?

D1: É porque quando matou, aí estava sol, aí choveu.

Transcrição de trecho de aula - $3^{\text {a }}$ Etapa B (canção Strange Fruit) em 22/11/12

Nesse momento, os alunos são informados de que a próxima etapa da atividade será ouvir e completar a letra da canção em inglês. A seguir, eles recebem a letra da canção e são avisados de que a canção será pausada a cada estrofe, para facilitar. A professora explicita o que é estrofe e o que é verso e deixa claro que os alunos terão a oportunidade de ouvir a canção mais vezes, se necessário, não havendo motivo para preocupação caso não entendessem algum trecho. "O importante é o exercício", afirma Milena na ocasião.

Além disso, a professora convida os alunos a elaborarem uma narrativa a partir das palavras ofertadas, junto com seus significados. A estratégia de situar as palavras em uma narrativa favorece a aprendizagem, em especial em estudantes de EJA, uma vez que as narrativas constituem o principal estruturador da comunicação humana, conforme Bruner (2003). De acordo com o autor, a narrativa permite a participação em uma cultura e a transformação de experiências individuais em experiências coletivas, isto é, a construção de um fundo comum. Além disso, o uso de narrativas reforça o caráter relacional e contextual das aprendizagens.

Como se pode depreender a partir da descrição realizada até esse ponto, grande parte dessa atividade é dedicada ao trabalho linguístico de compreensão auditiva, apoiado em elementos narrativos, contextuais, melódicos e lexicais. Com essa variedade de elementos 
garantida pela abrangência do trabalho pedagógico, a atividade teve uma significativa proximidade do letramento social dos alunos, motivando-os a buscarem em seu repertório elementos que foram essenciais para sua participação e construção de conhecimentos.

Além disso, cumpriu-se efetivamente o objetivo, postulado no "Caderno de orientações didáticas para EJA Língua Estrangeira - Inglês” (SÃO PAULO, 2010), de levar os alunos à compreensão de língua como um fenômeno de múltiplas faces em operação, como as funções comunicativas, as estruturas gramaticais, o léxico, a construção de sentidos em um texto articulada ao contexto.

A atenção ao tema do racismo, partindo de uma data comemorativa presente no cotidiano $^{40}$, é também compreendida como uma medida pedagógica que esteve sensível ao letramento de mundo dos alunos, sem deixar de articular tal cotidianidade ao conhecimento e contexto histórico e a um posicionamento crítico. Dito de outra maneira, a indagação sobre o que se comemora no Dia da Consciência Negra, um fato que poderia ter passado irrefletido para uma parcela significativa da população, tal qual ocorre em relação a outros feriados, é a concretização de uma ação pedagógica que respeita a cotidianidade, mas deseja construir um posicionamento crítico, embasado em um conhecimento mais sistematizado e menos ingênuo sobre o mundo, conforme as lições de Paulo Freire.

Sabemos que a população negra é historicamente e economicamente marginalizada (FARIA; PAULA, 2008) e, não por coincidência, tende a apresentar índices mais altos de analfabetismo no Brasil ${ }^{41}$, se comparada à população de brancos. Daí, a importância da discussão a respeito do racismo e das condições das populações negras, no Brasil e no mundo, entre os alunos de EJA. Reflexo dessa relevância é o fato de que, ao longo da aula, diversos alunos tenham relatado episódios em que foram vítimas ou presenciaram racismo. Por outro lado, ao mesmo tempo em que a atividade promoveu o reconhecimento de si, por se tratarem de grupos com uma média de 20 a $50 \%$ de estudantes negros ${ }^{42}$, a atividade propiciou aos estudantes a reflexão sobre outras posições sociais, se considerarmos os alunos não negros e o fato de que todos foram convidados a pensarem-se no lugar de outrem, por se tratar de um texto que remete a práticas ocorridas nos Estados Unidos do início do século XX, e não em sua realidade imediata. Nesse sentido, a proposta cumpre com o objetivo, conforme descrito

\footnotetext{
${ }^{40} \mathrm{O}$ feriado municipal do Dia da Consciência Negra, dia 20 de novembro.

41 Conforme aponta, por exemplo, o documento de preparação para a mais recente CONFITEA, a VI Conferência Nacional de Educação de Adultos, com dados de 2006: 14\% entre a população negra e 6,5 \% entre a população branca, o que equivale a mais do que o dobro. Disponível em: http://portal.mec.gov.br/dmdocuments/confitea_docfinal.pdf Acesso em 5 julho de 2014.

42 Com base em fotografias tiradas durante as aulas.
} 
pelo Caderno de orientações didáticas para EJA Língua Estrangeira - Inglês (SÃO PAULO, 2010), de refletir sobre outros loci sociais.

Em grande parte da aula, é priorizado o trabalho com elementos linguísticos. Tal trabalho inicia-se com o vocabulário e segue com o convite ao reconhecimento dessas novas palavras na letra da música. Há uma prática de compreensão oral da canção, ou pelo menos, das palavras apontadas.

A discussão sobre o tema da canção ocorre em língua materna e configura-se como uma oportunidade para que os alunos comparassem, a partir de seu letramento de mundo, isto é, a partir dos discursos, leituras e símbolos inscritos em suas práticas sociais, o racismo no Brasil e nos Estados Unidos. Com essa proposta, os alunos são convidados a mobilizar aprendizagens e informações obtidas a partir de suas vivências, isto é, a discussão se baseou exclusivamente no letramento de mundo dos estudantes, notando-se que ela não envolveu o acesso a textos escolares (escritos ou não), informativos a respeito da questão em debate.

Os alunos concordam com a afirmação de Milena a respeito da incidência maior de racismo nos Estados Unidos, onde se acredita haver maior deflagração de preconceitos. Entre os estudantes também se concorda sobre a crença de que no Brasil o preconceito em geral ocorre de forma oculta. Além da vivência direta de situações em que o racismo é visível, entre os próprios estudantes ou seus familiares, amigos e conhecidos, pensamos terem sido recursos de referência, em especial quando consideramos o que se afirmou sobre os Estados Unidos, os dispositivos tecnológicos que possibilitam a expansão de textos de forma rápida e intensiva. Artefatos da cultura midiática, como filmes, canções, notícias de jornal e de telejornal, entre outros, podem ter sido a referência para realizar a proposta.

Finalizamos essa discussão com a fala da professora ao explicitar seus objetivos com essa atividade, em trecho de entrevista:

P: Como você viu a experiência da música "Strange Fruit"? Como você preparou, como você percebeu a devolutiva, qual era o seu objetivo?

M: Eu queria passar alguma música para eles.

P: Por quê?

M: Porque é diferente. Na última aula com a $3^{\mathrm{a}}$ etapa, em uma atividade de feedback final, teve uma senhora que pediu mais aulas com música. Eu queria trabalhar com música com eles, mas eu fico muito insegura porque eles são muito inseguros. Eu tenho medo de eles travarem, de eles ficarem com medo. Mas pensei, "vamos tentar, fazer uma coisa diferente". Tinha que ser alguma música lenta e que tivesse alguma relevância. Eu comentei com o pessoal, nossa equipe é muito boa, que eu adoraria passar essa música. Alguém falou "o dia da consciência negra está aí, você podia passar". Passei para $7^{\circ}$ e $8^{\circ}$ ano e EJA. Expliquei o que a gente ia fazer, mostrei 
as palavras.

P: Eles gostaram. Teve aluno que falou que ia procurar a letra da música na internet.

M: Eu gostei. A questão do listening foi difícil mesmo pra eles, de entender as palavras, claro, cada acerto foi valorizado. Expliquei, isso aqui não é prova, é a primeira vez que vocês fazem esse tipo de atividade. Então, eu não espero, como eu falo às vezes, não quero que ninguém saia falando fluente, nativo. É vocês saberem que existe, que faz parte do mundo de vocês e, claro, aprender o que puder ser absorvido. Maravilha. E foi a ideia da música também.

\section{Milena, trecho de entrevista}

\subsection{What a wonderful world}

Durante o período observado, Vívian utilizou duas canções do repertório popular em língua inglesa: "What a wonderful world” (1967), de Bob Thiele e George Weiss, popular pela interpretação de Louis Armstrong, e "You are my sunshine” (1939), escrita por Jimmie Davis e Charles Mitchell e gravada pela primeira vez em 1939.

Discutiremos, primeiramente, a atividade com a canção "What a wonderful world" e, na sequência, abordaremos a atividade com "You are my sunshine”.

A justificativa da atividade com "What a wonderful world", similarmente à de Milena, discutida anteriormente, centrou-se em um tema que se desenvolvia em outras atividades pedagógicas de todo o corpo docente. O tema, neste caso, era "Saúde e corpo humano", desdobrado sob os aspectos de alimentação e de recursos naturais, como se esclarece abaixo:

\section{TRECHO 11}

V: Vamos dar uma olhadinha na letra, porque a letra vai falar sobre um assunto muito importante que a gente vem falando muito, de alimentação e de natureza. $\mathrm{O}$ que vocês estão vendo no fundo da imagem [referindo-se à reprodução da letra da música no material didático, contendo uma imagem do planeta Terra]?

B1: O planeta.

V: O planeta Terra. Então, nesta música, vocês vão ouvir sobre o planeta Terra. Nesta música, vocês vão ouvir sobre o tema gerador desse ano, as relações humanas.

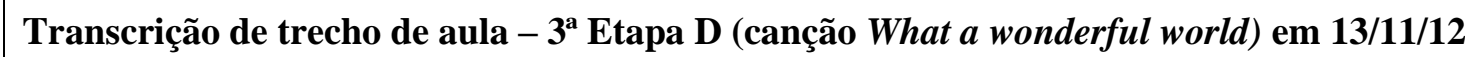


A canção "What a wonderful world", de 1967, surge em um momento de acentuada luta do Movimento dos Direitos Civis dos Negros, nos Estados Unidos, que mobilizou o país. De acordo com artigo da rede $\mathrm{BBC}^{43}$, o tom otimista e pacífico da canção encobre uma mensagem política, uma tentativa de apaziguar negros e brancos que protagonizavam tumultos violentos em mais de cem cidades dos Estados Unidos. Embora a canção contenha fortes motivações contextuais e políticas, Vívian não as explora na atividade, tratando apenas a mensagem de otimismo que se nota em sua superfície.

$\mathrm{Na}$ atividade, Vívian traz à sala de aula um violão. Ela explica que se trata de uma atividade com uma famosa música interpretada por Louis Armstrong, reproduzida no material didático e adaptada pela professora como um exercício de completar lacunas com palavras pré-selecionadas. Inicia com a justificativa, como já esclarecido acima, e com a observação da imagem apresentada no material. Em seguida, distribui a atividade de completar lacunas entre os alunos e ensina a pronúncia de cada palavra, ou grupo de palavras em cada verso, e pede para que os alunos as repitam. Ela discute o significado de alguns vocábulos e expressões mais longas, como vemos abaixo:

\section{TRECHO 12}

V: I see, see é do verbo ver. Eu vejo. O que eu vejo? I see trees. O que será que são trees? Na natureza, algumas são bem grandonas, às vezes são bem pequenininhas.

B1: Árvores.

$\mathrm{V}$ : As árvores, trees. E de que cor elas se vestem?

B2: Verde.

V: Green, verde. Olha que legal. Tem até o Greenpeace, que é uma entidade muito famosa, o Greenpeace. É a paz verde. Green, verde. Green é uma cor, um adjetivo. Uma qualidade, uma característica dessa árvore.

Transcrição de trecho de aula $-3^{\text {a }}$ Etapa $D$ (canção What a wonderful world) em 13/11/12

Após a discussão de cada estrofe, a professora retoma a tradução dos trechos para o português. Em seguida, ela toca a canção no violão e pede para que os alunos que quiserem a acompanhem. Sem parar de tocar, ela antecipa alguns trechos que virão e aponta em qual verso (ou linha) da canção ela está, para ajudar a turma. Os alunos respondem positivamente e, em geral, cantam junto.

\footnotetext{
${ }^{43}$ Disponível em http://www.bbc.co.uk/news/magazine-16118157. Acessado em 30 de outubro de 2014.
} 
Os dados da aula seguinte, obtidos pela descrição da professora, em vista da impossibilidade de eu estar presente, informam que os alunos foram levados ao laboratório de informática para assistirem na internet, pelo YouTube, a um vídeo da canção. Conforme esclarece Vívian na ocasião, o vídeo havia sido produzido por um internauta, e continha a letra da canção, acompanhada de imagens que visavam a ajudar na compreensão de seu sentido. De acordo com Vívian, nesse dia, os alunos saíram-se muito bem na tarefa de cantar a música, deixando de lado algumas inquietudes, que discutiremos no decorrer deste capítulo.

A atividade proposta por Vívian teve por objetivo relacionar o tema dos alimentos e da natureza a um texto autêntico e significativamente conhecido por uma parcela dos alunos. Um objetivo secundário, porém não menos importante, foi encorajar os alunos a cantarem a canção.

Embora não trate de aspectos situacionais da canção, como se sugere pelo fato de supostamente conter uma mensagem política produzida em um dado contexto sócio histórico nos Estados Unidos dos anos 1960, a utilização da canção como recurso pedagógico relacionou o tema estudado junto a essa e outras disciplinas escolares, a alimentação e a natureza. Com esse texto, os alunos puderam conhecer e reconhecer vocábulos e expressões em uso, abrangendo a oralidade de que músicas são construídas, em especial seus aspectos fonéticos e lexicais.

Como o material didático onde a letra da música está reproduzida não contém tradução ou glossário, nem foram fornecidos como complemento à atividade, a professora tratou de explicitar os significados da letra da canção por meio de um diálogo e de questões que buscaram acentuar os conhecimentos dos alunos. Notou-se que em alguns momentos a professora opta por não traduzir alguns termos, mas compartilha exemplos e definições de cada palavra em língua materna, o que auxilia os alunos em sua construção de sentidos a partir de suas compreensões e vivências de mundo, isto é, o repertório metalinguístico adquirido não apenas na instituição escolar, mas, principalmente, fora dela. Tratou-se, portanto, de reconhecer e valorizar o que os estudantes trazem de suas vidas para a escola.

A contemplação da multimodalidade para auxiliar a compreensão do texto, conforme se observa no uso de um instrumento musical e no uso do vídeo postado por um internauta no YouTube, ampliou as possibilidades de construção de sentidos desse texto.

Durante a atividade, a professora estimula os alunos a cantarem a canção, o que implica em um reposicionamento. Alguns alunos, antes mesmo de tentarem, comentaram ser difícil cantar e aprender inglês. Uma aluna diz não ser possível aprender inglês na escola, com 
práticas de letramento escolar, mas apenas "na convivência", ou, como aqui realçamos, nas práticas de letramento de mundo. O comentário da aluna está reproduzido abaixo:

\section{TRECHO 13}

B1: Desse jeito, a gente não aprende, não. A gente aprende com convivência, falando.

V: Também. Se aprende de várias formas.

B2: O que a gente aprende aqui, só aqui, a gente vai pra casa e aí, só semana que vem. A gente esquece tudo.

V: Pode pegar na internet essa música. "What a wonderful world".

[vários alunos falam ao mesmo tempo]

B2: A maioria das pessoas não sabe nem Português direito.

V: Será que o Inglês não ajuda a falar melhor o Português também?

[vários alunos falam ao mesmo tempo]

B3: Sempre tem música em Inglês na rádio.

Transcrição de trecho de aula - $3^{\text {a }}$ Etapa D (canção What a wonderful world) em 13/11/12

Ressalto a distinção entre as variadas formas de aprender, tão evidentes entre alunos de EJA. A aluna B1 critica as práticas de aprendizagem via letramento escolar, que se restringe ao espaço e ao tempo da escola, pouco se relacionando com as práticas cotidianas, já que só ocorrem "uma vez por semana". A professora, entretanto, ressalta uma prática de letramento de mundo para que essa aprendizagem esteja mais próxima da cotidianidade, facilitando a aprendizagem: ler a letra da canção em um website da internet. Junto com a defesa feita pela professora está a fala de B3, que lembra ao grupo outra prática de letramento de mundo: as estações de rádio brasileiras veiculam músicas em inglês, sendo possível, portanto, praticar o idioma cotidianamente, ouvindo canções.

Percebo duas reflexões a partir desse trecho.

Em primeiro lugar, é ainda forte a percepção, entre os alunos, de que o letramento de mundo e o letramento escolar não podem se articular.

Ao mesmo tempo, B1 valoriza o letramento de mundo, via aprendizagens informais por convivência com pessoas que falem o inglês. Dentre as situações que forneceriam as condições para tal, a fim de se compreender a qual convivência B1 se refere, está a experiência de viver em um país de língua inglesa. Observamos nela um efeito do mito do falante nativo (KUMARAVADIVELU 2012; RAJAGOPALAN 2003), legitimando apenas os 
conhecimentos e experiências de aprendizagem centralizados nos países de língua inglesa e, consequentemente, marginalizando os eventos de aprendizagem e letramento ocorridos em outras circunstâncias. $\mathrm{Na}$ esteira do mito do falante nativo ainda há o forte apelo mercadológico em torno dos intercâmbios, como se sugere pela afirmação de que não há outras maneiras de se aprender.

Por outro lado, B1 pode ainda estar se referindo à convivência com outros falantes de inglês em comunidades de aprendizagem, onde cabe a própria escola, desde que ela tivesse outra dinâmica.

Diante de tais revelações a respeito do desafio quanto às limitações e resistências demonstradas por parte de alguns alunos, percebemos que essas ocorreram em decorrência do estímulo a deixar a posição de recepção ${ }^{44}$ da língua para a adoção de uma postura de ação, de não apenas escutar, mas de efetivamente tentar (ainda que erroneamente) cantar a canção. A mudança de atitude e posicionamento implica em uma superação de medos e preconceitos advindos da suposta ideia de incapacidade que se instala nesses aprendizes em relações de poder que envolvem o domínio não apenas de línguas estrangeiras, mas também de variedades prestigiadas da língua materna falada e escrita, representadas pela instituição escolar, segundo o esclarecimento de Faria e Paula (ibid.) e como se pode depreender a partir da fala da aluna B2:

\section{B2: A maioria das pessoas não sabe nem Português direito.}

A resistência dos estudantes para cantarem a canção e as fala de B1 e B2 podem ser entendidas pelo viés das relações de poder que subjazem o ensino de língua estrangeira, conforme pontuam os estudos de linguística crítica, que se apoia nas teorias pós-coloniais, pós-estruturalistas e pós-modernas. Para Rajagopalan (2003) e Kumaravadivelu (2012), estudiosos de linguística crítica, a história do ensino de língua inglesa como língua estrangeira ao redor do mundo se centralizou no mito do falante nativo e em seu aliado, o mito da competência de falante nativo, referindo-se aos falantes nascidos em países anglófonos. Segundo Kumaravadivelu (2012), o falante nativo, no decorrer das práticas de ensino de inglês como língua estrangeria em países pós-coloniais, tem sido recorrentemente reverenciado como o modelo de correção e adequação expressiva, o que ocasiona a busca

\footnotetext{
${ }^{44}$ Embora se entenda que a recepção de bens simbólicos não seja um ato estritamente passivo, pois demanda a interpretação desses signos, em si, uma ação inscrita em um contexto que é referido no ato mesmo de construir significados, conforme elucidação de Ricoeur (1972).
} 
idealizada, por parte dos falantes não-nativos, de aproximarem suas competências comunicativas às dos falantes não-nativos. Como consequência, a expressão e os conhecimentos dos falantes não nativos são deslegitimados e desvalorizados. $\mathrm{O}$ autor assevera que o mito do falante nativo sustenta uma dependência epistêmica entre professores e alunos de inglês como língua estrangeira, resultando na marginalização de falantes não-nativos e, consequentemente, acentuando relações neocoloniais (KUMARAVADIVELU, idem, p. 5). Segundo Rajagopalan (2003), esse processo também tem como produto a diminuição da autoestima de aprendizes, que acreditam que a língua estrangeira e sua respectiva cultura são superiores às suas (RAJAGOPALAN, idem, p. 68).

Ressalto, na fala da aluna B2, sobre os alunos não falarem Português direito uma compreensão, herdada, de que é necessário primeiro dominar a norma culta da língua materna para, só então, aprender uma língua estrangeira. Reflete a ideia de 'estado-nação', defesa da língua materna como um dos símbolos de estado-nação, de patriotismo.

No contexto de EJA, é sabido que a marginalização ocorre primordialmente em relação à cultura escolar como um todo, porém se acentua na aula de inglês, como pudemos observar nos trecho acima citados. Embora muitos alunos reproduzam o discurso de empregabilidade ampliada com o domínio da língua estrangeira, que se sustenta em ideologias neoliberais, há sinalizações de que não pensam ser algo que lhes é devido. Por isso, a resistência em cantar a canção, ou em dizer que jamais aprenderão a língua. Ora, pensamos aqui, junto com Rajagopalan (ibid.), que aprender é esse de que os alunos falam. Se aprender for sinônimo de falar como um nativo, de fato, o mito do falante nativo segue seu caminho desencorajando a apropriação da língua inglesa.

\subsection{O A-ha moment do aluno J.}

Embora a professora não tenha apontado para posicionamentos críticos durante a atividade, entendemos ser importante ressaltar a criticidade em razão da colaboração do aluno J., entrevistado logo após a atividade com a canção. Em entrevista semiestruturada, em que eu buscava recolher informações sobre o perfil desse aluno, sua trajetória e suas acepções sobre as aprendizagens que vinha desenvolvendo, o aluno comenta ter reconhecido na letra da música um ensinamento de vida muito útil. Chamaremos esse momento de aprendizagem, 
proporcionado acidentalmente pela atividade com a canção, de Aha moment, como em Morgan (2012), para descrever um tipo de epifania, deliberadamente colocada ou não, em que algo - um texto, uma fotografia, uma discussão em sala de aula, por exemplo - esclarece e reaviva algo que nos pareceu vago ou menos relevante no passado.

Para entendermos como ocorre essa intepretação do estudante, que aproxima a prática pedagógica ao seu letramento de mundo, buscamos apoio em Morgan (2012), que defende o ensino crítico de língua inglesa como língua estrangeira, em abordagem crítica de ensino e aprendizagem de língua voltada para o desenvolvimento de independência epistêmica e de agência entre professores e estudantes contemplando teorias do conhecimento construtivistas, ecológicas e pós-estruturalistas. Com essas teorias contempladas nas práticas pedagógicas, Morgan (2012) afirma ser possível construir as condições e possibilidades para que ocorra a consciência e a agência, que estão no centro de uma abordagem crítica de ensino e aprendizagem de línguas. É nesse sentido que Morgan (2012) enfatiza não ser possível que professores desenvolvam a agência e capacidade transformadora entre os alunos, da forma como ocorre, por exemplo, no aprendizado de gramática. É daí que se acentua que o que se pode fazer, nesse sentido, é criar as condições sob as quais estudantes comecem a tomar a iniciativa crítica em relação ao seu aprendizado e ao seu contexto (CLARK 2003 p. 175 apud MORGAN, 2012, p. 44).

Um ponto chave sobre quais seriam essas condições é a compreensão de que a consciência crítica e a agência são fenômenos emergentes, isto é, elas advém da situação pedagógica em que estão inseridas. Consequentemente, é importante consolidar práticas pedagógicas centradas em teorias do conhecimento e aprendizagem como o construtivismo, a ecologia de saberes e o pós-estruturalismo. Assim, entende-se a linguagem e a aprendizagem como práticas sociais, interativas e que ocorrem situadas em um contexto sócio-histórico construído dialogicamente.

Retomando o trecho mencionado, contextualizo que na referida entrevista eu havia perguntado a J. quais eram os seus objetivos em relação aos estudos. Com isso, J. começou uma reflexão sobre os esforços necessários para terminar o Ensino Fundamental e seu desejo de fazer um curso superior. É nesse ponto de sua reflexão que se dá o comentário transcrito abaixo:

Colocar as coisas nos mínimos detalhes, tranquilo, só com esforço próprio... Tem um pedacinho da letra da música que ela fala assim, quando eu pensar comigo mesmo [trecho "And I think to myself, what a wonderful world", da canção "What a wonderful 
world" interpretada por Louis Armstrong, que a prof. Vivian apresentara na aula daquele dia]. Agora eu só penso comigo mesmo. Eu estou conversando com você aqui mas eu nem com a minha família eu converso.

\section{- J. em entrevista concedida dia 13/11/12}

Vemos que J. atribui um significado pessoal para a letra da música trabalhada por sua professora na aula de que ele tinha acabado de participar. $\mathrm{Na}$ aula, a professora trouxe a letra de "What a wonderful world", junto de sua tradução. Embora não parecesse ser o objetivo específico da professora de J. provocar consciência crítica e agência sobre esforços individuais ao trabalhar com essa música, J. interpretou o conteúdo linguístico nessa atividade de acordo com uma reflexão sobre suas atitudes individuais. Para J., "think to myself" significa pensar consigo mesmo no sentido de pensar por si próprio em oposição a esperar pelo pensamento dos outros. Ao pensar por si próprio, J. tem a expectativa de buscar e alcançar seus objetivos sozinho, sem contar com o apoio nem mesmo de sua família, como revela no final do trecho. Com essa interpretação, no momento da entrevista, J. pôde relacionar a expressão apresentada em sala de aula com ideias que ele supostamente já tinha construído sobre seus esforços individuais. É nesse sentido que vemos que um momento consciência crítica e agência, um "Ah-há moment, não como algo deliberadamente previsível ou alcançável tal qual uma meta/um papel do professor que empodera seus alunos para a promoção de justiça social. Contudo, esse momento emerge da situação, que é possível a partir da construção de condições para isso, como vemos no momento em que o aluno se apropria do conteúdo linguístico para nomear sua situação de vida e suas ideias sobre ela com relação aos estudos. As condições podem ter sido, além do conteúdo escolhido pela professora, a discussão ocorrida no final da aula, a minha pergunta sobre seus objetivos, o que, juntos, acabou por esclarecer algo para J. Por um lado, a interpretação de J. sugere um momento de agência, por pensar-se responsável pelas próprias ações no jogo de poder. Por outro, vemos em sua fala um traço de reprodução de uma lógica meritocrática, que apaga as desigualdades do jogo social ao centralizar exclusivamente no indivíduo, não no sistema, os louros e os fracassos de sua atuação. 


\subsection{You are my sunshine: familiaridade e confiança}

A atividade com a canção "You are my Sunshine”, a princípio, ocorreria somente entre os estudantes do $1^{\circ}$ módulo, com quem Vívian estava trabalhando à época das observações. Entretanto, durante a atividade com What a wonderful world, diante da dificuldade de alguns alunos em cantar a canção, ocorre o comentário da professora de que essa seria uma canção cuja letra é mais simples, o que poderia facilitar uma possível atividade. A professora explica que essa foi a canção escolhida para uma apresentação dos estudantes do $1^{\circ}$ módulo no dia da entrega do material didático naquele ano. De acordo com Vívian, como aqueles estudantes, que estão na escola há menos tempo, se saíram muito bem na atividade, a turma em questão conseguiria se sair melhor ainda, já que estavam no $3^{\circ}$ módulo.

Assim, nos minutos finais de uma aula mais dedicada aos estudos de língua portuguesa, Vivian traz propõe a atividade com a canção. Ela tece comentários sobre a popularidade e a variedade de versões conhecidas da canção. Explica que a canção é de domínio público, como as cantigas de roda. Os alunos recebem a letra da música, com lacunas a serem completadas. Há seis opções de palavras, fora de ordem, que completarão a música:

\section{MY ME ARE LOVE GRAY NEVER}

A seguir, Vívian comenta cada palavra e discute seu significado, como ocorre no trecho abaixo:

\section{TRECHO 14}

V: E a última palavrinha? Never...

Alunos: Never

V: Tem até uma música do... It's now or never. De quem é?

B1: Do Elvis.

B2: Elvis Presley.

V: Elvis...

Als: Presley.

$\mathrm{V}$ : Ele pegava o microfone assim [imitando o cantor].

[risos]

V: It's now or never é agora ou nunca. It's now or never.

Transcrição de trecho de aula $-3^{\text {a }}$ Etapa D (canção What a wonderful world) em 04/12/12 
Tendo repassado as palavras e garantido a compreensão de seus significados, Vívian pede aos alunos que repitam-nas para verificar a pronúncia. A seguir, ela faz uma breve tradução da letra da música, lembrando a performance dos alunos do $1^{\circ}$ módulo. $\mathrm{Na}$ sequência, Vívian canta a canção, repetindo-a por quatro vezes, variando o ritmo, enquanto os alunos completam as lacunas da letra. Nesse momento, é possível notar que alguns alunos cantarolam alguns trechos da canção junto com a professora.

Durante a correção, os alunos respondem com notável confiança. Inclusive, Vívian volta a cantar os trechos que contém lacunas, deixando que os alunos completem, praticamente em coro e no ritmo da canção, as palavras que faltavam. Ao final da correção, um aluno diz ter acertado todas as palavras.

Vemos que a principal motivação para essa atividade é oportunizar o aumento de confiança dos estudantes em relação à aprendizagem da língua, mostrando-lhes que eles são capazes de realizar a tarefa proposta. De acordo com Brown (2010), facilitar o desenvolvimento da autoestima dos aprendizes, as inserções de confidence boosters (injetores de confiança), como lembrou Milena, figura nos princípios que norteiam as práticas contemporâneas de ensino de língua estrangeira. Para o autor (BROWN, idem), o sucesso obtido pelos aprendizes em uma tarefa é parcialmente influenciado por sua crença de que são capazes de realizá-la.

Ainda que o objetivo de aumentar a confiança dos alunos em relação ao uso da língua, trazendo para a sala de aula um texto inserido nos letramentos sociais dos estudantes, qual seja, a prática da apreciação de uma canção do repertório popular, observa-se, mais uma vez, a ênfase no léxico, conforme pontuamos no Capítulo 2.Trata-se de uma prática que revela uma visão tradicional de ensino de línguas, deslocada do contexto e focalizada no sistema, abordado fragmentariamente em expressões e vocábulos que, consequentemente, perdem o sentido. É um efeito da tradicional e tecnicista visão de língua pela língua, que apaga das práticas das salas de aula seu elemento contextual e problematizador.

\subsection{A cultura midiática em She-Ra e He-man}

Em trecho já explorado no Capítulo 2, em que Vívian explica aos estudantes sobre as formas do verbo to be, Vívian articula elementos advindos de letramentos sociais para auxiliar o desenvolvimento do letramento escolar. Refere-se a dois desenhos animados da televisão, 
aparentemente populares, para aproximar os alunos do conteúdo estudado, como se observa no trecho abaixo:

\section{TRECHO 15}

A1: Eu vou anotar isso no meu caderno.

V: Isso! Vocês têm no livro, também. Lá na parte de inglês. Vocês têm no livrinho. Dá uma olhadinha. Aproveita. Lá na página 400... 400, é. Só que deixa marcadinha a 34 e 35 para não mexer nela. Mas dá uma espiada na página 400. Quatro zero zero... Four hundred. Em inglês, se fala four hundred [enquanto alguns alunos repetem a expressão four hundred]... Olha só que interessante [circula pela sala verificando se os alunos encontraram a página]. É o verbo to be. Lembra dele, que nós aprendemos? A gente usa muito [o verbo to be para], perguntar quem é você, quem sou eu, quem somos nós, o que fazemos, o que somos, onde estamos. Where are you from, lembra? De onde você é. A forma afirmativa seria eu sou, você é, ele é... Está vendo aí no primeiro quadrinho? Fala comigo uma vez, eu sou, I am.

[Depois de localizado o quadro, Vívian lê cada pronome e verbo da tabela, em português e em inglês. Ela solicita que os alunos repitam.]

V: Agora, she é ela. Lembram da She-Ra [cantando], do He-Man [cantando]? Vocês assistiram o desenho da She-Ra e do He-Man?

[Alguns alunos comentam que não]

A2: Já.

V: É meio antigo, mas alguns já viram a reprise. Então, she é ela e he é ele. He is... ele é, ou ele está. E she é ela, she is, ela é ou ela está.

Transcrição de trecho de aula $-3^{\text {a }}$ Etapa A (verbo to be) em 13/11/12

Tendo se certificado de que os alunos acompanhavam as instruções com a página correta aberta, inclusive utilizando a oportunidade, tal qual sempre fazia nas aulas como um todo $^{45}$, para dar uma instrução sobre o número da página inglês, Vívian segue para a leitura da tabela do verbo to be em sua forma afirmativa, auxiliando os alunos na tradução de todos os pronomes-sujeito. Nota-se, aqui, uma tentativa de lembrar os alunos acerca de um vocábulo com o qual eles podem estar familiarizados por causa de personagens dos desenhos animados norte-americanos She-Ra: The Princess Power (She-Ra: A Princesa do Poder) e He-Man and the Masters of the Universe (He-Man e os Mestres do Universo) ${ }^{46}$, produzidos nos anos 1980 e exibidos no Brasil por uma grande emissora de TV até meados da década de 1990.

A referência da professora aos desenhos animados, parte da cultura midiática, se aproxima muito das práticas de letramentos que entendemos serem importantes no engajamento dos educandos com a língua estrangeira, embora Luke (1997) aponte que She-

\footnotetext{
${ }^{45}$ Em diversas oportunidades a professora utilizava o inglês em suas falas, mesmo em aulas não dedicadas especificamente ao inglês. Uma forte recorrência dessas inserções ocorria em seus elogios ao desempenho dos alunos (Congratulations! Very good! Excellent!), sendo que alguns alunos também empregavam esses elogios entre si, durante as aulas.

${ }^{46}$ Embora a exibição do desenho tenha se encerrado na TV aberta do Brasil, o personagem He-Man permanece nas práticas de letramento na era digital por meio da fan page brasileira Conselhos do He-Man, destinada a aconselhar internautas, em especial os adolescentes, em seus dramas cotidianos.
} 
Ra, He-Man e outros desenhos animados surgem no contexto do estímulo ao consumo por parte das crianças, com a venda de brinquedos de seus personagens.

Ainda assim, a referência leva em conta as práticas de letramento social a que os alunos têm acesso. No caso em questão, a professora aponta para um elemento do letramento social, o título de um programa de televisão para explicitar um conceito do letramento escolar, qual seja, os pronomes he e she. Notamos, junto com os trabalhos de Lange (2010) e Prado (2011), nos quais as pesquisadoras desenvolveram sequências didáticas de inglês para alunos de duas turmas de EJA em Porto Alegre, que o desenvolvimento de uma metalinguagem que facilite a aprendizagem de línguas se fortalece quando, contrariando a típica abstração do letramento escolar, parte de um elemento contextual e, portanto, dotado de significado (cf. PRADO, idem, p. 130).

\subsection{Reconhecendo e discutindo estrangeirismos no contexto brasileiro}

Embora durante as aulas não tenham ocorrido reflexões ou discussões formais sobre emprego de palavras da língua inglesa no cotidiano dos brasileiros, o que inclusive figura como um dos objetivos do ensino de língua estrangeira na EJA, conforme acentuado pelo Caderno de orientações didáticas para EJA Língua Estrangeira - Inglês (SÃO PAULO, 2010), considerei importante trazer o tema para este capítulo por ter registrado, nas diversas aulas observadas, expressões e vocábulos em inglês empregados pelos estudantes ou pelas professoras, compreendidos pelos alunos.

A primeira percepção é a de que tais registros dialogam com a hipótese por mim elaborada, antes do início desta pesquisa: se o repertório de aprendizagens, construído tacitamente ao longo da vida, é importante para as aulas na EJA, e, se o inglês está, de diversas maneiras, adentrando a cotidianidade de uma parcela cada vez mais significativa de brasileiros, são também valorizados os conhecimentos de língua inglesa desses estudantes durante as aulas. Entretanto, no avançar da pesquisa, notei que tal hipótese contraria um suposto consenso, recolhido dos depoimentos das duas professoras colaboradoras, e que está presente entre outros professores, de que os alunos de EJA não conhecem, não possuem repertório de inglês. É o que se depreende dos trechos de entrevistas às duas professoras, reproduzidos abaixo:

V: Quando eu vim trabalhar aqui, eu lembro que eu estranhei demais porque para eles as aulas eram de 
Português e as próprias professoras só davam aula praticamente de Português. Inglês era no geral, assim, uma cultura da escola. A necessidade da alfabetização era tão grande, mesmo a quinta série, que priorizava-se a língua materna. Então sabe o que se ensinava de Inglês por ano, o ano todo quando eu entrei aqui? Números, cores, dependendo do módulo, profissões... Era lista de palavras. Está entendendo? Eu lembro que ficava o bimestre inteirinho, a única coisa que era trabalhada era partes do corpo, mas sem ligação com nada.

P: Sem ter uma coisa que se prolongasse.

V: Sem ter uma referência também de onde a gente pode encontrar isso na vida prática real, de onde eu posso usar isso. Então não tinha nenhuma conexão com a realidade. Eu lembro que eu fui trazendo algumas ideias. O pessoal era muito, muito fechado, minhas colegas que ainda estão aqui trabalhando comigo hoje em dia, aí depois de mim entraram dois professores que tinham uma visão mais aberta. E aí, algumas das nossas amigas que já estavam aqui também ampliaram a visão delas. Começaram a falar, "É verdade, a gente pode dar...". “Ah, mas eles não vão saber”. Tipo, eles não sabem nem ler e escrever em Português direito. Olha só, os professores. Isso é fala de professor. Que estão aqui ainda. Não estou criticando, estou falando que é uma visão.

P: Uma visão que está difundida, né.

V: Que está difundida e foi difundida em tantos anos de escola que a gente vê aqui. Então, por exemplo, eles não sabem nem ler e escrever. A gente dá o basiquinho, só uma visão. What's your name, números e cores, isso já está ótimo para eles.

Vívian, trecho de entrevista

M: Bom, é o seguinte, eu não tenho grandes pretensões com inglês na EJA. Não que eles não sejam capazes, mas eles vêm, por mais que eles tenham escolaridade, eles têm uma certa defasagem. Eu sempre faço planejamento pensando na minha sala, e naturalmente esse planejamento vai mudando ao longo do ano, porque eu vou vendo até onde eu consigo ir, qual é o limite dos meus alunos, o que dá para fazer o que não dá. Às vezes, eles me surpreendem, o que é muito bom, aí eu vou adiante. Eu aproveito tudo o que eu recebo deles, todo o retorno que eles me dão. Então para mim EJA é sempre lucro, porque normalmente eles estão muito dispostos a aprender. Por mais que normalmente eles tenham receio, eles sabem que eles precisam aprender, eles escolheram estar aqui. Na maioria, esse é o caso, eles escolheram estar aqui. Do mesmo modo que o inglês, eu procuro dar uma base, e procuro mostrar para eles como o inglês é importante no mundo, e como muitas vezes faz parte da vida deles e eles não sabem.

Milena, trecho de entrevista

Confrontado aos exemplos de conhecimentos de inglês, expostos nas aulas observadas, o suposto desconhecimento dos alunos, apontado pelas professoras, não se refere a um desconhecimento per se, mas advém de uma cobrança tal por um conhecimento sistemático, desenvolvido justamente por meio da escolarização, que acaba por obscurecer os conhecimentos próprios dos alunos, ingênuos ou não, ideologicamente marcados ou não, 
desconsiderando-os. Efetivamente, os exemplos de estrangeirismos trazidos pelos alunos não conduzem a reflexões, nem são ponto de partida para outros trabalhos durante as aulas.

Pontuo que a sistematização, que inclusive passa pela tomada de consciência a respeito do fenômeno em que palavras do inglês - e de línguas estrangeiras, de modo geral - passam a figurar no léxico de outras línguas, não é um elemento pronto, dado, que está no mundo, mas a ela subjaz uma prática pedagógica, dentro da escola e que corresponde a seu importante papel de propor reflexões sobre a própria língua e sobre a língua de outros contextos, comunidades, posições sociais e culturas (SÃO PAULO, 2010). Essa reflexão, inclusive, ocorre por meio do desenvolvimento de uma metalinguagem, pertencente à escola, dentro de seus processos.

Listo-os e discuto-os nesse capítulo articulando-os a uma proposta de trabalho pedagógico que empregue esses saberes como ponto de partida para o desenvolvimento de novos saberes, situados e críticos.

a) Cupcakes: No $3^{\circ} \mathrm{A}$, da professora Vívian, durante a revisão sobre alimentos (nutritious and junk food) a aluna V. lembra que em festas são servidos cupcakes. Pequeno bolo, preparado para servir uma única pessoa, que se popularizou nos Estados Unidos ${ }^{47}$. O nome é uma referência à xícara, medida e recipiente empregado na preparação da receita. Nos anos 2000 essa receita passou a figurar na culinária e em algumas festas brasileiras, como festas de aniversário, especialmente as infantis.

b) Notebook: A pesquisa demonstrou que alguns alunos, nas duas escolas colaboradoras, compraram o equipamento por causa da escola, para realizarem pesquisas em casa. Além disso, durante aula já mencionada neste trabalho, questionada por Vívian sobre o significado da palavra "not", uma aluna responde que "not" significa "notebook".

c) Energy drink: Durante apresentação de vocabulário de Milena, um aluno repete a palavra drink e acrescenta energy drink. Relativo à publicidade e, portanto, ao consumo, o conhecimento do termo energy dirnk, por parte do aluno, nos leva a refletir sobre a invasão de produtos importados nas práticas sociais do Brasil.

\footnotetext{
${ }^{47}$ Fonte: http://pt.wikipedia.org/wiki/Cupcake. Acesso em 19 de outubro de 2014.
} 
d) Seven up: Enquanto Milena trabalha com a canção "Strange Fruit", um aluno lhe pergunta por que as palavras seven up são escritas separadamente, mas pronunciadas como se fossem apenas uma.

e) Big: $\mathrm{Na}$ explicação sobre adjetivos opostos, Vívian cita uma rede brasileira de supermercados com esse nome, que esteve presente na região onde a escola se localiza até $2005^{48}$, quando foi comprada por uma multinacional do ramo.

f) Greenpeace: Quando Vívian explica cores, menciona a organização não governamental, fundada em 1972, por ter em seu nome a cor verde, para se referir à natureza.

g) News: Ao explicar aos alunos a palavra newspaper, Milena cita dois canais de televisão brasileiros, disponíveis em planos por assinatura, perguntando aos alunos do que esses canais tratam. Os alunos respondem que eles apresentam notícias.

h) Frost free: Em aula sobre as fontes de energia, Milena lista, junto com os estudantes, aparelhos domésticos que funcionam à base de energia elétrica. Durante a discussão, um aluno menciona as geladeiras frost free, cujo descongelamento é automático.

i) Kiss: Durante aula de Milena sobre as partes do corpo e do rosto, dentre eles, boca (mouth), logo após um estudante perguntar à professora como se dizia "beijo" em inglês, uma estudante comenta que existe uma marca de chocolate chamada kiss.

j) Toy: Na aula comemorativa do Dia das Crianças, Vívian pergunta aos alunos o que quer dizer Toy. Uma aluna responde que "Toy é brinquedo, referente ao filme".

k) Childhood: Na mesma aula mencionada acima, uma aluna diz já ter visto a palavra childhood em brinquedos para crianças.

O levantamento acima nos informa que o repertório linguístico em inglês referido espontaneamente durante as aulas foi construído nos letramentos sociais dos estudantes, inseridos em um contexto de consumo que carece de uma abordagem crítica quanto ao status

\footnotetext{
${ }^{48}$ Fonte: http://www1.folha.uol.com.br/folha/dinheiro/ult91u97083.shtml Acesso 15 de novembro de 2014.
} 
do inglês como uma commodity. Uma variedade de vocábulos da língua inglesa adentra o cotidiano brasileiro e, sem dúvidas, em outros países, via relações de consumo. Basicamente, todas as palavras se referem a práticas de consumo, de geladeiras a chocolates, passando por nomes de bebidas, empresas e organizações internacionais.

A ilustração mais acentuada e, portanto, que pode servir ao propósito de sintetizar tal tendência, está colocada quanto ao contexto do vocábulo kiss. A professora estava ensinando, conforme discutido no Capítulo 2, um conjunto de palavras e expressões para nomear partes do corpo, aparentemente sem contexto. Um aluno passa a modificar essa abstração de forma relacional, associando a palavra mouth, que a professora acabara de ensinar, à palavra beijo e pede a tradução dessa palavra. A professora fornece a palavra, kiss, e, imediatamente, uma aluna o associa a uma marca de chocolates. Portanto, a aluna conhecia o vocábulo enquanto uma marca de chocolates, mas ainda não conhecia seu significado em outros contextos. Essa é uma percepção que nos demanda atenção, já que revela a necessidade de um papel importante das aulas de língua inglesa, especialmente em tempos de globalização, que é conhecer e posicionar-se criticamente ante as relações de poder figuradas nos usos e nas interações entre as línguas.

Como se pode depreender do comentário de Vívian, reproduzido abaixo, estar incluído em contexto que levanta uma variedade de palavras e expressões do inglês sem, no entanto, conhecê-las ou mesmo refletir sobre suas implicações é uma realidade não apenas entre os alunos de EJA, mas entre muitos alunos:

V: Exato! Eu dei um ditado. Eu falei hot dog no ditado... "Professora, hot dog não é Inglês!"

P: [risos]

V: Juro! Oitava série no Estado. Outros, até não quiseram falar, né, são menos bocudinhos, fizeram assim (expressão de dúvida) e não sabiam escrever hot dog. Eu dei ditado, fiz uma lista de todas as palavrinhas usadas no Brasil, sabe, e a gente trabalhou bastante esse ano na oitava série, porque é uma oitava série bem fraquinha... E o pior é que eu falei, isso daí a gente nunca trabalha na escola, mas tem que trabalhar sempre. Começar do que a gente usa, porque aí vai fazer um gancho maior, né. Dar texto, ué, como é que a gente consegue entender um texto que a gente nunca viu lá milhares de palavras? Através dos cognatos e através dessas palavrinhas conhecidas nossas. Não é assim? Você vê palavrinhas usadas no Brasil, você vai fazendo ganchos e às vezes você descobre outras, né, que a gente não sabe... E aí a criançada começou a perceber, falar "Nossa, professora, é mesmo, né. Quando eu escrevo, vai, 'Eu comi um hot dog no shopping e comprei um - sei lá, uma lingerie - ah, lingerie é do Francês - uma top, uma baby look, um short, uma jeans, pronto. Você está falando e escrevendo Inglês e nem sabe.

Vívian, trecho de entrevista 
Acentuamos até agora que a articulação entre os letramentos sociais e os letramentos escolares corresponde a visões e práticas pedagógicas que respeitam e valorizam os saberes populares, incluindo os saberes construídos via a mediação da cultura midiática, que costuma ter um forte apelo entre os meios menos escolarizados.

Entretanto, ressalta-se que os conhecimentos do letramento social trazem o contexto de consumo, geralmente associado ao inglês, o que exige abordagens críticas no ensino de línguas para que a sistematização dos conhecimentos no contexto escolar favoreça também o avançar das reflexões a respeito das relações de poder entre línguas e culturas, para que se garantam as condições a uma participação social mais democrática e autônoma (MACIEL e ROCHA, 2013; MONTE MÓR, 2013; FREIRE, 2011). 


\section{CONSIDERAÇÕES FINAIS}

Todo ponto de vista é a vista de um ponto (BOFF, idem)

No Capítulo 1 desta pesquisa, sob o título "Bases teóricas para o ensino de inglês na EJA por meio dos novos letramentos", abordamos as principais questões sócio históricas que justificam o surgimento dos estudos de letramentos (novos letramentos, multiletramentos e letramento crítico) em meados da década de 1990. Dentre essas questões, destacamos os efeitos das globalização e das tecnologias digitais, que modificaram os parâmetros do jogo social, desde a comunicação, as relações socioeconômicas, passando, consequentemente, pelas formas de construção de sentidos. Confrontando os estudos tecnicistas de leitura e alfabetização, os estudos iniciais de letramento inspirados pelos trabalhos de Paulo Freire na década de 1970 sofreram uma revisão para abarcar as novas demandas. Se novas formas de se construir sentido passaram a operar, novas formas de se aprender língua e, portanto, novas formas de se ensinar língua foram contempladas. Essa relação pedagógica é agora problematizada em função das relações de poder, da situação sócio histórica em que ocorre, de forma a dar novos sentidos para uma ação transformadora na sociedade, criando as condições para uma ação mais democrática de agenciamento e construção de futuros sociais, conforme defendem Cope e Kalantizis (ibid.). Ainda no esteio dos estudos de letramentos, Menezes de Souza (ibid.) atribui, dentre os propósitos de criticidade que eles abarcam, a função de aprendizagem sobre as diferenças a partir da busca pela compreensão genealógica da própria leitura de textos e de mundo.

Finalizamos o Capítulo 1 recortando as principais visões pedagógicas, filosóficas e políticas no histórico da EJA no Brasil, pontuando a sua relação com desigualdades estruturais do país. Compreendemos que essa pesquisa dialoga com a falta de trabalhos em EJA que se estendam para além da etapa de alfabetização, por situar-se em suas etapas finais do que ensino fundamental, em que a disciplina de inglês surge como uma área de estudos específica. Colaborando para essa visão que vai além da alfabetização, concordamos, com Fávero (2009), que a ação em EJA deva esforçar-se por uma visão mais abrangente da escolarização e dos conhecimentos. Abordamos, ainda, os mais recentes avanços no que tange às funções da EJA, que são três, de acordo com o Parecer CNE/CEB 11/2000: função reparadora, função equalizadora e função qualificadora. Subjacente à última função, está o conceito de educação ao longo da vida (life long learning), isto é, a compreensão de uma educação que entenda que os sujeitos estão em formação por todos os períodos de suas vidas, expandindo-se o estudo e a 
construção de conhecimentos como processos que nunca terminam. O conceito tem sido criticado por pesquisadores, por considerarem-no uma resposta ingênua às demandas do capitalismo veloz e global, que necessita de trabalhadores e consumidores ágeis e aptos para mudanças sem questionarem as situações de desigualdade que tal sistema socioeconômico possa ocasionar. Enfatizamos, portanto, a necessidade do letramento crítico para compreender as nossas visões e práticas pedagógicas, retomando-lhe um de seus principais precursores, Paulo Freire que, a meu ver não por acaso, realizou seu trabalho sob os efeitos de sua experiência na EJA.

No Capítulo 2, intitulado "Distanciamentos entre o letramento social", abordamos as diferenciações e intersecções entre o letramento escolar e o letramento social, discutimos concepções de conhecimento, língua, educação e letramento trazidos pelas orientações didáticas oficiais a respeito das expectativas de aprendizagem de inglês como língua estrangeira na EJA. Ante tal discussão, analisamos momentos coletados de nossas observações em que notamos que o diálogo entre os dois tipos de letramento ocorre de forma problemática. Destacamos, aqui, a defesa de Freire $(1982,1997,2005)$ ao diálogo entre os saberes de educadores e educandos, porém sem perder de vista a importância da sistematização do conhecimento de forma a alcançar uma visão menos ingênua do mundo.

Nos distanciamentos entre os letramentos sociais e escolares, notamos traços do letramento autônomo, que trata as práticas escolares desvinculadas às práticas sociais. Aqui, notamos entre as professoras, por meio de uma dinâmica de perguntas e respostas, já observada por Barton (ibid.) uma exigência de conhecimentos metalinguísticos específicos às práticas escolares que ainda não tinham sido construídos.

Em contraposição ao distanciamento entre os letramentos escolares e sociais tratados no capítulo acima mencionado, o Capítulo 3, "Aproximações entre o letramento social e o letramento escolar", tratou dos momentos mais frutíferos coletados das observações. Por compreendemos que os letramentos sociais contemplados nas aulas muitas vezes se associaram à cultura midiática, buscamos apontamentos sobre as relações entre tal cultura e as aprendizagens escolares. Salientamos, entretanto, que os momentos frutíferos de articulação entre os letramentos sociais e os letramentos escolares não deixou de merecer nossa atenção, por terem, muitas vezes, referenciando relações de consumo sobre as letramento crítico pode atuar de modo a fornecer os subsídios para uma participação mais democrática e transformadora por parte dos estudantes na sociedade. 
Recuperando a epígrafe utilizada no primeiro capítulo e nas considerações finais aqui apresentadas, em uma pesquisa qualitativa de cunho etnográfico, enfatizamos o caráter interpretativo e situado de toda enunciação. Busquei compreender, dentro das limitações do meu lócus, as relações pedagógicas em ação nas comunidades observadas, presenciando momentos frutíferos de aprendizagens compartilhadas por alunos e as professoras colaboradoras. Respeitando os pressupostos teóricos mobilizados para a reflexão realizada ao longo do trabalho, não poderia deixar de mencionar o meu próprio processo de construção de sentidos e de conhecimentos: neste momento de finalização da pesquisa, certifico-me de que não esteja imprimindo um tom conclusivo a essas considerações, mas, antes disso, um apontamento a respeito das questões orientadoras e que podem servir de insumos para novos diálogos e novas pesquisas.

Retomamos a primeira pergunta norteadora, apresentada na Introdução deste trabalho:

1. Os conhecimentos construídos em práticas escolares se relacionam com os conhecimentos construídos ao longo da trajetória dos estudantes? Em caso positivo, como essa relação é visualizada nas aulas? Em caso negativo, que leitura é possível fazer dessa desconexão?

A pergunta pressupõe a articulação entre o letramento escolar e o letramento social, tendo como objetivo reunir e interpretar dados que corroborassem ou refutassem tal relação e suas respectivas implicações. Os dados foram apresentados e discutidos ao longo dos Capítulos 2 e 3, nos quais se observaram momentos que chamamos de distanciamento, no Capítulo 2, e distanciamentos, no Capítulo 3. Dentre os distanciamentos, notamos a excessiva ênfase no tratamento lexical por parte de ambas as professoras colaboradoras como prática de letramento escolar. Notamos que mesmo no trabalho com temas, que a princípio obedece à visão conhecimento integrado entre as disciplinas escolares e a realidade dos estudantes, utilizando uma gama variada de linguagens e conhecimentos para compreender aspectos das trajetórias e do mundo que cerca os estudantes, o trabalho de língua inglesa se verifica como um estudo isolado de palavras. O trabalho lexical é acentuado em traduções, realizadas pelas professoras, de termos que soam como equivalências absolutas, desconectando-se do contexto e de suas implicações. Além disso, a metalinguagem, necessária aos estudos específicos de gramática, é construída de forma expositiva e descontextualizada, com traduções de termos que só fazem sentido no âmbito das frases utilizadas como exemplo para a aplicação de regras. Os alunos por vezes estiveram limitados a testemunhar a professora, uma especialista, fazendo a aplicação das regras de forma isolada, com pouco tempo para deduzir ou refletir sobre tais regras de forma mais significativa, aliada à própria realidade. 
Interpretamos, com os distanciamos, que algumas das práticas pedagógicas aqui selecionadas acabaram por enfatizar que somente as professoras, enquanto especialistas, é que detêm o conhecimento da língua, o que implica uma possiblidade reduzida de expressão e, consequentemente, de ação social e transformadora por parte dos alunos.

Já no Capítulo 3, coletamos amostras de aproximação entre os letramentos escolar e o social, o que não foi sinônimo de práticas mais harmoniosas. Os dados revelaram a interferência da cultura midiática durante as aulas, sob a qual muitos conhecimentos importantes são desenvolvidos. Vimos como amostras da cultura midiática a utilização de canções do repertório popular que foram trazidas para a sala de aula com objetivos diversos: discutir o tema do racismo, cantar uma canção que tratasse de um tema condizente com o projeto da escola, oportunizar momentos de autoconfiança em relação à língua estrangeira. Ainda assim, conflitos estiveram presentes, como a ausência do contexto em duas das canções trabalhadas e a ênfase, já mencionada no Capítulo 2, no léxico.

Ainda no Capítulo 3, tratamos sobre o que chamamos, com Morgan (2012), de um " $A$ há moment", um momento de epifania trazido por um aluno entrevistado, a partir de uma canção trabalhada por sua professora. Nesse momento epifânico, entretanto, notamos que o aluno reproduz um discurso meritocrático e reprodutivista, o que nos faz repensar o papel do letramento crítico, especialmente entre os estudantes de EJA. Corroborando essa preocupação, trouxemos amostras de palavras e expressões recolhidas de falas espontâneas dos alunos durante as aulas, em seus processos de construção de sentidos, que sinalizam a presença da língua inglesa em relações de consumo sem um trabalho mais crítico e sistematizado quanto a esse tema.

Reproduzimos a pergunta 2 norteadora dessa pesquisa:

2. Que entendimento têm professoras e estudantes de EJA sobre a relação entre as práticas de letramento escolar e as práticas de letramento social?

No contexto observado, percebemos uma relação conflituosa acerca da articulação entre os letramentos sociais e escolares, traduzida em discursos, reflexivos sobre as práticas pedagógicas, que não se materializam no dia a dia da sala de aula. Ilustrando tal conflito, extraímos de uma entrevista com Vívian, a concepção de que "o texto é o que está na vida" enquanto os textos trabalhados em sala de aula foram tratados de forma escolarizada, focalizando o léxico. Com Milena, entendemos uma preocupação em tratar de temas delicados como o racismo, com uma canção trabalhada sob aspectos enfatizadamente lexicais, também. 
Em entrevista, ainda, a professora destaca os elementos metodológicos, situados especificamente nas práticas escolares, como a de listening (compreensão oral) e as dificuldades de tal exercício, sem, no entanto, mencionar os conhecimentos de mundo dos alunos. Além disso, discussão gerada em torno do tema do racismo, embora tenha sido acolhedora, não visou à prática da expressividade dos alunos em inglês.

Com relação a Vívian especificamente, temos a informação de que participou da formação continuada de professores oferecida pela SME em 2010, essa, por sua vez, orientada pelos insumos dos novos letramentos. Contudo, a professora não demonstrou ter articulado os abordados conceitos dos letramentos, que valorizam a contextualização e a localidade de conhecimentos adequada à realidade e às necessidades dos estudantes, trazendo, ao invés disso, sequências didáticas tematizadas, como o tema do Dia das Crianças, focalizadas em listas de vocabulário.

Esse conflito não passa despercebido pelos estudantes, que reproduzem angústias, como pudemos notar em falas de estudantes que problematizavam as práticas escolares, desde a criação de um feito cômico a respeito da repetição de um vocábulo isolado até a resistência direta à disciplina de língua inglesa na escola, com a afirmação de que só se aprende inglês com a convivência.

Vemos, portanto, a necessidade de reformulação das práticas pedagógicas levando em conta as alternativas subsidiadas pelos estudos de letramentos, extremamente úteis ao contexto de EJA, por respeitar as localidades das práticas sociais dos estudantes. Acentuamos, além disso, a premência do letramento crítico para uma melhor oportunidade de reflexão sobre as posições sociais ocupadas pelos estudantes e como elas se relacionam com questões de desigualdade de poder na sociedade que se deseja construir, contribuindo, assim, para um importante passo para sua participação democrática e transformadora de futuros sociais.

Almejamos, com essa pesquisa, contribuir para a fomentação do debate acerca de tais alternativas, no âmbito do ensino de línguas, entre educadores, pesquisadores e todos aqueles que queiram uma sociedade mais justa, construída por sujeitos críticos e atuantes nesse sentido. 


\section{REFERÊNCIAS}

BAKER, C. D.; LUKE, A. (Eds.).Towards a Critical Sociology of Reading Pedagogy. Philadelphia: John Benjamins Publishing Company, 1991.

BAKHTIN, M. Discourse in the Novel. In: RICE; P. WAUGH, P. (Eds.) Modern Literary Theory: a reader. London: Edward Arnold, 1989.

BAKHTIN. M.; VOLOCHÍNOV, V.N. Marxismo e Filosofia da Linguagem: Problemas fundamentais no Método Sociológico na Ciência da Linguagem. São Paulo: Ed. Hucitec, 1997.

BAUMAN, Z. Globalização: as consequências humanas. Rio de Janeiro: Jorge Zahar, 1999.

BIESTA, G. From Critique to Deconstruction: Derrida as a critical philosopher; Education after Deconstruction: Between Event and Invention. In: PETERS, M. \& BIESTA, G. Derrida, Deconstruction and the Politics of Pedagogy. New York: Peter Lang, 2009.

BHABHA, H. K. O local da cultura. Belo Horizonte: Editora UFMG, 1998.

BOFF, L. A águia a galinha: a metáfora da condição humana. Petrópolis: Vozes, 1997.

BOUCHARD, P. Human Capital and the Knowledge Economy. In: FENWICH, T.; NESBIT, T.; SPENCER, B. (eds.) Contexts of Adult Education: Canadian Perspectives. Toronto: Thompson Educational Publishing, 2006.

BOURDIEU, P. Espaço Social e Espaço Simbólico. In: Razões Práticas. Campinas: Papirus, 1996. A economia das trocas linguísticas. São Paulo: EDUSP, 1998.

A economia das trocas simbólicas. São Paulo: Perspectiva: 2011.

BRITTO, L. P. L. O ensino da leitura e da escrita numa perspectiva transdisciplinar. In: BAGnO, M. (et al.), CORREIA, D.A. (org.) Práticas de letramento no ensino: leitura, escrita e discurso. São Paulo: Parábola Editorial; Ponta Grossa, PR: UEPG, 2007.

BRASIL, Conselho Nacional de Educação. Parecer CNE/CEB 11/2000. Diretrizes Curriculares Nacionais da Educação de Jovens e Adultos. Brasília, 2000. 
BRASIL, Ministério da Educação. Nota técnica - Índice de Desenvolvimento da Educação Básica. Disponível em

$<$ http://download.inep.gov.br/educacao_basica/portal_ideb/o_que_e_o_ideb/Nota_Tecnica_n1 _concepcaoIDEB.pdf> Acesso em 01 maio 2013.

BRASIL, Ministério da Educação. Diretrizes Curriculares Nacionais Gerais da Educação Básica Brasília: MEC, SEB, DICEI, 2013.

. Ministério da Educação. Lei de Diretrizes e Bases da Educação Nacional. Brasília: MEC, 1996. Disponível em: 〈http://portal.mec.gov.br/arquivos/pdf/ldb.pdf> Acesso 27 julho 2014.

BRUNER, J. A Interpretação Narrativa da Realidade. In: A Cultura da Educação. Porto Alegre: Artmed, 2001.

Acts of Meaning. Cambridge: Harvard University Press, 1995.

Making Stories: law, literature, life. Cambridge, Harvard University Press, 2003.

Two Modes of thought. In: Actual Minds, Possible Worlds. Cambridge:

Harvard University Press, 1986

BRYDON, D. Critical literacies for globalizing times. In: Critical Literacy: Theories and Practices Vol 4:2 2010.

BUZATO, M. Letramentos em rede: textos, máquinas, sujeitos e saberes em translação. In: Revista Brasileira de Linguística Aplicada. Belo Horizonte, v. 12, n. 4, p. 783-809, 2012.

CASTEL, S.; LUKE, A.; MACLENNAN, D. On defining literacy. In: Literacy, society, and schooling. A reader. New York: Cambridge University Press, 1989. p. 3-14.

CASTELLS, M. A sociedade em rede - A era da informação: economia, sociedade e cultura; v.I). São Paulo: Paz e Terra, 2011.

CATELLI JÚNIOR,.R., GISI, B., SERRAO, L.F. S. Encceja: cenário de disputas na EJA. In: Revista Brasileira de Estudos Pedagógicos (online), Brasília, v. 94, n. 238, p. 721-744, set./dez. 2013. Disponível em: 〈http://rbep.inep.gov.br/index.php/RBEP/article/view/2853> Acesso em 30 novembro 2014.

CATELli JR, R.; HADDAD, S.; RIBEIRO, V. M. (Orgs.) Educação de Jovens e Adultos: insumos, processos e resultados. São Paulo: Ação Educativa, 2014. Disponível em < http://www.acaoeducativa.org/images/stories/pdfs/relatorio_final_INEP_EJA.pdf $>$ Acesso em 30 novembro 2014. 
CERVETTI, G., PARDALES, M.J., DAMICO, J.S. 2001. A tale of differences: comparing the traditions, perspectives, and educational goals of critical Reading and critical literacy. Reading online, 9. Em: <http://www.readingonline.org/articles/cervetti/.>Acesso em: 07 dezembro 2012.

COPE, B.; KALANTZIS, M. (Eds.) Multiliteracies: literacy learning and the design of social futures. London: Routledge, 2003.

Learning communities at work. In: New Learning: Elements of a science of education. Melbourne: Cambridge University Press, 2008.

COSTA, M.C.C. Ficção, comunicação e mídias. São Paulo, SENAC, 2002.

A apoteose da interação. Disponível em:

$<$ http://www.cibercultura.org.br/tikiwiki/tiki-read_article.php?articleId=19) $>$. Acesso em 22 novembro 2012.

Arte: resistências e rupturas. São Paulo: Moderna, 1998. v. 92. 2012.

No que você está pensando? Redes sociais e sociedade contemporânea. Revista USP CURY, L. Revisitando Morin: os novos desafios para os educadores. In: Revista Comunicação \& Educação - Ano XVII - n. 1, São Paulo, 2012.

DANTAS, M. A lógica do capital informação: a fragmentação dos monopólios e a monopolização dos fragmentos num mundo de comunicações globais. Rio de Janeiro: Contraponto, 2002.

DELGADO, L. E. \& ROLANDO, J. R, Local Histories and Global Designs: An Interview with Walter Mignolo.In. Discourse, 22.3, Fall 2000, pp. 7-33.

DERRIDA, J. O Phármakon; O Jogo do Phármakon à Letra e do Cegamento ao Suplemento. In: A Farmácia de Platão. São Paulo: Iluminuras, 1997.

Genealogy and social criticism. In: SEIDMAN, S. (Ed.) The postmodern turn: new perspectives on social theory. New York: Cambridge University Press, 1995.

Structure, Sign and Play in the Discourse of the Human Sciences. In:

Writing and Difference. UK: The Gresham Press, 1978. 
Language and Textuality. In: Modern Literary Theory, 1988.

DI PIERRO, M. C (org). Alfabetização de jovens e adultos no Brasil: lições da prática. Brasília: UNESCO, 2008.

DUBOC, A.P.M. A questão da avaliação da aprendizagem de Língua Inglesa segundo as teorias de letramentos. Dissertação (Mestrado em Estudos Linguísticos e Literários em Inglês) Faculdade de Filosofia, Letras e Ciências Humanas, Universidade de São Paulo, São Paulo, 2007.

. Atitude curricular: letramentos críticos nas brechas da formação de professores de Inglês. Tese (Doutorado em Estudos Linguísticos e Literários em Inglês) Faculdade de Filosofia, Letras e Ciências Humanas, Universidade de São Paulo, São Paulo, 2012.

DUBOC, A.P. M.; FERRAZ, D. M. Letramentos Críticos e Formação de Professores de Inglês: Currículos e Perspectivas em Expansão. In: JORDÃO, C. (org.) Letramentos e Multiletramentos no Ensino de Línguas e Literaturas. Revista X, vol.1, 2011.

ELLIS, R. Grammar Teaching - Practice or Consciousness Raising? In: RICHARDS, J.; RENANDYA, W. (eds.) Methodology in Language Teaching: An Anthology of Current Practice. New York: Cambridge University Press, 2010. pp-167-174.

FAIRCLOUGH, N. Discurso e mudança social. Brasília: Editora da UnB, 2008.

FARIA, N.R.B.; PAULA, A.S. Refletindo sobre falar e escrever em EJA. Campinas: Ministério da Educação, Cefiel/IEL/Unicamp, 2009.

FÁVERO, O. Lições da história: os avanços de 60 anos e a relação com as políticas de negação de direitos que alimentam as condições do analfabetismo no Brasil. In: PAIVA, J.; OLIVEIRA, I. B. (orgs.) Educação de Jovens e Adultos. Petrópolis, RJ: DP et Alii, 2009.

FERNANDES, J. C. A música desatando os nós no ensino de línguas. In: CONGRESSO

INTERNACIONAL DA ASSOCIAÇÃO BRASILEIRA DE LTERATURA

COMPARADA, 11, 2008, São Paulo. Anais... São Paulo, SP - Tessituras, Interações, Convergências /Sandra Nitrini... et al. - São Paulo: ABRALIC, 2008. e-book.

FERRAZ, D. M. Letramento Visual: A leitura de imagens das aulas de inglês. Jundiaí: Paco Editorial, 2012. 
FOUCAULT, M (1979). A ordem do discurso. São Paulo: Loyola, 1999.

(1981) . As palavras e as coisas. São Paulo: Martins Fontes, 2000.

FREIRE, P. (1974) Pedagogia do Oprimido. 3 ed. Rio de Janeiro: Paz e Terra, 1982.

(1992) Pedagogia da Esperança: um reencontro com a Pedagogia do Oprimido. Rio de Janeiro: Paz e Terra, 1997.

. (1996) Pedagogia da autonomia: saberes necessários à prática educativa. 39 ed. São Paulo: Paz e Terra, 2009a.

$2009 b$.

(1967). Educação como prática da liberdade. 2 ed. Rio de Janeiro: Paz e Terra,

(1995) Pedagogia da tolerância. 32 ed. Rio de Janeiro: Paz e Terra, 2013.

GEE, J. P. Situated language and learning: A critique of traditional schooling. New York, London: Routledge, 2004.

Literacy and Interpretation. In: Language and Learning in the Digital Age.

London and New York: Routledge, 2011.

The Anti-Education Era: Creating Smarter Students through Digital Learning. New York: Palgrave Macmillan, 2013.

GEERTZ, C. Thick Description: toward an interpretative theory of culture. In: .The

Interpretation of Culture: selected Essays. New York: Basic Books, 1973.

GHIRALDELLI JR., P. Filosofia e história da educação brasileira. Barueri, SP: Manole, 2003.

GIBLIN, R. O inglês por meio da música. In: LACOSTE, Y.; RAJAGOPALAN, R. (orgs.) A geopolítica do inglês. São Paulo: Parábola Editorial, 2005.

GIROUX, H; SIMON, R. (orgs.) Popular culture, schooling and everyday life. New York: Bergin \& Garvey, 1989. 
HADDAD, S. e DiPIERRO, M.C. Escolarização de jovens e adultos. In: Revista Brasileira de Educação, Mai/Jun/Jul/Ago 2000 Nº 14.

HALL, S. The question of Cultural Identity. In: HALL, S.; HELD, D.; MCGREW, T. Modernity and its futures. London: Polity Press/Open University Press, 1992.

The centrality of culture: notes on the cultural revolutions of our time. In.:THOMPSON, Kenneth (ed.). Media and cultural regulation. London, Thousand Oaks, New Delhi: The Open University; SAGE Publications, 1997. Publicado em Revista Educação \& Realidade Trad. Ricardo Uebel, Maria Isabel Bujes e Marisa Vorraber Costa.

HEATH, S.B.; STREET, B. On Ethnography: Approaches to Language and Literacy Research (An NCRLL Volume). New York: Language and Literacy Series, 2007.

IDDINGS, A. Forging connections and reconceptualizing diversity in L2 education. São Paulo: DLM/USP. 04 fevereiro 2013. Apresentação oral (Workshop).

JANKS, H. et al. Doing critical literacy: texts and activities for students and teachers. New York, London: Routledge, 2014.

JORDÃO, C. Abordagem comunicativa, pedagogia crítica e letramento crítico - farinhas do mesmo saco? In: ROCHA, C. H.; MACIEL, R. F. (orgs.) Língua Estrangeira e Formação Cidadã: por entre discursos e práticas. Campinas, SP: Pontes Editores, 2013.

KALANTZIS, M; COPE, B. Literacies. New York: Cambridge University Press, 2012. Multiliteracies in Education. In: CHAPPELLE, C.A. (Ed.) The Encyclopedia of Applied Linguistics. Blackwell Publishing Ltd., 2013. Multiliteracies: New Literacies, New Learning. In: Pedagogies: An International Journal, Vol.4, 2009, pp.164-195. . (Eds.) Ubiquitous Learning. Urbana and Chicago: University of Illinois Press, 2010.

KONDER, L. O que é dialética. São Paulo: Editora Brasiliense, 1990.

KRESS, G. Literacy in the New Media Age. London: Routledge, 2003. 
Communication: shaping the domain of meaning. In:

Multimodality: A

social semiotic approach to contemporary communication. London and New York: Routledge, 2011.

. Meaning as resource: 'naming' in a multimodal social-semiotic theory. In:

Multimodality: A social semiotic approach to contemporary communication. London and New York: Routledge, 2011a.

Multimodal orchestrations and ensembles of meaning. In:

Multimodality:

A social semiotic approach to contemporary communication. London and New York: Routledge, 2011b.

KRESS, G. VAN LEEUWEN, T. (1996) Reading images: the grammar of visual design. London: Routledge, 2006.

KRESS, G. Literacy in the new media age. New York: Routledge, 2003.

KUMARAVADIVELU, B. A linguística aplicada na era da globalização. In: MOITA LOPES, L. P. (org.) Por uma linguística aplicada INdisciplinar. São Paulo: Parábola Editorial, 2011.

Individual identity, cultural globalization, and teaching English as an international language; The case for an epistemic break. In: ALSAGOFF, S. L. MCKAY, G. HU, \&. RENANDYA, W. A (Eds.), Principles and practices for teaching Englsih as an international language (pp. 9-27). New York: Routledge, 2012.

LANDIM, D. S. P.; ONO, F. T. P. Tecnologias digitais, letramentos e a colaboração na formação de professores. Revista X, [S.1.], v. 2, jun. 2014. Disponível em: $<$ http://ojs.c3sl.ufpr.br/ojs2/index.php/revistax/article/view/34789>. Acesso em: 18 julho 2014.

LANGE, C.P. Formulação ensino-aprendizagem na fala-em-interação de sala de aula de inglês como língua adicional na educação de jovens e adultos. Dissertação (Mestrado em Linguística Aplicada) - Instituto de Letras, Universidade Federal do Rio Grande do Sul, Porto Alegre, 2010.

LANKSHEAR, C.; KNOBEL, M. Pesquisa pedagógica: do projeto à implementação. Porto Alegre: Artmed, 2008.

New Literacies: Everyday Practices and Classroom Learning. Glasgow: Open University Press, 2006. 
New Literacies: Everyday Practices and Social Learning. Berkshire, England: Open University Press Mc Graw-Hill Education, 2011.

LARAIA, R. B. Cultura: Um conceito antropológico. Rio de Janeiro: Jorge Zahar, 2008.

LEANDER, K. New architectures for learning that travels physical and virtual spaces. São Paulo: DLM/USP. 04 fevereiro 2013. Apresentação oral (Workshop).

LEANDER, K.M., MCKIM, K.K. Tracing the Everyday 'Sitings' of Adolescents on the Internet: a strategic adaptation of ethnography across online and offline spaces. In:

Education, Communication \& Information, Vol. 3, No. 2, July 2003. Routledge, 2003.

LEMKE, J. L. Letramento metamidiático: transformando significados e mídias. In: Trabalhos de linguística aplicada. [online]. 2010, vol.49, n.2 (pp. 455-479) . Disponipvel em:

$<$ http://www.scielo.br/scielo.php?script=sci_arttext\&pid=S0103-

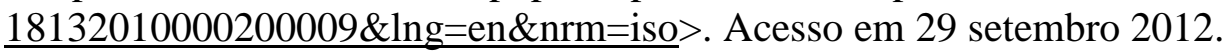

LEU, D. J.; KINZER, C. K.; COIRO, J. L.; CAMMACK, D.W. Toward a Theory of New Literacies Emerging From The Internet and Other Information and Communication Technologies. In: Theoretical Models and Processes of Reading. Newark: International Reading Association, 2004.

LIMA, D. C. (org.) Inglês em escolas públicas não funciona? Uma questão, múltiplos olhares. São Paulo: Parábola Editorial, 2011.

LUKE, C. Media literacy and cultural studies. In: MUSPRATT, S.; LUKE, A.; FREEBODY, P. (eds.) Constructing critical literacies: teaching and learning textual practice. Cresskill, New Jersey: Hampton Press, 1997.

LUKE, A.; FREEBODY, P. Critical literacy and the question of normativity: an Introduction. In: MUSPRATT, S.; LUKE, A.; FREEBODY, P. Constructing critical literacies: teaching and learning textual practice. Cresskill: Hampton Press, 1997.

CASTELL, S; LUKE, A.; MACLENNAN, D. On defining literacy. In: CASTELL, S. LUKE, A.; EGAN, K. (eds.). Literacy, Society and Schooling: A reader. Cambridge, Cambridge University Press, 1989.

LUKE, A.; FREEBODY, P. Shaping the social practices of Reading. In: MUSPRAT, S.; LUKE, A.; FREEBODY, P. (Eds.) Constructing critical literacies: teaching and learning textual practice. Cresskill: Hampton Press, 1997. 
Critical literacy and the question of normativity: an introduction. In: MUSPRATT,

S.; LUKE, A.; FREEBODY, P. Constructing critical literacies: teaching and learning textual practice. Cresskill: Hampton Press, 1997.

LUKE, C. Media literacy and cultural studies. In: MUSPRATT, S.; LUKE, A.; FREEBODY, P. (eds.) Constructing critical literacies: teaching and learning textual practice. Cresskill, New Jersey: Hampton Press, 1997

MACHADO, A. O efeito Zapping. In: Máquina e Imaginário. São Paulo: EDUSP, 1996.

MAGNANI, Luiz Henrique. Um passo para fora da sala de aula: novos letramentos, mídias e tecnologias. Revista X, [S.1.], v. 1, n. 1, nov. 2011. ISSN 1980-0614. Disponível em: <http://ojs.c3sl.ufpr.br/ojs/index.php/revistax/article/view/23248/16913 >. Acesso em: 15 janeiro 2014.

MARREIRO, S.C.R. Investigando Concepções de Língua e Cultura no Ensino de Inglês na Escola Pública Segundo as Teorias de Letramentos. Dissertação (Mestrado em Estudos Linguísticos e Literários em Inglês) - Faculdade de Filosofia, Letras e Ciências Humanas, Universidade de São Paulo, São Paulo, 2012.

MATTOS, A.M.A. O Ensino de Inglês como Língua Estrangeira na Escola Pública: Novos Letramentos, Globalização e Cidadania. Tese (Doutorado em Estudos Linguísticos e Literários em Inglês) - Faculdade de Filosofia, Letras e Ciências Humanas, Universidade de São Paulo, São Paulo, 2011.

MCLUHAN, M. Os meios de comunicação como extensões do homem. São Paulo: Cultrix 2005.

MENEZES DE SOUZA, L. M. T.; MONTE MÓR, W. Orientações Curriculares do Ensino Médio: Línguas Estrangeiras, Linguagens, Códigos e Tecnologias. Brasília: MEC/SEB, 2006.

MENEZES DE SOUZA, L. M. T. Para uma redefinição de Letramento Crítico: conflito e produção de significação. In: MACIEL, R.F \& ARAÚJO, V.A. (orgs). Formação de Professores de Línguas: ampliando perspectivas. São Paulo: Paco Editorial, 2011. pp.128140.

MIGNOLO, W. Cosmopolitanism and the De-colonial Option (2010) 29:111-127. In: Studies of Philosophy and Education, University of Oslo, Institute do Educational Research.

MOLLICA, M. C. \& LEAL, M. Letramento em EJA. São Paulo: Parábola Editorial, 2009. 
MONTE MÓR,W. Linguagem digital e interpretação: perspectivas epistemológicas. In:

Revista Trabalhos em Linguística Aplicada n. 46 (1). Campinas: Editora da Unicamp, 2007.

. Globalização, ensino de língua inglesa e educação crítica. In: SILVA, K. A. (org). A Educação de Professores de Línguas Contemporâneas. Campinas: Editora Pontes, 2012.

Reading Dogville in Brazil: image, language and critical literacy. In: MENEZES DE SOUZA (Ed.) Special edition: Language, Cultural, Multimodality and Dialogic Emergence. London: Multilingual Matters, 2006.

Investigating Critical Literacy at the University in Brazil. In: Critical Literacies. London, 2007. Disponível em < $\underline{w w w . c r i t i c a l l i t e r a c y . o r g . u k}>$ Acesso em 03 junho 2012.

Linguagem tecnológica e educação: em busca de práticas para uma formação crítica. In: SIGNORINI, I. (org.) Linguagem e Letramentos. Belo Horizonte: UFMG, 2012.

. The development of agency in a new literacies proposal for teacher education in Brazil. In: JUNQUEIRA, E.S.; BUZATO, M. (eds.) New literacies, new agencies? A Brazilian perspective on mindsets, digital practices and tools for social action in and out of school. New York: Peter Lang, 2013.

MORIN, E. A alma no cinema. In: MACHADO, A. Máquina e Imaginário. São Paulo: EDUSP, 1996.

A cabeça bem-feita: repensar a reforma, reformar o pensamento. Rio de Janeiro: Bertrand Brasil, 2010.

NEW LONDON GROUP. A Pedagogy of Multiliteracies: Designing Social Futures. In:

Harvard Educational Review vol.66 no. 1, 1996. Disponível em $\langle$ http://www.pwrfaculty.net/summer-seminar/files/2011/12/new-london-multiliteracies.pdf $>$ Acesso em 26 outubro 2012.

PAIVA, J.; OLIVEIRA, I. B. (orgs.) Educação de Jovens e Adultos. Petrópolis, RJ: DP et Alii, 2009.

PENNYCOOK, A. Uma linguística aplicada transgressiva. In: MOITA LOPES, L. P. (org.) Por uma linguística aplicada INdisciplinar. São Paulo: Parábola, 2006. 
PRADO, V.V. Construindo um espaço de vivência e aprendizagem na aula de Inglês na EJA. Dissertação (Mestrado em Linguística Aplicada) Instituto de Letras, Universidade Federal do Rio Grande do Sul, Porto Alegre, 2011.

RAJAGOPALAN, K. Por um linguística crítica: linguagem, identidade e a questão ética. São Paulo: Parábola Editorial, 2003.

REAGAN, T. (2009). Objectification, positivism and language studies: A reconsideration. Critical Inquiry in Language Studies, 1(1), 41-60.

RIBEIRO JR., J. O que é positivismo. São Paulo: Editora Brasiliense, 1982.

RICOUER, P. Da Linguagem, do Símbolo e da Interpretação; O Conflito das Interpretações; Método hermenêutico e filosofia reflexiva. In: Da Interpretação: Ensaio sobre

Freud. Rio de Janeiro: Editora Imago, 1977.

. Introdução: Existência e Hermenêutica; Hermenêutica e Estruturalismo. In: O Conflito das Interpretações: Ensaios de Hermenêutica. Rio de Janeiro: Editora Imago, 1978.

ROJO, R. Letramentos múltiplos, escola e inclusão social. São Paulo: Parábola Editorial, 2009.

SANTIAGO, C. A. B. Uma situação de aprendizagem de língua inglesa com alunos de EJA: percepções sobre uma unidade didática e a aprendizagem. Dissertação (Mestrado em Linguística Aplicada e Estudos da Linguagem). Pontifícia Universidade Católica, São Paulo, 2008.

SANTOS, B. S. Um Discurso sobre as Ciências. Porto: Afrontamento, 1988.

Para além do pensamento abissal: das linhas globais a uma ecologia dos saberes. In:

Revista Novos Estudos, nov. 2007.

SARTORI, A. Legislação, políticas públicas e concepções de Educação de Jovens e Adultos. In: LAFFIN, M.H.L.F. (org.) Educação de Jovens e Adultos e Educação na Diversidade. Florianópolis. UFSC. 2011. 
SÃO PAULO (SP). Secretaria Municipal de Educação. Diretoria de Orientação Técnica. Caderno de Orientações didáticas para EJA Língua Estrangeira - Inglês: etapas complementar e final - São Paulo: SME / DOT, 2010.

Secretaria Municipal de Educação. Diretoria de Orientação Técnica. Orientações

Didáticas: Alfabetização e Letramento - EJA e MOVA. São Paulo: SME / DOT, 2007a.

Secretaria Municipal de Educação. Diretoria de Orientação Técnica.

Orientações Curriculares: expectativas de aprendizagem para Educação de Jovens e

Adultos - EJA. São Paulo: SME / DOT, 2007b.

SETTON, M. G. J. A cultura popular no Brasil: a cultura de massa. In: Revista USP, São

Paulo, n.61, p. 58-77, março/maio 2004.

Um novo capital cultural: pré-disposições e disposições à cultura informal nos

segmentos com baixa escolaridade. Revista Educação e Sociedade, Campinas, v. 26, n.

90, Abril 2005 . Disponível em

$<$ http://www.scielo.br/scielo.php?script=sci_arttext\&pid=S0101-

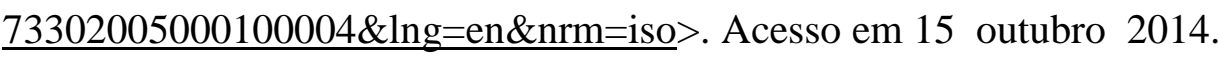

SOARES, M. Letramento em ensaio - Letramento: como definir, como avaliar, como medir. In:___ Letramento - Um tema em três gêneros. Belo Horizonte: Autêntica, 2005.

Letramento e Escolarização. In: RIBEIRO, V. M. (org.). Letramento no Brasil. São

Paulo: Global, 2003, p. 89-113.

TAKAKI, N.H. Letramentos na sociedade digital: navegar é e não é preciso. Tese

(Doutorado em Estudos Linguísticos e Literários em Inglês) Faculdade de Filosofia, Letras e

Ciências Humanas, Universidade de São Paulo, São Paulo, 2011.

THOMPSON, J.B. A mídia e a modernidade. Rio de Janeiro: Vozes, 1998.

UECHI, S.A. Inglês: disciplina-problema nos níveis fundamental e médio? Dissertação (Mestrado em Estudos Linguísticos e Literários) - Faculdade de Filosofia, Letras e Ciências Humanas , Universidade de São Paulo, São Paulo, 2006. 
VELASCO, M. T. Q. V. Tecnologias Digitales: para la educacion y la comunicación. In: CURY, Lucilene (org) Tecnologias digitais nas interfaces da comunicação/educação: desafios e perspectivas. Curitiba: CRV, 2012.

VENTURA, J. Educação ao longo da vida e organismos internacionais: apontamentos para problematizar a função qualificadora da Educação de Jovens e Adultos. Revista Brasileira de Educação de Jovens e Adultos, Vol. 1, nº 1, 2013.

VIGOTSKI, L. S.; LURIA, A. R. ; LEONTIEV, A. N. Linguagem, desenvolvimento e aprendizagem. São Paulo: Ícone, 2010.

\section{SITES CONSULTADOS:}

$<\underline{\text { http://sistemasideb.inep.gov.br/resultado/> }}$ Acesso em 30 de novembro de 2014.

<http://portalsme.prefeitura.sp.gov.br. $>$ Acesso em 27 julho 2014. 
ANEXOS

Anexo 1 - Atividade sobre alimentação (CENTRO EDUCACIONAL TRANSDISCIPLINAR)

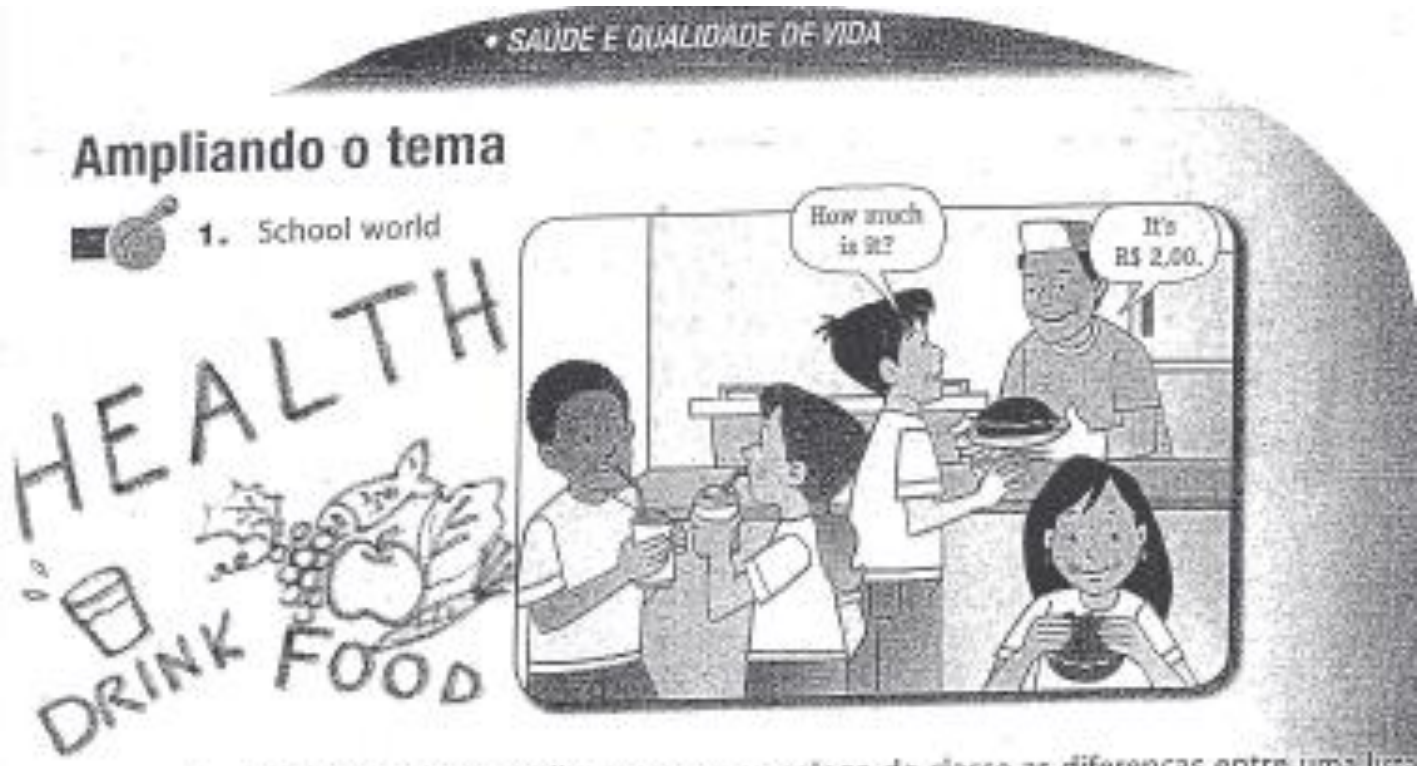

2. Observe, compare e discuta com seu colega de classe as diferenças entre ums list outra.

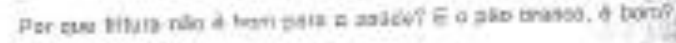

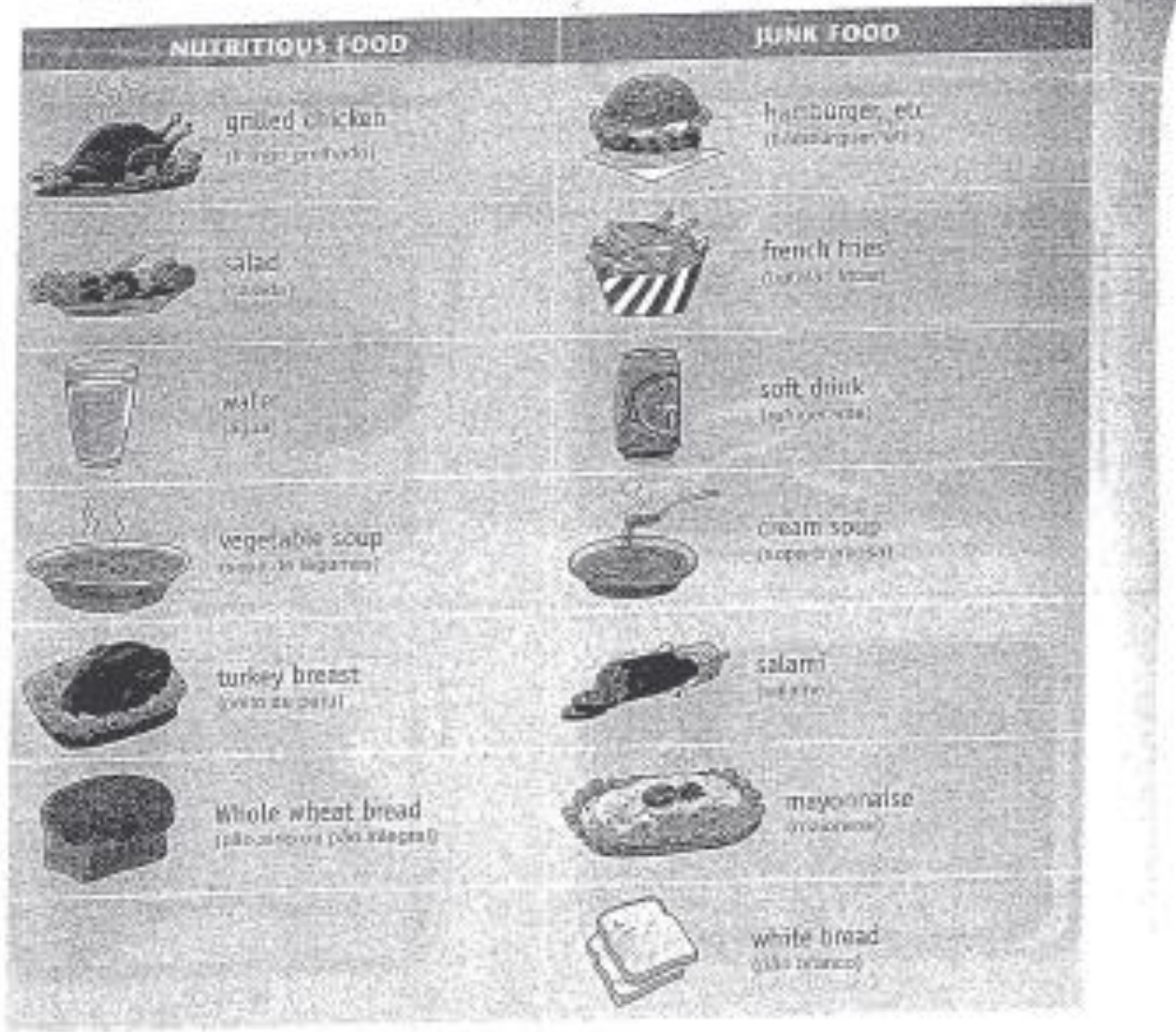




\section{Anexo 2 - Atividade preparatória para avaliação $3^{\text {a }}$ Etapa}

\section{(CENTRO EDUCACIONAL TRANSDISCIPLINAR)}

Name:

EF

Group:

\section{PROVA DE LEM - INGLÊS}

1. Qual o assunto do infográfico?
a) Os nutrientes e as calorias dos alimentos.
b) Hábitos alimentares em diferentes culturas.
c) Os ingredientes de um produto alimentício.
d) Alimentação não saudável.
e) Os grupos de alimentos e o quanto se deve comer de cada um.

Responda às perguntas 2 e 3 com base na tabela.

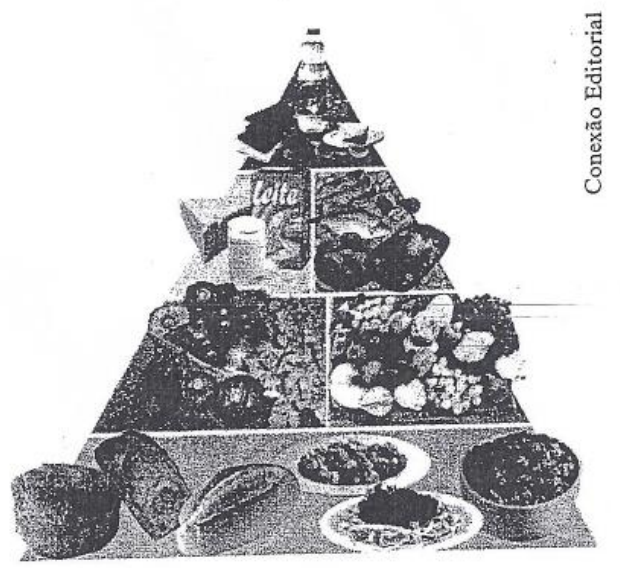

2. Com base na tabela nutricional, complete o texto a seguir, utilizando apenas uma palavra em cada espaço. Veja o exemplo:

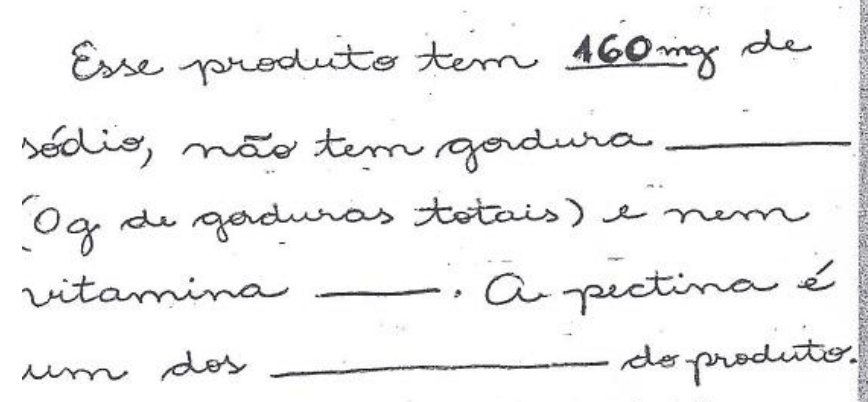

3. Onde você encontra esse tipo de tabela?

4. Qual das seguintes alternativas melhor descreve um café da marthã típico no Brasil?
a) scrambled eggs, bacon, cereal
b) bread, butter, milk
c) burger, fries, soda
d) rice, beans, salad, fried egg
e) breakfast

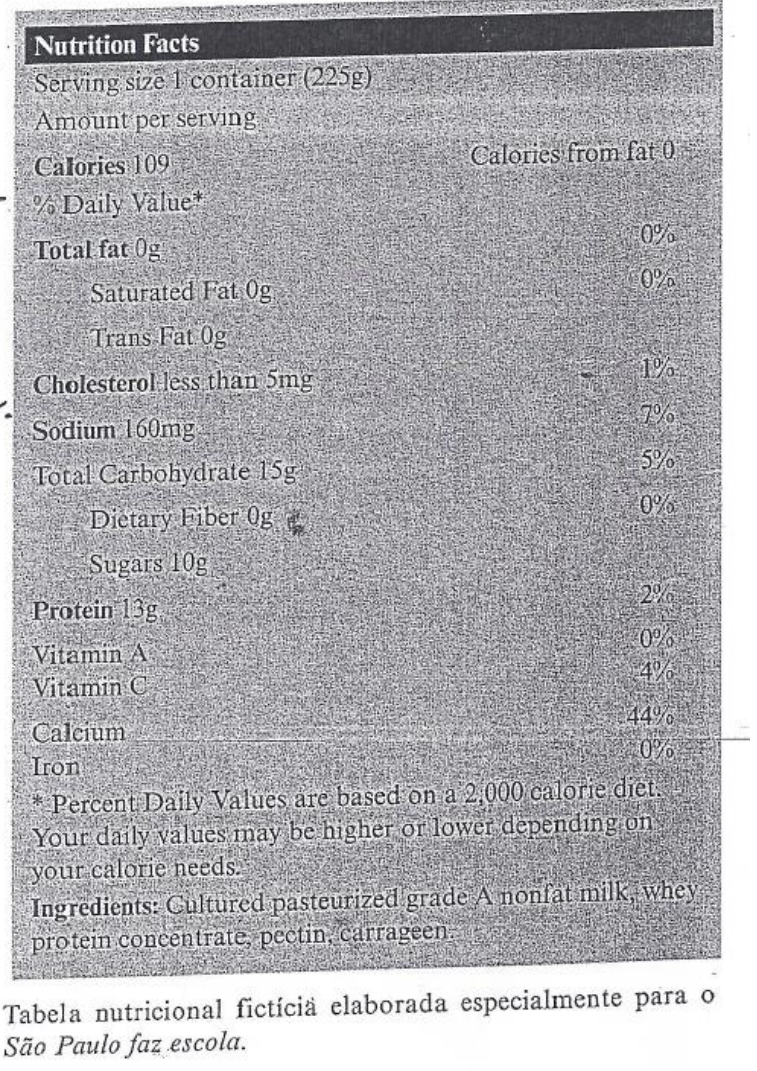


Anexo 3 - Avaliação $3^{\text {a }}$ Etapa (CENTRO EDUCACIONAL TRANSDISCIPLINAR)

Nome:

Módúlo:

\section{AVALIAÇĀO DE INGLÊS (Lingua Estrangeira Moderna)} Laia a tabela nutricicnal abeiko reiativa e um paso doce de padaria e a piramide de almentos para responder As
questces soguintes:

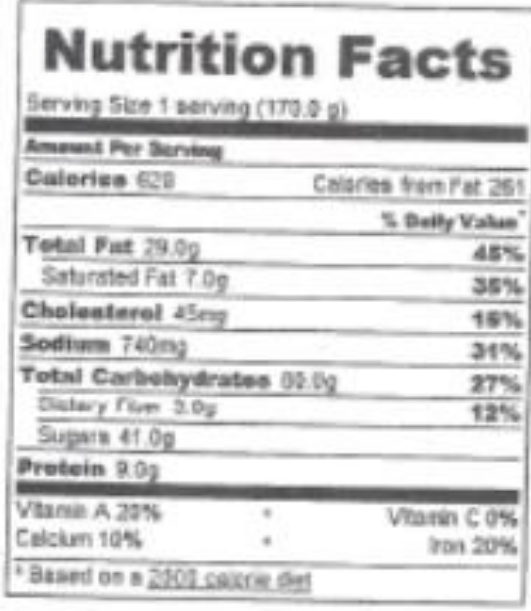

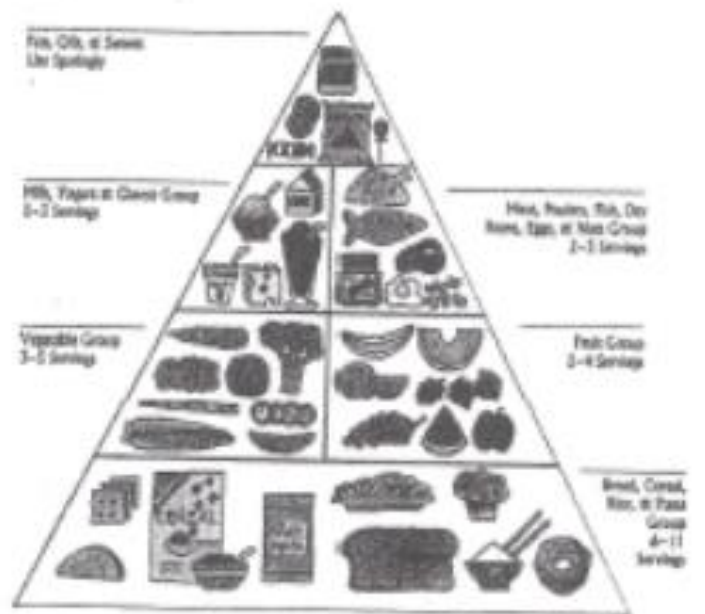

1. Neste alimento há gordura saturada? Quantos gramas? Quantos por cento (\%) de gorduras totais serlio consumidas por quem desse produto se alimentar?

2. Dentre as Vitaminas $A$ e Vitamina $C$, o Calcio e o Ferro, qual desses nutrientes nalo há em quantidade suficiente para entrar na porcentagę̣ diária de consumo
necessário?

3. Comparando a tabela nutricional desse produto com a pirârmide alimentår (ao lado) a qual apresenta no topo os alimentos que devem ser consumidos em menor quantidade e, na base, aqueles que devem ser mais consumidos, além de nossos estudos sobre alimentaçto saudável ("Health food" e "Nutritional Food"); reflita:

Você consumiria esse produto? Por quê??

Boa prova!l! 
Anexo 4 - Canção "What a wonder world" (CENTRO EDUCACIONAL TRANSDISCIPLINAR)

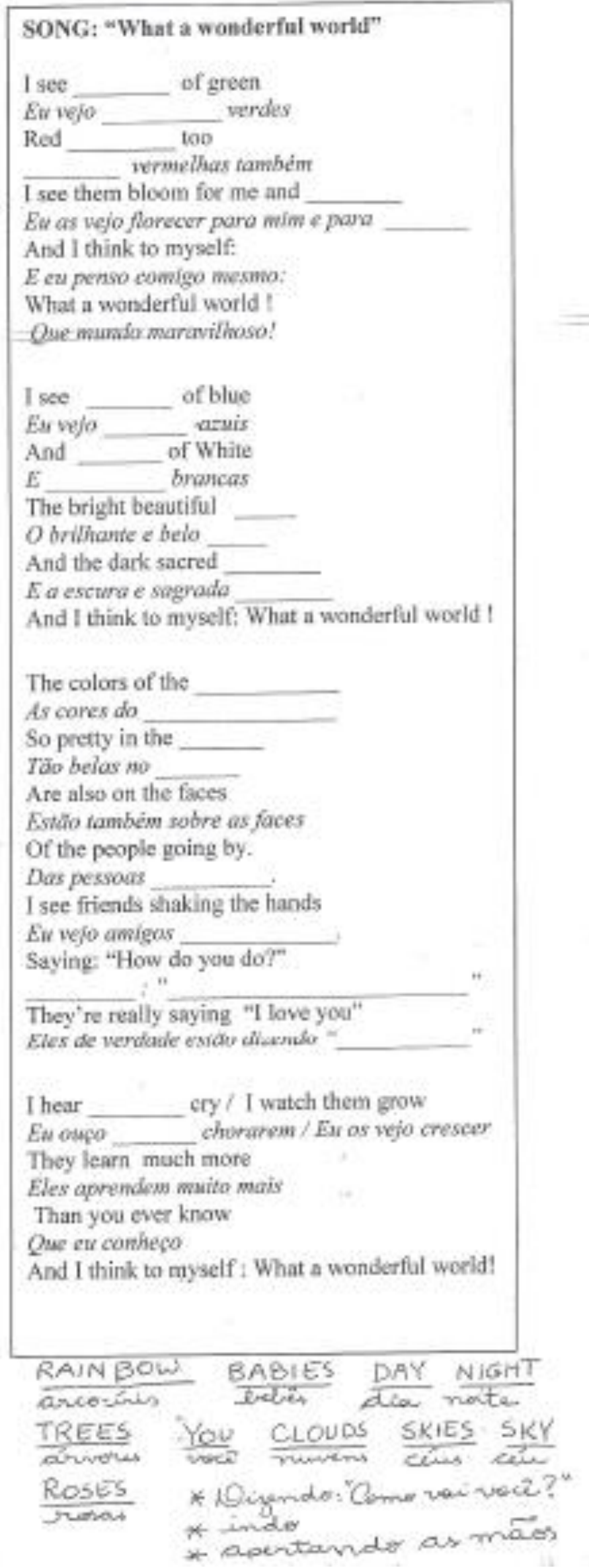




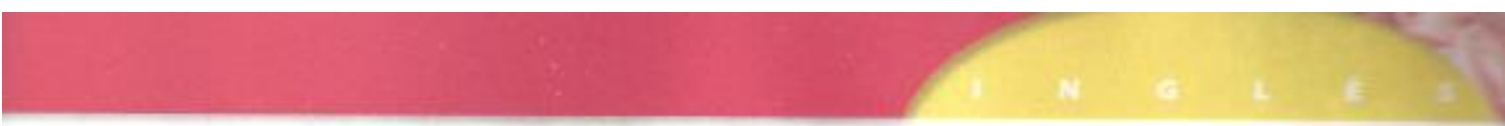

\section{Desvendando o tema}

ar

1. What is this?

What is that?

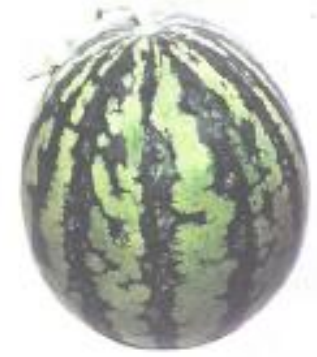

This is a watermelon. It's a watermelon.

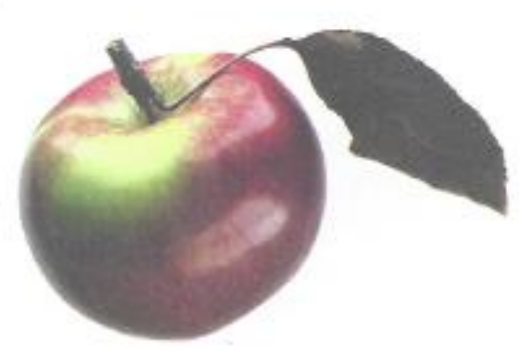

That is an apple.

It's an apple.

What are those?

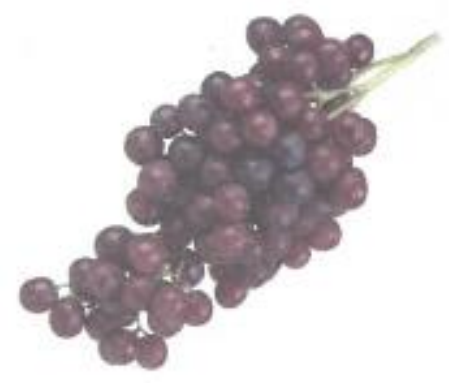

These are grapes.

They're grapes.

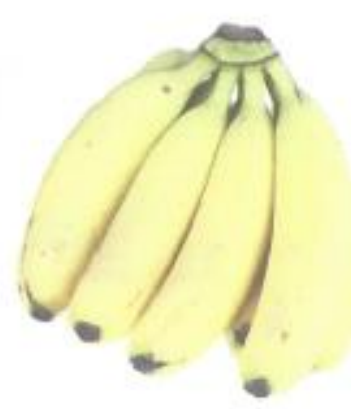

Those are bananas.

They're bananas.

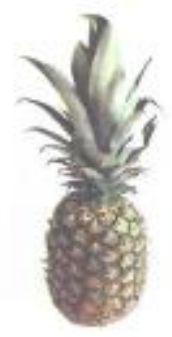

pineapple

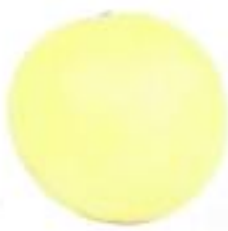

melon

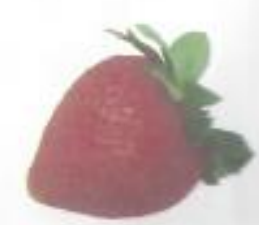

strawberry 
Anexo 6 - Canção "You are my sunshine" (CENTRO EDUCACIONAL TRANSDISCIPLINAR)

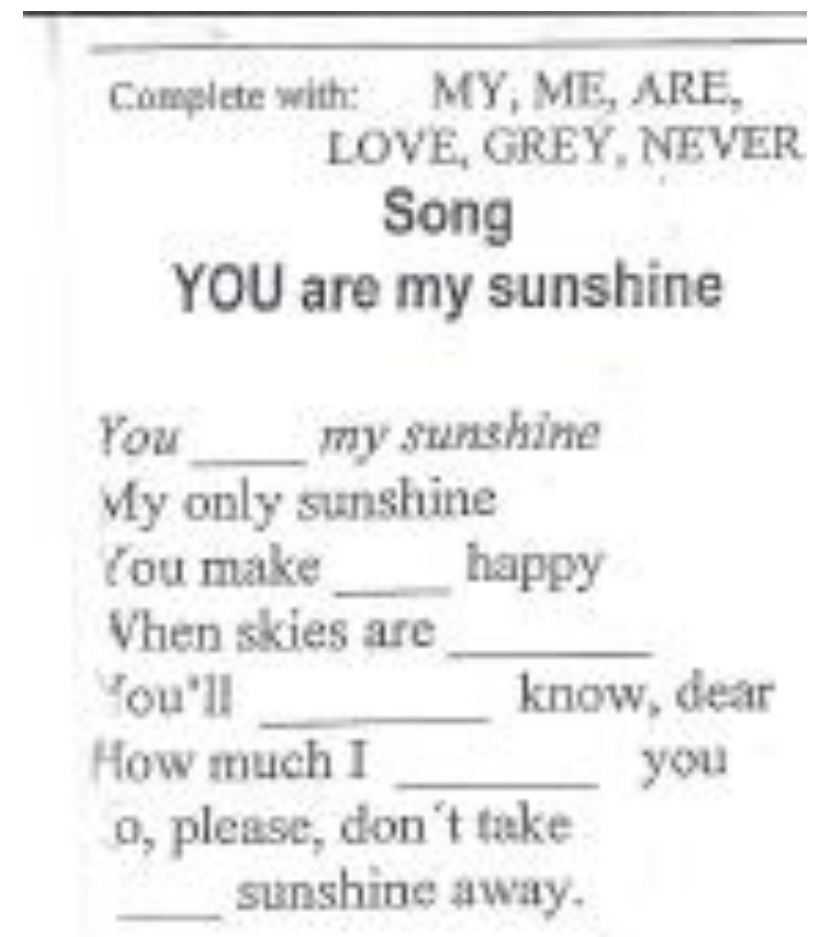


Anexo 7 - Tabela com verbo to be (CENTRO EDUCACIONAL TRANSDISCIPLINAR)

\section{UNIDADE $1 \cdot$ IDENTIDADE}

2. Pergunte aos seus colegas:

A: Where are you from?

B: I'm from...

Agora, que tal conhecer as formas do verbo "TO BE" (ser/estar)? Preste atenção às explicaçōes ala seu educador.

Forma afirmativa
I am
You are
He is
She is
It is
We are
You are
They are

\section{Forma negativa}

I am not

You are not

He is not

She is not

It is not

We are not

You are not

They are not

\section{Forma interrogativa}

Am I?

Are you?

Is he?

Is she?

Is it?

Are we?

Are you?

Are they?

\section{Forma contraida}

I'm (not)

You're (not) / You aren't

He's (not) / He isn't

She is (not) / She isn't

It is (not) / It isn't

We're (not) / We aren't

You're (not) / You aren't

They're (not) / They aren't 
Anexo 8 - Texto usado em atividade sobre o Halloween (EMEF PAULO FREIRE)

\begin{tabular}{|c|c|}
\hline A & $\begin{array}{l}\text { Halloween } \\
\text { Conhecido como "Dia das Bruxas", teve sua origem nas festas } \\
\text { pagãs entre a civilização celta, povo cuja cultura e religião } \\
\text { dominaram grande parte da Europa durante muitos séculos. Quando } \\
\text { os celtas ocuparam a Inglaterra e a Irlanda, eles acreditavam que na } \\
\text { noite de } 31 \text { de outubro, véspera do início do inverno naquela região, } \\
\text { maus espíritos rondavam a Terra e pregavam peças nos seres } \\
\text { humanos. }\end{array}$ \\
\hline B & $\begin{array}{l}\text { stindo-se de bruxos e fantasmas, os celtas imaginavam que, } \\
\text { sim, estariam confundindo os maus espiritos. Eles acreditavam } \\
\text { e que naquela noite todas as passagens entre os mundos dos } \\
\text { ortos e dos vivos eram abertas. }\end{array}$ \\
\hline C & $\begin{array}{l}\text { dos magos e das feiticeiras. Para } \\
\text { seres amados falecidos, faziam-se } \\
\text { ou Soul Cakes (originando depois o } \\
\text { s dias. No segundo dia tinha início o } \\
\text { no ( } 2 \text { de novembro) era dedicado ao } \\
\text { origem do nome: All saints day eve, } \\
\text { l, Halloween. }\end{array}$ \\
\hline D & $\begin{array}{l}\text { Séculos depois, os irlandeses acrescentaram à tradição grupos de } \\
\text { pessoas fantasiando-se de monstros, bruxos e seres sobrenaturais } \\
\text { e indo de casa em casa, pedindo alimentos para as festividades do } \\
\text { Halloween. Batiam de porta em porta e diziam trick or treat (que } \\
\text { significa algo como "me dê um doce ou lhe fazemos uma } \\
\text { travessura"). }\end{array}$ \\
\hline$E$ & $\begin{array}{l}\text { símbolo do Halloween é Jack-o'-lantern. Jack é uma moranga ou } \\
\text { óbora, entalhada com cara de fantasma, com uma vela dentro } \\
\text { ra ficar iluminada. Usada para decorar jardins e varandas das } \\
\text { sidências, sua função é afugentar os espíritos maus e demais } \\
\text { res sobrenaturais. Hoje em dia, o Halloween é uma festa muito } \\
\text { perada e comemorada principalmente pelos norte-americanos, } \\
\text { ee fazem festas e se fantasiam. As crianças saem pelas ruas, } \\
\text { tendo às portas das casas para pedir doces e balas. Muitas } \\
\text { lanças fazem doações dos doces que recolhem para instituições } \\
\text { antrópicas. }\end{array}$ \\
\hline
\end{tabular}




\section{Anexo 9 - Letra com atividade e tradução da canção Strange Fruit (EMEF PAULO FREIRE)}

Strange. Fruit (Biliie Holida
Southern trees bear strange
Blood on the leaves and

breeze, bodies swinging in the southern

Strange fruit hanging from the poplar

- Pastoral scene of the gallant

The bulging

Scent of magnolias,

Then the sudden

and the twisted mouth, and fresh, of burning flesh.

Here is fruit for the crows to pluck,

For the to gather, for the wind to suck, For the to rot, for the trees to drop,

Here is a strange and crop

\section{Fruto Estranho (Billie Holiday)}

Árvores do sul produzem um fruto estranho, Sangue nas folhas e sangue nas raízes, Corpos negros balançando na brisa do sul, Frutos estranhos penduradas nos álamos.

Cena pastoril do valente sul,

Os olhos inchados e a boca torcida, Perfume de magnólias, doce e fresca, Então o repentino cheiro de carne queimando.

Aqui está a fruta para os corvos arrancarem, Para a chuva recolher, para o vento sugar, Par o sol apodrecer, para as árvores derrubarem, Aqui está a estranha e amarga colheita. 
Anexo 10 - Avaliação para a $3^{\text {a }}$ Etapa (EMEF PAULO FREIRE)

Name:

Number:

Group:

Teacher

- Date:

THE HUMAN BODY

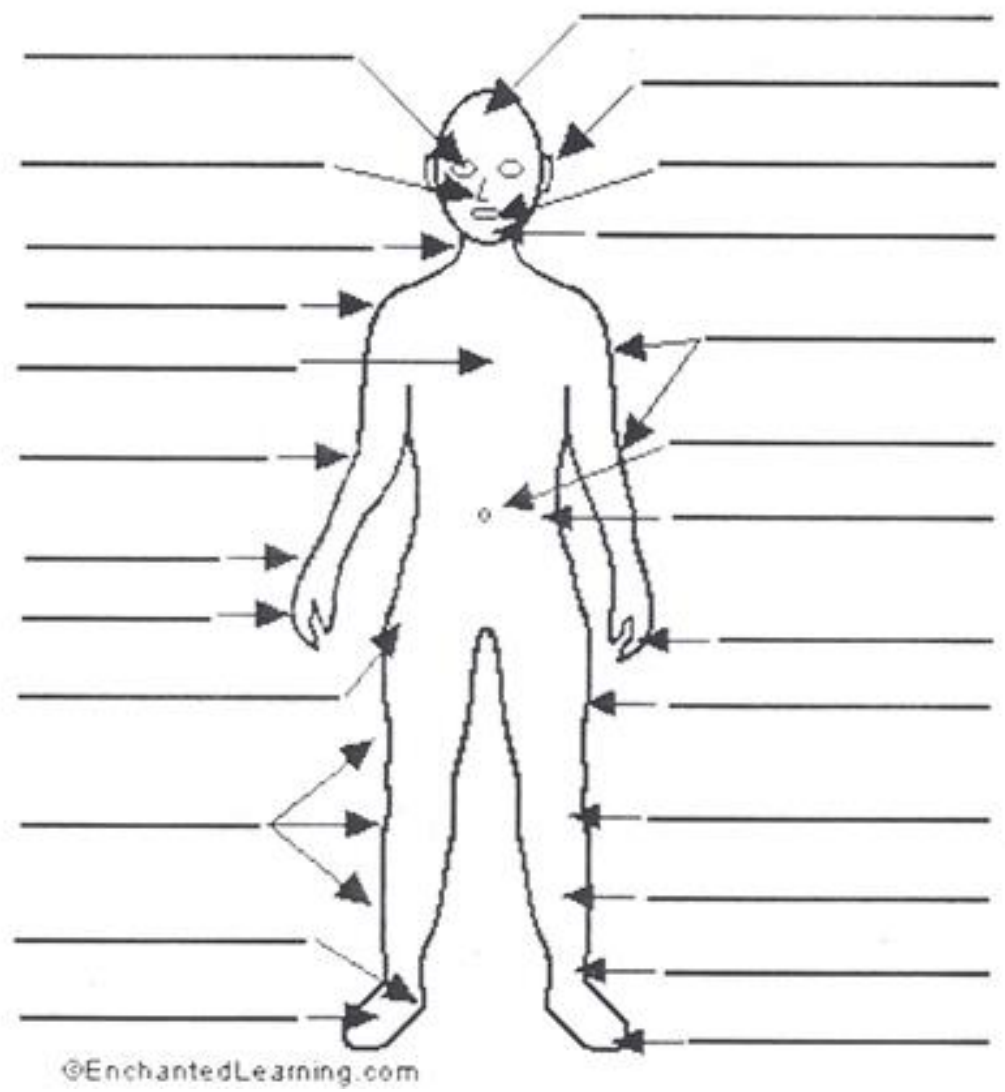


Anexo 11 - Avaliação para a $4^{\mathrm{a}}$ Etapa (EMEF PAULO FREIRE)

Name:

Number:

Group:

Teacher -Date:

THE HOUSE

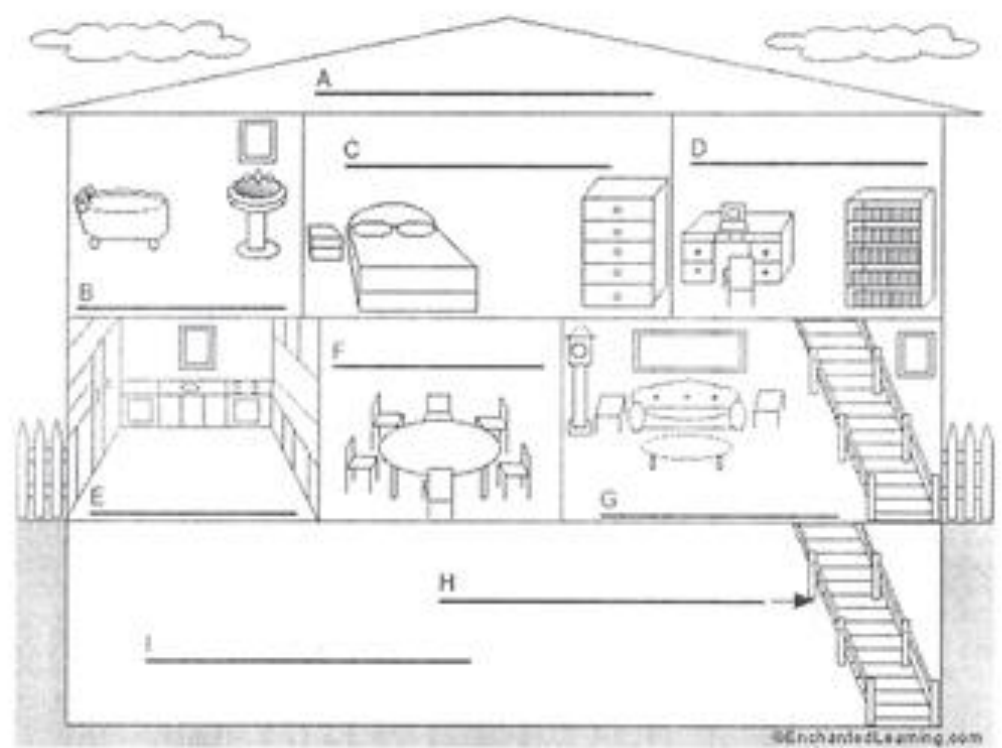




\section{APÊNDICES}

Apêndice 1: Organização das aulas observadas

\begin{tabular}{|c|c|c|c|c|c|c|}
\hline & Escola & \multicolumn{2}{|c|}{ Turma } & Período & Professora & \\
\hline \multirow{6}{*}{ 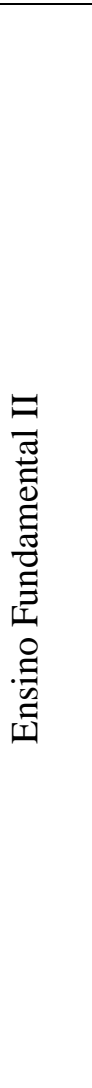 } & $\begin{array}{c}\text { Centro } \\
\text { Educacional } \\
\text { Trandisciplinar }\end{array}$ & A & $\begin{array}{c}3^{\circ} \\
\text { Módulo } \\
\text { A }\end{array}$ & Manhã & Vívian & 10 \\
\hline & $\begin{array}{c}\text { Centro } \\
\text { Educacional } \\
\text { Trandisciplinar }\end{array}$ & B & $\begin{array}{c}3^{\circ} \\
\text { Módulo } \\
\text { D }\end{array}$ & Manhã & Vívian & 9 \\
\hline & $\begin{array}{c}\text { Escola } \\
\text { Municipal Paulo } \\
\text { Freire }\end{array}$ & $\mathrm{C}$ & $\begin{array}{c}3^{\mathrm{a}} \text { Etapa } \\
\text { A }\end{array}$ & Noite & Milena & 26 \\
\hline & $\begin{array}{c}\text { Escola } \\
\text { Municipal Paulo } \\
\text { Freire }\end{array}$ & $\mathrm{D}$ & $\begin{array}{c}3^{\mathrm{a}} \text { Etapa } \\
\text { B }\end{array}$ & Noite & Milena & 8 \\
\hline & $\begin{array}{c}\text { Escola } \\
\text { Municipal Paulo } \\
\text { Freire }\end{array}$ & $\mathrm{E}$ & $\begin{array}{c}4^{\mathrm{a}} \text { Etapa } \\
\text { A }\end{array}$ & Noite & Milena & 13 \\
\hline & $\begin{array}{c}\text { Escola } \\
\text { Municipal Paulo } \\
\text { Freire }\end{array}$ & $\mathrm{F}$ & $\begin{array}{c}4^{\mathrm{a}} \text { Etapa } \\
\text { B }\end{array}$ & Noite & Milena & 11 \\
\hline Total & & & & & & 77 \\
\hline
\end{tabular}

Tabela 1 - Aulas observadas 
Nome: Idade:

Escola: Etapa: Data:

Caro aluno,

Ao responder a este questionário, você está participando de uma pesquisa que investiga o uso de língua inglesa entre os alunos de EJA desta escola. Muito obrigada por sua colaboração!

1- Por que você decidiu estudar na EJA?

( ) Falta de tempo ( ) Dificuldades financeiras ( ) Dificuldades familiares $\quad(\quad)$ Não precisou estudar antes

( ) Exigência do mercado de trabalho ( ) Outros. Qual?

2 - Qual o seu objetivo com relação aos estudos?

3 - Você acessa a Internet? （） Sim （） Não

4 - Se você respondeu sim à pergunta 3 , com que frequência você acessa a Internet?

( )Mais de 1 vez ao dia ( ) Todo dia ( ) 2 a 3 vezes por semana ( ) 1 vez por semana ( ) Raramente

5 - De onde você costuma acessar?

( )Tablet ( )Celular ( )PC ( )Notebook ( )Lan house ( )Trabalho ( )Escola (

)Telecentro

6 - Que sites você costuma acessar?

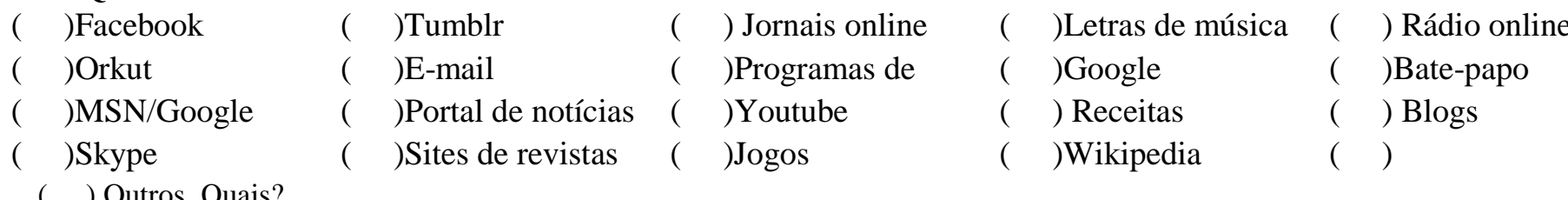

( ) Outros. Quais?

7 - O que você costuma aprender na internet?

8 - Você já teve que ler algo em inglês na internet? Como lidou com isso? O que você aprende na escola te ajudou?

9 - Qual a importância da língua inglesa no mundo de hoje? Qual a importância da língua inglesa para a sua vida?

10 - Você acha que o que você aprende na escola e na internet podem te ajudar com os objetivos que você apontou na pergunta 2? Por quê? Considere especialmente a língua inglesa.

a) Você gostaria de participar de um questionário por e-mail? （） Sim （）Não

Se sim, deixe seu E-mail:

b) Você gostaria de participar de uma entrevista? ( ) Sim （）Não

c) O que você achou dessas perguntas? Se quiser, use o verso desta folha para fazer comentários. 
Apêndice 3 - Tabulação dos dados

Tabela 2A - Alunos participantes por Sexo: CENTRO EDUCACIONAL TRANDISCIPLINAR

\begin{tabular}{|c|c|c|}
\hline Sexo & Frequência & Porcentagem \\
\hline Feminino & 11 & $57,89 \%$ \\
\hline Masculino & 8 & $41,1 \%$ \\
\hline Total & 19 & $100 \%$ \\
\hline
\end{tabular}

Tabela 2B: Alunos participantes por Sexo: ESCOLA MUNICIPAL PAULO FREIRE

\begin{tabular}{|c|c|c|}
\hline Sexo & Frequência & Porcentagem \\
\hline Feminino & 31 & $53,45 \%$ \\
\hline Masculino & 27 & $46,55 \%$ \\
\hline Total & 58 & $100 \%$ \\
\hline
\end{tabular}

Tabela 3A: Faixa etária dos alunos participantes CENTRO EDUCACIONAL TRANDISCIPLINAR

\begin{tabular}{|c|c|c|}
\hline Faixa Etária & Frequência & Porcentagem \\
\hline Abaixo de 20 anos & 3 & $15,78 \%$ \\
\hline De 20 a 30 anos & 1 & $5,26 \%$ \\
\hline De 30 a 40 anos & 5 & $15,79 \%$ \\
\hline De 40 a 50 anos & 3 & $15,79 \%$ \\
\hline De 50 a 60 anos & 3 & $21,05 \%$ \\
\hline Acima de 60 anos & 4 & $100 \%$ \\
\hline Total & 19 & \\
\hline
\end{tabular}

Tabela 3B: Faixa etária dos alunos participantes ESCOLA MUNICIPAL PAULO FREIRE

\begin{tabular}{|c|c|c|}
\hline Faixa Etária & Frequência & Porcentagem \\
\hline Abaixo de 20 anos & 12 & $20,69 \%$ \\
\hline De 20 a 30 anos & 10 & $17,24 \%$ \\
\hline
\end{tabular}




\begin{tabular}{|c|c|c|}
\hline De 30 a 40 anos & 15 & $25,86 \%$ \\
\hline De 40 a 50 anos & 9 & $15,51 \%$ \\
\hline De 50 a 60 anos & 7 & $12,07 \%$ \\
\hline Acima de 60 anos & 5 & $8,62 \%$ \\
\hline Total & 58 & $100 \%$ \\
\hline
\end{tabular}

Tabela 4: Área de atuação profissional dos alunos participantes

\begin{tabular}{|c|c|c|}
\hline Área de Atuação Profissional & Frequência & Porcentagem \\
\hline Ajudante de cozinha & 1 & $1,3 \%$ \\
\hline Ajudante geral & 1 & $1,3 \%$ \\
\hline Aposentado & 2 & $2,6 \%$ \\
\hline Atendente & 4 & $5,19 \%$ \\
\hline Autônomo & 1 & $1,3 \%$ \\
\hline Auxiliar de sala & 1 & $1,3 \%$ \\
\hline Auxiliar de serviço geral & 1 & $1,3 \%$ \\
\hline Cabeleireiro & 2 & $2,6 \%$ \\
\hline Consultor de vendas de produtos cosméticos & 1 & $1,3 \%$ \\
\hline Costureiro & 2 & $2,6 \%$ \\
\hline Cozinheiro & 1 & $1,3 \%$ \\
\hline Dona de casa & 8 & $10,4 \%$ \\
\hline Eletricista & 1 & $1,3 \%$ \\
\hline Entregador & 1 & $1,3 \%$ \\
\hline Estudante & 6 & $7,8 \%$ \\
\hline Faxineiro & 1 & $1,3 \%$ \\
\hline Garçom & 3 & $3,9 \%$ \\
\hline Gerente de Vendas & 1 & $1,3 \%$ \\
\hline
\end{tabular}




\begin{tabular}{|c|c|c|}
\hline Maître & 1 & $1,3 \%$ \\
\hline $\begin{array}{c}\text { Manutenção e instalação de acessórios } \\
\text { automotivos }\end{array}$ & 1 & $1,3 \%$ \\
\hline Mecânico & 1 & $1,3 \%$ \\
\hline Metalúrgico & 1 & $1,3 \%$ \\
\hline Monitor de turismo & 1 & $1,3 \%$ \\
\hline Pedreiro & 1 & $1,3 \%$ \\
\hline Pintor & 2 & $2,6 \%$ \\
\hline Promotor & 1 & $1,3 \%$ \\
\hline Recepcionista & 1 & $1,3 \%$ \\
\hline Repositor & 1 & $1,3 \%$ \\
\hline Taxista & 1 & $1,3 \%$ \\
\hline Técnico operacional & 1 & $1,3 \%$ \\
\hline Trabalhador doméstico, babá, diarista & 9 & $11,69 \%$ \\
\hline Vendedor & 1 & $1,3 \%$ \\
\hline Vigilante & 1 & $1,3 \%$ \\
\hline Não respondeu & 14 & $18,18 \%$ \\
\hline Total & 77 & $100 \%$ \\
\hline
\end{tabular}

Tabela 5 - Por que está estudando na EJA? CENTRO EDUCACIONAL TRANDISCIPLINAR, alunos participantes

\begin{tabular}{|c|c|}
\hline Motivo & Frequência \\
\hline Exigência do mercado de trabalho & 6 \\
\hline Falta de tempo & 5 \\
\hline Dificuldades financeiras & 3 \\
\hline
\end{tabular}




\begin{tabular}{|c|c|}
\hline Dificuldades familiars & 1 \\
\hline Não precisou estudar antes & 1 \\
\hline Outros: & \\
Porque trabalho à tarde. & \\
Não havia escola. & \\
Reciclagem. & \\
Falta de interesse. & \\
\hline
\end{tabular}

Tabela 6 - Por que está estudando na EJA? ESCOLA MUNICIPAL PAULO FREIRE, alunos participantes

\begin{tabular}{|c|c|}
\hline Motivo & Frequência \\
\hline Exigência do mercado de trabalho & 33 \\
\hline Falta de tempo & 18 \\
\hline Dificuldades financeiras & 3 \\
\hline Dificuldades familiares & 9 \\
\hline Não precisou estudar antes & 1 \\
\hline \multicolumn{2}{|c|}{ Outros: } \\
\hline \multicolumn{2}{|c|}{ Falta de oportunidade. } \\
\hline \multicolumn{2}{|c|}{ Porque minha mãe me colocou na $1^{\mathrm{a}}$ série com 11 anos. } \\
\hline \multicolumn{2}{|c|}{ Fiquei sozinha e procurei ocupar meu tempo na escola. } \\
\hline \multicolumn{2}{|c|}{ Meus pais não tinham condição. } \\
\hline \multicolumn{2}{|c|}{ Quero realizar um sonho de ser professora. } \\
\hline \multicolumn{2}{|c|}{ Vontade de aprender. } \\
\hline \multicolumn{2}{|c|}{ Para me desenvolver melhor no mercado de trabalho. } \\
\hline
\end{tabular}




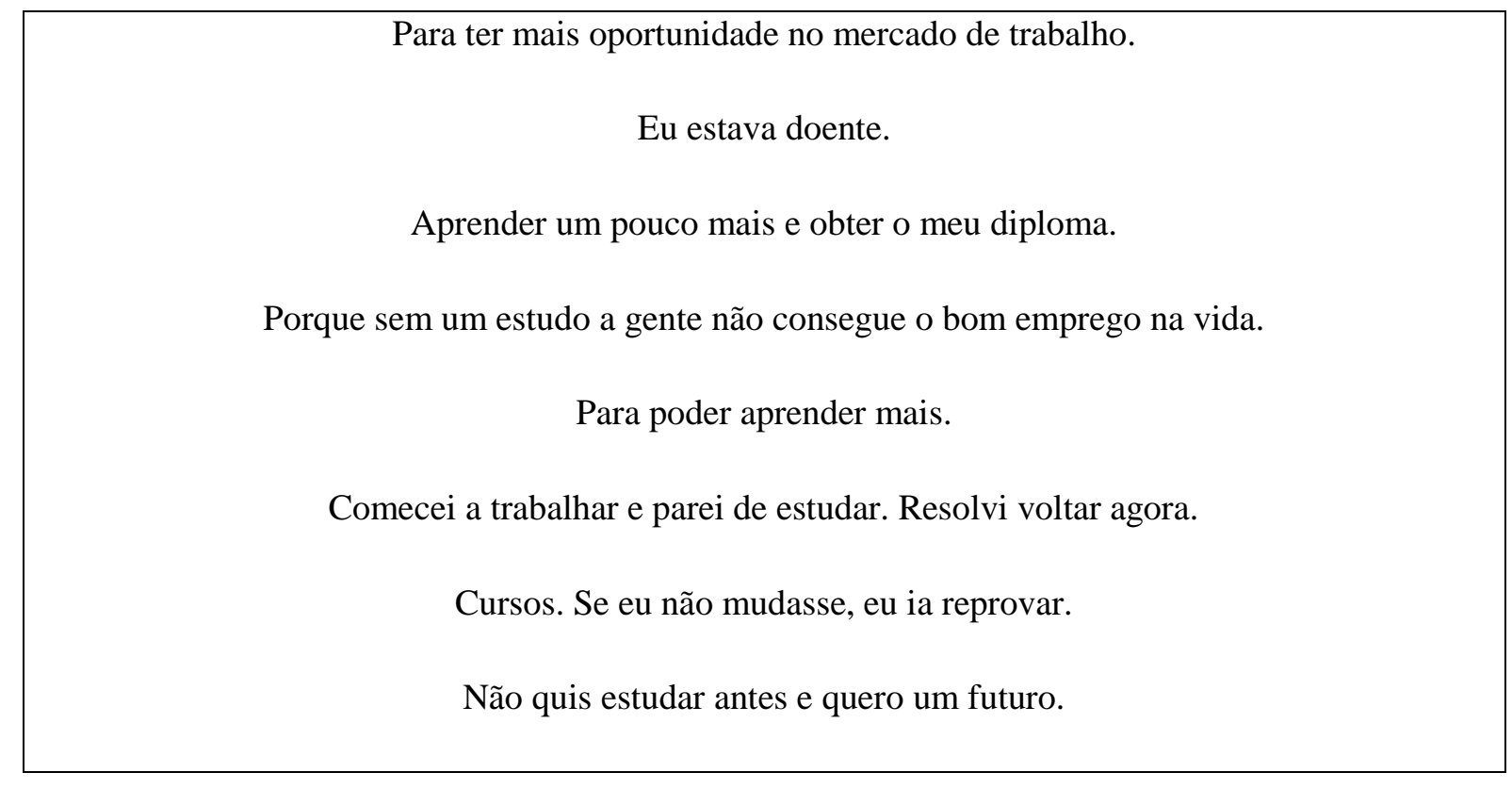

\section{Respostas - Qual o seu objetivo com relação aos estudos? Alunos participantes CENTRO EDUCACIONAL TRANDISCIPLINAR}

A1 - Terminar os meus estudos e ter mais conhecimento.

A2 - Concluir uma faculdade e conseguir um trabalho melhor.

A3 - Fazer um curso de gastronomia.

A4 - Buscar mais conhecimento no mundo [em que] vivo. Não está claro se é isso o que quis dizer.

A5 - Meu objetivo é continuar com meus estudos até o ensino médio.

A6 - É de obter mais conhecimento e crescer na vida.

A7 - Em aprender a ler e escrever corretamente.

A8 - Melhorar a qualidade de vida em todos os sentidos.

A9 - Porque estudar é muito bom, às vezes você não trabalha, fica sem fazer nenhuma atividade, não é bom para a saúde e memória.

A10 - Conseguir meu diploma do [ensino] fundamental.

B1 - Ir ao mercado de trabalho.

B2 - Conseguir evoluir na carreira profissional.

B3 - Terminar o ensino médio, fazer um ensino superior.

B4 - A minha relação com os estudos: completar a faculdade.

B5 - Melhorar a minha condição financeira. 
B6 - Meu objetivo é arrumar um serviço melhor.

B7 - Conseguir uma posição melhor no mercado de trabalho.

B8 - Continuar.

B9 - Meu objetivo em relação aos estudos é terminar eles e ser alguém na vida.

C1 - O meu objetivo é estudar, me formar e ter um bom futuro.

$\mathrm{C} 2-(\mathrm{em}$ branco $)$

C3 - Terminar e fazer faculdade.

C4 - Continuar estudando.

C5 - Aprender.

C6 - Terminar meus estudos e depois correr atrás de uma faculdade para me preparar para Pedagogia.

C7 - Porque quero fazer faculdade, quero ir um pouco mais além, também tenho alguns objetivos a realizar.

C8 - Eu quero fazer um curso.

C9 - Eu vou terminar o estudo porque eu quero fazer um curso de auxiliar de enfermagem.

C10 - O meu objetivo é ter outra profissão, no caso a do meu sonho.

C11 - Pedagogia.

C12 - O meu objetivo é continuar estudando.

C13 - O meu objetivo é aprender mais para ter condições e oportunidades melhores.

C14 - O meu objetivo é melhor conhecimento e uma qualificação melhor.

C15 - Aprender mais na sala de aula.

C16 - O objetivo é continuar.

C17 - Sempre aprender mais.

C18 - Terminar os meus estudos, fazer faculdade e trabalhar.

C19 - Meu objetivo é aprender mais sabedorias, inteligência.

C20 - (em branco)

C21 - (em branco)

C22 - Para ter mais informação no dia a dia.

C23 - (em branco)

C24 - Terminar o estudo e fazer um curso de enfermagem.

C25 - O meu objetivo com relação aos estudos é aprender mais e aproveitar o tempo perdido e poder aproveitar as oportunidades de crescer no futuro e aproveitar o tempo perdido. 
C26 - Eu quero aprender muito mais.

D1 - O trabalho.

D2 - Meu objetivo é estudar bastante e no futuro cursar uma faculdade.

D3 - Terminar os estudos e arrumar um serviço melhor.

D4 - Em melhorar de vida.

D5 - Quero terminar todos os estudos para fazer a minha faculdade de auxiliar administrativo.

D6 - Ter um trabalho melhor.

D7 - Terminar estudo, fazer faculdade.

D8 - Pretendo terminar os meus estudos e fazer um curso.

E1 - Cursar uma faculdade e ter um bom trabalho.

E2 - Aprender as disciplinas e suas normas, técnicas para um objetivo de alcançar faculdade de direito. [44 anos]

E3 - Terminar os estudos e fazer uma faculdade de engenharia. [17 anos[

E4 - É terminar os estudos e fazer um curso.

E5 - Chegar a fazer faculdade e ter um ótimo futuro.

E6 - Arrumar um bom trabalho.

E7 - É estudar bastante para conseguir um bom emprego e é bom estudar.

E8 - O meu objetivo com relação aos estudos é para aprender mesmo, porque quando eu era mais nova não tive chance de estudar.

E9 - Para aperfeiçoar o estudo e aprender as lições novas e para conseguir terminar o estudo.

E10 - Aumentar o meu conhecimento.

E11 - Arrumar um emprego melhor.

E12 - Meu objetivo é estudar para ser alguém na vida e pretendo terminar meus estudos.

E13 - É melhorar de vida, trabalhar em um emprego bom, e ter conhecimentos, ser inteligente e crescer no futuro.

F1 - Terminar meus estudos, fazer faculdade e me tornar professor de matemática.

F2 - Meu objetivo é ser um profissional na área de trabalho.

F3 - Terminar os estudos e conseguir fazer alguns cursos ou faculdade, para ter um bom emprego.

F4 - Me formar (concluir os estudos). E tentar entender o professor por ele avançar muito rápido no módulo.

F5 - Primeiramente, aprender e devido ao mercado de trabalho estar muito exigente.

F6 - Meu maior objetivo é conseguir um trabalho com qualidade no qual posso sustentar eu e meus filhos.

F7 - Terminar os estudos, fazer uma faculdade, ter uma profissão, ser alguma coisa na vida. 
F8 - Aprender para ser enfermeira.

F9 - Eu gostaria de terminar e fazer um curso de enfermagem.

F10 - O meu objetivo é aprender.

F11 - Meu objetivo maior é entrar no mercado de trabalho e adquirir conhecimento.

Tabela 9 A: Frequência de uso da Internet: Alunos participantes CENTRO EDUCACIONAL

TRANDISCIPLINAR

\begin{tabular}{|c|c|}
\hline Frequência de uso & Alunos \\
\hline Uma vez por semana & 7 \\
\hline Mais de uma vez por dia & 4 \\
\hline Todo dia & 3 \\
\hline Raramente & 3 \\
\hline De duas a três vezes por semana & 1 \\
\hline
\end{tabular}

Tabela 9 B: Frequência de uso da Internet: Alunos participantes ESCOLA MUNICIPAL PAULO FREIRE

\begin{tabular}{|c|c|}
\hline Frequência de uso & Alunos \\
\hline Todo dia & 13 \\
\hline Raramente & 13 \\
\hline Uma vez por semana & 12 \\
\hline De duas a três vezes por semana & 9 \\
\hline Mais de uma vez por dia & 6 \\
\hline
\end{tabular}

Tabela 10A: De onde se acessa a Internet - 19 Alunos participantes CENTRO EDUCACIONAL TRANDISCIPLINAR

\begin{tabular}{|c|c|}
\hline Opções & Alunos \\
\hline Tablet & 1 \\
\hline Celular & 2 \\
\hline PC & 5 \\
\hline Notebook & 4 \\
\hline Lan House & 2 \\
\hline Trabalho & 1 \\
\hline Escola & 8 \\
\hline Telecentro & 0 \\
\hline
\end{tabular}


Tabela 10B: De onde se acessa a Internet - 58 Alunos participantes ESCOLA MUNICIPAL PAULO FREIRE

\begin{tabular}{|c|c|}
\hline Opções & Alunos \\
\hline Tablet & 2 \\
\hline Celular & 12 \\
\hline PC & 22 \\
\hline Notebook & 9 \\
\hline Lan House & 10 \\
\hline Trabalho & 4 \\
\hline Escola & 33 \\
\hline Telecentro & 1 \\
\hline
\end{tabular}

Tabela 11A: Sites e conteúdos mais acessados pelos 19 alunos participantes CENTRO EDUCACIONAL TRANDISCIPLINAR

\begin{tabular}{|c|c|}
\hline Sites e conteúdos & Alunos \\
\hline Facebook & 11 \\
\hline Google & 8 \\
\hline E-mail & 5 \\
\hline Youtube & 5 \\
\hline Jornais online & 3 \\
\hline Orkut & 3 \\
\hline Portal de notícias & 3 \\
\hline Programas de TV & 3 \\
\hline Receitas culinárias & 3 \\
\hline Bate-papo & 2 \\
\hline Jogos & 2 \\
\hline Rádio online & 2 \\
\hline Blogs & 1 \\
\hline Letras de música & 1 \\
\hline MSN & 1 \\
\hline Sites de cifra de música & 1 \\
\hline Wikipedia & 1 \\
\hline Outros (em branco) & 3 \\
\hline
\end{tabular}

Tabela 11B: Sites mais acessados pelos 58 alunos participantes ESCOLA MUNICIPAL PAULO FREIRE

\begin{tabular}{|c|c|}
\hline Sites e conteúdos & Alunos \\
\hline Google & 38 \\
\hline E-mail & 29 \\
\hline
\end{tabular}




\begin{tabular}{|c|c|}
\hline Youtube & 27 \\
\hline Facebook & 25 \\
\hline Orkut & 16 \\
\hline Portal de notícias & 16 \\
\hline $\mathrm{MSN}$ & 15 \\
\hline Jogos & 11 \\
\hline Letras de músicas & 11 \\
\hline Receitas culinárias & 11 \\
\hline Jornal online & 9 \\
\hline Programas de TV & 8 \\
\hline Rádio online & 7 \\
\hline Bate-papo & 6 \\
\hline Wikipedia & 6 \\
\hline Revistas & 4 \\
\hline Blogs & 3 \\
\hline Skype & 2 \\
\hline Baixar músicas e videos & 1 \\
\hline Esportes & 1 \\
\hline Programas evangélicos & 1 \\
\hline Sites de lojas e ofertas & 1 \\
\hline Tumblr & 1 \\
\hline Twitter & 1 \\
\hline Outros (em branco) & 1 \\
\hline
\end{tabular}

Pergunta 7 - O que você costuma aprender na Internet?

A1 - Digitar.

A2 - Sobre cursos, trabalhos, artesanato, notícias e informação.

A3 - Pesquisar.

A4 - Pegar receitas e pesquisar artesanato.

A5 - Na Internet eu aprendo várias coisas.

A6 - A digitar textos e planilhas e outras coisas mais.

A7 - Escrever.

A8 - Trabalhos artesanais.

A9 - Nada. 64 anos 
A10 - A tocar músicas no violão.

B1 - (em branco)

B2 - Nada favorável, por falta de tempo.

B3 - (em branco)

B4 - Eu pretendo aprender na internet muito mais, principalmente nos teclados.

B5 - A ler melhor.

B6 - A pesquisar e a ficar por dentro das notícias.

B7 - Eu aprendi a ficar informado das coisas que acontecem no dia a dia.

B8 - A utilizar.

B9 - Diversas coisas, como o que está acontecendo pelo mundo inteiro.

C1 - Pesquisas, notícias, etc.

C2 - Pesquisar.

C3 - Fazer trabalho da escola.

C4 - Pesquisar sobre política e fazer trabalhos escolares.

C5 - Várias coisas.

C6 - Ler, escrever, passar todos os exercícios que a professora passa para nós.

C7 - Eu aprendo de tudo, pois na Internet tem de tudo.

C8 - Receita culinária, pesquisa no Google.

C9 - Procurar alguma coisa que eu preciso no Google.

C10 - Aprendo a pesquisar, a interagir com o mundo de hoje (faz parte).

C11 - Fazer trabalho da escola.

C12 - Fazer pesquisas para trabalho de escola e outros.

C13 - Eu costumo verificar quais são os... (em branco)

C14 - Notícias e pesquisas sobre outras coisas.

C15 - Falar com amigo e bate-papo.

C16 - Trabalho e pesquisa.

C17 - Nada. Eu só pesquiso alguma coisa sobre o que a professora pede e o que me chama a atenção. (Sr E.)

C18 - A mexer no Orkut, no MSN, no Facebook e no Youtube. (15 anos)

C19 - Na Internet tem muita coisa nova, a cada dia a gente aprende mais. Nunca enjoa.

C20 - (em branco) 
C21 - (em branco)

$\mathrm{C} 22$ - (em branco)

C23 - Trabalho da escola. 59 anos

C24 - Eu pesquisei os CEUs.

C25 - Eu costumo abrir o meu e-mail na escola para abrir as tarefas da prof. E ver as notícias, ver fotos, ver jornais, pesquisar reciclagem, o lixo, direitos humanos.

C26 - (em branco)

D1 - Trabalho de escola.

D2 - Estudo, fazer amizade e às vezes ver notícia, ouvir música no Youtube. (18 anos)

D3 - Músicas e jogos.

D4 - Muita coisa importante para o meu futuro.

D5 - Eu aprendo na Internet receitas, trabalho de escola, letras de músicas, etc.

D6 - Faço trabalho escolar.

D7 - (em branco)

D8 - Eu pesquiso muito na Internet!

E1 - Pesquiso muito sobre matemática. Estudo com frequência.

E2 - Eu costumo aprender a digitar corretamente e ficar por dentro das novidades.

E3 - De tudo um pouco. A Internet só não faz por nós, mas o que você quiser fazer e não souber, pode procurar na Internet que tem!!!

D4 - Pouca coisa, porque mexo pouco na Internet, tipo... aprimoro meus conhecimentos sobre alguns programas de utilidade própria.

D5 - Aprender receitas, tiro dúvidas em relação a algumas lições feitas na escola.

D6 - Pesquisa de estudos, trabalhos escolares e além de estudar em sala de aula na escola, procuro no Youtube vídeos de professores que ensinam, principalmente matemática. 27 anos, costureira.

D7 - Pesquisar mais sobre o que estou estudando, ou alguma coisa que não sei o que significa, e até como me vestir ou comportar em público. 24 , dona de casa.

D8 - (em branco)

D9 - (em branco)

E1 - Ler texto.

E2 - Várias receitas, busco informações sobre oportunidade de emprego, escuto músicas, pesquiso notícias de reportagem, previsão do tempo e falo com amigos através do Facebook. 31 anos, dona de casa.

E3 - Aprender a fazer comidas diferentes. 
E4 - Aulas de pinturas residenciais, móveis, técnicas para instalação elétrica residencial.

E5 - Nada. 17 anos.

E6 - Eu costumo aprender a mexer no computador e na Internet.

E7 - Várias coisas.

E8 - Eu aprendo a letra da música.

E9- Várias coisas.

E10 - (em branco)

E11 - Muitas coisas como culinária, notícias, novelas, filme e pesquisa.

E12 - Na verdade, eu uso a Internet raramente, para pesquisa de escola ou quando preciso procurar algum endereço.

E13 - Eu não costumo aprender nada a não ser aprender a língua de Internet, mas só aprendo quando a prof. Alice manda lição por e-mail.

F1 - Aprendo muitas coisas na Internet. Receitas culinárias, como comprar pela Internet e outras coisas mais.

F2 - Aprendo a descobrir coisas, conhecer lugares, aprender coisas, ver coisas diferentes. 17 anos.

\section{Pergunta 8 - Você já teve que ler algo em Inglês na Internet? Como lidou com isso? O que você aprende na escola te ajudou?}

A1 - Eu tom aprendi muitas coisas na escola.

A2 - Sim, algumas palavras conhecidas em inglês ajuda muito, devemos assistir filmes em inglês e tentar decifrar aos poucos.

A3 - Sim. Achei difícil.

A4 - (em branco)

A5 - Sim

A6 - Não. Nunca prestei atenção nessa parte.

A7 - Eu ainda não aprendi quase nada.

A8 - Sim, algumas palavras muito comuns.

A9 - Sim, ajudou muito, espero aprender mais.

A10 - Não

B1 - (em branco)

B2 - Não

B3 - Sim, ajudou muito.

B4 - Nunca precisei ler inglês. Sim, oportunidade de voltar a estudar. 
B5 - Ajudou muito!

B6 - Não.

B7 - Sim, muito. Algumas palavras consultei na internet como falar e pronunciar as palavras corretas.

B8 - (em branco)

B9 - Não.

C1 - Sim, eu aprendi muitas coisas que eu não sabia em inglês.

C2 - Não

C3 - Sim. Me ajudou bastante.

C4 - Não.

C5 - Não.

C6 - Eu já vi, mas não sim porque.

C7 - Não, até este momento.

C8 - Já pesquisei, foi difícil mas consegui. O que aprendi na escola me ajudou bastante pois não sabia nada.

C9 - Sim, fui no meu caderno pesquisar o que eu aprendi aqui na escola.

C10 - Sim, lidei de uma maneira tranquila pois o conhecimento que estou tendo na escola é muito bom (mas preciso muito mais e vou correr atrás disso).

C11 - Não

C12 - Sim, eu já li algumas palavras em inglês e o que eu aprendi na escola me ajudou bastante.

C13 - (em branco)

C14 - Sim, mais ou menos, sim.

C15 - (em branco)

C16 - Sim, tranquilo, sim.

C17 - Não. Tudo o que eu leio vem traduzido para Português.

C18 - Me ajudou muito a aprender inglês.

C19 - Eu aprendi a ler texto comprido que a professora Alice passou para nós.

C20 - (em branco)

C21 - (em branco)

C22 - (em branco)

C23 - Sim, me ajudou muito. Escrevo melhor, falo melhor e leio melhor.

C24 - Sim, me ajudou um pouco, mas pretendo aprender mais. 
C25 - (em branco)

C26 - (em branco)

D1 - (em branco)

D2 - Sim, ajudou muito. Aprendi a falar mais, pouco, mas algumas palavras. Então ajudou.

D3 - Ajudou bastante.

D4 - Já tive que ler sim e tudo que eu aprendi na escola me ajudou muito.

D5 - Sim, e quando eu tenho dúvidas eu olho no caderno ou até mesmo no Google.

D6 - O que aprendi na escola muitas coisas.

D7 - Já, eu traduzi no Google. Sim, ajudou.

D8 - Me ajudou na informática, trabalho de escola, pesquisa.

E1 - Algumas vezes me deparei com muitas palavras em inglês e graças aos meus estudos o inglês me ajudou bastante para tradução de algumas palavras.

E2 - sim. O que eu aprendi na escola ajudou muito, mas eu procuro traduzir no Google ou dicionário.

E3 - Sim, algumas palavras eu sei! A escola ajuda bastante.

E4 - Só não ajuda por não ter tempo de estudar em casa pelas tarefas domésticas.

E5 - Sim. Com alguma dificuldade. Em algumas ocasiões, sim, me ajudou.

E6 - Sim, já tive sim que ler algo em inglês, procurei buscar ajuda no tradutor e dicionário e muitas palavras eu já tinha conhecimento em meu caderno, mas confesso que foi difícil.

E7 - Sim. Algumas vezes foi difícil, outras foi tranquilo. Muito, algumas palavras que tive que ler eu já conhecia por ter estudado.

$\mathrm{E} 8$ - (em branco)

E9 - Nada porque eu não uso.

E10 - Sim. Gostaria que tivesse mais aulas. É muito bom traduzir as palavras. 45 anos.

E11 - Sim! Estou conseguindo entender algumas coisas que aprendi com minha profa. Milena._Embora eu tenha dificuldade em algumas coisas.

E12 - Sim. Traduzo de inglês para português.

E13 - Ainda não precisei fazer nenhuma leitura na net, mas sinto que a cada dia tenho progresso no aprendizado dessa língua.

F1 - Já, eu copiei e colei no tradutor. 17 anos.

F2 - (em branco)

F3 - Usei o Google Tradutor e o que eu sabia, fui achando.

F4 - Sim, já tive que ler inglês o que eu aprendi na matéria de inglês me ajudou bastante. 
F5 - Sim, eu usei o Google Tradutor. Ajudou em algumas coisas.

F6 - Um pouco, porque eu ainda tenho muito o que aprender.

F7 - Não por enquanto ainda não.

F8 - Sim. Não tive muita dificuldade pois a escola ajuda bastante.

F9 - Já, nas letras de músicas mas eu procuro achar na legenda, muitas coisas que a prof. ensinou já me ajudaram muitas vezes.

F10 - Não, nunca tive que ler algo na Internet em inglês. Sei muito pouco de inglês e algumas coisas que aprendi na escola me ajudam bastante.

F11 - Não muito, porém o que eu li não foi o básico que aprendemos em sala. Fui até o Google para traduzir

\section{Pergunta 9 - Qual a importância da língua inglesa no mundo de hoje? Qual a importância as língua inglesa para a sua vida?}

A1 - É muito importante, sim.

A2 - A importância serve para quando você viajar para fora do Brasil se comunicar em língua inglesa com as pessoas de outros países.

A3 - Ela é muito importante para você arrumar um emprego melhor. (dona de casa)

A4 - (em branco)

A5 - Hoje a língua inglesa é fundamental para nossa vida principalmente no mercado de trabalho.

A6 - Olha, eu acho que é uma língua muito complicada, não entendo quase nada.

A7 - A língua inglesa já faz parte da nossa vida, mas eu não aprendo.

A8 - É muito importante porque é uma língua universal.

A9 -É muito importante você saber falar muitas línguas, assim você tem muitas oportunidades de trabalho.

A10 - Uma facilidade na comunicação entre pessoas de diferentes culturas. Na minha vida por enquanto nenhuma importância. 18 anos.

B1- Muito importante para que todos possam se comunicar. No momento, nenhuma [importância] mas acredito que futuramente vou precisar.

B2 - Eu acho muito importante que a língua inglesa a gente conhece o mundo.

B3 - No mundo de hoje é um complemento que abre portas de emprego. É importante na minha vida, porque para acessar a internet fica mais fácil quando há um conhecimento.

B4 - Ter conhecimento da cultura inglesa, importância no mercado de trabalho e muito mais.

B5 - Não sei.

B6 - A importância é arrumar um serviço melhor. 
B7 - A língua inglesa é muito importante, ainda mais chegando Copa do Mundo no Brasil

B8 - Intercâmbios, no momento só no âmbito profissional.

B9 - A aprender a se relacionar com pessoas de outros países. 17 anos.

C1 - A língua inglesa faz parte do nosso dia a dia, por isso é importante aprender o inglês.

C2 - No mundo de hoje para trabalhar, para ter conhecimento.

C3 - Nos dias de hoje é importante saber falar pois abre muitas portas de trabalho.

C4 - O inglês é importante.

C5 - A língua inglesa é muito importante para a gente aprender e conseguir um bom emprego no dia de hoje é muito importante. E sempre.

C6 - Eu acho importante pois pretendo fazer um curso de inglês para estar preparada pro mercado quando terminar meus estudos.

C7 - Eu acho que em tudo: a concorrência no mercado de trabalho está grande pois quanto mais qualificação, melhor.

C8 - Hoje é muito importante saber falar inglês. Daqui alguns anos vai precisar muito.

C9 - Muito importante para mim, porque eu pretendo ser uma auxiliar de enfermagem. Quem sabe eu possa trabalhar em alguma casa de alguém que não seja brasileiro, de cuidadora de idosos.

C10 - A importância no mundo de hoje é muito importante, na minha vida está sendo bom o que estou aprendendo, mas reconheço que preciso mais.

C11 - (em branco)

C12 - A língua inglesa é muito importante para a comunicação com todo o mundo.

C13 - (em branco)

C14 - É de grande importância. É um grande sonho da minha vida escrever e ler em inglês, para se comunicar.

C15 - (em branco)

C16 - (em branco)

C17 - (em branco)

C18 - Viajo ia me ajudar muito e poder me comunicar com o inglês.

C19 - (em branco)

C20 - (em branco)

C21 - É muito e importância. Representa muito.

C22 - Para ter conhecimento.

C23 - É muito importante trabalho para viajar para outros países.

C24 - A língua inglesa de hoje é muito importante no mercado de trabalho. 
C25 - (em branco)

C26 - (em branco)

B27 - (em branco)

D1 - A importância é que vários países têm a língua inglesa. Então é muito importante.

D2 - A importância da língua inglesa na minha vida me ajuda muito porque eu trabalho com o público.

D3 - É muito boa. Significa muito para mim na minha profissão muitas coisas são escritas em inglês. [mecânico]

D4 - Sim, você falando inglês ou outras línguas você tem muito mais escolhas no mercado de trabalho.

D5 - A importância é sempre quando você vai procurar um emprego a primeira pergunta é você fala inglês.

D6 - Nossa, é muito importante porque é necessário falar inglês até em entrevista de emprego. Me ajuda no meu serviço. [garçonete]

D7 - A língua inglesa é muito importante para o mercado de trabalho.

E1 - Hoje a língua inglesa é tão importante quanto o português. É uma exigência em muitas áreas de trabalho.

E2 - Saber inglês é bom. Você ler uma frase em inglês e saber o que significa é legal e muito importante no mercado de trabalho.

E3 - De 0 a 1000, 1000!!! Pois a economia mundial gira em torno de um país onde o principal idioma é o inglês. Para a minha vida é muito importante, pois teria muitas oportunidades de emprego. (20 anos)

E4 - No mundo de hoje a língua inglesa no meu ponto de vista é uma variedade de surpresas. Para mim é importante para descobrir coisas novas.

E5 - No mundo de hoje é bastante importante, pois o mercado de trabalho está muito exigente.

E6 - Muito importante pois o inglês hoje já está relacionado em quase tudo, até em mercadorias que compramos, tais quais como roupa, lanches, etc. Para acessar a internet também é muito importante, principalmente para arrumar alguns trabalhos.

E7 - É muito importante hoje precisamos da língua inglesa para quase tudo. É importante para me ajudar a me comunicar.

E8 - Para arrumar um emprego, porque só português não é suficiente. Ainda nenhuma [importância].

E9 - Eu gostaria de aprender, mas não consigo. Sim, é muito importante na fonte de trabalho, ter um grande conhecimento.

E10 - Na vida a gente traz alegria no dia a dia. A importância da língua inglesa para mercado de trabalho.

E11 - Todas! Pois o mercado de trabalho está exigente e quanto mais conhecimento melhor Um dos meus sonhos é conhecer os Estados Unidos, tenho uma amiga que mora lá.

E12 - É muito importante saber inglês principalmente para Copa de 2014 e F1.

E13 - É muito importante pois é o idioma da globalização, e a sua importância para mim é muito boa e lucrativa pois às vezes tenho que ter um intérprete para passar as informações sobre orçamentos.

F1 - É importante para o mercado de trabalho está exigindo muito a língua inglesa. 
F2 - É importante para se comunicar mercado de trabalho e bom para gente alguma coisa e inglês palavras.

F3 - O mundo de hoje não dá para viver sem o inglês porque quando tem eventos não dá para se comunicar.

F4 - Para as pessoas se comunicarem.

F5 - A língua inglesa é muito bom para quem quer viajar para outro país, para poder se comunicar com outras pessoas. Eu aprendo coisas novas e para que eu possa viajar para outro país.

F6 - No mundo de hoje a língua inglesa é muito importante, porque quem sabe o inglês tem mais facilidade para arrumar trabalho.

F7 - É importante para falar, inglês é uma língua muito importante no Brasil.

F8 - Hoje o inglês é indispensável. Na vida também é importante. No trabalho ou até para ter algum contato. Se for preciso saber como se comportar.

F9 - A língua inglesa é importante para que todos consigam se falar porque a língua é universal. Na minha vida, raramente pois só uso quando tem letra de música.

F10 - Hoje em dia, a língua inglesa no mundo é bastante importante porque sabendo falar inglês pode-se arrumar um bom trabalho. Facilita bastante as nossas vidas.

F11 - É muito importante porque hoje em dia a maioria dos trabalhos quer da gente o conhecimento da língua inglesa e para nossas vidas também para conversarmos com pessoas que não falam nossa língua.

Pergunta 10 - Você acha que o que você aprende na escola e na internet podem te ajudar com os objetivos que você apontou na pergunta 2? Por quê? Considere especialmente a língua inglesa.

A1- Sim.

A2 - Porque será uma grande obrigação que eu pretendo cumprir. Considero por ela será muito útil hoje em dia.

A3 - Porque hoje em dia ela está sendo muito usada.

A4 - (em branco)

A5 - Sim, me ajudou bastante porque a língua inglesa é necessária no mercado de trabalho.

A6 - Eu gostaria de saber um pouco mais sobre a internet, mas tenho muita dificuldade sobre o computador. Estou me esforçando.

A7 - [escrita por mim, enquanto A7 ditava] Pode. Cada vez eu venho na escola. O que o professor programa, os alunos preenchem o que o professor pede. Em casa poderia, tem computador, mas por causa das tarefas, falta de interesse, não mexo no computador.

A8 - Sim porque o inglês está em muitas coisas que fazem parte do nosso dia a dia.

A9 - Sim porque abre mais a mente, eu consigo falar as palavras corretamente. Porque na minha idade é só para ocupar meu tempo.

A10 - Sim, na informática me ajuda a divulgar minha empresa.

B1 - Sim, a tecnologia está expandindo e acredito que vou precisar futuramente também.

B2 - Sim 
B3 - Sim, pois esse conhecimento faz parte de todo nosso aprendizado, no ensino médio ou superior.

B4 - Sim e especialmente importante no estudo e no trabalho.

B5 - Me ajuda a me comunicar melhor.

B6 [escrito por mim, enquanto A16 ditava] - Com certeza, porque temos que ter inglês básico para a faculdade. No meu trabalho, por exemplo, na loja de material de construção, um gringo queria um táxi para o hotel [e como nenhum dos funcionários ali presentes conseguiu entender o que o rapaz estrangeiro queria, precisaram chamar o gerente para atendê-lo]. (A16 é vigilante)

B7 - O estudo é fundamental. Aprendendo inglês muito melhor. Para eu conseguir os meus objetivos.

B8 - Sim, com a evolução nos estudos, convivência, dia a dia, terei que interagir.

B9 - Sim, porque o que se aprende na internet muitas dessas coisas são boas para nossa aprendizagem.

$\mathrm{C} 1-\mathrm{Sim}$.

C2 - Sim.

C3 - Sim, acho que vai me ajudar muito pois quero fazer faculdade de gastronomia ou pedagogia.

C4 - Sim, a gente aprende muita coisa.

C5 - Sim, porque é muito importante, a língua inglesa é muito importante, porque ela é mundial é preciso para conseguir um bom emprego no dia de hoje.

C6 - Sim, porque tudo que venho aprendendo é muito importante para mim no futuro pois se eu tiver oportunidade eu gostaria de aprender inglês e outras línguas também porque precisamos.

C7 - Eu acho que sim, pois quanto mais eu aprender melhor será; ainda mais nos dias de hoje que se precisa de estudo até para varrer rua.

C8 - Sim, tem me ajudado bastante.

C9 - Sim, como eu quero ser uma auxiliar de enfermagem para trabalhar em hospitais ou também ser uma cuidadora de idosos mais para a frente fazer uma faculdade para ser uma enfermeira!

C10 - Sim, muito, o Inglês é muito importante e indispensável para uma carreira promissora.

C11 - Sim.

C12 - Sim, o que eu aprendi me ajudou e vai me ajudar mais. O inglês é importante porque quando a gente fala o inglês é fácil de se comunicar com o mundo.

C13 - (em branco)

C14 - Sim, porque com o conhecimento e uma boa qualificação posso seguir uma boa carreira.

C15 - (em branco)

C16 - (em branco)

C17 - (em branco)

C18 - Porque a língua inglesa vai me ajudar muita na minha vida. 
C19 - (em branco)

C20 - (em branco)

C21- (em branco)

C22 - Para ter informações.

C23 - (em branco)

C24 - Ainda não é suficiente o que eu aprendi.

C25 - (em branco)

C26 - (em branco)

D1 - (em branco)

D2 - A língua inglesa é muito importante para nós por causa da Copa em 2014. Vai vir muito gringo para o Brasil.

D3 - Sim, porque o inglês vem mais no Brasil.

D4 - Sim, porque eu preciso.

D5 - Sim, eu também quero viajar para fora e tenho que aprender a falar inglês e até outras línguas.

D6 - O que estou aprendendo na escola está me ajudando muito. Os professores ensinam muito bem.

D7 - Sim, fico mais antenada. Não.

D8 - Pesquisa. O primeiro Triuvirato.

E1 - Sim, pois sei que precisarei muito aprender inglês pois minha profissão exige. Lido muito com o público [atualmente é garçom] e eu, algumas vezes, me deparo com alguém que não fala o português.

E2 - Sim. Pode me ajudar muito no Autocad porque as palavras são em inglês. Eu já estou fazendo um curso de inglês.

E3 - Sim, até porque pretendo fazer um curso de inglês.

E4 - Com muita paciência e dedicação sim, porque eu teria que aprender muito em pouco tempo.

E5 - Sim. Porque a profissão que eu quero exercer não exige muito o inglês.

E6 - Não, eu acho que o que aprendo tanto na escola e tanto na internet é pouco, pois é melhor que todos fizessem um curso de inglês, pois é muito importante e eu admiro muito. Acho uma língua muito bonita.

E7 - Sim. Porque o mercado de trabalho exige muito de nós, que falamos outra língua, que estejamos bem informados sobre tudo.

E8 - Sim. Porque vou ter que saber uma outra língua para me comunicar melhor.

E9 - Sim, preparar para uma vida melhor em todos os sentidos. O inglês é bom para o conhecimento na área da saúde.

E10 - Na escola o inglês eu gosto de aprender. 
E11 - Sim, quando usamos o conhecimento para fins de educação é muito válido e proveitoso.

E12 - Sim, porque me ajuda muito porque o inglês é uma língua de muitos países.

E13 - Quero ser advogado e preciso do idioma para enriquecer minhas possibilidades de clientes, além de abrir portas para novos rumos na minha vida profissional.

F1 - sim, porque eu aprender inglês é muito procurado no mercado de trabalho.

F2 - É importante, tudo que você aprende na escola para ter um futuro melhor, ter um trabalho melhor e inglês é para o mundo todo.

F3 - Na escola aprendo várias coisas que eu posso utilizar nas entrevistas de emprego.

F4 - Sim, pode me ajudar.

F5 - Sim, porque na escola eu aprendo coisas que eu posso usar em uma entrevista de emprego e na internet eu uso para fazer trabalhos de escola e se comunicar com outras pessoas.

F6 - (em branco)

F7 - Sim, para que possa falar inglês com as pessoas, como no serviço, etc.

F8 - Sim. Pois todo o conhecimento é muito importante, é o único bem que ninguém pode nos tirar.

F9 - Aprendo a me comunicar com quase todos e na carreira precisamos saber falar inglês, ou a entender. Se precisar viajar para o exterior, saber falar inglês é muito bom!

F10 - Sim, porque só vou ter um bom futuro se eu estudar, um bom emprego, uma boa faculdade. O que aprendo na escola, no futuro vai me ajudar com meus objetivos. E na internet também aprendo algumas coisas.

F11 - Podem ajudar, sim, pois tudo que aprendemos em sala de aula é muito importante, na internet também. Principalmente a língua inglesa, pois no mínimo temos que ter pelo menos um cursinho de inglês para entrar em uma grande empresa.

Pergunta final - O que você achou dessas perguntas? Se quiser, use o verso desta folha para fazer comentários. (24 respostas)

A2 - Eu achei muito interessante porque tudo isso faz parte da nossa vida hoje.

A8 - Muito boa para conhecer melhor a pessoa.

A9 - Achei muito importante.

A13 - Muito interessante.

A17 - Bem criativas.

B2 - Boa.

B4 - Bom.

B5 - Muito bom. São perguntas muito boas e interessantes para nosso aprendizado. 
$\mathrm{C} 1$ - Achei as perguntas interessantes, gostaria que tivéssemos dessa pesquisa um resultado dos governantes, prefeito, que seja, um avanço melhor no inglês e de preferência mais aulas porque é tão importante quanto a língua portuguesa.

C8 - [No verso, deixou o desenho de um rosto, aparentemente de um personagem.]

C10 - Eu achei muito legal.

D1 - Achei interessante, pois como já falei, o inglês é fundamental nos dias de hoje e através desse trabalho de pesquisa, vocês podem ter mais noção da dificuldade das pessoas em relação ao inglês.

D2 - Eu achei bom, muito importante.

D6 - Bom, eu só não sei o porquê dessas perguntas mas eu gostei muito, é algo que estava guardado dentro de mim e agora estou tendo oportunidade de colocar para fora. E parece pelo meu entendimento que preocupam-se com o nosso futuro.

C8 - Interessantes e precisas, pois é necessário saber o que a gente pensa.

E1- Muito boa.

E11 - Eu acho que é muito importante saber, conhecer e ver o interesse de outros. Eu acredito que quanto mais conhecimento melhor, e nesta questão é muito valido.

E12 - Muito obrigado por tudo.

F7 - Eu achei legal.

F8 - Achei boas.

F9 - Gostei. São perguntas construtivas.

F10-É bom para saber o que o aluno sabe.

F11 - Eu achei importante para saber como a gente se comporta, saber o que a gente deseja no futuro e o que a gente aprende. 
Apêndice 4: Resumo de diário de campo: Aulas Milena

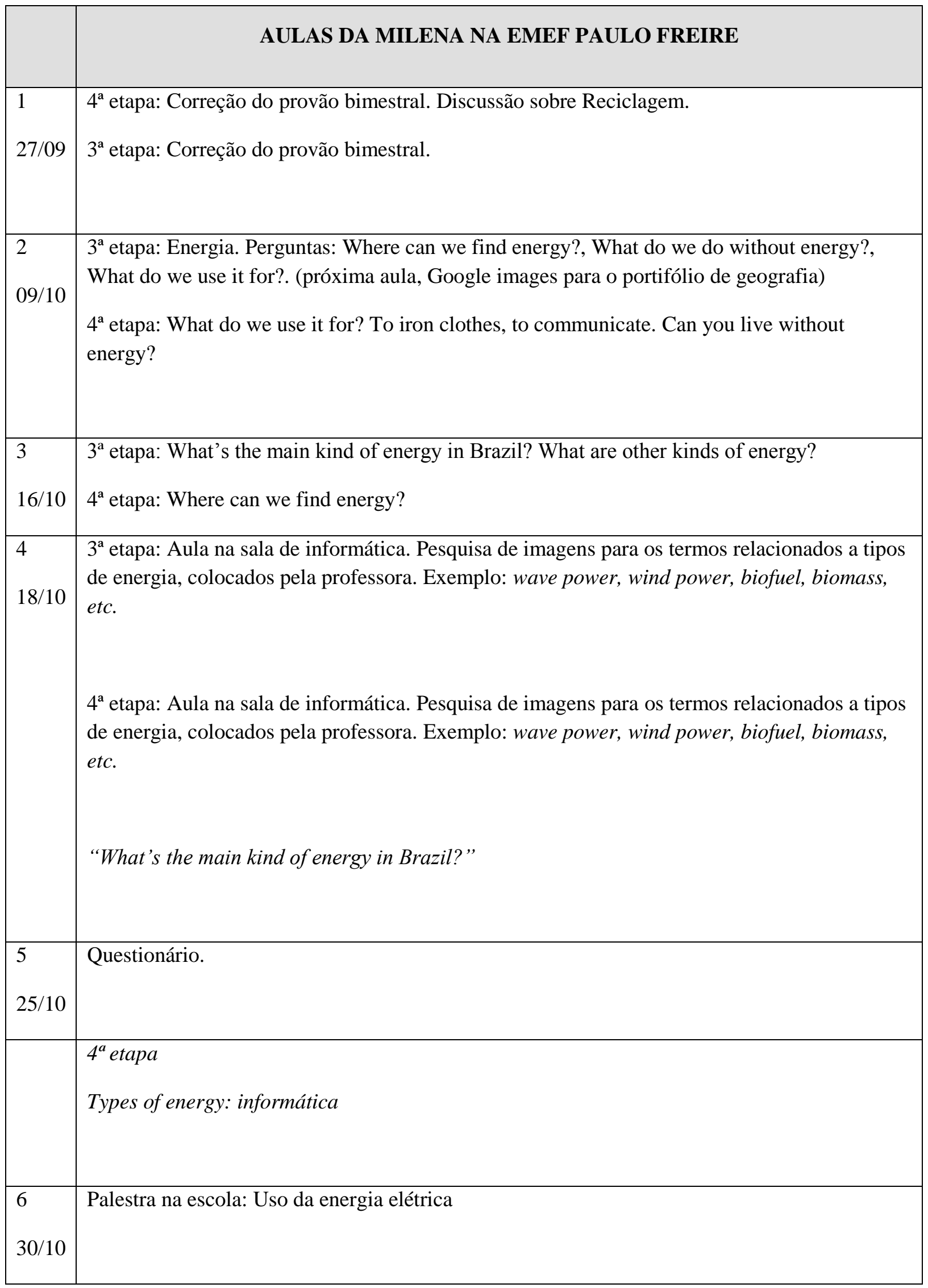




\begin{tabular}{|c|c|}
\hline $\begin{array}{l}8 \\
06 / 11\end{array}$ & $3^{\circ}$ e $4^{\circ}$ Etapa Texto sobre o Halloween \\
\hline $\begin{array}{l}10 \\
08 / 11\end{array}$ & $\begin{array}{l}3^{\mathrm{a}} \text { etapa: The face } \\
4^{\mathrm{a}} \text { etapa: Floor plan }\end{array}$ \\
\hline $\begin{array}{l}11 \\
13 / 11\end{array}$ & $\begin{array}{l}3^{\text {a }} \text { etapa: The body } \\
4^{\text {a }} \text { etapa: Fazer em sala a tarefa que deveria ter sido feita em casa: listar em português } 3 \text { coisas } \\
\text { da casa (nenhum estudante fez em casa). Fizeram em sala e buscaram no dicionário de inglês. }\end{array}$ \\
\hline $\begin{array}{l}12 \\
22 / 11\end{array}$ & $\begin{array}{l}3^{\circ} \text { etapa: Letra de música Strange Fruit } \\
4^{\circ} \text { A (aula trocada) } / 4^{\text {a }} \text { B (duas aulas seguidas): Consciência Negra: Música Strange Fruit }\end{array}$ \\
\hline $\begin{array}{l}13 \\
27 / 11\end{array}$ & $3^{\mathrm{a}}$ e $4^{\mathrm{a}}$ etapa: Atividade avaliativa \\
\hline
\end{tabular}

Apêndice 5: Resumo de diário de campo - Aulas Vívian

\begin{tabular}{|c|c|}
\hline & AULAS DA VÍVIAN NO CENTRO EDUCATIONAL TRANSDISCIPLINAR \\
\hline $\begin{array}{l}1 \\
03 / 10\end{array}$ & $\begin{array}{l}3^{\circ} \text { A: Correção dos exercícios de interpretação de texto informativo, reproduzido no livro } \\
\text { didático. Leitura do texto "Minha infância", do material didático de ciências. }\end{array}$ \\
\hline $10 / 10$ & $\begin{array}{l}3^{\circ} \text { A: Coleta dos brinquedos. Lista de vocabulário sobre brinquedos em inglês (Dia das } \\
\text { crianças: CHILDHOOD, CAR, KIDS, KITE, DOLL, BALL, TOYS, DOLL'S HOUSE). } \\
\text { Exposição dos brinquedos. }\end{array}$ \\
\hline 3 & $3^{\circ}$ A: Revisão de nutritious food e junk food. . \\
\hline $22 / 10$ & Grupo focal com os alunos do $3^{\circ} \mathrm{A}$ \\
\hline
\end{tabular}




\begin{tabular}{|c|c|}
\hline 5 & 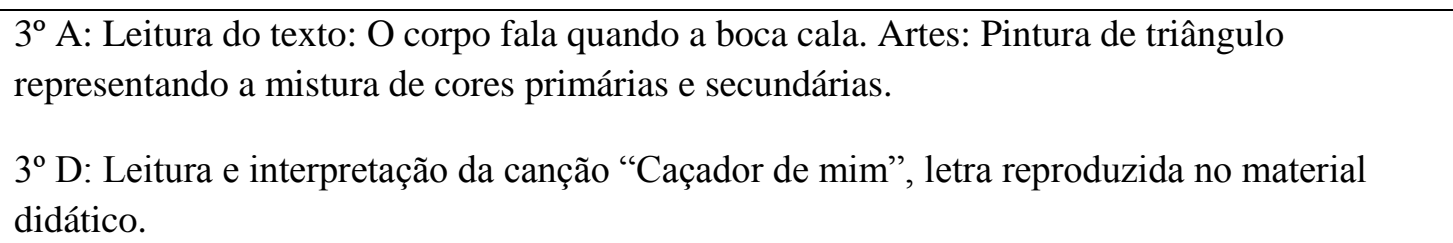 \\
\hline $31 / 10$ & $\begin{array}{l}3^{\circ} \text { A: Where do you live?. Trecho da canção "What a wonderful world". Vocabulário sobre } \\
\text { alimentos } \\
3^{\circ} \mathrm{D} \text { - Professora é hospitalizada. Substituição com trecho de "A Hora da estrela". }\end{array}$ \\
\hline 05/11 & $\begin{array}{l}\text { Correção das questões sobre o texto O Alce e os Lobos. } \\
\text { Estudo dos pronomes e do Verbo To Be nas formas afirmativa e interrogativa. }\end{array}$ \\
\hline $08 / 11$ & $\begin{array}{l}3^{\circ} \mathrm{D} \\
\text { Observação de aula de informática: Word - digitação de texto sobre a Consciência Negra com } \\
\text { utilização de texturas }\end{array}$ \\
\hline $09 / 11$ & $\begin{array}{l}3^{\circ} \mathrm{D} \\
\text { Canção "O Velho do Saco" }\end{array}$ \\
\hline 8 & $\begin{array}{l}3^{\circ} \text { A: Preparo para a prova bimestral. Correção das atividades sobre a fábula "O Alce e os } \\
\text { Lobos" }\end{array}$ \\
\hline $13 / 11$ & $\begin{array}{l}3^{\circ} \text { D: Canção What a wonderful world } \\
3^{\circ} \text { A: Observação de aula de informática: Excel - Fazer o contorno de tabela sobre a } \\
\text { conjugação do verbo "ir". }\end{array}$ \\
\hline $\begin{array}{l}9 \\
21 / 11\end{array}$ & $\begin{array}{l}3^{\circ} \mathrm{A} \text { : Finalização da correção dos exercícios sobre o texto "O alce e os lobos". Denotação e } \\
\text { Conotação. Leitura do texto "Tecendo a manhã". } \\
3^{\circ} \mathrm{D} \\
\text { Preparo para a prova bimestral. Pirâmide alimentar. }\end{array}$ \\
\hline $26 / 11$ & Prova Bimestral \\
\hline
\end{tabular}




\begin{tabular}{|l|l|}
\hline 10 & $3^{\circ} \mathrm{D}$ \\
$04 / 12$ & $\begin{array}{l}\text { Devolutiva da prova bimestral. Atividade de compreensão oral sobre a canção "You are my } \\
\text { Sunshine”. }\end{array}$ \\
\hline 11 & $3^{\circ} \mathrm{A}$ \\
$05 / 12$ & Devolutiva da prova bimestral. \\
\hline 12 & Comentário sobre a prova de inglês, com o $3^{\circ} \mathrm{A}$. \\
\hline
\end{tabular}




\section{Apêndice $6^{49}$ - Entrevista com alunos do $3^{\circ}$ A do Centro Educacional Transdisciplinar em 22 de outubro de 2012}

\section{P: Pesquisadora}

Realizada nos 15 minutos finais da $2^{\mathrm{a}}$ aula.

Contexto: Nesse dia, T tinha faltado, porém por 15 minutos, eu estive na sala dos professores esperando T chegar e revendo as perguntas do questionário, cuja distribuição já tinha sido combinada com T. Eu normalmente esperava por $\mathrm{T}$ na sala dos professores antes do início das aulas, por isso só me dei conta de que T realmente tinha faltado quando um professor, ao entrar na sala dos professores para tirar cópias, me perguntou se o questionário que eu manipulava era para alguma turma, pois ele tinha que dar uma atividade aos alunos de uma professora que havia faltado. Assim, me prontifiquei a ficar com a turma, vendo nisso uma oportunidade de maior tempo para conversar ou até mesmo entrevistar os alunos. Embora eu já conhecesse a sala, fui acompanhada pela auxiliar de corredor, que explicou a situação ao professor de matemática. Com 15 minutos de atraso, eu chego à sala e converso com o professor de matemática à porta. Ele me explica que os 10 alunos presentes em sala já estavam envolvidos em uma tarefa e que por isso não responderiam ao meu questionário de pronto. Isto porque o professor, que estava na sala de frente à nossa (no corredor), ao perceber que a professora $\mathrm{T}$ estava se atrasando, deixou algumas operações de somar números negativos na lousa para que os alunos copiassem no caderno e resolvessem, talvez para mantê-los ocupados até que a professora chegasse.

Julgando não ser adequado interromper a tarefa solicitada pelo professor, esperei que os alunos a terminassem. Auxiliei alguns alunos e, ao final, deixei o gabarito na lousa para que conferissem suas respostas. Isso levou cerca de 30 minutos.

Por volta das $8 \mathrm{~h}$, eu expliquei o objetivo do questionário, me apresentando novamente aos alunos, apesar de já me conhecerem como uma "teacher" que estava há três semanas observando suas aulas. Essa era minha quarta visita à turma.

Conforme minha previsão, os alunos levaram cerca de meia hora para responder ao questionário. Durante essa tarefa, alguns alunos pediram esclarecimentos sobre algumas perguntas. Aproveitando o número reduzido de alunos em sala, pude perceber respostas em branco e verificar o que isso significava. A aluna A10 não tinha entendido três das dez perguntas e ia entregá-las em branco, mas ao tirar as dúvidas e me contar o que queria escrever, respondeu-as com tranquilidade. A aluna $\mathrm{A} 3$, sentada à minha frente, entregaria sem a última pergunta em branco: eu, sentindo que talvez ela se sentisse mais confortável falando do que escrevendo, perguntei a ela e anotei a reposta.

Vendo que teríamos pelo menos 15 minutos restantes, sem um planejamento prévio, embora desejasse convidálos para tal mais adiante depois de refinar melhor o olhar, decidi fazer um "grupo focal": uma entrevista coletiva em que todos pudessem esclarecer, comentar ou acrescentar informações relevantes e mais espontâneas às minhas indagações. Senti essa necessidade também por conta da dificuldade que eles tiveram para responder ao questionário e das limitações do meio escrito.

A entrevista coletiva está transcrita a seguir:

P: Eu poderia pedir para a gente fazer um círculo? A gente tem mais dez, quinze minutos até o fim da aula... Eu só queria fazer uma rodada de perguntas... Num círculo... Podia ser só com as cadeiras para não tomar muito tempo para arrumar.

[Os alunos concordam e começam a arrumar as cadeiras para fazer o círculo]

$\mathrm{P}$ : O círculo é para a gente ficar à vontade, para a gente se olhar... [cantando] "Olhos nos olhos [todos dão risada]..., quero ver o que você me diz"...ok?

[alunos acomodam as cadeiras]

A1: Eu tenho que entrar na roda agora também? [A1 era o único aluno que não tinha terminado de responder o questionário]

P: Fique à vontade para terminar, quando você terminar, aí, você vira a cadeira.

A1: Então está bom, estou terminando já.

$8: 31$

[Já sentada numa cadeira, no círculo com os alunos]

P: Bom...

[A2 começa a comer uma maçã e me oferece um pedaço]

${ }^{49}$ As entrevistas transcritas estão organizadas em ordem cronológica. 
P: Obrigada, muito obrigada... Eu já vou comer alguma coisa também... Só para vocês saberem um pouco mais da minha pesquisa. Eu sou professora de Inglês, como vocês devem se lembrar, eu já tinha explicado para vocês algumas aulas atrás, né... E minha pesquisa, inclusive eu estou aprendendo muito, é sobre inglês e novas tecnologias. Isso é informação nova pra vocês, né.... Então, eu gostaria inclusive de ver vocês usando o laboratório de informática também, além das aulas de inglês e dessa conversa e dos questionários.

A3: É na terça, viu professora.

P: Terça, né. Já fiquei sabendo, muito legal. Então, eu gostaria de saber que ficou também. Que às vezes só com um questionário é uma coisa muito... talvez difícil de saber... de vocês colocarem no papel. Tem vários jeitos pra coletar informação. Pode ser por escrito, como vocês viram aqui no questionário, que é uma coisa um pouco limitada às vezes. Pode ser também falando. Eu acho que vocês são mais espontâneos...

A4: Falando.

P: Falando, e um jeito de a gente se comunicar inicialmente é falando, né... Então, será que vocês não gostariam de me contar mais alguma coisa ou alguma outra coisa que vocês queriam contar sobre essas minhas perguntas? Se vocês quiserem, eu devolvo o questionário para vocês olharem de novo. Tem alguma pergunta que vocês gostariam de comentar? De deixar mais claro?

[Nenhum aluno demonstrou interesse em olhar o questionário - talvez porque eu continuei falando]

A2: Sobre isso tudo, né, que você perguntou.

P: Sobre isso tudo que eu perguntei.

A2: $\mathrm{Eu}$, foi com muita dificuldade assim, a gente morava no interior, né... E nosso pai não aceitava mulher estudar e saber mais do que o filho homem. Então eu não tive oportunidade, mas eu lembro que eu era apaixonada por leitura, pela escola, eu queria ser uma professora... Mas infelizmente, não deu, não foi possível. E agora comecei a estudar e estou amando, jamais vou sair da escola... Até eu ficar velhinha eu vou ficar estudando. Não vou parar mesmo.

P: Que legal, A2. Mais alguém teve essa dificuldade de não ter podido estudar antes e agora está valorizando...

A5: Eu morava no sítio até na cidade era pertinho da escola. Só que tinha muito mato, tinha onça...

P: Era longe?

A5: Não, era até perto. Mas tinha mato tudo em volta, tinha onça então a gente não podia sair.

P: Aham...

A5: Então eu não fui para a escola. É o segundo ano que eu estou estudando aqui, também é o segundo ano que eu estou numa escola.

A6: Eu também, o mesmo esquema delas, né. Os pais não deixavam a gente estudar porque não podia saber mais que os filhos homens.

P: Só homens? Vocês têm irmãos homens que estudaram?

A6: Estudaram.

P: E que profissão que eles têm hoje?

A6: Tem um que é engenheiro... Eu tenho um irmão engenheiro.

$\mathrm{P}$ : Interessante, ele tem a mesma idade que a senhora?

A6: Não, mas ele estudou, foi a fundo.

P: Mas na mesma época ou teve essa mesma trajetória, estudou depois?

A6: Não, não, ele estudou até a $4^{\text {a }}$ série lá no interior, que a $4^{\mathrm{a}}$ série de lá seria o ginásio de hoje. Ele fez o segundo grau de hoje que ele fez a $4^{\mathrm{a}}$ série. Depois esqueceu, começou a trabalhar, estudou bastante e se formou, hoje ele é formado. E eu não tive essa oportunidade. Também, casei cedo feito uma tonta...

[Alunos dão risada]

A6: Né... Aí, vai cuidar do filho. Depois, foi que eu vim pra São Paulo [a aluna nasceu em Bezerros - PE], fui cuidar de filho, não dá tempo de trabalhar e estudar. Ou você trabalha ou você cuida dos filhos. E quando eu vim pra São Paulo, eu fui separei, eu tinha que cuidar dos meus filhos, não tinha que estudar. Mas aí, eu sempre fui uma pessoa aplicada, mesmo sem os estudos... Sempre fui aquela pessoa aplicada, eu aprendi a fazer as coisas... Ia na escola de artesanato, na escola de culinária, onde tivesse, mesmo sem saber ler, né.

P: Mesmo sem saber ler?

A6: E hoje eu moro aqui, eu sou líder comunitária do bairro, gosto muito do que eu faço, tenho um trabalho excelente com o pessoal, apesar do trabalho que dá, é um trabalho excelente, eu cuido de cento e sessenta famílias do bairro, né, aonde eu vou buscar as coisas pra eles, eu busco. Eu peço pra mim, peço pra eles, corro aqui, corro acolá, ajudo, eu tenho um trabalho excelente onde eu trabalho. Excelente, eu gosto. Eu adoro meu trabalho. Entrei na escola há oito anos atrás, aí comecei a estudar, aí minha filha me largou cinco filhos no mundo e sumiu. Parei então pra cuidar de neto. E hoje já tão mocinhas, rapaz, menininho. Aí, parei de estudar. Há dois anos atrás, eu vim fazer uma festa aqui num dia, na semana do Natal e a diretora falou assim, "Eu lhe conheço de algum lugar?". Eu falei, "Eu já estudei aqui" "Por que que parou?". Aí comecei a explicar para ela, né. Ela falou, "Vou fazer sua matrícula e a senhora vai voltar". Aí voltei, fiquei, já estou há dois anos aqui. E 
estou adorando, estou amando, sei que estou aprendendo alguma coisa, estou crescendo. Porque a gente tem que buscar também crescer, não tem só que aprender a ler e a escrever as letrinhas, a gente tem que crescer na vida. P: Sim, na vida.

A6: É, e hoje eu trabalho num buffet que é meu. Eu tenho um trabalho bom, né. Tenho um trabalho excelente. Tenho meu buffet que eu trabalho, é difícil um fim de semana que eu não tenho festa, festinha infantil... De vez em quando faço uns bolinhos pras meninas aqui... As meninas já conhecem o sabor do bolo ruim [rindo], mas eu faço. E estamos aí, eu estou aí.

P: Como vocês acham que a possibilidade de ler e escrever e aprender o que vocês aprendem aqui na escola faz vocês crescerem na vida, usando um termo que vocês falaram bastante hoje.

A9: Em todos os sentidos. Só de você sair de casa já se torna assim você mais social... você ficar dentro de casa, só raspando panela, lavando roupa, só limpando casa e não pára, todo dia para fazer. Você fica uma pessoa meia, meia, meia assim...Lfazendo gesto com as mãos espalmadas ao lado dos olhos, como o cabresto de um animal, sinalizando as limitações de perspectiva]... Você saindo, você aprende coisas, pelo menos para mim, eu não sei os outros...

P: Para os homens é igual essa questão de cuidar da casa?

A1: A gente ajuda a mulher... Ás vezes a gente ajuda assim, quando ela vai trabalhar. Então se eu não tenho nada para fazer, eu faço comida.

P: E a escola tem ajudado a mudar a visão sobre a vida?

A1: Ter mais conhecimentos, né. Então para mim está sendo muito bom.

P: E você está na EJA por quê?

A1: Por falta de oportunidade, de trabalho, entendeu... A pessoa tem que trabalhar, e sem estudo hoje não tem como. Nem no primeiro grau não consegue serviço registrado. Pelo jeito é difícil. Eu trabalho por conta, sempre trabalhei por conta, mas quanto mais conhecimento para mim, melhor.

P: E você, A8?

A8: Para mim é um pouco para a carreira que está exigindo. Então eu preciso pegar o diploma para conseguir. E estou aprendendo muito.

P: Sim. Quantos anos você tem? [A8 é o aluno mais novo da turma]

A8: 18.

P: Por que você parou de estudar?

A8: Por problemas de saúde desde criança, eu não tinha condições de estar indo para uma escola.

P: Uma escola regular?

A8: Então, assim, eu acabava faltando muito. Vivia indo no hospital, fazendo exames, tudo... Aí acabava repetindo de ano por falta, porque não estudava para as provas.

P: Mas um problema de saúde mesmo ou você acha que a escola regular de alguma forma excluiu você?

A8: Não, sempre estudei, sim, sempre gostei.

P: Você gostava da escola?

A8: Eu estudava em escola particular, sempre.

P: Ah, não foi em escola pública que você estudou?

A8: Não, eu estudei em escola pública dois anos, mas também não consegui terminar justamente por causa disso.

Aí agora eu estou conseguindo, estou melhor, graças a Deus. Agora estou correndo atrás do prejuízo, né.

P: Ok, que bom... A7? E como é a sua história em relação à escola e aos estudos?

A7: Minha história também, eu parei de estudar para vir para São Paulo.

P: Você é de onde?

A7: Eu sou da Bahia. Aí, cheguei aqui, tinha que trabalhar. Ou trabalhava, ou estudava, um dos dois. Aí, como eu não tinha condições de estudar ao mesmo tempo, aí eu fui trabalhar. Mas aí agora eu mudei e arrumei um trabalho pra estudar com escola, mas só que aí eu arrumei trabalho para noite. Aí então eu sumi de casa.

P: Pro CENTRO EDUCACIONAL TRANDISCIPLINAR. Por que você escolheu o CENTRO EDUCACIONAL TRANDISCIPLINAR?

A7: Porque para mim é vantagem e porque de manhã é melhor que à noite. Eu trabalho à noite.

P: Qual a sua profissão?

A7: Minha profissão é ajudante.

P: Aí você estudando você consegue melhorar sua posição nesta profissão ou você quer mudar de profissão? Qual é o objetivo?

A7: Eu quero melhorar minha vida. Então eu estudo para também ser alguém na vida.

P: Perfeito. Mais alguém que não falou nada até agora, que ficou quietinho?

A10: Eu.

A1: A10.

[Alguns alunos dão risada]

A10: Na minha infância eu estudei, eu fiz até a $4^{\mathrm{a}}$ série. Depois eu mudei para São Paulo. 
P: Então você pegou uma escola diferente do que existe hoje...

A10: Então eu mudei para São Paulo em [19]75...

P: De onde que você é?

A10: Interior de São Paulo.

P: Que cidade?

A10: Bilac.

P: Não conheço, vou pesquisar sobre sua cidade.

A10: Então, quando eu vim aqui eu me arrependo de não ter estudado.

P: Por que não estudou?

A10: Porque... por falta de interesse, porque eu não gostava de estudar. Eu não gostava, era obrigada, odiava... Então eu vim aqui, eu vim a estudar já tem quanto... faz três anos. Podia ter estudado, tive só uma filha... Trabalhei, quando ela tinha 7 anos é que eu fui começar a trabalhar. Podia ter estudado. E eu não estudei. Isso não vinha na minha cabeça. Não sei como é agora eu estou na escola e gostando muito. Podia ter feito tudo já, há muito tempo mas eu não tinha como. Escola pra mim não existia mais...

P: Por que a senhora voltou agora?

A10: Porque eu ia ficar sem fazer nada, sem trabalho...

P: A filha saiu de casa?

A10: Agora ela mora na Vila Mariana, mas ela passa o fim de semana na minha casa. É só eu e meu marido, não tem muita coisa para fazer dentro de casa. Vou fazer o quê? Precisa fazer alguma coisa. Trabalhar eu não vou trabalhar. Então tem que fazer alguma coisa para passar o tempo, gente.

P: Qual era a sua profissão?

A10: Minha profissão, eu trabalhava num escritório.

P: Fazendo o quê? Administração?

A10: Isso.

P: Papéis e documentos, contas...

A10: Isso mesmo, numa loja de ferramentas.

P: Mas sabia ler e escrever porque a senhora já tinha estudado.

A10: Sim, sim, sim. Eu só trabalhei em escritório, muitos anos de trabalho em escritório.

P: Bem interessante essa história... Alguém mais gostaria de contar a sua história?

A6: Eu tenho, professora, assim que a gente aprende, com essa convivência. A gente aprende a conviver. A gente aprende a ser mais sociável. Porque a maneira como eu criei os meus filhos e a maneira como eu criei meus netos é outra. A gente olha pra frente. Se a gente cresce, a gente tem outro tipo de ver, outro tipo de visão. E as amizades, faz a gente ser diferente. Quanta gente que eu conheço ???

P: Inclusive foi por um convite que a senhora voltou pro Centro Educacional Trandisciplinar.

A6: Com um convite da outra diretora. Eu encontrei a Sara em outra escola. E ela sempre foi uma pessoa maravilhosa. De enxergar lá na frente. A gente é amiga.

P: Deixa eu perguntar uma última coisa, que eu acho que já estou tomando o tempo da próxima aula. Só para terminar, pessoal. As tecnologias digitais, internet principalmente, qual é a importância delas no mundo e na vida de vocês?

A9: É muito necessário. Eu tenho uma vontade grande de operar um caixa, de bater lá um dinheiro... É muito importante. Eu tento, mas é meio complicado, viu. Eu tenho um computador para mim é um bicho de sete cabeças.

P: Quem aqui tem computador?

[7 alunos têm computador]

A1: Eu tenho um computador há dois anos, mas só peguei nele uma vez.

[todos começam a falar ao mesmo tempo, brincando com o A1]

A6: Professora, eu até um mês atrás eu estava fechada pra esse negócio de computador. Comprei um computador. Mas essa semana eu tenho me saído assim uma maravilha. Ontem eu peguei um .... que eu tinha que fazer. Estou aprendendo a pesquisar, a buscar no computador.

P: Legal, A6. Deixa eu contar uma coisa pra vocês antes de eu ir mesmo. Eu me formei no Ensino Médio em 2001. Então, vocês podem calcular aí minha idade [risos]. Eu não tive aula de informática na minha formação escolar, porque, nas escolas estaduais, naquela época, não existia. Hoje, vocês têm até uma disciplina que se dedica a informática aqui na escola. Por que vocês acham que isso acontece?

A3: Por falta de interesse, assim?

P: Você diz que a escola não tinha interesse em ensinar informática para os estudantes?

A6: Não, não acho.

P: Mas pode ser. Ou alguma coisa aconteceu por aí no mundo?

A9: Evoluiu.

A6: Evoluiu, né, professora?

P: Evoluiu? Como assim? 
A6: Evoluiu bastante para melhor, para que a gente aprenda, né.

A9: A tecnologia, né.

A2: Para que a gente busque. Hoje em dia só não aprende quem não quer.

P: A senhora tem razão. E como vocês enxergam vocês mesmos pensando nessa fala que a A2 disse?

[4 segundos sem resposta]

P: Uau, que silêncio!

[risos]

P: É... Pensem com mais calma, então. Acho que vou pedir pra professora deixar mais uma vez essa conversa. Acho que assim vocês ficam mais à vontade do que com o questionário, né.

A1: A gente fica meio tímido.

A6: Eu estou me sentindo alguém. [?]

A2: Professora, eu evoluí bastante. Eu acho, entendeu.

P: Com a internet, com a escola, com o quê?

A2: Em tudo, com tudo!

P: É lógico que aprender não é só na escola, né. A escola é importante...

A2: [A escola] é um incentivo, né.

A6: [A escola] é um complemento para a vida da gente. Daquilo que a gente aprende com aquilo que a gente já tem. É um complemento, a escola. A escola não é tudo. A gente tem que vir para a escola para a gente ter aquilo a mais.

P: Tem que ter a ponte. Na minha época de escola, por exemplo. Em 12 anos, teve muitas mudanças pra melhor e pra pior. Uma delas que a gente tem que reconhecer é que a escola abriu muito mais o olhar pro mundo.

A2: Com certeza.

P: Um deles é colocar o uso de informática. Na minha época não tinha aula de informática.

A5: É verdade.

P: A informática existe desde a década de 1950. Internet, desde a década de 1970. Pros usuários comuns, sem ser de laboratórios, empresas, mas nas suas casas, pelo menos desde a década de 1990. Se eu me formei em 2001, quer dizer que eu passei uma década sem acesso a isso dentro da escola. É lógico que a sociedade também talvez não reconhecesse a importância desse desenvolvimento tecnológico pra educação, porém, hoje isso tem mudado. Bem, já estou falando demais. Obrigada a todos vocês por essa conversa. Foram valiosíssimas falas e contribuições. Espero depois continuar conversando um pouco mais. 


\section{Apêndice 7: Entrevista com professora Milena em 25 de outubro de 2012}

P: Assim também?

$\mathrm{P}:$ E aí você teve que transcrever?

P: Qual que era o objetivo?

M: Então não, não era para inglês, era para meu trabalho eu tenho aínda, ficou muito bom, eu gostei tanto do meu trabalho. É... era olhar crítico sobre crítica literária

P: Ah, que legal.

M:Aí eu peguei, porque estava, assim, começou porque eu fui fazer pesquisa sobre alguma coisa, e eu não gostei sabe..., era muito assim..., a porque se o crítico fulano falou, não importa se ele falou besteira , como ele é critico literário ele pode falar o que ele quiser, e aquilo começou a me incomodar, era uma coisa que eu sentia, sentia assim que eu entrei na faculdade. Nem sempre porque o cara tem o conhecimento ele vai falar a coisa mais acertada sobre determinado autor, determinada obra. Aí eu comecei a investigar o que se tinha escrito sobre isso, a crítica da crítica, entrevistei alguns professores, né, e eu gostei muito do resultado tudo, eu lembro que a Eliana incentivou bastante, era um trabalho de Comunicação Escrita 3 eu acho, e tipo deu trinta páginas, não era para dar tudo isso, eu me empolguei muito, com citações, entrevistei alunos também, nossa, eu gostei muito de ter feito.

P: Legal, hein! Foi em português ou foi em inglês?

M:Foi em inglês.

P: Tá, mas a entrevista que você fez foi em português?

M:Foi em português.

P: Entendi. O objetivo era passar tudo isso para o inglês as ideias?

M:Isso, isso.

P: Mas que assunto, né!

M:Gostei muito.

P: Muito bacana.

P: Aí você colocou os seus interesses investigativos. Então tá, eu vou fazer aquela primeira pergunta básica que é um pouco sobre a sua formação que eu gostaria de saber né, conheço um pouco né, da USP, e a sua decisão em lecionar em escola pública?

M: Certo, pode começar?

P: Pode

M: Bom, eu sempre estudei em escola particular, escola de bairro. Fiz USP, fiz 5 anos, bacharelado e licenciatura, português e Inglês. Durante o período da graduação eu fiz iniciação científica, na área de literatura Brasileira. Depois que eu me formei eu.... então, essa decisão por escola pública foi meio que um..., não diria um acidente de percurso, mas foi uma coisa meio por acaso. Em 2009, que foi o meu último ano da faculdade, ia ter concurso público, estava todo mundo, eu e meus amigos íamos nos formar, a gente queria ver como é que era, como era uma prova tal. Então, a gente fez [a prova de seleção] muito mais para ver como seria do que "Ah! Eu vou trabalhar em escola pública". Mas é claro que essa ideia de estabilidade que a gente sempre havia ouvido falar era uma coisa bastante atrativa. E aí fomos, nós prestamos, e num grupo de 5 pessoas os 5 passaram. E eu sou a única que realmente escolheu e foi atrás. Uma amiga minha depois prestou e continuou, tal.

P: Desses cinco amigos que você falou, eles continuam hoje também ou só fizeram a prova?

M: Eles passaram, assumiram, largaram depois. Uma amiga minha prestou depois, passou, tem 2 cargos na prefeitura, é uma excelente professora de inglês também, inglês e português. A gente conversa muito sobre isso porque acho que a gente tem que ter as coisas muito certas, o que você quer.

P: Trocar experiências também.

M: Enquanto isso, eu tirei um ano mais livre em 2011 e fiz uma pós-graduação em Docência no Ensino Superior, porque o meu plano a médio prazo é dar aula em faculdade. Pode ser aula de língua inglesa, de língua portuguesa, de literatura né, eu acho mais aberto, mais flexível do que eu vejo a minha situação agora, em termos do que lecionar. Me formei, foi legal, uma experiência interessante. Conheci um pouco sobre a realidade do ensino superior, e em maio de 2012 agora eu comecei um curso pela Universidade XXX, uma pós-graduação que se chama Ensino de Língua Inglesa e Uso de Novas Tecnologias. É apaixonante, eu estou gostando muito, eu me sinto motivada, inspirada. Teve uma primeira parte do curso, gramática assim, muito complexa, bem aprofundado mesmo, coisa que eu nunca tinha reparado na língua inglesa. No nosso último encontro começamos essa parte das metodologias, abordagem comunicativa, e eu, na época da faculdade, eu não me dediquei tanto a isso como eu poderia, até tinha comentado isso com você.

P: Você estava com outro foco!

M: Meu foco era outro, e eu estou amando de paixão, os professores são excelentes. Já tem grupo no Facebook, a gente está trocando figurinha, e blog, site, não sei o que. Já fiz umas coisinhas de frescurinha ao longo dessa semana, então está muito legal. Formação basicamente é isso. 
P: Então já vou fazer a última pergunta. Como você se relaciona com as tecnologias digitais, e por que você escolheu fazer esse curso de pós- graduação? Tem a ver?

M: Tem, tem a ver, primeiro porque eu queria na parte do inglês uma coisa assim mais específica, e porque o que eu mais vejo é que a tecnologia é uma ferramenta que está aí. A gente tem que se apropriar dela. Eu acho que não é a solução para os problemas da educação como um todo como muita gente pensa, muitas escolas pensam. Mas acho que é uma ferramenta fantástica, que pode abrir novos horizontes para os alunos, aproximar os professores dos alunos também. A gente está perto desse mundo deles. Em 2009 eu fiz um treinamento pela $\mathrm{XXX}$, e eu fiz um curso para usar lousa digital, eu achei muito interessante. Eu falei, "Poxa, se isso aqui tivesse nas escolas assim, era uma ferramenta a mais, era um atrativo a mais".

P: Você foi professora na XXX?

M: Não, eu participei do treinamento deles, eles me chamaram depois, só que eles precisavam de uma disponibilidade que eu não tinha porque eu tinha entrado na prefeitura.

P: Ah sim, então você optou mesmo, fez uma escolha?

M: Exatamente.

P: Mas eu não entendi essa questão da lousa digital ser um atrativo!

$\mathrm{M}$ : Eu acho interessante, porque a princípio essas coisas me causam um certo constrangimento, desconforto, porque é novo, porque eu não sei usar. Mas eu não posso simplesmente fingir que não existe, falar não quero saber, eu vou evitar o quanto eu puder. Não. O que eu puder usar, eu vou usar. Então, enquanto a gente estava lá, parte do treinamento da XXX era aprender a usar a lousa digital, a lousa deles. Eu seu que existem variações, mas não devem ser muito diferentes. Então é uma coisa que eu achei muito legal, eu tenho certeza que todos gostariam. Nós compramos uma que está aqui inclusive né, eu não sei exatamente onde ela vai ser instalada porque não dá para ficar móvel, não dá para ser uma lousa móvel já que nós temos aqui dois andares. O que eu uso em sala de aula é muito pouco, perto do eu poderia usar, porque existem outras coisas a serem administradas, e eu também me acostumar com a ideia de estar sempre com o equipamento. Eu levo o que, o projetor, às vezes eu uso o Powerpoint nas aulas, rádio sempre que dá. Eu acho que poderia fazer muito mais parte do meu dia a dia, mas no momento é o que dá pra fazer.

P: Você disse que tem outras condições que te motivam ou que te impedem?

M:É porque eu sinto uma coisa que eu acho negativa como professora. Isso não sou só eu. Nós temos que administrar uma série de outras coisas, que não o conteúdo. ou a conversa com o aluno, o class management, o group management. Então, você de repente ter que parar a sua aula pra chamar a atenção do aluno que está fazendo isso, isso, isso. Nós temos aqui casos de alunos que promovem vandalismo, então a gente fica meio receoso mesmo de, de repente, perder alguma coisa, equipamento, enfim...

P: Então é uma preocupação sua?

M:Sim.

P: Para a segunda pergunta, como você vê o ensino de inglês e tecnologias digitais no contexto global, ou seja, na sociedade globalizada, em rede, capitalismo veloz?

M:Especificamente no ensino?

P: No ensino de inglês e novas tecnologias.

M:Olha, eu sei que existem cursos a distância, eu conheço blogs muito bons de inglês, eu não conheço nenhum assim que, eu sei que existem blogs para cursos de inglês, o English Town, por exemplo. Mas eu uso muito mais para pegar material de aula. Eu acho que existe um risco que se tem, não só com inglês, mas com o conhecimento em geral. A gente confunde muito conhecimento com informação. Eu vejo um monte de site, um monte de blog na internet com cursos para fazer. E eu acho que tudo aquilo me basta simplesmente por estar lá. A gente tem que ter um filtro, a gente que eu digo assim, o professor, o profissional, o aluno quando vai pesquisar, não é simplesmente pegar da Wikipédia, existem outros caminhos, outros sites, outros lugares para você consultar, e a partir daquela informação você construir o seu conhecimento, que seja relevante para você. Porque senão você tem tudo e não tem nada ao mesmo tempo, você não sabe filtrar, você não sabe selecionar, será que esse site tem credibilidade, será que isso aqui é de verdade? As pessoas tomam como princípio que tudo aquilo é real, e não é.

P: Está certo, e como que você, você tem algum olhar crítico, justamente como você mencionou, a diferença entre informação e conhecimento, mas assim, nessa questão da globalização mesmo né, da língua inglesa de alguma forma se impor, as próprias tecnologias estarem se impondo também no nosso dia a dia.

M:Nós não sabemos como usar. Por exemplo, eu estava comentando com uma amiga minha, não tem nem muito a ver com educação, mas as pessoas não sabem usar Facebook, expõem coisas muito pessoais, depois não sabem como lidar com situações embaraçosas por conta daquilo, não sabem usar. O Twitter pode ser uma ferramenta muito legal de interação, mas "Ah, estou indo para o banho". Não, isso não é relevante. Nós ainda, apesar de ter muitas coisas incríveis sendo criadas, nós ainda estamos engatinhando no sentido de saber usar.

P: Eu vejo isso como uma confusão entre o que é íntimo e o que é público. 
M:Exatamente, não se tem mais uma fronteira, as pessoas se expõem muito, elas não tem uma noção de como é perigoso, de como é desnecessário. Poderiam entrar na internet para fazer uma coisa muito mais produtiva, eu imagino.

P: Por exemplo aprender sobre o mundo?

M:Exatamente.

P: E como você vê essa necessidade de aprender inglês e tecnologias digitais na EJA e nesse contexto, dessa escola, nas suas aulas, com seus alunos?

M:Bom, é o seguinte, eu não tenho grandes pretensões com inglês na EJA. Não que eles não sejam capazes, mas eles vêm, por mais que eles tenham escolaridade, eles têm uma certa defasagem. Eu sempre faço planejamento pensando na minha sala, e naturalmente esse planejamento vai mudando ao longo do ano, porque eu vou vendo até onde eu consigo ir, qual é o limite dos meus alunos, o que dá para fazer e o que não dá. Às vezes, eles me surpreendem, o que é muito bom, aí eu vou adiante. Eu aproveito tudo o que eu recebo deles, todo o retorno que eles me dão. Então para mim EJA é sempre lucro, porque normalmente eles estão muito dispostos a aprender. Por mais que normalmente eles tenham receio, eles sabem que eles precisam aprender, eles escolheram estar aqui. Na maioria, esse é o caso, eles escolheram estar aqui. Do mesmo modo que o inglês, eu procuro dar uma base, e procuro mostrar para eles como o inglês é importante no mundo, e como muitas vezes faz parte da vida deles e eles não sabem.

P: Você tenta associar o local com o global sempre?

M:Sempre, sempre. Eu sempre comparo muito português com inglês. Às vezes eu pego uma palavra em inglês com significados bem diferentes, aí os alunos falam que é difícil, aí eu digo que não, que no português nós temos a palavra manga, que pode ser uma parte da roupa ou uma fruta. No contexto certo você sabe exatamente o que eu estou falando. Então eu faço muita ponte entre o português e o inglês, porque além disso eles começam a pensar sobre o português, que é uma coisa que normalmente eles não fazem, não sabem sobre o própria língua, como ela é complexa. E aí, de repente eles pensam que inglês não é tão estranho, não é tão diferente do português. Então é assim, familiarizar eles com o inglês, mostrar que faz parte do mundo deles, que não é um bicho de sete cabeças, que é acessível, que é possível. A mesma coisa com a informática. É que eu tenho menos familiaridade de trabalhar informática com eles. Eu me sinto muito mais confortável, bem na minha zona de conforto com o inglês. Mas se der para levar, eu levo, até para eles verem que informática de repente não é um bicho de sete cabeças, é uma questão de você se acostumar, é uma ferramenta para você se apropriar, e não é só para o inglês, é para a vida. Ainda que eles não vão usar, é para saber que existe. É um conhecimento muito bom pra eles, porque nem sempre EJA está se escolarizando por causa de emprego.

P: Você sente que os alunos estão mais preocupados em aprender, eles estão aqui por que motivo?

M:Olha, eu não consigo colocar em números. Tem uma parte dos alunos que estão aqui porque a empresa está pedindo, porque o patrão está pedindo, porque precisa terminar os estudos para fazer um concurso público. Só que você deve ter reparado na sala de aula que tem muita gente na casa dos 60 anos...

P: E por que essas pessoas estão aqui?

M:Porque o ser humano está sempre buscando, a escola é tudo, a escola é o social, é você se comunicar, é você se expor, trocar ideia, é você crescer. Porque se fosse conteúdo pelo conteúdo, eles estudavam em casa com o livro, mas é a troca entre os seres humanos de experiências de vida, experiências riquíssimas. Eu acho que é isso também. É esse olhar que a gente tem que ter quando a gente está com EJA. Eu escuto cada história. Eles têm muito mais experiência de vida do que eu. Às vezes eu fico até meio assim, com medo de falar alguma coisa minha porque eu não sei nada. Eu posso saber muito de inglês, mas em termos de vida eu não sei nada. Às vezes você conversa com eles e fala "Nossa!!!"

P: Então você mesma fica impressionada com a troca?

M:Sim.

P: É sua aprendizagem também?

M:Sim, todo dia, toda aula.

P: Como você vê a relação identitária dos alunos considerando as suas abordagens nas aulas?

M:Eu não me preocupo muito com o currículo, tá, por exemplo, nós recebemos no ano passado um livro bem legal, depois eu até vejo se eu acho para você porque eu não estou achando mais. É um trabalho interessante porque é interdisciplinar, são todas as matérias falando a mesma língua, os conteúdos. Fui até onde deu, em determinado ponto em diante eu vi que não ia dar pé. Bom, eu falei, "Qual é a realidade do meu aluno? O que é importante para ele? É a família? É a família! É falar de preço, é falar de comida?”. Então vamos falar de comida! É falar do dia a dia, é falar de um plano futuro, de uma coisa que já foi? É descrever a cidade, é dar direções de como chegar a tal lugar? Principalmente porque nessa região, por conta do autódromo da cidade, tem muito turismo, acho que no comecinho de novembro, se não me engano, a gente tem corrida aqui. E o que vem de estrangeiros, eu falo "Gente, se vocês souberem inglês, no restaurante onde vocês trabalham para dar informação, poxa, é um negócio muito legal”. Então tem essa coisa do autódromo que já ajuda. Inclusive, quando eu comecei a dar aula em 2010, eu tive um aluno, excelente aluno, ele era mecânico de carros de Fórmula 1, ele falava, "Eu só não fui para fora do país porque eu não tinha o fundamental completo, porque eu 
não sei inglês". Aquilo era um negócio que doía para ele, ele era extremamente dedicado, ele dizia "Agora que eu terminei eu vou fazer um curso de inglês para me garantir", ele poderia ter ido trabalhar fora do país. Eu procuro ver o que é o mundo deles.

P: Nessa época, em 2010, você já era a professora dele?

M:Sim, sim, sim.

M:Até na época da corrida eu costumo fazer com eles vocabulário básico, race track é autódromo, formula um é formula one, só não usa o acento gráfico, mas é formula one. E algumas perguntas para pedir e responder informações, "How can I get to the restaurant?", e coisas do gênero. Eles se empolgam.

P: Eu vejo que os alunos ainda têm uma visão bastante tradicional de escola. Eu ainda vou tentar checar com eles, mas por que você acha que eles têm uma necessidade grande de copiar as coisas da lousa, de anotarem?

M:Isso P, é uma coisa que não é apenas dos alunos de EJA, dos regulares também. Os alunos da $7^{\mathrm{a}}$ série dizem “A professora não deu aula, ela só conversou com a gente". Para eles, é uma tradição, uma cultura escolar muito arraigada. Ainda é assim, ter aula ainda é encher o caderno. Do mesmo modo que o pai e a mãe quer ver o caderno cheio para falar que então o professor deu aula, os alunos de EJA também sentem a aula mais concreta com o caderno na mão cheio.

P: Eu gostaria de perguntar para eles, se é uma referência para eles depois. De repente eu é que estou com uma visão errada, pois eles vão usar o caderno depois para estudar em casa.

M:Olha, eu desconfio que não porque muitos deles não têm uma postura de aluno, um hábito de aluno. Todas as atividades que eu faço valendo nota é com consulta no caderno. Então eu falo, "Se vocês vêm na minha aula e copiarem tudo, vocês não terão problemas para fazer as atividades". Aí, eles falam "Você não passou isso". Eu passei, e está no seu caderno e você copiou.

P: Então, eu vi muito isso acontecendo quando você estava corrigindo.

M:E eles não acham o que copiaram, então eu deduzo que não é para consulta.

P: É pra que então? Vou perguntar para eles!

M: Tem alunos que realmente conseguem se achar. Eu falo, "Gente, procura tal data". Não vai. Tem aluno que você pega e coloca a lição aqui, aí ele pula 10 páginas e coloca aqui. Aí você fala, "Não pode. Sempre coloca a data, separa o caderno por matérias, coloca data para você se organizar, coloca o título".

P: É você ensinando o aluno a ser aluno, a como se organizar!

M:Eles não vêm prontos, eles tem uma outra experiência de vida, uma outra vivência.

P: A escolarização também é processo. Mas eu também vejo que a relação de construção de conhecimento está muito vista nesses diálogos que vocês tiveram. Pois é, se você não falou então não existe, se não está no caderno então não existe. Será que ele não poderia ter tido um pouco mais de autonomia para ir atrás? Como você vê essa postura do aluno? E essa postura sua também? No limite, você está ensinando ele a ser aluno, mas tem essa fluidez, ao mesmo tempo que você está ensinando ele a ser aluno ele também tem que ser autônomo.

M: Às vezes eu sinto que eles são muito dependentes. Eu normalmente sou super tranquila, mas eu já cheguei a ficar irritada, porque às vezes eles falam "Aí, por que você apagou?". Aí, eu digo "Mas você já tem no caderno". Então, eu sinto uma ansiedade muito grande, talvez estar na escola seja uma coisa muito nova que gere ansiedade e insegurança. Eu esqueci a sua pergunta.

P: Então, ao mesmo tempo que você está ensinando ele a ser aluno, também tem essa questão da autonomia, você acha que também cabe a você ensinar isso a eles?

M: Sim, sim, porque senão eles vão ficar, imagina, alguns deles vão para o ensino médio. Tudo bem, terceira etapa, estou pensando na terceira etapa, vai ser como lá? A ideia é ir soltando eles assim aos pouquinhos, do mesmo modo que a gente faz com o regular, porque é difícil uma pessoa que pergunta se é para pular linha, mas eles fazem muito isso, ou então, é aula dupla? É dobradinha? "Não gente, vocês sabem qual é nosso horário". Eu não sei se isso é uma insegurança, ou talvez de repente, tem aquela coisa da escola tradicional, tudo centrado no professor, tudo, tudo. Então eles não percebem que eu estou tentando delegar minha aula para eles quando a gente discute alguma coisa. Por isso a prioridade não é copiar porque a professora colocou na lousa. Não, é o momento de a gente conversar, roda de conversa, vamos trocar ideias, as nossas ideias, a ideia do grupo, vamos colocando na lousa. De repente, pode ser isso, a aula centrada no professor, eles devem ter isso dentro deles de algum modo, é uma coisa que eu evito ao máximo. Eu prefiro que eles falem mais do que eu, vamos ouvir o que eles tem a acrescentar, mas às vezes eles ....

P: Ou eles acham que não é aula, aquela coisa que você falou, quando eles estão debatendo, contribuindo com as experiências deles, com as ideias deles, eles sintam que não é propriamente uma aula, a aula para eles talvez seja o registro.

M: Mas aí é que está. É um registro que eles não vão saber utilizar, não todos, mas alguns você percebe que o caderno e nada é a mesma coisa. A segurança é segurar o caderno, mas se você pedir para ele achar alguma informação, ele não acha.

P: E como isso se relaciona com as novas tecnologias? Você vê que eles poderiam ter um pouco mais de autonomia buscando as informações, selecionando melhor as informações, como você disse mesmo, que muitos alunos não sabem? 
M: Eu acho que a principio é uma questão de exposição. Jogar eles na informática e ver o que acontece, e claro, ficar monitorando, igual a semana passada que você acompanhou a gente. Mas eu já cheguei a levar a sala, foi esse ano, e eu levei sozinha, sem ninguém, sem professor sem nada e foi uma loucura. Porque é assim, “Ah, e agora o que que eu faço", "Mas eu não consigo", "Eu não sei”, eles travam. Aí você imagina, um monte de adulto em pânico porque não consegue mexer no computador, e você é uma só pessoa. Aí, você diz, "Espera aí!”, para e diz: "Gente, olha para mim”. Aí explica, mas mesmo assim, se eu fosse para a sala de informática sozinha hoje eu não iria, porque é enlouquecedor.

P: Eles têm que ter o apoio do professor.

M:Sim, e muito.

P: Há alguma outra questão que você gostaria de falar? Agora é mais livre, o que você achou dessas perguntas que eu fiz?

$\mathrm{M}: E u$ achei que foram perguntas bem relevantes para o momento da educação que nós estamos vivendo. Uma coisa que as suas perguntas me lembraram, eu estava pensando isso outro dia, a gente discutiu isso uma vez na faculdade, na faculdade de educação. Eu não lembro qual era a professora, qual era a matéria, mas assim, a gente deve tomar muito cuidado com o novo, para nós não aceitarmos o novo por ser novo, e não negar a tradição por ser tradição, e vice e versa. Não aceitar o novo por ser novo e nem só aceitar abertamente a tradição por ser tradição. Então eu acho que tem que ter muito bom senso, muita conversa, realmente dar a cada coisa o seu devido valor. Eu vejo gente que acha que o tablet vai solucionar todos os problemas, não é assim. Educação pública, quem sou eu, eu estou aqui só há dois anos. Você vê coisas muito mais enraizadas, muito mais sérias que não vão ser resolvidas com um tablet. As pessoas dizem que tem que fazer o aluno ficar interessado, tudo bem, um tablet pode me ajudar, uma abordagem mais comunicativa, mais dinâmica, pode me ajudar, mas tem coisas que estão além do que a gente pode fazer. Isso é uma coisa que também precisa ser discutida. Não é só o equipamento, não é só a metodologia, não é só a afirmação do professor.

P: O que que é então?

M:Olha, eu tenho a sensação de fim dos tempos, é meio assustador! (risos)

P: (risos)

M:Mas se seu não tivesse experiência eu não estaria aqui.

P: É verdade.

M:Tenho que fazer a minha parte. Eu acho que algumas coisas se perderam. Eu acho que o papel da escola está muito claro para mim.

P: Qual é o papel da escola?

M:O papel da escola é fazer o aluno acordar para muitas coisas que às vezes a família..., para mostrar o que é o mundo, no mundo as coisas funcionam assim. Quando eu digo mundo, é o mundo do conhecimento, é o mundo do trabalho, é como lidar com as pessoas. Só que assim, chovendo no molhado como as pessoas falam, tem muita coisa que fica delegado para a escola que muitas vezes a função do conhecimento, que eu não vejo como transmissão.

P: Hoje eu tive um lance sério com essa coisa de transmissão.

M:Não é transmissão, mas é você colocar que quando o aluno fala ele pensa sobre o mundo, sobre a vida, o aluno pensa sobre a própria língua dele que ele não pensa. Fazer o aluno perceber que ele pode colocar VC no MSN, onde ele quiser, menos na redação de português, menos no formulário. Na redação que ele for preencher para trabalhar em algum lugar. Registro, eu falo muito de registro com eles.

P: Contexto, registro.

M:Sim, sim, fundamental. Eles não têm essa noção. Dentre outras coisas, a escola deveria trabalhar justamente com a questão do conhecimento, de fazer o aluno se interessar pelo conhecimento. Mas ultimamente não tem dado porque as coisas estão mudando e muita coisa fica delegada à escola. Como eu disse para você, muita coisa bem paternalista mesmo, do leite, o professor ele é meio tudo, ele acaba não sendo o que ele mais deveria ser P: O que que é? O que o professor deveria ser na sua visão?

M:Essa é uma pergunta .... O que eu tento ser, eu vejo por mim, o que eu me esforço para ser, estou sempre preocupada com a minha formação. Estou sempre estudando alguma coisa nova, estou sempre indo atrás de conhecimento e eu tento apresentar aquilo para o meu aluno de uma maneira relevante. $\mathrm{O}$ que eu posso conectar, o que eu falar para ele, ao mundo dele, eu faço. Eu comentei como você sobre uma experiência com o Shakespeare, que o aluno levou o livro e está adorando e hoje eu trouxe para eles assistirem "Dez coisas que eu odeio em você", que é baseado na "Megera Indomada". Comecei pelo filme mas a gente vai ter uma discussão maior sobre o que é o enredo. Eu tenho o livro em português, então a gente vai ler. Então assim, e foi, eles compraram a minha ideia, e você tem que estar acessível, tem que estar aberto. Se o aluno é adolescente, tem coisa que não é pessoal, é o momento da vida dele. Eu falo para os meus alunos, "Nossa! Vocês estão muito difíceis. Eu gosto, mas está difícil". E eu acho que você tem que gostar, porque quando você gosta vai ser só montanha russa. Você vai ter dias terríveis, vai ter dias que você gosta, aí volta, mas funciona. Mas se você não gosta, não gosta de gente, não gosta de aluno, você já não aguenta. Aí, não tem nada que você possa fazer por ele e eles por você, porque eles sempre trazem coisas novas, eles sempre acrescentam tudo, por mais que às vezes... 
Mas está difícil para todo mundo, essa é que é a verdade. Eu acho que é bem por aí. Se eu não acreditasse nisso eu não estaria aqui. Eu estaria fazendo alguma outra coisa da minha vida, mas é que eu gosto muito.

P: Você tem noção sobre as escolhas que você tem feito, principalmente sobre os materiais que você tem utilizado, no sentido de texto, de cultura, de questões ideológicas que possam estar envolvidas? Você pensa nisso quando você vai escolher os materiais?

M:Penso, em relação ao conteúdo eu procuro seguir, eu uso muita coisa de escola particular. Até listening, vamos no listening, funcionou com o texto e eles acompanhando. A questão ideológica eu não sei se estaria na escolha dos meus materiais, está mais no meu discurso em sala.

P: Bem claro, eu vi.

M:Eu evito entrar em algumas questões. Por exemplo, aborto. Aborto é uma questão que não discutiria porque..., não é aborto. Por exemplo, uso de drogas.

P: Porque é formação de opinião?

M:Não, é porque são assuntos...., ai é que tá.... Por exemplo, aborto não, uso de drogas, eu tenho que passar uma coisa como educadora, mas pessoalmente eu penso outra. Então, eu acho o seguinte, por exemplo, eu não usaria drogas, eu não ia apoiar ninguém para usar, mas se alguém usar, como é que eu vou interferir na vida dessa pessoa?

P: Mas como educadora você não poderia falar isso?

M:Nunca, nunca, nunca. Uma vez um aluno me falou, "Estou fumando maconha, o que que você acha?" Eu fui pega de surpresa. Eu falei, "O lance da maconha é o seguinte: nosso cérebro é formado por neurônios, o neurônio é uma célula neurótica". Eu expliquei mais ou menos tal, "O lance é o seguinte, cada vez que o neurônio morre não nasce outro no lugar e a maconha mata os neurônios. Isso quer dizer o quê?". Aí ele ficou me olhando e disse, "Ah tá bom, obrigado". Então quando os alunos trazem questões que eu não sei por onde ir, eu tento mostrar que eu estou aberta. Muitas vezes eles vêm com essas coisas e é bom a gente saber o que está acontecendo com eles. Aí eu parto para o científico.

P: Por que o científico?

M:Porque eu acho menos comprometedor. Não que eu não queira me comprometer, mas são coisas muito pessoais. Porque, por exemplo, o aborto, eu posso falar sobre valorização da vida? Posso, mas se uma aluna minha for estuprada e engravidar, como é que eu vou falar para ela "Não aborte"? Apesar de eu ser contra o aborto. Você entende? Então assim, são realidades muito diferentes da minha. Eu não posso chegar e falar "Isso aqui está errado isso está certo". É muito sério. Então eu procuro relativizar o que dá, mas tem coisa que, óbvio, por exemplo, sei lá bullying, do respeito, de você tratar os outros direito porque você vai querer sem bem tratado. Mas tem assuntos que eu simplesmente fico mais reticente por..., acho que por eu não saber me colocar mesmo. Se chegasse uma pessoa e me perguntasse eu faço ou não faço um aborto, eu não saberia o que dizer, parte de mim diria que não, tenha esse neném, mas não é simples assim. Não podemos ser simplistas. Cada um tem uma história de vida, cada caso é um caso.

P: Enfim, bateu o sinal. Continuaria perguntando, mas temos que entrar em aula. Eu gostei bastante das contribuições que você deu. 


\section{Apêndice 8 - Entrevista com as alunas E. e N. (Centro Educacional Trandisciplinar) em 31 de outubro de 2012}

Realizada após o término da aula.

P: Essas histórias que vocês contam, imagina... é superinteressante, são dados importantes. O jeito como vocês contam as coisas pra mim, é legal.

E: Então, e a outra não estava triste na sala. Ah, vou sentir falta, da cara da G.. A G. entrou e falou assim: "Hoje é o professor?", daí não, hoje é a teacher.

(risos) Vívian chega. Alunas comentam que no dia anterior, quando não tiveram aula com a professora, foi o aniversário dela, e dão os parabéns. E. diz "Eu sei cantar parabéns: Happy birthday to you"

E: Parabéns, teacher. Deus te abençoe e te dê bastante saúde. E te dê paciência com esse bando de... (?)

[risos]

V: Imagina, tenho sim. Vocês são muito legaizinhos.

P: Imagina, vocês são maravilhosos.

V: Esse negócio de... Muitas vezes se desvalorizam. Eu vejo assim, às vezes, muitos de vocês às vezes falam assim “Ai, teacher, ai professora, tem que ter paciência com a gente, porque a gente não consegue.” É que muita gente, muitas pessoas da sala começaram a estudar esse ano ou ano passado, ou então fazia muito tempo que não estudava. Então, desacostumou com essa vida escolar. Por isso demora um pouquinho mais.

E: Primeira professora foi a professora L., que eu tenho o maior carinho.

V: Deixa agora a P fazer o trabalho dela com vocês. Beijo, até mais.

P: Até mais, Vívian.

V: Vamos lá, sempre se valorizando!

E: Não, teacher... (a entonação parece a de uma justificativa, aparentemente, de que falou aquilo por brincadeira ou modo de dizer?)

$\mathrm{V}$ : A gente chega lá.

E: É sério? (Não falei me desvalorizando...) (risos)

P: Claro. Posso começar então por você, E.?

E: Pode.

P: Então, E., você mora no bairro da XXX, mas você nasceu em São Paulo?

E: Não. Eu nasci em Minas. Em Mantenas.

P: E quando e por que você veio morar em São Paulo?

E: Eu vim com uma senhora porque eu sempre tive o sonho de morar em São Paulo, desde pequena. Lá em Mantena todo mundo vinha pra cidade grande, né. E eu falava, "Quero um dia morar em São Paulo". E eu adoro aqui mesmo, com todas as dificuldades, eu adoro essa cidade. Mas calhou que apareceu uma senhora em Mantena, para trabalhar, pra cuidar da mãe dela aqui em São Paulo, a D. M.. E com quem eu fiquei muitos anos até ela falecer. Aí depois que ela faleceu eu decidi que não ia mais trabalhar em casa de família, que eu me apeguei muito com a patroa, né.

P: Você chegou a morar com ela?

E: Não, não. Tanto na semana que ela faleceu eu emagreci quatro quilos. Me apeguei com ela mesmo e ela comigo. Porque ela já era doente. Então, depois fui trabalhar na fábrica de antenas no Pari. E de lá que eu conheci meu esposo e aí foi desenrolando as coisas.

P: N., você também não nasceu em São Paulo, pelo que você nos contou naquela conversa em grupo. Onde você nasceu?

$\mathrm{N}$ : Eu nasci na Bahia, em Vitória da Conquista.

P: Sim, e por que você veio pra cá?

N: Da primeira vez, eu vim conhecer. Eu tinha vontade de conhecer São Paulo. Aí minhas irmãs todas, a maioria morava aqui. Eu vim pra passear. Cheguei e gostei. Aí, eu parei de estudar.

P: Por que você parou de estudar?

$\mathrm{N}$ : Porque eu tinha que trabalhar, né. Ou trabalhava ou estudava, não tinha como...

P: Na sua estrutura de família, seus irmãos estudavam?

$\mathrm{N}$ : Não, nenhum dos meus irmãos queria estudar. Só tinha eu mesmo que tinha que estudar. Aí comecei a trabalhar e não tinha condições pra estudar. Aí quando voltei agora de novo. Fui lá e voltei faz dois anos.

P: Voltou pra lá por dois anos por quê?

N: Fui ficar com meu pai, porque ele estava doente. Aí ele faleceu, fiquei lá dois anos e voltei. Aí quando voltei, eu vim com vontade de estudar. Terminar meus estudos.

P: Terminar, então você começou a estudar lá em Vitória da Conquista.

N: Não, comecei aqui. Comecei agora no Centro Educacional Trandisciplinar.

P: Agora no Centro Educacional Trandisciplinar? Você se alfabetizou aqui? 
N: Não, aqui não. Estudei lá até a $6^{\text {a }}$ (série). Mas eu voltei aqui agora. Então eu arrumei trabalho em um bairro próximo, só que eu arrumei trabalho pra noite. Então eu procurei o Centro Educacional Trandisciplinar, porque eu poderia fazer de manhã, trabalhar à noite.

P: Sim. Qual é seu emprego agora? Aqui no questionário você colocou que é atendente. Me explica como é sua função, como você faz o atendimento.

$\mathrm{N}$ : É muito bom, assim, saber como lidar com as pessoas. Tem gente que às vezes são muito chatas. Outras são muito boas. Então você começa a lidar com várias pessoas.

$\mathrm{P}: \mathrm{Ah}, \mathrm{sim}$. E que empresa que é, eu não entendi.

$\mathrm{N}$ : É uma lanchonete de acarajé.

P: Ah, tem uma ligação com a Bahia.

$\mathrm{N}$ : Tem.

P: Agora, você E., é faxineira onde?

E: Em escritório. Sempre trabalhei de faxina em escritório. Agora onde eu estou trabalhando, eu estou indo a cada quinze dias porque está falindo. É uma gráfica no Anhangabaú. Saio daqui correndo, pego o ônibus. Onde eu fiquei muitos anos foi na loja XXX, na avenida XXXX. Eu casei, fui morar na rua do túnel e trabalhava na loja XXXXX. Só que fazia limpeza no escritório e fazia comida pro meu patrão. Agora faliu, passo lá e fico com muita dó porque a parede lá da empresa tá toda pichada. E eles venderam e foram pra Minas. E agora eu estou com esse bico aí, e eu estava passando roupa pra fora também, que tem bastante clientela. Mas eu parei porque minha tendinite estava inflamando muito.

P: Pelo trabalho manual, né.

E: Isso, pesado. Excesso de exercício de um lado só. Uma que eu sou canhota e esse trabalho já é mais pesado. Meus filhos todos graças a Deus estão tudo trabalhando, bem encaminhados mesmo.

P: Seus filhos concluíram os estudos? Que idade eles têm?

E: Eu tenho um com 32, um com 29 e um com 26.

P: São três, né. E qual a escolaridade deles?

E: Bem, o J. fechou a faculdade agora por causa do horário.

P: Mas ele está na faculdade?

E: Já. Analista de sistema, que é a área que ele trabalha.

P: Interessante.

E: E o de 32 trabalha há muitos anos na XXXX? Ele toma conta de tudo lá.

P: Qual a escolaridade dele?

E: Ele terminou também os estudos. Os estudos eu sei que ele terminou o segundo grau completo.

P: E o mais novo?

E: O mais novo fez o primeiro grau completo e parou. Ele é motorista faz anos também, motorista de empresa.

P: Bem, o que levou você a retomar os estudos?

E: Pra mim, eu não sabia nada quando eu entrei aqui. Eu tentei entrar no Sesi, mas eu não acompanhava porque tem aula na televisão. Então eu não acompanhei. É bem mais perto de casa o Sesi, só que eu não acompanhei de jeito nenhum. O que que eu fiz? Foi uma vizinha que me falou dessa escola aqui, acho que há três, quatro anos atrás. Então eu...

P: Você se matriculou.

E: Fui, com a professora L., com a professora V.. E tô...

P: Agora na $3^{\circ}$ módulo, com mais professores, né.

E: Isso.

P: É a primeira vez que vocês estão tendo aulas de Inglês.

E: É, a primeira vez.

$\mathrm{N}$ : Eu já tinha tido, estudei até a $6^{\mathrm{a}}$ série.

P: Então me contem um pouco o que pensam sobre as aulas de Inglês e sobre aulas de informática.

$\mathrm{N}$ : Informática eu estou começando tudo aqui, né. Antes eu fiz um curso, mas eu fiz só até a metade, eu não terminei. Mas o Inglês pra mim eu já sei bem também a metade, né. Algumas coisas novas que estão entrando aqui agora, aí eu não sei, estou aprendendo aqui. Mas mais pra frente eu sei que vou aprender mais coisas novas, por isso que eu me dediquei a voltar a estudar porque só pela metade, você esquece tudo.

P: É, sim. E você, E.?

E: Eu... Olha, pra mim tudo é novidade, né. Eu nunca estudei, assim, né. Informática, eu quero aprender informática mas do modo que... as palavras, o que significa. Aquelas coisinhas que o professor não....Ele passa a lição, entendeu... A gente já faz a liçãozinha que ele passa. Mas eu não entendo nada de computador, eu quero aprender. Mas meu esposo comprou um computador.

P: Então vocês têm um computador...

$\mathrm{N}$ : Eu não tenho. 
E: Tenho sim. Só que eu passo por ele, ele fica lá tampadinho. Passo pra lá, passo pra cá, ainda não tive. Agora nas férias que eu quero pegar firme pra aprender, entender o computador. Pra mim tudo é novidade, aula de Inglês, computação, é tudo novidade.

P: Aqui no questionário você colocou sites que você costuma acessar, "Outros", porque nenhum desses que eu listei você usa, mas não colocou quais...

E: Então, quase nenhum. (risos) Por isso que eu pus até à lápis, só os que eu aprendo na escola.

P: Sim, só os que o professor indica. Agora, conversando eu entendi. Já a N., apesar de não ter computador, acessa da lan house.

$\mathrm{N}$ : Aham. Eu acesso daqui da escola também, quando eu termino a lição, aí eu entro na internet também.

P: Ah, é, o professor libera a internet pra mexer? E que sites você acessa? [lendo o questionário que N. havia respondido algumas aulas antes] Redes sociais, programas de TV, quais?

$\mathrm{N}$ : Quase todos.

P: Quais? Você pode me dar alguns exemplos?

N: Gosto de olhar as receitas do Hoje em Dia.

P: Eu também. [risos] Muito bom, porque eu não consigo anotar na hora que tá passando, então eu olho na internet.... [voltando pra lista] Jogos.

$\mathrm{N}$ : Jogos de celular mesmo.

P: E o Google? O que você costuma ver no Google?

$\mathrm{N}$ : Às vezes eu gosto de ver sites diferentes. Gosto de procurar receitas novas...

P: Então, como o Google é um site de buscas, você pode procurar muitas coisas, às vezes você escreve uma palavra lá...

N: Uma palavra que você não conhece, você acha estranho, você nunca ouviu, aí você pode procurar.

P: É sim. Bate-papo, você conversa com as pessoas no bate-papo?

$\mathrm{N}$ : É, do meu celular.

P: Você já conversou em Inglês com alguém no bate-papo?

$\mathrm{N}$ : Ainda não.

P: Ainda não? Aí tem essa pergunta aqui, né. Além do que você costuma fazer na internet, o que você costuma aprender, mesmo que essas duas coisas aconteçam meio que ao mesmo tempo. Você colocou muitas coisas na sua resposta sobre computação, notícias, cursos, trabalho. Você pode comentar um pouco mais sobre isso?

$\mathrm{N}$ : Eu estou procurando fazer um curso de... não lembro o nome agora... Estou procurando na internet algum lugar em que eu possa fazer esse curso de graça ou então mais barato... Lembrei, arquiteta. É meu sonho fazer o curso de arquiteta, por isso eu planejei fazer aquela casinha de boneca, tudo pela minha mente mesmo. Aí é meu sonho fazer esse curso.

P: O arquiteto hoje em dia, além de saber desenhar tem que ter muita noção de...

E: De estudo, de dedicação.

P: De programação de computador.

$\mathrm{N}$ : Desenhar bastante planta.

P: Hoje em dia eles desenham plantas tudo com programação do computador. Tem que saber desenhar, claro, mas tem muitos programas de computador que ajudam eles, né. Ok. E., a sua aprendizagem na internet é muito mais mesmo de digitação, você disse que sente que está escrevendo corretamente e você aprende a ler e a escrever. Está mais relacionado às bases de ler e escrever. É um desafio para você a internet?

E: Não, a internet não é um desafio. Para mim, tudo o que eu aprender é para mim, né, é bom. Não tenho que "Ai, eu tenho que" (voz alterada para simular exagero), não. Tudo tem que ter limite, como eu tenho, o que eu quero é aprender, não quero parar. Já que agora os meus filhos estão adultos e dá para eu sentar numa sala de aula, eu estou me achando, estou me sentindo uma criança. Estou me sentindo, "eu tô que tô". Graças a Deus, não tenho...

$\mathrm{N}$ : Até a minha irmã mais velha ela está com vontade de estudar também. Às vezes ela fala, “Ai, $\underline{\mathbf{N}}$., você está tão bem estudando...”. E ela entra no trabalho às nove e meia também, quase dez horas. Aí, dava muito bem para ela estudar de manhã.

E: Estudo é uma bênção.

$\mathrm{N}$ : Aí, quando eu chego lá ela fala, “Ai, N., dá vontade de estudar". A minha outra irmã também parou de estudar, as minhas irmãs todas pararam de estudar muito novas.

P: Por quê?

$\mathrm{N}$ : Algumas mais falta de oportunidade mesmo.

P: Mas você está estudando...

$\mathrm{N}$ : Elas tinham que trabalhar naquele tempo. Como eu fui a última, meu pai não queria que eu parasse de estudar. Mas aí, eu vim conhecer São Paulo e parei.

P: Entendi. Mas deixa eu entender uma coisa, N. Suas irmãs estão lá na Bahia, estão aqui em São Paulo?

$\mathrm{N}$ : Não, tem duas aqui e o resto está lá.

P: E as que estão aqui estão estudando? 
$\mathrm{N}$ : As que estão aqui estão com vontade de estudar.

P: Mas por que você acha que elas estão com vontade de estudar? Por que você está estudando?

$\mathrm{N}$ : Elas me falam. Às vezem elas me veem estudando lá, desenhando alguma coisa, aí elas falam, "Nossa, aí dá vontade de estudar!".

P: Interessante! E., quando você via seus filhos estudando você não tinha vontade de voltar a estudar também?

E: Eu não podia. Meu esposo fala para todo mundo, quem cuidou dos filhos foi a E. Ele saía muito cedo e chegava muito tarde.

P: E., você tinha muitas tarefas?

E: Tinha. Então, eu sempre trabalhei na casa de outros, fazia meus bicos, fazia doce para fora também. Quer dizer, a minha oportunidade mesmo é agora. Agora é que eu posso falar para você, hoje eu posso falar assim, você vai na minha casa passar uma roupa hoje? Não posso não, de jeito nenhum, isso eu posso fazer hoje, não antes eu não podia porque eu tinha que ajudar o meu esposo. Mas valeu a pena.

P: O que que aconteceu? Ele está ganhando melhor? Você está ganhando melhor?

E: Ele está ganhando melhor depois que ele se aposentou.

P: Mudou a estrutura da família.

E: Graças a Deus. Mudou muito, para melhor. Por isso que eu falo para você. Eu não posso estar pedindo, reclamando...

P: Tem que entender as condições também, né.

$\mathrm{N}$ : Quando eu arrumei a vaga na escola também para estudar à noite, que eu fui andar, de baixo de chuva, para fazer minha matrícula, quando eu arrumei um trabalho para noite eu fiquei de ir lá falar para ela que eu não ia poder estudar. Porque ou eu trabalhava ou eu estudava. A gente não tem pai nem mãe, aí cada um depende da gente, né. Ou trabalha ou estuda. Mas aí ela foi tão gentil que ela procurou este colégio e me indicou. Nossa, foi uma alegria para mim, porque eu ia ficar sem estudar de novo o ano inteiro. Ia ser demais.

P: Mais um ano, né? Bom, N., você disse que queria fazer a faculdade de Arquitetura.

$\mathrm{N}$ : Quero terminar meus estudos, quero fazer a faculdade, porque hoje em dia não arruma um trabalho bom se você não tem os estudos completos. Quase todo trabalho que você vai, pede o segundo grau completo. Se você não tiver, você não trabalha.

P: Você colocou aqui [no questionário] que o Inglês é uma coisa que você consegue, aqui por exemplo, palavras conhecidas, você vê na internet palavras conhecidas, e também devemos assistir filmes em inglês para tentar decifrar. Como você explica essa palavra decifrar?

$\mathrm{N}$ : Decifrar, por exemplo, eu ouvi esses dias uma reportagem no Globo Repórter com um rapaz falando que ele aprendeu inglês ouvindo pelo rádio. Ele ouvia as palavras e ia anotando, mesmo sendo errado. Mas depois ele ia decifrando tudo. E foi assim que ele aprendeu o inglês dele. Aí, sempre que eu vejo uma palavra aqui, eu tento procurar na internet, ver se é certo ou não. No dicionário em Inglês. Eu acho que a atitude das pessoas que estão aprendendo assim, igual ele, hoje ele é um... (???) no exterior falando com as pessoas em inglês pelo que ele aprendeu no rádio. Eu achei muito bonita a atitude dele.

P: Como que você coloca essa questão do inglês e da tecnologia no mundo de hoje? Como isso pode ajudar, atrapalhar?

$\mathrm{N}$ : Bem importante na vida da gente. Porque às vezes você pode, de repente, mudar para outro país e se você só fala português, você tem que aprender o inglês para chegar lá e comunicar com as pessoas em inglês.

P: Você se vê mudando para outro país, N.?

$\mathrm{N}$ : Eu não.

P: Por quê?

$\mathrm{N}$ : Eu não, só se eu for fazer uma faculdade fora.

P: Pense, você já se mudou de um lugar diferente, saindo de Vitória da Conquista e vindo para São Paulo e você também, né, E.

N: É.

E: Isso para mim é uma bênção.

P: Não que seja melhor vir para São Paulo, não é isso o que eu estou falando. Mas é uma mudança grande.

E: Foi melhor. Para mim, foi melhor.

P: Por quê?

E: Porque aqui eu já comecei, lá eu ia para a roça. O que que a gente ganhava na roça? Nada. E aqui, o tanto que eu fiquei com a dona M., não pagava nada, morava com ela. Eu comprei fogão para a minha mãe, comprei um radinho...Todo ano eu ia e já levava umas coisas para ela. Então deu. Mas o sonho mesmo era comprar uma casinha para ela lá, já não deu. Mas em compensação, o aluguel lá é muito baratinho, então ela falava "Ai, E., não esquenta a cabeça não. Não esquenta a cabeça”. Que as coisas eram muito baratas. É mais barato lá.

P: Já passou bastante do horário que eu tinha combinado com vocês, mas muito obrigada pela colaboração. Ótima!

E: Se precisar de alguma coisa...

P: Adorei. 


\section{Apêndice 9 - Aula $3^{\circ}$ D (Centro Educacional Transdisciplinar) - Trecho de A Hora da Estrela, de Clarice Lispector em 31 de outubro de 2012}

Aula ocorrida em 31 de outubro de 2012, a pedido da coordenação do CENTRO EDUCACIONAL TRANDISCIPLINAR, após a professora Vívian passar mal e ser encaminhada ao hospital. Como se tratou de uma emergência, a aula ocorreu improvisadamente como uma leitura interpretativa do trecho citado, que constava do material didático e que provavelmente seria utilizado nas próximas aulas.

P: O destaque quer dizer, a pessoa quer ser notada para os outros, por um lado, por quê?

B1: Ser reconhecido socialmente.(...) Não só nordestino.

P: Não só nordestino, tem muitas pessoas.

A1: Muitos. Vem da Bahia, vem de tudo quanto é lugar. Em São Paulo, que não tem onde morar, não tem moradia digna. (...) Não é fácil.

P: Sim. Por outro lado, o destaque também é para si.

B2: Para sua autoestima.

P: Para sua autoestima. Não é verdade? Por quê? Eu acho que tem uma relação com os dois lados, porque a gente inclusive até começa a falar, pensem bem, para se comunicar com outras pessoas. A gente não existe Sem outras pessoas. Já pensaram nisso? O bebê do ser humano é o único animal que não sobrevive se ficar sozinho no mundo. Os outros animais sobrevivem. Se deixar um cachorrinho abandonado sozinho, ele consegue se virar. Um bebê, não. O bebê precisa não é só de leite, né. Não é só alimentação. É cuidado, é carinho, são outras muitas coisas. E aí vem o reconhecimento das outras pessoas e é onde vem a autoestima também.

(B3 sinaliza que quer comentar algo)

P: Fala, seu B3...

B3: Isto ocorre por conta do paternalismo excessivo do ser humano?

P: Também pode ser. Me explique mais isso.

B3: O animal, como foi dito agora, que ele se cuida sozinho porque no reino animal ela costuma dar liberdade, ela policia, ela não paparica. Possivelmente por isso que o ser humano costuma ter toda essa dependência.

P: Por isso que você diz assim, "Eu sou muito mais a favor de que o destaque seja para mim e não para os outros". Porque você não gosta tanto dessa ideia de que a gente seja tão paternalista, né? Fique tanto na dependência.

B3: Policiamento, sim. Não tanta assessoria, porque de repente até prejudica e não dá tanta criatividade. Dá dependência. A hora que cai uma pedra na cabeça vai cair o mundo.

P: Gente, alguém me ajuda? (risos)

B4: Acho que o instinto animal está na natureza mesmo.

B5: O que ele quis dizer, professora, ..... entendeu?

B2: Mas isso é que às vezes, é desde a barriga. Quando a gente sabe que está grávida, já começa aquela coisa e os animais não têm isso. É muito mais um instinto, né. Com os animais não tem isso.

P: É mais simples. O ser humano tem muitas, muitas, muitas variáveis. Muitas outras questões.

B2: Com certeza a vida animal é muito melhor porque ele sabe sobreviver sozinho. Não só os bebês, até a gente que é adulto precisa.

P: Até a gente que é adulto tem essa questão também.

B2: Com certeza.

B3: Passou domingo no Faustão umas cabras montanhesas. Um dos bebês que estava subindo o morro, perdeu o controle e desceu despinguelado. Ele não rolou, ele desceu. A mãe já estava lá em cima. Ela não se ligou não, ficou lá em cima olhando. O bebê subiu de novo. Quer dizer...

B2: Se fosse um ser humano ia se jogar junto, ia morrer junto.

B3: Aí é que eu me refiro. Eu penso que seria quanto às facilidades do mundo...

B6: Mas aí, é o que eu falo....(...) Porque não sabia rezar.

(Risos)

P: Como é que é? Não entendi, como é que é?

B6: As pessoas falam, como é que o cachorro entrou na igreja? Porque a porta estava aberta. Por que ele saiu? Porque não sabia rezar.

B2: É, não é igual a gente que pensa.

P: Que tem uma cultura.

Antonio: ...(...)

B2: Não é gente não, é uma cabrinha.

P: É uma cabrinha, uma cabrita.

B3: Intepretação sua.

P: Olha, muito interessante. Até tem mãe que tem essas questões. Mas você acha que ela consegue assumir isso para os outros? 
B6: Não tem aqueles mulheres que usam drogas, que os filhos já nascem dependentes de drogas? E quando eles nascem, umas querem se recuperar, outras são incuráveis.

B1:Já sofre de abstinência.

B2:(?)

P: O bebê já sofre.

B6: (?)

P: Bom, voltando ao texto, tem uma pergunta que eu quero fazer também. Quando a gente começa a tentar a se perguntar quem somos nós, nós nos tornamos incompletos. Isso tem vários sentidos. Um sentido que a R. deu foi o de ter necessidade de ir atrás das coisas e isso pode ser bom. Tem outros sentidos que vocês dão também para essa questão de se tornar incompleto?

B3: Tem.

P: Quais sentidos?

B3: A ausência de um ente querido que poderia talvez ser ouvido ou a relação de família.

P: Isso não é o outro? Isso não é a questão do outro que você disse que "Ah, tem muita dependência! "

B3: Existem os casos que são assim. Esse tipo de formação. No caso da formação. Que é o...

P: A questão da ausência do ente querido. Amigos?

B3: Pode até ser.

P: Outro sentido? Vamos para o próximo paragrafo? A3 já leu, agora é o A7. Sim?

B7: "Ela nascera com maus antecedentes e agora parecia uma filha de não-sei-o-quê com ar de se desculpar por ocupar espaço. No espelho distraidamente examinou as manchas do rosto. Em Alagoas chamavam-se 'panos', diziam que vinham do fígado. Disfarçava os panos com grossa camada de pó branco e se ficava meio caiada era melhor que o pardacento. Ela toda era um pouco encardida pois raramente se lavava. De dia usava saia e blusa, de noite dormia de combinação. Uma colega de quarto não sabia como avisar-lhe que seu cheiro era murrinhento. E como não sabia, ficou por isso mesmo, pois tinha medo de ofendê-la. Nada nela era iridescente, embora a pele do rosto entre as manchas tivesse um leve brilho de opala. Mas não importava. Ninguém olhava para ela na rua, ela era café frio."

P: Bem. No começo do trecho o narrador mostrou para a gente um lado o quê? Como vocês poderiam, que frase, que palavra vocês poderiam dar para esse narrador no começo? Sobre a Macabéa? Ela tem uma vida sofrida...

B1: Não reconhecida.

P: Não reconhecida, não se conhecia, não sabia onde era o botão de acender, inclusive, né. A gente até falou sobre família, sobre reconhecimento, sobre lutar, ir atrás das coisas. Agora, o que esse narrador fez com ela?

C: Um ser humano, está vendo que a pessoa está sofrendo. Vai lá e critica.

P: Está criticando ela negativamente. Nem sempre criticar é ruim, mas nesse caso, ele está criticando negativamente .

B3: Está reduzindo mais ainda a autoestima da pessoa.

P: Mas e aí? Que provas vocês têm sobre essa visão do narrador? Do texto? Que palavras, que frases ele usa para dar essa visão crítica dele?

B6: Iridescente.

(?):Caiada.

(?):Pardacenta.

P: Murrinhenta. Na verdade, ela tinha um cheiro morrinhento. Eu não tenho certeza, mas não deve ser algo bom. Vocês conhecem essa palavra? Tem um cheiro morrinhento?

B2: Um cheiro ruim.

P: Fedida? O que mais?

B6: Encardida.

P: Encardida.

B2: É suja.

P: Quer dizer que é suja, mal lavado. O que mais?

B7: Grossa. Grossa.

P: Grossa. Por falta de educação ou ignorante. Bem, no começo, estou ligando com o que o seu C. falou. A pessoa tem um vazio por causa da família, na ausência de um ente querido.A moça sabia o que ela era?

P: Não sabia. Sabia? Olha lá no texto.

B2: Ela era sebosa.

(risos)

P: Ela era sebosa. Como a gente sabe que ela não sabia? Olha no começo do trecho, lá na primeira linha. B7, lê de novo para a gente?

B7: Ela nascerá com maus antecedentes.

P: Desculpa, ela nascera. (ênfase na pronúncia correta). Nascerá é futuro.

B7: Nascera...

P: Nascera, gente, nascera é... 
B3: Passado.

P: Passado, passado mais que perfeito. A gente nem usa muito, mas na literatura, escrita poética, sim. Ok, B7, desculpa.

B7: "Ela nascera com maus antecedentes e agora parecia uma filha de não-sei-o-quê com ar de se desculpar por ocupar espaço"

P: Filha-de-não-sei-o-quê... Poderiam me explicar, gente? O que é isso? Filha-de-não-sei-o-quê.

B3: Que não tem dedicação.

B1: Que não tem dedicação.

B6: Nordestino?

P: Ok, eu entendi duas coisas dessa expressão. Vamos ver se vocês concordam comigo.

B3: É a filha daquela mulher do "decentarro".

P: Hum? "Decentarro"? Será que ser um filho-de-não-sei-o-quê é a mesma coisa que ser o filho do Eike Batista?

B3: Negativo.

P: Será que se você fosse filho do Eike Batista você seria chamado de filho-de-não-sei-o-quê?

B8: Quem é o Eike Batista?

B3: Você não sabe? O Thor Batista? O Thor é aquele que bateu com o carro lá.

B8: Ele só ficou famoso por causa do acidente.

B2: Exatamente, você sabe. Você sabe do que a gente está falando. Você é bem informado.

P: Tudo bem, já foi o motivo para você ficar sabendo.

B6: Eu estou confundindo, professora, esse nome que você falou, com aquele cara como é que chama aquele cara que morou fora do país e tinha uma grana violenta? Se eu não me engano na Itália.

B8: O B6.

B6: Isso, junto com o B8.

(risos)

B6: Como é que chama?

B3: Que fez um monte de plástica? O nome é...

B9: Abade.

B2: Abade? Abade! Abade!

B3: Abade.

B4: Abadia.

P: Abadia. Sim, sim, sim. Bem, aí estamos falando de várias coisas. Por isso que uma das coisas que eu entendi que é quando chama de filho de rato, filho-de-não-sei-o-quê...

B5: É um desprezo.

P: É um desprezo por quê? A pessoa que um filho-de-não-sei-o-quê é uma pessoa que não tem o quê?

B4: Valor.

P: Não tem valor por quê?

B1: Porque não é rico, não tem dinheiro.

B3: Não é reconhecido pela sociedade.

P: Não é reconhecido pela sociedade, lembra que a gente já tinha falado isso? Por quê? Não tem...

B3: Estrutura.

P: Estrutura que vem do quê, gente?

B3: Procedência.

P: Procedência, do quê?

B5: Do nome, da família.

P: Que vem do nome, da família, reconhecimento, entendeu? Tudo isso está envolvido. A Macabéa é uma filhade-não-sei-o-quê. Nascida no Nordeste. Gente, será que, desculpem, será que é o narrador mesmo falando por ele mesmo que está falando isso ou ele está falando por muitas pessoas que falam desse jeito?

B3: Que falam, que são consideradas assim e que infelizmente têm esse comportamento por conta de uma única coisa que eu acho que é muito triste na sociedade.

P: Que somos nós, né? A sociedade somos nós também. Interessante isso, a gente vê que tem muita gente que pensa assim como ele está descrevendo. É mais ou menos assim, ele está falando e a gente até acha estranho, né. Ué, mas ele não falou que gostaria de contar, que todo mundo deveria conhecer a história dessa pessoa? E de repente ele começa a (faz gesto martelando a mesa).

B3: Dá como se fosse a paulada.

P: Dá paulada nela. Então, é para a gente começar a desconfiar. Por que será que ele está falando isso dela? Estamos falando de muitas coisas, inclusive de preconceito, nesse sentido. Certo? Talvez ela seja mesmo suja, encardida. Talvez ela seja. É que é ele contando, né. A gente não está vendo ela. Mas ele está envolvendo a gente na história. Sim?

B6: Sim.

P: Ok? Mas vocês acham que tem gente que falaria isso de alguém, que vocês conhecem? 
B3: Sim.

Vários: Oh, se tem.

B5: Vixi, nossa. É o que mais tem. Gente para julgar as pessoas.

B3: Ali em Itaquera tem um cidadão que se você estiver passando de um lado da rua, você deixa ele terminar de passar para continuar.

B5: Não precisa ir tão longe não. Lá de baixo você sente o cheiro dele.

B3: (?)

P: Realmente tem os fatos, mas existe também gente que fala "Porque tem essa pessoa que é assim", então já generaliza.

B6: (?)

P: Que você fica até envergonhado de ouvir a pessoa falando, né? Isso diz alguma coisa contra nordestinos ou pessoas que não tem uma família reconhecida?

B1: Eu tinha uma vizinha que era insuportável. Ela morou na periferia, criou-se na periferia, para ela todo mundo era "favelado" (imitando o jeito da vizinha falar, com desdém). "Essa nega de cabelo para cima, bando de analfabeto!". "Mas Maria, você chama os outros de favelado, você morou sempre onde?" "Aqui!" "Você criou seus filhos onde?" “Aqui!" "Então você é favelada! Por que você julga as pessoas?”. Ela é in-su-por-tá-vel. Insuportável.

B2: Essas pessoas que criticam as outras são as piores.

B1: Ela exagera muito, muito. E a única pessoa que conversava com ela era eu, da rua. Eu pedia a Deus para ter paciência para não ser mal educada com ela porque é horrível ficar com uma pessoa criticando, falando mal, com discriminação. "Ai, meu filho arrumou aí"... O fillho mais velho dela tem 40 anos e nunca casou porque ela não deixa ele namorar. Arrumou uma moça linda, porque é mãe de um filho, mãe solteira, "Não, ela é mãe solteira, não é para o meu filho!"

P: E ela era casada quando teve ele?

B1: Era.

P: Ah, tá.

B2: O que as pessoas falam dos outros está dizendo...(?)

P: Já ia falar isso. O que você fala das outras pessoas diz muito sobre você.

B4: Mas é, tá certo. Esse negócio de cheiro. ...? Cutucando uma pessoa, diversas pessoas. Por exemplo, dentro do ônibus. A pessoa está lá.

B6: Mas às vezes acontece, que nem aconteceu comigo, com um funcionário. Se você chegasse perto dele, você sentia um cheiro de peixe, um cheiro muito forte de peixe. Eu pensava, "Será que esse cara trabalha numa peixaria à noite?". Um dia eu fui conversar com ele, fui trocar uma ideia. Aí ele me ouviu, "Tem algumas pessoas reclamando, assim, assim, assim...". Ele começou a chorar. Falou, "Vou falar para você, eu tenho vergonha. Eu estou fazendo um tratamento. Meu problema está no sangue. Toda vez que eu vejo que fico nervoso, estressado, eu transpiro, pelos meus poros sai esse cheiro horrível. Também eu não suporto. Estou fazendo tratamento, só que se eu me afastar do serviço, eu posso perder o emprego". Aí, passei para a frente da diretoria, a diretoria afastou ele para ele fazer o tratamento. Ele fez o tratamento, voltou outra pessoa, voltou a autoestima do cara. Está trabalhando muito melhor. Isso é um problema das pessoas, julgar as pessoas sem saber. B1: Esse cheiro de peixe apodrecido que a pessoa tem já ouvi falar que podia ser câncer, sabia?

B6: Lá do lado do metrô no centro de Itaquera tem um rapaz que se você passar por lá você vai ver ele lá. Grandão, fortão, tudo. Está dormindo na rua, está usando crack, usando droga. Conheço, a família dele tem um sobrado. Adivinha por que a família dele mandou ele embora de casa? Porque descobriu que ele estava com AIDS.

P: Nossa!

B6: Ele virou morador de rua.

P: E aqui no Brasil ainda, que é referência de tratamento para o mundo.

B1: AIDS não mata mais.

B6: A família botou ele para fora de casa.

B1: O que tem de mãe que bota o filho para fora de casa porque é gay.

B2: Parece que muda o quê o amor da mãe pelo filho? A opção sexual é dele. O que vai fazer o amor de mãe?

P: Você ia falar alguma coisa, A9?

B9: Eu tenho uma amiga que não ficou com um nordestino porque ele falava errado.

P: Meu Deus, eu sou professora. Conte-me mais.

B9: Sabe do que ele andava? De Hilux zero.

P: Ele tinha dinheiro, mas...

B5: No Camaro Amarelo.

B9: Ele tem um restaurante no XXX. Ele tem muito dinheiro e ela tinha vergonha dele porque ele falava errado.

P: O que essa sua amiga faz?

B9: Ela faz faculdade, nesse tempo ela já fazia faculdade. Ela trabalhava na Febem na carceragem, é.... 


\section{P: Agente penitenciária?}

B9: Agente penitenciária e ela fazia faculdade. E ela não ficou com ele por causa disso. Só gostava de andar na Hilux dele.

P: Isso eu ia perguntar. Será que ela não ficou com ele um pouquinho e tal?

B9: Ficou.

B3: Mas aí entra aquela revista tipo "Estilo". A pessoa que usa uma Hilux não tem o estilo. Não bate, né.

P: Por quê?

B3: Eu acho que no caso desse moço que tem a Hilux, ele está agindo mais pelo que a sociedade está exigindo e ele não está se reciclando, ou então que ele fale, mas que procure estar com pessoas do nível dele.

P: Como assim nível?

(Vários alunos falam ao mesmo tempo)

B5: É diferente de preconceito.

P: É, não é? Não estou dizendo preconceito, mas...

B5: Preconceito só porque fala errado.

B6: O cara tem dinheiro, tem tudo, o cara não entra numa escola para estudar?

P: É o que muita gente falava do Lula, por exemplo.

B2: Mas então, ela não podia ficar com ele e incentivar isso a ele? Essa menina não podia ficar com ele e incentivar ele a estudar, a aprender a falar?

B6: Por que?

P: Por quê?

B6: Porque nós queremos um lugar melhor na sociedade, um emprego melhor... ???? melhor. A empresa exige de nós

B1: Na verdade, a gente é que tem que se colocar na sociedade assim, se transformar no que a sociedade exige. Não é a sociedade que tem que se encaixar na gente; a gente é que se encaixa nela. A gente tem que estudar, aprender o máximo.

B6:Você tem...

B1: O quê?

B6: ....... você tem.

B2: Na sociedade...

P: Mas lembrem que a sociedade somos nós também. Então, será que a gente não pode questionar certas coisas?

B5: Pode.

P: Por exemplo, você não achou estranho a sua amiga ter deixado de ficar com o rapaz?

B9: Com certeza. Se fosse para mim, a resposta seria enorme. Falaria para ela assim, "Eu, para você chegar aonde eu cheguei, já tive que ralar muito".

P: Deixa eu perguntar agora para os rapazes. Independentes de serem casados ou não. A começar por você, B7, que levantou a questão e eu lembrei disso. Você ficaria, namoraria com uma moça que não tivesse dentes? Que fosse banguela?

B8: Comprava um para ela!

(risos)

P: O B8 já ligeiro!

B5: Aí, B8!

P: É, tirando essa opção que o B8 deu. Antes, de sugerir isso para ela.

B9: Se eu namoraria? Com certeza, não.

P: Por quê?

B9: Porque ela não tem dentes.

P: Por quê?

B9: Porque ela é banguela.

P: Por quê?

B8: Mas você vai beijar o dente ou a língua?

B4: Eu acho que... Na minha opinião, a pessoa pode ser banguela, a pessoa pode ser suja, ela pode ser limpa, se você gosta da pessoa...

B5: Quando você ama não tem feiúra.

(Vários alunos falam ao mesmo tempo)

B2: Você vai gostar de uma pessoa assim hoje em dia? Hoje em dia você vai gostar de uma pessoa assim?

P: Você vai querer ficar com a Macabéa?

B4: Eu ficaria. Ninguém nasce perfeito. Se Deus fez, nasceu, cresceu, caiu. Fazer o quê? Isso faz parte na vida, não é?

P: Gente, espera aí? Ninguém nasce perfeito, certo? 
B6: Mas a maioria das pessoas tem vergonha da outra. Não sai com uma pessoa banguela porque tem vergonha da pessoa banguela. Mas vai ver como aquela pessoa é carinhosa, vê se ela não é higiênica, vê se ela não sabe educar um filho. Vai ficar com uma pessoa que é bonitinha só?

P: Exatamente. Mas por que as pessoas dizem que uma bonitona como a Juliana Paes por exemplo é bonitona, é perfeita?

B4: Eu conheço uma moça que, coitada, ninguém dava nada para ela. Se você visse ela, ninguém dava nada para ela, porque ela conseguiu sozinha.

P: Ela foi atrás das coisas dela?

B4: Ela trabalhou, ela conseguiu porque foi rejeitada sempre. Foi sempre rejeitada pelas pessoas. Nunca conseguia arrumar um namorado, "Ah, porque você tem isso, tem aquilo, não gosto de mulher assim". Ela deu um chega para lá, mudou tanto. Só sei que ela mudou. Não importa o que ela fez no corpo dela, sei que ela está perfeita. Sabe igual aquela música lá da "Baba Baby"?

P: Da Kelly Key?

B4: (?)

P: B6, o que eu ia falar é o seguinte. O que eu perguntei para o B7. Essa questão de ser banguela. Na verdade, assim, ela perdeu essa pessoa, provavelmente...

B9: Você namoraria uma pessoa banguela?

P: Você joga para mim a pergunta! (risos) Eu vou dizer também que não, porque eu não sou hipócrita. Mas isso vem da outra pergunta que eu ia fazer, porque os nossos padrões de beleza estão baseados em algumas coisas que tem a ver com esse texto. Eu não estou fazendo essa pergunta porque eu quero polemizar. Não é isso. Eu quero entender como vocês pensam. E não é só por que vocês pensam, tem todo um debate para gente entender, pensar e olhar de um outro jeito as coisas. De onde vêm os nossos padrões de beleza? Por que a gente acha que a Juliana Paes e a Kelly Key são bonitas?

B1: Dinheiro.

B2: Hoje em dia com dinheiro, a mulher implanta dentes. Quantos artistas já puseram? Já são velhinhos de idade e implantaram todos os dentes?

B6: Eu mesmo já fiquei seis meses sem o dente da frente.

P: Como você lidou com isso?

B6: Eu coloquei um pivot que ficava implantado no céu da boca.

P: Ah, mas você colocou um pivot.

B6: Toda vez que eu ia tirar um barato, eu assustava todo mundo e "tchan!" (imitando a personagem Tião Macalé).

(risos)

P: Você tirava (risos).

B4: Tem umas pessoas que favorecem o corpo delas a cirurgia plástica. cirurgias ..... já fez? .... pode fazer o que bem quiser da vida, né?

B9: Quantas faculdades, uma só?

P: Uma só.

B9: A senhora namoraria um analfabeto de pai e mãe que falasse totalmente errado, totalmente errado, você que é professora?

B8: Que falasse errado, errado, errado?

P: É assim, olha. Tem várias pessoas que dizem isso, né, eu não sei. Eu estou falando isso meio que me defendendo. Mas assim, é difícil você conviver em espaços que essas pessoas frequentam, então seria muito pouco provável que eu conhecesse, mas se eu conhecesse aí... “é o amor” (imitando a entonação da canção popular) é diferente.

B9: Mas a senhora formada. Vamos supor, a senhora tem o seu pessoal.

P: É, tenho os meus grupos.

B9: Você levaria ele? Sabendo que ele fala errado?

P: Aí, inclusive eu já sofri esse preconceito com meu marido porque ele é nordestino, por isso que estou falando dessa questão. Minha família também é nordestina e passa por isso. Ele é formado, tem uma história muito parecida com a minha, inclusive, e fala errado de vez em quando. Esse errado que a gente chama, né. Que não é errado, é fala popular. Apesar de ter passado pela faculdade, tem coisas que ele tem que ficar pensando antes de falar, algumas letras, o 1 e o r, por exemplo. Ele sofre um certo preconceito, às vezes.

B8: Eu sou de Minas, ela é de Minas. Quando nós chegamos aqui falando muito errado ainda. Só que a gente tenta se corrigir, para não passar um...

P: Para não passar um preconceito.

B8: E mesmo assim tem hora que você fala algumas coisas e tem gente que fala, "O que que é isso?"

P: Não é uma palavra errada, é uma palavra que se usa, um regionalismo.

B8: Eu contratei um funcionário uma vez lá na empresa que era analfabeto. Ele falou, "Sou analfabeto, não sei ler, não sei escrever nada". Só que a história dele me comoveu. E eu falei com o diretor, "Preciso contratar esse 
cara”, e aí, "O rapaz é assim, assim, assim”. "Não , não, esse cara só vai dar prejuízo". "Dá essa chance para ele? Se não der certo, depois de três meses, manda ele embora. Tem noventas dias para ver o trabalho dele". Colocamos ele dentro de um depósito de louça, bacia essas coisas. Falei, "Você vai tomar conta aqui, você vai limpar". O cara começou automaticamente a decorar a cor com o nome das louças. O pessoal falava, "José, louça tal! A cor tal, tal!”. Ele, “Tá ali!” Ele decorou e começou a deixar o depósito um brinco. Aí, automaticamente, o diretor viu isso e falou, "Por que a gente não libera ele um pouco mais cedo para ele começar a estudar?". É, legal. Ele começou a entrar seis horas da manhã, sair às quatro, ir para a escola, estudava duas horas na escola, seis horas ia embora. Aprendeu a ler e a escrever. Aí, um tempo atrás me ligaram, "Olha, vou mandar o fulano embora porque ele está escrevendo pelas paredes".

(risos)

P: Ué?

(risos)

P: Olha, gente!

B5: Não é piada não?

B8: Não é piada.

P: Mas parece piada. Que história!

B8: Parece piada, mas não é. Falei com ele, "O que aconteceu?" "Eu escrevo umas coisas nas portas, aqui tem louça. Eu gosto de escrever. E acharam ruim”.

P: Não deram um caderno para ele.

B8: "Aí foram falar comigo. Eu fiquei bravo, respondi para o chefe". Aí eu fui lá, troquei uma ideia com ele e com o cara do setor, mas o cara perdeu o emprego.

(risos)

B2: Ele gostou tanto de escrever que saiu escrevendo.

P: Ué, criança não faz isso?

B8: Mas agora eu falo uma coisa a você o que é o preconceito. Se ele não conta a história dele, ferrou. Ele morava mal, morava numa casa debaixo de um viaduto num córrego, quando dava enchente, não tinha para onde correr, os vizinhos precisavam socorrer, entrava rato... Ele contando a história, nossa, assim... O cara falava, a lágrima descia.

B4: Mas isso é interessante. A pessoa que já sofreu, já passou um período, você precisa ouvir aquela pessoa...

P: Exatamente, A4.

B8: Sabe o que o diretor falou para mim sobre a entrevista do rapaz? Coração é enganação.

P: Ah, meu Deus. Isso, num nível micro. Quer ver? Fala de novo para a gente, A4, que isso é um exemplo da vida.

B4: O que a pessoa passou na vida, já passou. Mas para entender aquela pessoa, justo agora, tem que saber o que aconteceu com aquela pessoa.

P: Dar ouvidos para essa pessoa. O que acontece no nível micro que você está falando, com uma pessoa, a história de vida de uma pessoa é o que acontece na história de milhares de populações de pessoas no nível macro. É quando você não dá ouvidos para as pessoas. Os preconceitos nascem assim.

B8: É, isso tem a ver com a injustiça.

P: Assim são as injustiças. É assim mesmo.

B4: Tem alguns lugares também...

P: Ah, não! Não vou te ouvir! Eu construo a sua história! Eu já sei a sua história! Ah, por quê? Porque todo brasileiro gosta de ficar sambando na rua. Não sei, não conheço o Brasil. Eu nunca dei ouvidos ao Brasil. O que eu sei é que... Brasileiro? Brasileiro é malandro e samba na rua.

B8: Eu já fiz isso, professora. De pegar e tomar uma decisão sem olhar a pessoa. Até o dia em que eu bati a cara e descobri que eu estava errado. Os funcionários chegavam, eu peguei bronca daquele cara, "Quando ele chegar atrasado, vai voltar para casa". Até o dia que me pediram para mandar uma pessoa embora. "Vou mandar fulano! É esse!"”.

P: É esse mesmo!

B8: Aí a pessoa chegou e falou assim, "Antes de você mandar ele embora, por que você não senta para conversar com ele algum dia, por que está chegando atrasado?". Falei, “Olha, vou conversar por conversar mesmo". Sentou na minha frente para contar por que chegava atrasado, o objetivo (?). Ele tinha uma filha com leucemia que ele levava no hospital para tomar sangue, entendeu? O homem vinha correndo a pé para chegar no serviço, chegava atrasado e eu mandava para casa.

P: Se você não conhecer a história...

B8: Esse cara é hoje um dos supervisores gerais da loja.

P: Isso tanto assim, sobre a história das pessoas, quanto todo tipo de informação. Quando a gente não tem acesso a diversos tipos de informação...

B8: Informação de tudo hoje em dia. 
P: É. A gente está mais suscetível a cometer erros, né. Sim? Bom, vamos voltar para o texto? Lembrando... Esse narrador está disposto a dar voz para esta personagem, não é? Quer contar a história desta personagem, ele acha que é importante que todos saibam a história dela. Daí, já ligamos com isso que você falou. Tem que dar ouvido para a pessoa, essa pessoa que sofreu, que tem muitas coisas para contar. E a gente muda também o nosso ponto de vista sobre ela. Ok? E. , a gente está no terceiro e último parágrafo.

B9: "E assim se passava o tempo para a moça esta. Assoava o nariz na barra da combinação. Não tinha aquela coisa delicada que se chama encanto. Só eu a vejo encantadora. Só eu, seu autor, a amo. Sofro por ela. E só eu é que posso dizer assim: 'que é que você me pede chorando que eu não lhe dê cantando'? Essa moça não sabia que ela era o que era, assim como um cachorro não sabe que é cachorro. Daí não se sentir infeliz. A única coisa que queria era viver. Ela pensava que a pessoa é obrigada a ser feliz. Então era."

P: Digam vocês, que eu já falei demais.

B3: A pessoa tem um comportamento que para ela, ela é feliz assim.

P: Porque ela era obrigada a ser feliz. Porque ela nunca pensou sobre isso, na verdade, né?

B3: Nós somos nós outros e ela seria feliz daquele jeito. O mais importante para uma pessoa viver é ser feliz.

P: Será mesmo?

B3: Sim.

P: Será que o mais importante na vida de alguém é ser feliz? Quem disse isso?

B3: Isso aí não precisa dizer.

B1: Os contos de fada.

P: Os contos de fada! A novela! São muitas histórias que a gente escuta. Lógico, não estou dizendo que não é para ser feliz, mas tem tanta coisa que a gente precisa fazer para viver, né. E isso é uma coisa que ela nunca questionou, certo? Porque, se ela questionasse ela ia... Meu Deus! (finge que está desmaiando). E agora? Ela ia tomar um susto na vida dela. Mas existem muitas coisas que poderiam modificar, inclusive, a condição dela.

B3: A análise disso aqui é a análise do comportamento da mulher. A outra agradeceu a menina por ter roubado do marido. "Obrigado, eu me sentia melhor como era, e não como estava a sociedade hipócrita".

B9: (?)

B1: Era simples. As pessoas aconselhavam, "Você tem que se comportar agora como uma dama, uma esposa!" "Não, mas eu gosto de dançar". "Mas você não pode dançar!"

P: O rapaz da Hilux, lá!

B3: (risos)

P: Não é? Tem coisas que seu estilo condiz? Ou não condiz?

B3: Você tem que ir modelando.

]

B2: Você tem que ser jeito do que é. Existe muita coisa para ser feita.

B3: Do jeito que é vai dependendo do seu desenvolvimento

B8: Vai depender do seu estágio.

P: Bom, gente. O que vAocês acharam dessa leitura?

B1: Boa.

B2: Bom seria se tivesse o livro nessa biblioteca.

P: Não tem? Vocês já procuraram esse livro?B3: Eu já procurei.

P: Gente! Esse livro é um livro maravilhoso.

B3: Aí, aí, não tem nada.

P: Vamos ver! Não tem biblioteca aqui perto?

B3: Tem. Não tem nada lá.

P: Não tem? Gente! "A Hora da Estrela” é um livro que muda a vida das pessoas. Vou conversar com a Vívian sobre o que a gente pode fazer.

P: Bom, pessoal. Além da leitura da Lispector, que claro, literatura é assim, o autor diz muitas coisas e a gente fica lendo nas entrelinhas. Eu já li esse livro umas quatro vezes. É verdade, já li umas quatro vezes.

B3: Por que você leu quatro vezes o livro?

P: Porque eu acho maravilhoso e cada vez que eu leio eu vejo de um jeito diferente. Só esse trecho que eu li junto com vocês já foi diferente de quando eu li quando vocês estavam tendo aula com a Vívian e eu lá folheando já li de um outro jeito que eu estou lendo agora com vocês, por exemplo.

B3: Leitura dinâmica.

P: Não. Eu já conhecia, mas eu notei agora sobre o preconceito porque eu li com vocês. Vocês me contando as coisas já me deram muitas outras ideias que eu não tinha visto antes. Eu já tinha visto neste trecho, sabe, que o narrador ele troca o ponto de vista nos parágrafos. Isso eu já tinha percebido. Mas quando você lê com cada pessoa dando sua opinião é mais rico, eu acho. Muito mais. Eu acho, né. Não sei vocês. O que vocês acharam dessa discussão que eu tentei colocar para vocês?

B3: Maravilhosa!

P: Obrigada pela participação. 


\section{Apêndice 10 - Entrevista com Vívian em 09 de novembro de 2012}

P: O psicólogo deu algum tipo de orientação pra vocês

V: Ele veio orientado por todos nós. Foi assim: sempre no final do ano, ontem foi uma dessas reuniões, a gente faz uma reunião de avaliação do PEA. O PEA é o que a gente faz nos horários coletivos. A gente se reúne pra fazer os nossos planejamentos. O PEA é formação pra nós. Então no PEA a gente tem reunião de conteúdo, teorias, estudos pra gente poder trabalhar com o aluno depois. Tem também o PVS, o coletivo, que a gente se reúne pra fazer o planejamento dessas vivências semanais.

P: Isso tudo com a equipe do Centro Educacional Trandisciplinar?

$\mathrm{V}$ : A equipe toda, todos os professores, todos unidos, todos juntos. E nessas reuniões a gente faz planejamentos, a gente lê textos.

P: Esses textos, quem escolhe?

V: A nossa coordenadora. Por exemplo, ontem foi esse da Martha Medeiros. Ou a XXX, ou a XXX, que se aposentou semana passada. Ontem nós lemos o "Não desista nunca", da Martha Medeiros e aí no meio das reuniões a gente conversou a respeito do que nós gostaríamos que tivesse do PEA para o ano que vem. Então, sempre de um ano para o outro nós mesmos damos algumas sugestões. E as coordenadoras também têm ótimas ideias, ótimas sugestões. A gente junta tudo, as coordenadoras fazem uma panelada desses conteúdos, ideias, livros, bibliografias que a gente queira ler, estudos que a gente queira fazer, autores que a gente queira estudar, e ela acrescenta o que está aí no meio cultural e no meio educacional. A gente trabalha tanto com cultura geral quanto com cultura educacional, a parte mais pedagógica, didática do ensino, história da educação e a gente faz estudos aqui para a gente se atualizar, para se manter atualizado. E agora a gente tem os livros de Orientações Curriculares. São livros que tem especificamente de cada disciplina, que a prefeitura mandou.

P: Mas é só do Centro Educacional Trandisciplinar ou são os livros oficiais. Inclusive estão disponíveis na internet, não é?

V: Isso. São os livros oficiais, disponíveis na Internet. Têm pra todas as escolas municipais. E as escolas de EJA, agora ganharam um especial para EJA, no ano passado. Especial pra EJA. Esses livros de orientações têm orientações Curriculares, de conteúdo de currículo, sugestões. Inclusive, a W.

P: Escreveu...

V: Escreveu o de Inglês.

P: Foi assim que eu comecei a saber que tinha orientações só para EJA, que não é uma coisa tão geral assim.

V: Era geral, agora tem o específico para EJA. Começou o ano retrasado, em 2010 se eu não me engano. Em 2009, 2010 que saíram essas orientações e o ano passado surgiram esses livros de EJA que agora a gente usa, antes não tinha. A gente tinha que usar livros de curso regular e não tinha tempo hábil e não era a cara deles. Era fotinho de criancinha, era coisa que não tem a ver com a realidade deles. E agora eles têm livrinhos próprios, quer dizer a EJA está sendo valorizada.

P: Por que será?

$\mathrm{V}$ : O interesse nessa valorização? Eu acredito que por tanta cobrança nossa, porque, poxa vida, tem gente que não conhece o Centro Educacional Trandisciplinar. Então, é pouca propaganda...

P: Quando começou, em que governo foi?

V: Puxa, agora você me pegou...

P: Porque eu escutei os professores, não, o...

$\mathrm{V}: \mathrm{O}$ B.

P: Ele estava me contando que ele está aqui há doze anos. Mas será que é desde o começo do _Centro Educacional Trandisciplinar, ou não.

V: Esse Centro Educacional Trandisciplinar eu lembro que é o seguinte: a F. sabe contar para você direitinho a história.

P: Quem é a F.?

V: A F. é a professora nossa do coral. Ela é professora de Linguagens e Códigos, é a mais antiga aqui e ela sabe contar direitinho, inclusive. Então, antes de ser Centro Educacional Trandisciplinar aqui, esse prédio era usado como CEMES, não me lembro muito bem a sigla. CEMES eram também escolas de Jovens e Adultos. Só que era apostilado, era um curso um pouquinho diferente, ele era à distância. Tipo à distância, vai...

P: Então os alunos vinham até a escola para fazer o quê, as avaliações?

V: Para fazer avaliações e pegar orientações. Então os alunos tinham a apostila, umas apostilinhas para cada disciplina e os professores faziam estudos para essas disciplinas. $\mathrm{O}$ estudo era interdisciplinar e polivalente, o professor dava aula de tudo. Então, como funcionava, toda sexta-feira, os professores... eu não sou dessa época... P: Eu já ia perguntar, nossa...

V: Não, faz vinte anos. Há vinte anos, mais ou menos. A F. que conta... De sexta-feira eles faziam encontros, reuniões, ficavam a tarde toda da sexta-feira se formando, um ensinando para o outro e dessas reuniões eles decidiam os conteúdos do PVS, a mesma coisa que a gente tem hoje em dia, Plano de Vivência Semanal, da 
semana seguinte. Nesse dia não tinha aula com os alunos. E aí nesse dia de formação eles trocavam ideias, faziam reuniões com a coordenadora e com a diretora, avisos, igual a gente tem hoje em dia. Só que hoje em dia nós temos dois dias, terça e quinta à tarde. Esses dias podem mudar. Ano que vem talvez a gente escolha outros dias da semana. E nesses dias de formação não tinha aluno na escola, era o dia que os alunos faziam as lições em casa. Durante a semana eles vinham cumprir algumas horas na escola e algumas horas em casa. Igual é hoje, hoje em dia são duas horas e quinze na escola mas eles têm que complementar com atividades em casa. Essas atividades entram no nosso diário como atividade extra. Então a gente tem no nosso diário além da parte normal de conteúdo e chamada, tem a parte que a gente chama de atividades extra-classe. E aí a gente vai colocando positivo ou negativo, a gente chama de cemitério porque tem um monte de cruzinha, né.

P: Pra ter controle do que foi feito, né.

V:. Exatamente. Eu estou pedindo aí duas atividades extra-classe, uma redação e os brinquedos, por exemplo.

P: Então isso não é nota. Isso é hora-aula.

V: Isso, porque ele produziu esse brinquedo e essa redação fora de aula. Aí a gente faz um planejamento do que teve, discriminar..

P: Quantas horas vão valer, inclusive?

V: São sessenta horas por semestre. Então a gente tem sessenta horas-atividade. A gente calcula, por exemplo, que ele demore uma hora na redação. Ou três horas no brinquedo. Faça uma visita à biblioteca que demore uma hora, assista a um filme que demora duas horas. Faça um passeio cultural com a gente, tem dias que é com a gente, que vale mais tantas horas depois para ele fazer uma resenha ou relato dessa apresentação - hoje tem, hoje nós vamos visitar a Bienal de Arte lá no Ibirapuera. Além de tudo isso, cada professor de cada área faz um desse. Para Linguagens e Códigos são sessenta horas, para Ciências da Natureza são quarenta horas. E EP (Ensino Profissionalizante) é pouquinho, acho que são vinte horas por semestre. Além disso tem as notas deles. Cada professor faz a avaliação que ele quer. Por exemplo, a professora G. faz quatro avaliações. Eu já sou meio chata. P: São mais avaliações, ou avaliações mais complexas, como assim chata?

V: Não, é que eu gosto de avaliar detalhes. Eu sou meio detalhista. Mas aí cada um faz quantas quer. Eu fiz um monte. A avaliação depende de cada professor, essa avaliação é extra. Mas as atividades devem ser as mesmas.

P: Tem que fazer igual, as mesmas atividades para todos os professores de Códigos?

$\mathrm{V}$ : Os professores combinam no começo do ano, fazem um planejamento. "O que dentro do nosso conteúdo que serve como extra-classe? O que vamos pedir como lições de casa?”. E tem coisas que surgem no caminho também.... Estavam com problema de cedilha, misturavam o cedilha com o cê. Então vamos dar umas atividadezinhas de jogos de palavras, recorte de palavras, formação de frases, caça-palavras com cê cedilha? Vamos. Agora, tem coisas que a gente planeja, por exemplo, vamos fazer pintura, então vai precisar fazer pesquisa sobre Monet. Nesse ano foi sobre o Arcimboldo, Cézanne e o Pollock. Tudo isso é planejado nessa hora coletiva, nesse PVS.

P: Quanto tempo por semana vocês têm para essas reuniões?

V: Quatro horas semanais.

P: Legal.

V: É muito bom, é muito rico.

P: Então é por isso que a escola não tem nenhum aluno à tarde? Mas vocês estão aqui trabalhando.

$\mathrm{V}$ : Exatamente, de terça e quinta.

P: Vívian, primeiro eu queria começar perguntando sobre a sua formação e a escolha de trabalhar com educação pública e no Centro Educacional Trandisciplinar. Eu estou até curiosa sobre a sua formação porque você tem que ensinar Cézanne, essas coisas, eu não teria como ensinar essas coisas.

$\mathrm{V}$ : Mas eu também não tenho (risos)

P: Como que você...

V: Formalmente e informalmente também...é muito importante. Formalmente eu fiz o magistério. Não é todo professor daqui que tem magistério, eu tive essa oportunidade. Eu fiz os quatro anos de magistério aqui no XXXXX, muito bom. Olha, agradeço muito ao magistério em muitas dicas. Por isso até que eu consigo até com o processo. Lógico que a gente cresce ao longo da vida, mas esse conhecimento a respeito de alfabetização, essa paciência que a gente tem que ter com os alunos. Com esses alunos especiais, eu agradeço muito ao meu magistério, devo muito a ele e todo o conhecimento em Pedagogia e Didática. Não tenho Pedagogia, não fiz Pedagogia, eu fui direto fazer faculdade de Letras. Em Letras eu estudei na Universidade XXXX. Passei na USP, mas...

P: É, como é essa história de você não ter podido estudar na USP?

$\mathrm{V}$ : Quando eu passei na USP eu trabalhava, eu precisava do dinheiro.

P: O que você fazia na época?

V: Eu trabalhava como professora de Fundamental I.

P: Com a formação do Magistério você já podia trabalhar no Fundamental I.

V: Já podia. Hoje em dia eles exigem uma faculdade. Qualquer uma, não precisa ser Pedagogia, mas exigem uma faculdade. Quem tem Magistério tem que fazer uma faculdade também e quem não tem vai fazer um 
colegial normal e vai fazer Pedagogia para dar aula de Fund I. Essas meninas estagiárias nossas do andar de baixo (onde são ministradas as aulas de Fundamental I) são todas...

P: Alunas de Pedagogia, né.

V: Alunas de Pedagogia. E aí eu fiz Magistério, dava aula pra criançadinha pra pré-escola, de primeira a quarta série eu pegava algumas aulas no Estado. Trabalhei dois anos como eventual nas escolas do Estado e trabalhei uns três, quatro anos dando aulinha pra criancinha pequena em escolinha de Educação Infantil particular. Quando eu comecei a fazer Letras, começaram a me chamar para dar aula de Inglês. Eu posso falar a verdade, eu odiava Inglês (risos).

P: É mesmo?

$\mathrm{V}$ : Não é que eu odiava...

P: Por quê? Você começou a fazer Letras, você já tinha estudado Inglês antes ou não? Por que você odiava?

$\mathrm{V}$ : Nada... Eu odiava porque na escola eu achava as professoras de Inglês muito exibidas. Eu falava "Nossa, não estou entendendo nada!" e elas chegavam falando Inglês. Nós não tivemos Inglês da primeira à quarta série porque eu sempre estudei em escola pública. Então na quinta série quando eu comecei a ter Inglês foi o ano em que meu pai pôde pagar uma escola para nós, ele estava melhorzinho de vida, por isso ele pagou para mim e para duas das minhas irmãs. Nós somos em quatro. E aí ele pagou escola particular e a gente começou a ter Inglês.

P: Daí, o gap porque seus colegas já estudavam desde a primeira série.

V: Exatamente. Particular eles têm desde o pré. Poucas coisas, mas eles já tinham conteúdo. Eu sei que eu cheguei na quinta série zero, nada. E aí meus amigos já sabiam, mas tudo bem. Mesmo assim eles também estranhavam. Eu lembro que eles não sabiam muito, quase nada, vai. Eles sabiam cores, números. Mas eu levei numa boa, eu tirava só dez. Eu era bem dedicada, eu estudava pra caramba. Mas eu não conseguia falar nada em Inglês, nada. Eu lembro que a professora era superlegalzinha só que tinha isso, ela falava blablablablabla pra mim era blablablabla, eu não entendia nada. E aí ela parava, explicava a gramática em Português pra nós, foi o que me salvou. E eu gostava de Português.

P: Por isso você fez Letras?

V: Por isso eu fiz Letras. Por causa de Português. E nossa, eu não entendia nada. Eu sei que eu fazia as atividades assim, eu olhava e via que tinha exemplos, né. A nossa época era a época dos exemplos. Então você tinha o exemplo e você seguia o exemplo. Então era mais fácil. Eu comecei a analisar através dos exemplos e fazia meio que sozinha. Os professores não davam atendimento individual. Não tinha esse paternalismo e esse "maternalismo" de hoje em dia. E tradução de texto. Foi essa minha história cultural de Inglês. Tradução de texto e esses exemplos que você que você tinha pra gramática. Então você tinha a explicação, às vezes um dialogozinho, você tinha que comparar porque a professora explicava em Inglês. E aí você tinha que comparar e começava a perceber, “Ah, aqui é does, aqui é do, por que meu Deus? Por quê?” Eles começavam a explicar. Aí a professora vinha e dava um toque. "Então, pessoal, como vocês começaram a perceber, eu vou passar uma explicação em Português", e isso salvava a gente. Aí eu lia, lia, lia até entender, em casa ficava lendo até entender, porque minha mãe não manjava nada de Inglês, meu pai também não, então... E pegar dicionário e começar a ver que no dicionário tinha umas coisinhas lá esquisitas, aí eu olhava no começo e via que aquilo era uma explicação, aquilo era o som da palavra. Aí eu comecei a entender um pouquinho de sonoridade. E a tradução, e aí você via milhares de traduções e você começava a ver, "ah, a professora pôs só uma, por quê? Porque é a que mais se adapta”. Então tinha coisas que a gente tinha que perceber.

P: Porque ela não ia contar pra vocês.

V: Porque ela já tinha explicado isso, não é maldade dela, nem nada.

P: Ah, entendi.

V: Ela já tinha explicado. De primeira a quarta série todo mundo já sabia fazer isso. E muitos de nós que começamos na escola particular na quinta série não tínhamos essa base. E aí aos pouquinhos, eu morria de vergonha eu era a mais quieta da sala, eu era do fundão, nem dá pra acreditar hoje em dia, né. Eu era muito alta, eu tinha vergonha de meu cabeção atrapalhar os demais.

P: (risos)

V: Eu sempre sentava no fundo, mas eu tentava escutar, prestar atenção e tentava me dedicar. Bom, assim foi. Aí comecei a traduzir melhor, com muita dificuldade, mas ia caminhando. Então eu sabia conteúdo de quinta a oitava. Quando eu entrei na faculdade era isso. Quando eu entrei na faculdade...

P: Porque no Magistério você não teve Inglês?

V: Nada, não teve. Inclusive no Magistério minha professora de Inglês, tivemos só um ano. No colegial eles têm três anos, né. Ah, esqueci de falar do Magistério. No Magistério a gente teve um ano só, mas minhas amigas não sabiam nada quase de Inglês porque estudaram em escola estadual. E eu tinha feito de quinta a oitava na particular, então eu ajudei muitas das minhas amigas. Foi legal porque eu melhorei no Inglês ajudando elas e comecei a gostar de ensinar Inglês. Elas não sabiam nem o que era he nem she, nada.

P: Mas teve uma época também, inclusive quando eu entrei na quinta série (que o Inglês deixou de ser disciplina obrigatória nas escolas estaduais)... Elas não tiveram aulas de Inglês ou a aula de Inglês era o verbo to be?

$\mathrm{V}$ : A aula era mais fraca. Era o verbo to be. 
P: Teve uma época, eu lembro quando eu entrei na quinta série não tinha aula de Inglês. Eu só passei a ter na sexta série. Eu estudei em escola estadual. Quer dizer, o governo tirou as aulas de Inglês em certo período.

V: Vai ver foi igual Filosofia, que tiraram.

P: Exatamente.

V: Sociologia agora voltou, você viu? Às vezes, dependendo do governo as políticas têm interesses.

P: Exato. Inglês está com tudo agora. Por quê?

V: Com Copa e Olímpiadas no Brasil, estão também investindo no profissional. Nem livro de Inglês tinha na escola. Tinha livro de Português, Matemática, História e Geografia. Arte, nunca teve.

P: É verdade, Arte é uma matéria também que...

V: Sempre foi deixada de lado. Inglês, Educação Física... agora tem livro também.

P: Nossa, que legal.

V: No Estado tem livro. Na Prefeitura ainda não, mas no Estado já tem livro de Educação Física. Então, depende da política, do governo da época,

P: Então, você ensinou suas amigas no Magistério, melhorou bastante o Inglês...

$\mathrm{V}$ : Nossa, melhorei pelo menos a gramática, melhorei a escrita.

P: A fala ainda não.

V: Não, porque não era cobrado. Aí eu comecei a falar um pouquinho porque quando eu entrei na XXXX faculdade de Letras, eu tive que optar por Inglês porque só tinha Inglês e Espanhol. Eu passei na USP e eu estava querendo aprender até Francês. Eu estudei Francês, Alemão e Italiano no XXX ${ }^{50}$. No XXX onde eu estudei tinha Francês, Alemão, Italiano e Espanhol. Aí eu pensei, "Vou estudar Espanhol pra quê? Dá pra entender!". Olha a minha ideia... Pensei "Vou fazer uma língua diferente, vou fazer Francês" e amei. Eu adorava minha professora a XXX, um amorzinho. Aí enganchei depois Alemão, só que Alemão não dá pra aprender tanto porque ele é muito diferente. Ela não é uma língua latina, ela é uma língua do ramo do Inglês. Ela tem muito do Inglês e muito do Latim, como as declinações, o dativo, o acusativo, nominativo do Latim. E aí eu me formei em Alemão, mas falo que eu não sei tanto falar em Alemão quanto eu sei em Francês. Comecei o Italiano, mas eu tive que parar por causa da faculdade. Já não dava mais pra conciliar os horários, fiz um ano e meio, só três módulos. Agora, o Inglês... Então, eu fiz essas línguas quando eu estava no Ensino Médio. Eu tinha quinze, dezesseis anos. Aí eu fui meio que forçada (risos) a fazer Inglês, mas eu falei "Pô! Se eu ensinei para as minhas amigas, por que não tentar? Vamos lá...” E o Inglês da minha faculdade era bem complexo. A professora de História da Língua Inglesa só falava Inglês. Só que ela só falava em Inglês, não tinha gramática para ela explicar em Português, só Inglês. Eu juro que eu ficava assim... quase querendo chorar.

P: Por que não conseguia entender o que ela falava, por que sua única base de apoio era a gramática, né?

V: A minha professora de Gramática, maravilha. Nossa! Aí eu também ajudava as minhas amigas em Gramática. E a parte de oralidade, eu tinha duas ou três amigas que manjavam, que faziam curso de Inglês em escolas de idiomas, e outras mais, então elas me ajudavam. A gente trocava ideias. E tinha uma professora de laboratório, especificamente de laboratório. Só que ela tirou licença naquele ano porque ela ficou doente. Nós ficamos um tempão sem professora de Inglês. Eu sei que eu tive pouquíssimo Inglês falado, assim, pra gente treinar a nossa fala. Tivemos uma professora ótima de História da Língua Inglesa, de Literatura Inglesa e essa professora de Literatura Inglesa era ótima. Ela só falava Inglês. Era bom pra gente escutar, algumas palavrinhas, a gente acompanhava pela apostila e tudo em Inglês, tudo tudo tudo. E tínhamos a professora de Gramática da Língua Inglesa que dava aula específica de Inglês. Aí eu comecei a me familiarizar e me chamaram. Eu mandei currículo para escolas, me chamaram para dar aula de Inglês no XXXXX. Sorte que era para criancinha. Ah, mas eu amei. Foi aí que eu comecei a deslanchar de falar Inglês, com a criançada. Com a criançadinha, você tinha mais liberdade.

P: Quer dizer, você já tinha trabalhado com crianças, ensinando outras coisas, porém o ambiente é o mesmo.

V: Sabe, era coisinha simples. Tinha que ensinar para eles o quê, cat, dog, animaizinhos, numbers, one, two, three, four, five... Eu falava tree na época, igual árvore, né... (risos) Aí depois eu comecei a diferenciar o tree do three... e aprender esse th e tal... Aí eu falei, "Poxa, vou fazer um curso". Aí, eu fiz XXX. Então eu fazia XXX, dava aula para as criancinhas e fazia faculdade à noite. E continuava no Estado dando aula como eventual no Fund I. E... depois eu parei um pouquinho porque eu peguei muitas escolas particulares, curso de Inglês, muitas muitas muitas, dando aula de Inglês pra criançadinha do maternal, jardim I, jardim II e pré. Aí, maternal, jóia, eu adorava fazer recortes e colagem. Por exemplo, hoje aprendeu cat, fazia um cat de dobradura pra eles, fazia atividades e eles levavam pra casa, então eu trabalhava muito com o lúdico. Comecei a aprender violão nessa época. Nossa, eu tocava mal.

P: Pra poder tocar, ou por outras coisas, assim?

V: Não, pra poder tocar com as crianças. Com uns quinze anos, eu comecei a frequentar a igreja. E na igreja eles precisavam de alguém pra tocar órgão pras crianças da catequese. E não tinha ninguém. Aí meu pai, olha meu pai me fez passar uma vergonha... Só que graças a ele eu toco hoje. "A minha filha gosta de música. Vou ver se

\footnotetext{
${ }^{50}$ Centro onde cursos de línguas oferecidos gratuitamente para alunos de escola pública.
} 
ela aprende. Vou pôr ela na escola”. E meu pai me pôs na escola de música. Aí eu comecei a tocar órgão. E toco até hoje, faz dezoito anos que eu toco órgão na igreja. Mas não dá pra levar o órgão pra sala de aula. Aí fazia instrumento de bandinha de feijão, copinho de iogurte, a gente fazia na escola com os professores e a gente cantava, tal. Aí eu falei com um amigo da igreja, o R., "R., eu ensino pra você órgão e você me ensina violão". Então eu aprendi assim. Eu não toco muito bem, mas dá pra quebrar um galho. Comecei a pegar revistinha. Hoje em dia com a internet dá pra aprender também. E fui aprendendo a parte musical. Gostava muito de cantar com a criançadinha. Fiz curso na ULM também, a Universidade Livre de Música, aquela que é de graça, na Luz. E nessa época eu estudava muito, todo dia, toda hora eu tinha aula de alguma coisa.

P: É, eu fico imaginando. Quem aprendeu três línguas na adolescência...

$\mathrm{V}$ : Eu sempre gostei de estudar bastante. Eu não tenho uma boa memória, não. Eu faço associações pra eu memorizar as coisas. Que nem, você P, eu decorei pela outra P, seu nome. A gente vai fazendo associações. Mesmo as palavras, eu tinha dificuldade. Mas eu lembro que eu necessitava do básico. Então, já que eu necessitava do básico, uma vez um aluninho perguntou "Professora, como é rinoceronte?", e eu "Não sei, vamos ver no dicionário?". Nunca tive vergonha de falar "Não sei, vamos buscar". E a gente pegava o dicionário e via, aprendia palavras novas. A criançadinha de pré nem pergunta, mas a partir da primeira série, que eu comecei a dar aula de primeira a quarta série lá no XXXXX, eles perguntam mais. E aí, começaram a ter livros, e os livros tinham coisas que eu não sabia. Eu não sabia coisas de primeira a quarta de escola particular.

P: Mas também você estava estudando Inglês no XXXX, eles não iam te ensinar nome de bicho nunca.

V: Tudo, exato, você entende? É outro foco. E assim, nome de bicho, e vocabulário assim, coisas como telhado, que eu nunca usava, mas que tinha que usar de primeira a quarta. Aí eu ampliei esse vocabulário basicão e lá no XXXX eu aprendi a falar e a perder a vergonha de me comunicar com os demais. E foi isso, terminei o curso do XXXX, fiz até o High Advanced, mas tive professores que falavam só Inglês, tive professores que falavam mesclado. Tive uma professora que dava aula também em escolas particulares, ela era mais didática. Então, eu fiz muito essa mistura de práticas do Inglês.

P: E sobreviveu à faculdade.

V: Sobrevivi à faculdade (risos). Literatura, não tirava boas notas não. Tirava cinco, seis, sete... E eu gosto de livros, eu amo ler. Agora, você perguntou daí em diante.

P: Sim. Educação pública e Centro Educacional Trandisciplinar.

V: Então eu passei a ensinar não só Português, passei a ensinar Inglês pros meus alunos do Estado. Não tinha Inglês.

P: Você não é eventual de Inglês ou de Português, você é eventual [de todas as disciplinas].

V: Você é eventual. Você tem um projeto. Então, com os pequenos eu tinha um projeto de teatro e música, porque eu gosto muito. Sem formação... quer dizer, quando era pequena, com uns doze anos de idade, antes de começar o curso XXX, eu fiquei sabendo que na biblioteca da XXXX, imagina que meu pai ia poder pagar essas coisas pra mim, né... Tinha a Casa de Cultura da XXXX.

P: No Teatro XXXX?

$\mathrm{V}$ : Exatamente.

P: Tem vários cursos lá, né.

V: Fiz vários cursos lá.

P: Mas não é curso de formação de atores, são oficinas, né.

$\mathrm{V}$ : Workshops e oficinas.

P: Você foi fazendo um atrás do outro, de vários temas diferentes?

V: Eu fiz, por exemplo, primeiro Expressão Corporal. Pra mim foi muito bom porque foi a época em que eu comecei a me mexer mais. E aí entrei no Magistério e lá você tem que fazer o quê, tem que dar aula. Nossa, eu morria de medo de dar aula. Pra muita gente, né. Medo de errar alguma coisa, de não ter a atenção deles. É difícil você obter a atenção deles. E fazia muita palhaçada pra isso. Essa coisa de fazer brincadeiras, de me soltar mais foi da época da Casa de Cultura da XXX. Fiz Expressão Corporal, fiz Palhaço em Cena, fiz workshops de piadas, até. E essa formação, ela vem daí. De muito cursinho, da frequência na igreja. Acho que a igreja também me ajudou. Porque muitas vezes os meus amigos falavam, "Vívian, você ensaia o coral?" e eu "Bom, gente, vamos ensaiar, como que é, como funciona? Vocês pegam a música e trabalham em cima? Então beleza. Eu vou tocar e vocês vão cantando, porque eu não consigo fazer as duas coisas ao mesmo tempo". Eu estava começando a aprender a tocar órgão. E assim eu fui pegando mais prática de trabalhar com o público, essas coisas me ajudaram bastante. Graças a Deus, quando eu comecei a dar aula de quinta a oitava na prefeitura e no Estado. No Estado não, no Estado eu estava me acostumando, eu pegava como eventual, só que os alunos gostavam de mim porque eu chegava sempre com novidade. eu chegava assim, "Gente, hoje eu vou ensinar uma música em Alemão pra vocês!” “(canta em Alemão) ... Drácula!” Era uma música do Drácula com os números que a gente aprendeu lá no CEL e eu ensinava. Eles saíam "Mãe, mãe, a gente aprendeu Alemão! ”. A gente ensinava. E Francês também. Trabalhava com saúde, alimentação. Eu sempre fui muito de gostar de todas as matérias. Então, dava aula de Português, Matemática, tudo. Criava probleminhas com eles, criava poesia, cantava "Aquarela" 
(pega o violão e toca as notas inicias de "Aquarela" para exemplificar), uma que das que eu mais gostava de cantar. Quando eu entrei na Prefeitura...

P: Quando você entrou na Prefeitura?

V: Em 2002.

P: Dez anos de Prefeitura.

V: Dez anos! Em 2001 eu passei no concurso, foi no final do ano. E comecei em 2002, aí larguei escola particular. Porque não dava mais, né.

P: Não dava pra conciliar os horários, ou foi uma coisa assim, mais ideológica?

V: Várias coisas. O Estado, eu já tinha parado um pouquinho antes. Porque no Estado quando eu comecei a dar aula pras criancinhas e fazia faculdade e curso de línguas eu parei de dar aula no Estado. Quando eu entrei no curso de Inglês eu já não estava mais dando aula no Estado. Porque eu tinha muitas aulas com a criançadinha em escola particular e no XXXXXXX, que infelizmente fechou. Fazia faculdade à noite, era muita coisa. Tanto que no Estado eu precisava de um período completo pra ser eventual, ou de manhã ou à tarde, eu não tinha. Aí eu falei, "Ah, o dinheirinho da escola particular tá dando". E dava para pagar a faculdade. Eu não entrei na USP porque eu estava dando...

P: Porque ia te impedir de trabalhar...

V: Nossa, ia me impedir de trabalhar, eu precisava do dinheiro, né. Lá em casa, meu pai, depois que ele passou uma época boa, ele passou uma época ruim. E nós éramos em quatro e minha avó estava muito doente. Bom, eu tinha que trabalhar, resumidamente, para comprar minhas coisas. Comecei a namorar, queria passear. Aí eu pense $\mathrm{i}$ "Se eu estudar na USP esse intervalo de tempo que eu vou levar pra ir pra lá eu não vou conseguir trabalhar". E o meu curso eu até optei pelo Francês lá.

P: Ah, é? Eu não tive como optar no vestibular, eu tive que fazer o Ciclo Básico e depois de um ano escolher. Mas antes era assim, né, já no vestibular já podia escolher,

V: Podia. Podia escolher a língua e fazer a prova daquela língua. Eu fiz a prova de Francês. Eu lembro que foi muito engraçado (risos). Falei "Nossa, Francês eu vou manjar! Inglês, se eu pegar Inglês eu não vou saber nada." No fim, a prova de Inglês estava mais fácil, bom, entre aspas, do que a de Francês. A de Francês tinha muita coisa que naquela época eu não sabia. Coisas de gramática...Meu curso era...

P: Focado em fala, né...

V: Básico, né. Focado em fala, focado em comunicação em Francês. O curso do XXX não é tanto gramática. Tem muita gramática, mas não tem tanta assim a ponto de você entender, nem tanto vocabulário a ponto de você entender um texto de uma maneira que hoje em dia a gente tem, que é uma maneira assim mais superficial, uma leitura até do curso que a professora dá, que um curso de... Que não é aquela gramática em si, né... O Inglês instrumental. E eu não manjava de Inglês ou Francês instrumental. Não sabia catar no texto essa informação, scanning, skimming... E aí... eu prestei pra Francês e desisti. Falei “Ai, mãe... Ai, pai... Olha o tempo do percurso..."

P: Mas você chegou a cursar?

V: Não. Não. Nem pensei. Inclusive eu desanimei no meio do caminho, quando eu fui fazer a primeira prova eu comecei a ver o período e o horário... Eu passei na primeira fase, mas quando eu fui fazer a prova de redação eu já não passei. Na verdade, não é que eu não passei, eu nem terminei de passar a limpo a redação.

P: Já desistiu fazendo a prova.

V: É. Eu sei que a minha redação ficou muito boa, mas eu não passei a limpo não. Não deu tempo. Eu quis caprichar e compreender o tema e nem passei. Aí eu falei "Nem vou me preocupar porque nem vai dar para mim, para a minha realidade". Aí fui prestar outras provas, prestei na XXX e passei em terceiro lugar. Prestei também numa outra, não me lembro qual, passei em sexto lugar. Também, as particulares não exigem tanto...

P: Mas mesmo assim, terceiro lugar, sexto lugar...

V: Fui bem. Eu lembro que meu pai ficou orgulhoso porque ele estudou na Universidade XXXXX também.

P: Seu pai fez o quê?

V: Ele estudou Contabilidade. E aí ele ficou todo orgulhoso, "Nossa, a Vívian passou!" . "Olha pai, não passei na segunda fase da USP, mas...". Porque se eu passasse, sabe o que ele ia fazer? Do jeito que meu pai é, ele ia falar, "Vívian, estuda que eu pago para você" e ele ia ter que fazer horas extras. Eu não queria fazer meu pai sofrer. E minha mãe cuidava das minhas irmãs. As minhas irmãs...

P: São mais novas?

V: São todas mais novas que eu. E aí eu pensei "Não vou fazer essa desfeita". Estudei na Universidade XXXXX, foi muito bom o curso. Comecei a trabalhar dando aula, trabalhei seis, sete anos em escolas particulares. Teve escolas muito boas e teve escolas muito ruins. Teve escolas que tinha muito aluno... Parecia escola pública. Você não conseguia dar conta de uma turma de trinta e sete, trinta e oito alunos e não tinha um ensino particular. E eu sentia um desgosto porque nossos alunos pagam tanto para ter o mesmo ensino que os alunos estão tendo em uma escola pública. Eu achava uma injustiça. E eu caí fora nessa época. Tive também dificuldade. Teve uma escola em que eu trabalhei que, vamos dizer assim, foi justamente essa que tinha muito aluno, os pais 
reclamavam porque "A professora não corrige as lições todos os dias." Eu ficava duas aulas por semana com os alunos e eram muitos alunos.

P: Não dava tempo.

V: Nossa! Juro! Não dava tempo! Ou eu ensinava ou eu olhava caderno. E eu levava aquele bolo de caderno de capa dura para casa, tomava ônibus para ir para casa, para corrigir uma vez por semana. $E$ às vezes ficava um caderninho lá sem corrigir. Eu sei que eu não dava conta. Porque eu gostava mais de ensinar e tal do que ficar vendo detalhes. E os pais às vezes "Professora, você não corrigiu que meu filho não fez o til no balão." Sabe umas coisinhas simples assim? Mas lógico, com razão, não vou tirar a razão deles, mas me cansava muito. E eu gostava de dar aula de verdade. Eu não era aquela professora que chegava como a gente tem colegas que pensam, o que o pai valoriza? O que a escola valoriza? Que eu chegue pontualmente e que eu escreva no diário? Vou escrever o mínimo, vou chegar pontualmente. Vou dar minha aula, fingir que ensino e o aluno finge que aprende. Vou pôr lá na lousa uma atividade assim "Pinte a mãozinha do menino. Hand. Pinte a hand". Legal, pintar a hand, acabou a lição, parabéns, congratulations! Acabou a lição do dia. Livrinho, apostila. Bem no meu ano começou a ser apostilado o curso de primeira a quarta série. Não dava mais para fazer o que os professores do ano passado faziam. Dava uma folhinha da sulfite mimeografada, pinte a hand, era a aula do dia e o aluninho saía todo feliz porque ele aprendeu hand. Tinha que ser um monte de coisa no mesmo dia para dividir naquele ano. Os livros eram enormes. Você tinha que dar caderno de atividades, livro paradidático e livro. Era muito conteúdo. Eu juro que não aguentei. Os alunos gostavam da minha aula. Eu trazia musiquinha, coisas que eles iam usar e trabalhava com o livrinho também e trabalhava com oralidade, fazia mesclado. Só que eu percebia que a aula que eles queriam não era mesclada. Eles não queriam que eu trabalhasse com música, não queriam que eu trabalhasse oralidade porque eles queriam a aula apenas de escrita, o aluno na faculdade vai usar apenas a parte escrita. Eu falava "Nossa, não é justo! Criança não vai aprender que bola é ball? Ele vai ficar falando báu o resto da vida?" Eu achava aquilo injusto. Eu pensava "Pra quê tanto conteúdo? Teto e não sei mais o quê?" Aí que eu tive que aprender teto (risos) e coisas assim que eles não usam tanto. Pra quê? Isso daí nem eu sei e já fiz faculdade. Eu achava injusto aquele tipo de conteúdo mas eu nunca falei isso para os alunos nem, lógico, tinha que ter ética profissional, eu dava e no final do ano eu saí fora daquela escola e aí eu comecei a dar aula particular. Muita criança me procurava e prestei no final daquele ano, em 2001, prestei e passei na Prefeitura em curso de Inglês.

P: Não Português, pra Inglês.

V: Nem prestei Português. Falei "Nossa, estou gostando mais de Inglês do que de Português". Português, eu tinha uma turma de Português nessa escola onde eu trabalhei um ano só. Gostava muito de Português, mas eu gostava mais de Inglês primeiro porque eu conseguia conhecer mais crianças e ter mais variedade, aprender mais, com mais variedade de criança, de cultura, eu gostava muito de conhecer gente nova e jeitinhos novos. $\mathrm{E}$ gostava também de ensinar Inglês porque Inglês você tinha mais tempo de trabalhar com música e variedade. O Português era tanta parte gramatical que os cursos de escola particular exigiam que eu achava que na escola da Prefeitura, a gente tinha aquele olhar de que a Prefeitura é super exigente e seria igual escola particular. No fim é médio, é entre o Estado e a particular, na minha visão, né. E aí eu comecei a fazer o quê, prestei pro Inglês, passei e aí comecei a ver a realidade da língua, eu não tinha livro, não tinha nada. Você podia trabalhar com o que você achasse importante.

P: Uma autonomia maior, né.

V: Uma autonomia maior. Eu e os professores fazíamos os planejamentos anuais, víamos um planejamento de currículo municipal e estadual. Então a gente trabalhava em cima de certos planejamentos que existiam por aí. Não existiam esses currículos que hoje têm no Estado e na Prefeitura. Mas a gente via o que mais ou menos as outras escolas particulares trabalhavam e fazíamos os currículos. Comecei a pegar EJA.

P: Já em 2002?

V: Já em 2002. A primeira turminha que eu peguei já foi de EJA. Eu trabalhava para lá do bairro XXXX com EJA à noite, só que meu horário era todo picado. Eu tinha três escolas diferentes. Aí eu não conseguia mais conciliar com tantas escolas particulares, eu fiquei só com duas, só com criançadinha para poder ter essa variedade.

P: Então eram cinco escolas diferentes.

V: Cinco escolas. Era incrível. Saía do bairro XXXXX às $17 \mathrm{~h}$ e tinha que estar às $19 \mathrm{~h}$ lá em Costa Norte, tinha que pegar ônibus lotado... Bom, sofrimentos à parte, eu comecei a trabalhar com a música, a levar o violão para a escola. E a EJA era à noite e eu já tinha experiência de trabalhar com adultos por causa do coral da minha igreja. Pensei que seria igual ensinar música para adulto. Comecei a ensinar Inglês para adulto. Lógico, no começo era bem infantilizado, depois eu fui começando a perceber que dava para fazer coisas diferentes, mas que eles gostavam também dessa coisa carinhosa de você chegar, por exemplo, e dar uma nota no caderno. Eu nunca achei que eles gostassem, imagina que eu olhava o caderno no começo do EJA? Não olhava, ah, tudo adulto.

P: Tudo adulto, eles se viram, né.

V: Eles se viram. Aí eu comecei a ver que eu passava pelos lugares e eles não estavam copiando da lousa direitinho. (56:25) Era de quinta a oitava, mas tinha muitos que não sabiam escrever direito Português. Aí que eu 
comecei a perceber que de certa forma é necessário você também dar aula de Inglês associada ao Português. Então eu comecei a trabalhar também o Português. Igual criançada.

P: Ajudando eles a estabelecer relações, né.

V: Exatamente. “Apple, pessoal, é maçã.Vamos escrever?”. Na verdade, então, eu estava cobrando o Português. Não podia cobrar o Ingles porque eles estavam aprendendo agora. Na prova eu cobrava Inglês. E dava provinhas. Tinha professor que não dava, mas eu dava.

P: Você está no Centro Educacional Trandisciplinar há quanto tempo, Vívian?

V: Desde 2009.

P: E por que você escolheu o Centro Educacional Trandisciplinar? É uma escola que inclusive tem uma seleção...

V: Difícil...

P: Difícil para entrar, né. Então, você pode me contar como foi?

V: Essa prova de redação, assim, nível USP, Fuvest, realmente é uma prova de concurso público. Na prova do concurso público, eu acho que eu fui melhor na redação de lá do que na do Centro Educacional Trandisciplinar, mas a minha redação passou em segundo lugar. Foi mais ou menos continua. Eu trabalhava no XXX. Eu tinha passado no concurso da prefeitura para professor adjunto.

P: Mas aí o concurso é diferente?

V: Não. Era a mesma prova de concurso, mas tinha essa diferença porque o professor titular tinha uma escola só, fixa, e o professor adjunto era mais fácil passar. Hoje em dia não existe mais professor nem prova de adjunto, só titular. Em 2009 todos os professores adjuntos passaram a ser titular, mas o governo criou o cargo chamado de módulo, que é o professor concursado que pega vaga que sobrou na escola. Então quem tem menos pontuação, por uma série de critérios, como tempo de carreira, acaba não tendo prioridade na escolha das vagas. O professor fica em módulo quando ele sobra na escola. O que é o módulo, você dá as aulas quando os professores faltam. Tem que cumprir as horas da semana, às vezes em sala com o aluno, às vezes preparando atividade, outras coisas como mural, outras coisas. Eu nunca precisei trabalhar como módulo. No ano em que eu fui passada como titular, em 2009 (quando esse cargo de professor adjunto foi extinto e consequentemente todos os professores passaram a ser titulares) eu já estava aqui. Como eu vim pra cá, eu fiquei sabendo do concurso e decidi prestar. Foi um amigo que falou. "Mas é legal?" "É sim, é EJA, igual aqui. Só que é Centro Educacional Trandisciplinar, um pouquinho diferente, você vai gostar. Você é dinâmica, traz violão pra escola, faz isso, faz aquilo com os alunos, lá você tem que dar aula de Português, Inglês, Arte e Educação Física". Eu falei "Nossa! Que dez! Vou me realizar! Será que eu vou passar?” Porque eu amo tudo isso, né! Falei até para o meu namorado na época prestar, ele nem acreditava, quem fez a inscrição dele fui eu. No fim, ele passou antes de mim. Em 2008, um ano antes, a gente prestou essa prova em 2008, é verdade, a gente passou, mas não me chamaram porque não estavam precisando do meu cargo; estavam precisando do cargo dele, que é Ciências Humanas. Aí, ele passou e começou a trabalhar aqui um ano antes. No ano seguinte, prestei de novo, a gente tem que prestar a cada ano que tem, prestei de novo e aí estavam precisando do meu cargo, passei. Aí nos dois trabalhamos juntos até hoje aqui. E amei, amei. Aí de 2002 eu estou na Prefeitura e de 2005 eu estou no Estado. E quando eu entrei aqui, lógico, eu larguei as particulares, as dos pequenininhos. Nossa, não dava; quarenta horas semanais da Prefeitura com mais vinte horas do Estado são sessenta horas semanais mais a igreja e as aulas particulares de música que eu dou... Então é muita coisa.

P: Sobre o ensino de Inglês e de tecnologias digitais, eu já fiquei sabendo que você já esteve aqui na informática bastante, né, com mais aulas, inclusive. Como você vê isso no mundo de hoje? Não aqui na escola, mas no mundo.

V: Você fala do uso da tecnologia pelo ser humano, algo bem filosófico?

P: Não tão geral assim, se você pensar, o uso de uma faca é uma tecnologia também. Eu digo o uso de novas tecnologias, como o computador e a internet. Embora pareça haver um duplo foco, eu vejo muita relação entre o Inglês e as novas tecnologias.

V: Nossa, dá para falar muito sobre isso. Muito, muito, muito.

P: Então, assim, como você vê o uso das tecnologias digitais na sociedade e depois de uma perspectiva escolar, da sua realidade, com seus alunos.

V: Quando a gente pensa em tecnologias digitais associado a Inglês a gente já pensa nas palavrinhas básicas, né, mouse, $C P U$, etc...

P: Exato...

V: Os próprios CDs, né, DVDs e muitas vezes as pessoas não sabem que é palavra em Inglês. Então, começando daí a nossa reflexão, eu acho que uma coisa interessante de a gente abordar é isso. Quando eu comecei a dar aula de informática, inclusive, eu usava muito o Inglês, ensinava muito Inglês. Eu falava, "Vocês sabiam que mouse é uma palavra em Inglês?” “Ah, é?”. Juro, eles não sabiam.

P: Um abrir de olhos, né.

V: Tranquilo. E escreviam mause com "a" e nunca tinham percebido que se escreve com "o" mas porque não vê a palavra escrita. Eu vejo assim, o povo, a sociedade nossa, ela ainda não usa o Inglês o suficiente. 
P: Então, será que é isso mesmo? Eu tenho notado isso na fala de alguns alunos. Não sei nem se eu deveria estar falando isso, para não influenciar.

V: Não, não. Mas é exatamente isso. É pena que você não pegou o começo do ano. E pena que muito aluno não pegou. Só que eu já estou falando da particularidade, né.

P: Não, podemos falar primeiro do geral só para organizar, mas se você quiser pode falar por aí também, não tem problema.

V: Então, vou voltar ao foco, depois vou ter que voltar a isso para manter a reflexão. Quando a gente pensa em sociedade, a primeira coisa, eu já entrevistei muita gente, o que que o povo vê do Inglês... "Ah, língua de Norte Americano e estrangeiro, de gringo! Você acha que eu vou querer aprender língua de gringo? A gente não usa, não fala nada do Inglês, não tem nada aqui de Inglês". As primeiras coisas, né, a gente percebe um afastamento. Um afastamento por não saber e por não perceber que ela está incorporada como outras línguas. O Francês, quantas palavras você não tem, como sutiã, vem do Francês, joalheria vem do joalerix. A gente vê que muitas vezes a pessoa não abre o olhar mesmo. Então, muitas pessoas nem entendem como no dia a dia aprendem o Português, acham que Português, História e Geografia é língua da escola, então, na prática ele não está achando que está aprendendo nada. Assim, estou falando a nível de Brasil que é o que eu conheço, tá. Então assim, no Brasil eu vejo que a gente não tem uma cultura de perceber o quanto a gente aprende na vida, no dia a dia, nas placas, ou numa conversa, numa leitura de jornal. Tanto que a escola não é valorizada.

P: Pergunto uma coisa. A escola tem aberto mais o olhar, tem tentado estabelecer uma ponte com as coisas da vida? O que que tem acontecido, para você que está de dentro? Eu tenho visto isso de fora.

V: Essa história vem de longe. Você sabe que a história da escolarização começa com dominação. Se a gente estudar história da educação a gente começa a perceber por que começou-se a criar escolas? Antes, os governadores, os dominadores, punham os filhos para estudar com tutores. Isso na Grécia também, eram tutores, punham dois, três lá.

P: Não havia escolas, né.

V: Não tinha parede, não tinha isso (apontando para a parede). Então nesse momento, a escola começou a virar uma instituição. Daí, de uma instituição para ser dominada pelo governo... Hoje em dia podemos falar, não temos mais ditadura. Então você vê que pra passar de uma fase de dominação, fácil. Por isso que se criou esse tipo de instituição, a escola pública. Existem milhares de fatores contra a abertura do olhar, contra a visão do outro, do diferente, das culturas diferentes, porque se quer focar na nação. O povo ainda é muito nação, ele não entende que o que ele faz aqui, na nação dele, reflete no mundo todo. Se ele não cuidar da árvore que está aqui na Amazônia, o mundo todo vai sofrer. Se ele gastar papel lá na China, gastar papel demais e não reciclar, e aí vai... Acho que no dia em que o povo começar a perceber que tudo é tão associado, ele vai viver melhor, ter mais qualidade e vai também explorar melhor na educação o que se aprende, o que se pode aprender o que se usa na vida. Nós somos filhos dessa história. Nós temos reflexos do que os nossos professores ensinaram para nós. Tanto que a minha prática com certeza tem oitenta se não noventa por cento que meus professores também eram e são hoje em dia ou alguns já foram. Então quando você fala de, como fazer esse gancho da realidade para a escola que eu até citei, né, usa-se muito... Ah, não, se o Português que é uma língua não está na vida deles, como o Inglês vai estar. Se nem a História que está no dia a dia ...

P: Se abrir o jornal, você vê a História ali.

V: O cara sabe que chama Primeiro de Maio a pracinha, mas não sabe por quê. Aí, no Primeiro de Maio, lota de gente, nossa, está tendo festa! Então esse gancho, você perguntou sobre as tecnologias hoje e o uso de Inglês. Porque normalmente a gente percebe que o pessoal está mais se aproximando da tecnologia e do Inglês, não. Eu acho primeiro que é cultural. Tem essa questão cultural, tem essa questão histórica muito forte. A questão de ter preconceito. Há muito preconceito. Incrível, né. Mas ainda há preconceito. Há também dificuldade porque é outro trabalho bucal e labial e a língua e tudo, é diferente a pronúncia. Nós, na sociedade temos o Inglês, por exemplo, nos filmes, nas músicas, em quase tudo. A dominação do Inglês, ela é muito forte, né. E é uma língua fácil, entre aspas, se comparar com outras, né, Japonês, né, que é bem mais distante da nossa língua. Mas mesmo assim, o pessoal não percebe o quanto consegue aprender. O jovem hoje em dia, não só hoje em dia porque na época da minha mãe também, tem muitos jovens que começam a gostar de uma banda Inglesa ou de um grupo ou de um cantor Inglês, eles começam a aproximar mais de Inglês.

P: Comigo foi assim (risos).

V: Minha mãe também. Ela começou a gostar de Beatles, ela traduzia todas as músicas dos Beatles, ela traduzia sozinha. Ia traduzindo mais ou menos assim, né, não tinha Internet. Hoje em dia a gente, com a rapidez que a Internet está, você pega a tradução na hora. Você não tem mais nem tanto trabalho. Talvez a gente possa até refletir sobre isso. Não tem mais tanto trabalho para ir atrás.

P: É, só de bater o olho, você não faz nada com aquilo. Não se envolve tanto.

V: Pra quê? Não vou usar, ué! A tradução está pronta na Internet... Só que eles cantam, eles cantam em Inglês. Os que gostam de música e têm contato. Porque tem gente que não têm contato nenhum, vai gostar como? Então, tem muita criança e muito jovem que aprende Inglês dessa forma e começa a perceber, começa a abrir um pouquinho mais o olhar. Agora poucos aprendem, percebem... 
P: De outras formas?

$\mathrm{V}$ : De outras formas.

P: Pelo jeito como a escola...

V: Exato! Eu dei um ditado. Eu falei hot dog no ditado... "Professora, hot dog não é Inglês!"

P: (risos)

V: Juro! Oitava série no Estado. Outros, até não quiseram falar, né, são menos bocudinhos, fizeram assim (expressão de dúvida) e não sabiam escrever hot dog. Eu dei ditado, fiz uma lista de todas as palavrinhas usadas no Brasil, sabe, e a gente trabalhou bastante esse ano na oitava série, porque é uma oitava série bem fraquinha... E o pior é que eu falei, isso daí a gente nunca trabalha na escola, mas tem que trabalhar sempre. Começar do que a gente usa, porque aí vai fazer um gancho maior, né. Dar texto, ué, como é que a gente consegue entender um texto que a gente nunca viu lá milhares de palavras? Através dos cognatos e através dessas palavrinhas conhecidas nossas. Não é assim? Você vê palavrinhas usadas no Brasil, você vai fazendo ganchos e às vezes você descobre outras, né, que a gente não sabe... E aí a criançada começou a perceber, falar "Nossa, professora, é mesmo, né. Quando eu escrevo, vai, 'Eu comi um hot dog no shopping e comprei um - sei lá, uma lingerie - ah, lingerie é do Francês - uma top, uma baby look, um short, uma jeans, pronto. Você está falando e escrevendo Inglês e nem sabe.

P: Tem uma reflexão, que estou lembrando agora. Eu estudei Tupi na faculdade.

$\mathrm{V}$ : Legal!

P: Foi um semestre só, foi mais para tentar me colocar na posição do outro. Olha, como sou professora de Inglês e às vezes eu não entendo a dificuldade dos meus alunos, então, vou me colocar em contato com uma língua pela primeira vez, tal. E aí o professor fez essa sensibilização do tanto de palavras Tupi que existem no Português, né. E aí ele estava contando uma história de alguém que perguntou pra ele como que se diz shopping em Tupi. E eu pensei, como isso tem a ver com o contexto. Não existe shopping em Tupi. Tem coisas que não estão na realidade dessa língua. Então, trazendo essa carga cultural, mesmo.

V: E hoje em dia. Por exemplo, hoje em dia tem gente que ainda fala Tupi, não tem?

P: Na verdade, o Tupi é como se fosse o Latim. É uma língua que deu base pra muitas outras línguas indígenas que são faladas hoje, mas ela não é mais falada.

V: Nossa, que curiosidade que me deu. Os índios na Amazônia, alguns em Parintins, locais que ainda tem índios, assim, que falam... muitos índios falam Português e a língua mãe deles.

P: Sim.

V: Então eles têm o professor da língua mãe deles e a criançadinha também e eles vão estudando as duas [línguas]. E aí, para aprender esses termos da atualidade, será que eles traduzem, será que eles já fazem uma ponte ou eles aprendem como se fosse Português já, né? Já como estrangeirismo? Pode ser...

P: O próprio Português é uma língua, talvez não língua estrangeira, mas segunda língua, né, se eles tiverem bastante contato com brancos... Então é segunda língua, não é língua estrangeira. Mas dependendo do caso é língua estrangeira até, de repente ele só vê na TV. Interessante, né.

V: Pode ser que eles achem que shopping é Português porque está tão incorporado. Até os nossos alunos acham. Até nós que falamos Português todo dia. Interessante, muito bom. E aí a gente aprende, né. Olha como eu aprendi aqui com você. E aí, será que eu já respondi a sua pergunta?

P: Já.

V: E na escola é a mesma coisa, né. A gente começa a perceber a criançadinha dessa forma. Eles fazem poucos links. Eles também falam que não gostam de Inglês.

P: Por quê?

V: A maioria fala que não gosta. Os mais velhos da oitava série, que já tiveram Inglês, sexta, sétima, oitava, falavam assim, "Professora, não gosto porque não sei". Os que são mais honestos falam assim.

P: No fundo, é isso o que eu vejo também.

$\mathrm{V}$ : É porque não sabem.

P: Essa resistência na verdade é pela dificuldade mesmo.

V: Porque ele acha, sabe aquele perfeccionismo? Tanto do aluno quanto do jovem? Se você não souber... O que que é saber para eles? A ideia de saber ainda está imatura na nossa sociedade. Nossa, a ideia de ter raiva é tão imatura na nossa sociedade, né? Pensa, eu estava pensando nisso ontem, antes de ontem... A ideia de ter raiva, a nossa sociedade não aceita quem tem raiva, quem tem medo...

Denise

P: Quem tem medo principalmente...

V: Nossa, isso é super natural e é necessário o medo para a sobrevivência. E a raiva também. É um sentimento que não pode virar... uma raiva violenta, aquela raiva que vira ódio, aí doentio, mas é necessária a raiva, ué, a gente não sente? A gente tem que saber trabalhar com essa raiva. Aí a área de psicologia, é que eu assisti uma palestra de uma psicóloga explicando sobre a raiva no CNU, naquele Canal Universitário...

P: Interessante. 
V: Nossa, muito bom. Sobre a raiva, por causa das novelas. Não tem essas novelas que estavam tendo uma brigando com a outra? Não lembro o nome agora...

P: A Avenida Brasil...

V: Nina e Carminha.

P: Nina e Carminha. Sempre que aparecem essas personagens que brigam, que chutam, que batem, que enterram o outro vivo...

$\mathrm{V}$ : (risos)

P: As pessoas adoram, né, porque elas não se permitem sentir aquilo.

V: Olha...

P: Então ver o outro...

$\mathrm{V}$ : É mesmo, né... Não... mas

P: Mas veem mesmo assim, porque "Eu sou superior, essa pessoa horrorosa agindo dessa forma não sou eu" (risos)

V: Ou então, né “Ai, essa novela, pelo amor de Deus, nossa muito...". Tudo bem que muitos não assistem por opção porque não gostam mesmo de ver cenas de violência ou cenas assim de tanta maldade, é maquiavélico, né... aquilo planejado, tal e depois pra gente mesmo aquilo ser novo. Assim, muitos alunos adultos, a maioria assiste, mas tem os evangélicos, por exemplo, que não assistem novela, nem televisão. Então você fala, às vezes quer fazer um link da realidade, é complicado também. Tem muitos que não vão a shoppings, compram as coisas em lojinhas pequenas perto do local onde eles moram. Tanto, aqui tem shopping em XXXX? Não tem... Tem gente que não vai para a XXXX, para o shopping. Então não sabe o que é um shopping, não sabe o que são certos termos, não tem celular, incrível hoje em dia... Tem muita gente que não tem celular. Eu mesma tenho celular há um ano. Juro! Fiquei sem celular um tempão. Então aí, P, você vê que pelo que a gente percebe, o Inglês está distante por muitas razões, muitas e tem muito chão pela frente. Eu acho que primeiro a gente precisa conquistar a língua em si e o estudo, o valor do estudo.

P: De você, uma pessoa que estudou tanto língua, né, quando adolescente ainda, foi atrás. Não foi imposição?

V: Foi interesse. Só a música que meu pai deu uma forçadinha...

P: Mas você gostou, né... Então, você valoriza o estudo, né. A primeira coisa que eu falaria sobre você... estudiosa... curiosa.

V: Pelo menos buscar, né, a gente gosta muito. E isso daí é por causa do meu pai e da minha mãe. Essa curiosidade, ela... lógico, se eu for pensar, minhas irmãs, elas são curiosas mas elas não buscam. Faltou isso um pouquinho nelas, tanto que todas largaram os estudos e da mesma família todo mundo.

P: Não é tão determinante assim, tem muita coisa...

$\mathrm{V}$ : Da gente e também coisas do convívio. Eu tive amigas muito estudiosas. Os camaradas, digamos, das minhas irmãs, não teve tanto isso, eram mais aqueles de cabular aula. Minhas duas irmãs do meio pararam de estudar no colegial e agora elas terminaram e fizeram à distância, fizeram EJA também. E fizeram faculdade, terminaram agora, as duas do meio, né, e a mais nova terminou antes delas. A mais nova, chama T. P.

P: Olha só, que nome bonito!

V: E no fim, minha mãe nem sabia que a mais nova ia nascer de cabelinho preto igual eu. Minhas duas do meio são loirinhas.

P: Que coincidência, né.

V: E ela fez Letras também.

P: Que legal. Bom, Vívian, eu ficaria, mas eu estou vendo que estou abusando. Já são quase duas horas de entrevista já.

$\mathrm{V}$ : Imagina...

P: Eu ainda tenho algumas coisas mais específicas, e eu acho que você vai falar bastante para responder e não quero te cortar ou ir embora no meio da sua fala. Acho que vou te mandar as perguntas para você responder por escrito ou marcar outra entrevista.

V: Pode mandar e pode marcar outra entrevista.

P: Posso? Nossa, que bom, vou ter muitos dados a partir disso, então (risos)

$\mathrm{V}$ : Você que sabe. Eu não tenho muita coisa para enriquecer, talvez.

P: Imagina, isso tudo que você está falando está iluminando muitas coisas, de uma pessoa que está trabalhando há bastante tempo com esses alunos. Do tipo, por quê esses alunos conseguem falar tão bem sobre a informática e não conseguem falar do Inglês ainda tão bem?

V: A informática está em tudo, olha, o celular...

P: Ao mesmo tempo em que os alunos, o celular acho que nem tanto...

V: Mas sabe que isso aqui (apontando para o teclado do celular) é digitação.

P: O celular é mais predominante. É muito difícil ver alguém que não tem celular. Você vê mendigo usando celular. Numa discussão que eu vi lá na universidade, tiraram uma foto de um carroceiro usando um celular, isso gerou uma super discussão. 
V: É igual na África, né. Não dizem que eles tomam Coca Cola, não ficam sem Coca Cola, mas eles não têm às vezes o que comer.

P: Então, são coisas que dão um nó no pensamento.

V: No Carnaval também há um exemplo. Quantos pobres usam aquelas roupas...

P: Maravilhosas...

V: Trezentos, quatrocentos reais...

P: Mas...

V: Não compram a roupa do corpo. Mas pagam todas as mensalidades da roupa durante o ano todo anterior para dançar no próximo Carnaval.

P: São coisas que a gente fica um pouco chocado pelo contraste, mas que vão além do que a gente pode entender só de primeira coisa que a gente pensa, né. E... muitos alunos às vezes não têm computador ou só tem acesso mesmo por causa da escola e mesmo com certa dificuldade para usar o computador na escola, sabe falar muito bem sobre o computador.

V: Todas as utilidades, né... Porque tem muita utilidade, né, o computador.

P: Claro, mas também o Inglês, não.

V: O Inglês também. Só que a gente ainda tem que descobrir muita coisa do Inglês. Há muita coisa, não só do Inglês, sabe de todas as línguas? Desde a língua Portuguesa. A informática, por exemplo, tem alunos nossos, eu dei aula de informática no ano passado. No ano passado eu só tinha informática. Meu Deus! Eu lembro que eu sofri muito no começo porque eu achava que todo mundo sabia tudo! Porque eu falava, quem é que não tem um computador hoje em dia? Nossa, vou chegar lá, que que eu vou ter que ensinar? Nada, quase!

P: Você achou que ia ser fácil?

V: Achei! Nossa! Achei que fosse super fácil. No fim, eu tive que dar aula de Português, de História... qualquer assunto que eu abordasse, eu tinha que trabalhar aquele assunto mais a tecnologia. Entrar na Internet, um, dois por sala sabiam entrar na Internet. Os mais jovens, mesmo alguns jovens não sabiam. Em EJA, a maioria é adulto, mas tem muito jovem.

P: Mesmo os jovens que a gente acha que é mais interessado nisso, né.

V: Teve jovens que não sabiam pesquisar um assunto na Internet. Eles sabiam entrar no Facebook, mas não sabiam pesquisar um assunto na Internet.

P: Por que você acha que é isso, Vívian?

$\mathrm{V}$ : Interesses e foco.

P: Mas por que o foco no Facebook? Eu tenho algumas hipóteses, escutando outros professores de informática que falam a mesma coisa. Sabem entrar no Facebook, só querem entrar no Facebook.

V: São redes sociais. Porque se sente bem, porque gosta, porque é fácil para ele, porque ele já treinou aquilo. Facebook, um amigo te ensina a entrar. Oh, como é que é, que legal, é assim. Rapidinho aprende. Eles sabem coisas que eu não sabia. Postar foto, postar não sei o quê. Eu aprendi muito com os meus alunos também (risos). E aí você... tem redes que existem outras redes sociais. Através da rede social ele está falando com o amigo, com a amiga, pondo as coisas dele. É um diário. Ele está falando aquilo dele, ele acha que ninguém está vendo, né. Ele acha (risos). Aí tem toda essa parte, né, do que que ele vai pôr lá, ele não tem noção também do que ele está pondo... Põe coisa que não era para pôr, vai, ou que ele não está nem sabendo o quanto ele está se comprometendo. Além disso, ele sabe o básico, ele sabe assim, fuçar, mas ele não faz a análise do que ele está aprendendo com aquilo também. Ele está só querendo ser a gracinha, então, por exemplo, o carinha fala, eu mandei uma assim, né, "Olha como a Coca Cola faz mal à saúde". Aí coloquei lá, tinha na Internet umas fotos das pedras que fazem no estômago da gente e tinha até um cara com a mãozinha na barriga e tal. Aí, um amigo meu, "é por isso que eu tomo cerveja..."

P: (risos)

V: Quer dizer, eles querem ser o quê? Palhaços, brincar. Só que eu não, não quero ser palhaça. Eu me pergunto toda hora.

P: Por que você não entra na brincadeira também, né?

V: Eu brinco também, mas eu brinco assim. "Aeee, hahaha, kkkk" mas, não achei graça nenhuma, né. Eu ponho lá kkk, tipo dando uma risadinha. E assim, eu não vejo graça porque eu acho que ali não é real, eu vejo muita fantasia ali, né. Eu gosto, é viciante, não é, P, você tem também Facebook?

P: Tenho.

V: É viciante. Você começa a entrar e você fala, "Meu Deus, eu não dei parabéns para as amigas que fazem aniversário". Só que as amigas, eu tenho mais de duzentas amigas. "Nossa, quantas estão fazendo aniversário hoje? Três. E amanhã, tem mais duas. Amanhã não vai dar tempo de entrar, meu Deus". Fica assim, nervosa porque não pode, aquele perfeccionismo que a gente tem um pouco sempre. Não pode, não dá, não vai dar tempo de eu mandar um parabéns, eu quero mandar, é respeito. Você começa a se cobrar mais ainda e gastar mais tempo com coisas, vamos dizer, fúteis. Às vezes um amigo que nem te deu parabéns ou que nem fala com você, só porque ele é seu amigo na internet, você se sente na responsabilidade de dar parabéns para ele. Às vezes o cara está lá só de passagem, está perdendo um tempinho a mais lá e a gente, não, a gente tem tanta coisa para 
fazer, que acha mais útil. Por que não dar valor àquilo que você acha útil? Eu gosto de ler, vou ler um livro... Não vou ficar brincando na Internet.

P: Pra poder socializar, será, porque está todo mundo... É como a novela, está todo mundo assistindo, então...

V: Eu tenho que assistir, né... Que nem, eu não tenho tempo de assistir novela, o que que eu faço, eu dou uma fuçada na Internet e vejo que está acontecendo para poder também falar com os alunos.

P: É isso o que eu ia falar, para ter assunto (risos)

V: Para ter um pouco de assunto e puxar daí. Igual música, eu não gosto dessas músicas que eles gostam, mas eu faço o quê... "All the single ladies, all the single ladies" (cantando)... Essas músicas, né. Você pega e aprende um pouquinho, né. Ah...Single ladies, all the single ladies... (cantando) Aí falei, "O que ela está falando?". "All single ladies". E meus alunos, "Professora, o que é singoledo? Singoledi?"... Sei lá como eles falavam. All the single ladies (cantando)... Aí falei, "Gente, acho que não é isso...Será que é isso o que ela está falando?". Aí fui lá no Youtube e descobri (risos). E eles perguntam toda hora, "Professora, o que é blablabla?", não sabem a pronúncia direito, então eu pedia "Escreve aqui para a professora que eu tento traduzir". Muito engraçado mas é muito bonitinho, porque eles estão tentando. Eu falo "Aê, parabéns, congratulations!" Mas sabe o que eu não vejo ainda, P, uma utilidade real do Inglês, na vida assim, de maneira que eu possa falar "A gente está aprendendo para isso". Eu não vejo ainda isso, eu mesma não vejo. Então, assim, da tecnologia, sim, eu vejo mais da tecnologia do que do Inglês. A tecnologia, ela tem toda uma utilidade que está sendo cobrada de tal forma socialmente que é muito forte. Não é só o mercado, uma empresa de cartão, ou o computador do banco, não, não é só. É uma cobrança social e o social influencia muito na gente, nós somos sociais. Agora, Inglês, tem uma cobrança social? Tem um teatro, uma peça em Inglês que está passando aqui que a gente quer assistir e só tenha em Inglês? Não. Fazem versões das peças, tudo tem versão. Então o cara faz a versão, graças a Deus nós temos artistas inteligentes, diretores e tradutores, traduzem e pronto, a se familiariza e acaba fazendo esse encontro com a outra cultura através... nossa, interessante, né... através da tradução. Agora, você vai ver, como vai ter um monte de gente querendo estudar Inglês se também não for ao contrário, porque eles lá aprendem Inglês, se eles não chegarem falando em Português aqui porque eles já estão estudando Português.

P: Já estão estudando Português. Interessante, não sei, tenho amigos que até já estão...

V: Se bobear eles estão falando, "Ah, aquele povo do Brasil..." muitos de lá de fora têm essa visão, "Aquele povo do Brasil só quer saber de samba e pagode e sei lá mais o quê... não vai querer ficar estudando a nossa língua, a gente vai ter que chegar lá e chegar com uma bagagem". E aí, de novo a gente não aprende o Inglês... P: Então...

V: Talvez.

P: É, espero, honestamente, que isso mude. Mas acho que pelo gosto mesmo, não pensando simplesmente em ser um recepcionista dos gringos. É uma coisa que sempre me incomodou também de ouvir os alunos e outras pessoas falarem... De ser recepcionista do gringo...

V: De usar no trabalho.

P: De usar no trabalho, mas acho que mesmo pela questão cultural de ampliar seu olhar, né. Ter acesso a outros bens culturais.

V: Uma coisa interessante que nós acabamos de conversar. Eles não sabem muitas vezes a importância, vou até anotar isso aí, é um tópico importante, o quanto essa cultura, não só pelo trabalho... Eles falam bem assim, "Professora, no meu trabalho eu não uso o Inglês"... Falei "Então você pode buscar, você por exemplo viajar para fora"... "Ah, professora..."

P: "Eu não vou viajar".

V: "Eu não vou viajar, eu não tenho dinheiro". A gente faz aquela pergunta, né, "Por que Inglês?" logo no começo do ano. A gente fala muito disso, a gente frisa essa questão. Muitos alunos já saíram da escola, os que participaram dessas conversas, né, mas eu percebo o quanto que eles abriram o olhar. Por que Inglês? Por que estudar Inglês? E não outra língua? Aí muitos falam, "Ah, professora, porque o Inglês está na computação". É uma das primeiras coisas. "Está no computador, está nas músicas, né, a gente tem contato com música, está nos filmes". Então eles vão falando todas essas coisas para mim.

P: Se você pensar em música e filme, a produção e a distribuição também estão relacionadas com tecnologia. Não digitais...

V: Mas tecnologias. Tudo tem a ver com tecnologia.

P: Comunicação e tecnologia.

V: Comunicação é social, totalmente social.

P: É preciso estar frente a frente. Mas por causa da tecnologia você consegue difundir para lugares mais distantes e aí amplia também, a tecnologia possibilita ampliação.

V: Agora, se a gente quer ampliação... É antagônico isso, ó... Se a gente quer ampliação cultural porque isso daqui é tecnologia (mostrando o celular), a tecnologia vai privar isso, com certeza, vai querer que você, quer dizer, vai possibilitar a sua visão mundial. É, não só do seu país, mas do mundo. Se a tecnologia amplia o nosso olhar, ou deveria ampliar, por que (rindo) a gente não percebe isso e não percebe que isso também está em aprender a língua dos outros? Né? Porque através de aprender a língua dos outros, você aprende muito mais da 
cultura do outro.... E não se entende isso. Por exemplo, na escola a gente ensina a falar Inglês (fazendo anotações sobre cada tópico), a escrever Inglês, a ler, a escutar Inglês, né. Aí você ensina o quê? A cultura, você trabalha com a cultura. Aí você aproveita, eu pelo menos faço o link com todas as outras culturas...Eu vou falando o que eu sei, vou trocando ideias... Uma aluna trabalhou com uma família Árabe, falou também coisas da família Árabe, ah, porque eles comem carne assim, assado, fazendo não sei o quê. O outro trabalha com Chinês, ah não, na China eles comem rato, comem gato, comem até feto de gente, e é muito caro. E vamos trabalhar com essas coisas todas até para assustar e se assustar é conhecer o outro. Trabalhar com cultura tem tudo a ver com o outro, é trabalhar com o outro, o diferente de você. E hoje em a intolerância e a violência vêm também muito disso, de você não perceber que o outro não pensa como você.

P: A gente tem uma falsa ideia de que todo mundo é igual ou que todo mundo têm direitos iguais...

V: Direito de ser bonzinho, todo mundo tem que ser bonzinho. Eu sou boazinha e todo mundo tem que ser bonzinho comigo também. Se eu falo oi, o cara tem que falar oi. Nossa, professora, meus alunos, teve briga no $3^{\circ}$ A... Não sei por que o $3^{\circ} \mathrm{A}$ às vezes causa umas confusõeszinhas...

P: Com aquela aluna que falta bastante...

$\mathrm{V}: \mathrm{G}$.

P: Eu não entendi direito o que foi que aconteceu, mas alguém falou, “Ah, porque ela é da pá virada, ela é da pá virada...". Mas eu não vi nada acontecendo...

V: Sempre que ela chega, a gente tenta, eu tento sempre perceber como ela está porque ela enxerga coisas, eu não sei se ela tem uma autoestima meio baixa, mas ela enxerga coisas, assim, não sei se ela cria ou enxerga coisas que a gente não está vendo. Por exemplo, outro dia ela chegou assim e falou assim, ela sempre vem com alguma coisa, "É, professora, tem gente na sala...". Ela usa a hora do debate para jogar contra outros... "Tem gente na sala que a gente cumprimenta, a mulher nem cumprimenta a gente".

P: Aí, já semeando a discórdia.

V: E o povo da sala é pacífico, assim, tem um jeitinho diferente do dela. Meio pacífico assim... a gente vê deles, né, não quer na hora do problema, mas tem muitas ali de sangue quente também.

P: A gente vê que elas estão mesmo, numa política da boa vizinhança.

V: Boa vizinhança... Aí uma vez deu briga com a A. uma de cabelinho vermelho, uma senhora alta, de óculos.

P: Sim, eu acho que é a mais calma de todas, né... Zen.

$\mathrm{V}$ : Justamente, de quem ela estava falando?

P: Da A..

V: "É, porque a gente cumprimenta e a pessoa não fala oi”. Eu falei, “Ah, às vezes a pessoa não viu". Quantas vezes eu não vi meus alunos na rua? "É, professora, te vi na rua com seu namorado e você nem me falou oi". Mas gente, às vezes eu não vejo mesmo. Às vezes você está conversando com alguém, está pensando em outra coisa... Nossa, minha cabeça é maluquinha. Às vezes eu estou com a ideia lá no cafundó do Judas. E eu não vejo mesmo... Coisas do dia dia... E ela não entende, ela quer que todo mundo seja igual a ela. Aí, foi engraçado a A. "Nossa, é só falar de novo! Eu falaria oi para você”. Então, tenta a próxima vez, tenta olhar, 'Oi, fulano!'.

P: É, falar de um jeito diferente.

V: Usa sua criatividade. E ela é esperta, ela é criativa, sabe...

P: Vívian, obrigada. 


\section{Apêndice 11: Entrevista com aluno J. (Centro Educacional Trandisciplinar) em 13 de novembro de 2012}

P: ... porque você gosta de música da Alfa FM, por exemplo, que é uma vivência que ninguém percebe que já é um jeito de aprender inglês ou talvez ninguém valorize, acham que não é aprendizagem, acham que é um entretenimento só, né?

$\mathrm{J}$ : Com certeza.

P: Bom, J., tem algumas coisas que eu coloquei pra entender com mais clareza o questionário, essa entrevista, tá? Então não fique tão assustado que eu vou entrevistar, mas é mesmo porque no questionário acho que o pessoal ficou um pouco mais tímido para responder. E teve coisa que realmente ficou faltando perguntar no questionário. Por exemplo, você chegou a estudar antes de vir estudar aqui no Centro Educacional Trandisciplinar, né? Pois você disse "sua "época de escola"”, então você já estudou antes.

J: Já estudei.

P: Então, onde? Quando tempo faz? Você poderia me contar um pouquinho sobre isso?

J: Em 1992.

P: Foi na idade normal, na idade escolar mesmo, criança e adolescente?

J: 17, 18 anos eu tinha. Mas eu sempre tinha dificuldades de estudo.

P: Dificuldade como?

J: Ajuda de família mesmo, assim, como se fala, incentivo.

P: Incentivo não tinha?

J: Não, eu tive dificuldade. Fui atraído a sair da escola e ir ao trabalho.

P: Dificuldade financeira também na família?

J: Também.

P: Porque você tinha que trabalhar para ajudar na família?

J: Isso, mais para isso do que... Dificuldade todos nós passamos, mas era mais por causa desse lado aí, de incentivo financeiro.

P: Como que era na escola? Você gostava?

J. acena com o rosto sinalizando que não gostava

P: Não gostava. Ia bem na escola?

$\mathrm{J}$ : No comecinho eu ia sim. Mas devido às amizades que eu formei, eu não acreditei nas amizades, então por isso que aconteceu isso comigo. Então fui atraído para o mundo. Comecei a trabalhar, parei de estudar, se envolvi nesse relacionamento. Com 16 anos já estava fugindo da escola. Mas até 15, 16 eu ainda estudei.

P: Que série você estava quando você parou?

J: Foi quinta (série).

P: Quinta, com 16 anos.

$\mathrm{J}$ : Por isso que estou retornando agora para essa série.

P: Então você começou aqui no Centro Educacional Trandisciplinar nesse ano ou você já tinha tentado voltar antes?

J: Voltei. Fiquei pouco tempo e trabalhando. Conforme o trabalho e o cansaço vinham, eu não aguentava, não tinha forças para isso.

P: Já no ensino para adultos? Ou você tentou no ensino regular, com adolescentes junto? Ou não?

J: Já tentei supletivo desde a idade em que eu estava, vai fazer uns 17 anos mais ou menos...

P: ... Que você parou?

J: De 16 aos 17.

P: E você é de São Paulo? Eu já tinha que ter começado a fazer essa pergunta.

J: Não.

P: É de onde?

J: Pernambuco.

P: Pernambuco? Qual cidade?

J: Petrolina, me criei lá.

P: Mas nasceu onde?

J: Nasci já no interiorzinho do sertão.

P: Só nasceu lá, se criou em Petrolina. Foi lá que você estudou até a quinta série?

J: Lá eu estudei até a terceira série. Só que, na terceira série, em 1991, fomos embora para cá.

P: Com sua família toda?

J: Isso.

P: Por quê? Até entendo que muitas famílias nordestinas vêm para São Paulo mesmo. Mas qual a história da sua família de ter vindo?

J: Foi a trabalho. Meu pai veio primeiro, ele trabalhava com tratores. Então, mexendo com trator, ele foi contratado para vir a São Paulo. Ele veio primeiro. Nós ficamos lá [no nordeste]. Ele veio fazer um teste e, se ele 
gostasse de São Paulo, o restante da família viria junto. Aí foi e eu vim, resolvi o que tinha para resolver e estamos aqui até agora.

P: Você veio para cá com quantos anos?

J: Vim para cá quando tinha entre 12 e 13 anos.

P: Então é isso. Você tem mais irmãos?

J: Tenho.

P: Quantos irmãos?

J: Tem mais dois, um que é mais velho e o a outra é minha irmã.

P: Que é mais nova?

J: Isso.

P: Então, você veio para cá e já emendou os estudos aqui em São Paulo ou teve que ter uma adaptação? Ficou sem estudar?

J: Não, cheguei aqui e teve aquele tempinho de espera para ver se encontrava vaga.

$\mathrm{P}$ : Antes era mais difícil encontrar vaga mesmo.

$\mathrm{J}$ : Isso, era mais difícil.

P: Então você teve apenas alguns meses provavelmente de espera. Não teve um intervalo. O intervalo mesmo de estudos foi depois, quando estava na quinta série já, né?

$\mathrm{J}$ : Isso.

P: O que levou você a voltar a estudar com mais força, com mais firmeza no Centro Educacional Trandisciplinar? Desde quando você está no Centro Educacional Trandisciplinar?

$\mathrm{J}$ : Desde a férias passadas agora.

P: Julho ou março?

J: Julho.

P: Sim.

J: É, eu peguei um mês antes delas, peguei antes das férias.

P: Então foi antes das férias de meio de ano.

J: Isso, eu peguei já 20 dias antes das férias.

P: A turma já tinha começado a ter aula?

J: Já. Foi no dia 25, eu lembro, foi meu primeiro dia de aula. Foi no dia 25 do mês 6.

P: Certo, então foi no dia 25 de junho, então estava próximo [das férias]. Bom, então o que levou você a retomar os estudos agora?

$\mathrm{J}$ : Olha, por falta de interesse mesmo.

P: Mas você está interessado.

$\mathrm{J}$ : Estou interessado.

P: Então por que você está estudando agora?

J: Por que estou estudando agora? Porque eu perdi muita coisa, nos estudos. Essa falta de tempo... e a minha vontade é essa: terminar meus estudos e procurar um objetivo melhor.

P: Que objetivo melhor?

J: Que seja uma faculdade e fazer o que eu quero fazer.

P: E o que é [que você quer fazer]?

J: Sei lá, porque eu já trabalho na área. Agora atualmente acabei de perder o emprego, devido a isso aí mesmo.

P: Você achou que podia ter aumentado sua chance de ter ficado nesse emprego ou podia melhorar, enfim, ir para outro emprego?

J: Ir para outro emprego.

P: Com que você trabalha atualmente?

$\mathrm{J}$ : Trabalhei muito tempo com comida.

P: Comida?

J: É.

P: Como assim? Fazendo [comida]?

J: Eu faço também. Atualmente eu só sirvo.

P: Sim, você é garçom?

J: Sim, eu sou garçom. Trabalho na parte da chapa também. Eu mexo com alimento, faço lanches, essas coisas e [trabalhei em] outras coisas, enfim, atendimento.

P: Já trabalhou em outras coisas nesse tempo? 17 anos, né?

J: Já sim, como ajudante de eletricista, ajudante de construção civil... Nossa, é tanta coisa que já fiz.

P: Na verdade, quando você tem menos escolaridade, você vai fazendo o que vai surgindo, né? Mas algumas pessoas acabam escolhendo, acabam ficando mais especialistas em algumas coisas. Não foi o seu caso?

$\mathrm{J}$ : Eu fiquei assim, não que eu quisesse trabalhar nessa área, mas integrar mesmo a experiência que eu aprendi e fazer a faculdade e fazer, na área de gastronomia. 
P: Gastronomia. Você é o segundo aluno que eu conversei aqui no Centro Educacional Trandisciplinar que quer fazer esse curso. Por que gastronomia? É com a experiência que você já tem trabalhando em restaurante e lanchonete ou tem alguma coisa a mais?

J: Não sei, mas parece que o que a gente pede, que vem tudo... quando a gente já está favorecido... o que eu quero dizer: com a aula de inglês, com o que eu pretendo fazer, que é terminar meus estudos com calma, pensando direitinho, direitinho, mexer com negócio de gastronomia, fazer a faculdade... não sei, de repente, vou trabalhar num lugar melhor, num hotel.

P: É, então pensando nisso...

$\mathrm{J}$ : Então, com a língua inglesa, eu pensava muito nisso aí antes, por isso estou focado no Centro Educacional Trandisciplinar.

P: O Centro Educacional Trandisciplinar ou os estudos?

J: Os estudos.

P: Os estudos... porque eu sei que o Centro Educacional Trandisciplinar... não sei porque você escolheu necessariamente... o Centro Educacional Trandisciplinar, ele tem um projeto diferenciado. Isso você sabe ou... você pensou nisso ao se matricular aqui - que o Centro Educacional Trandisciplinar tem um projeto diferenciado? Ou é por causa do horário, que é diferente também? Ou porque é perto da sua casa?

J: Na verdade, eu moro no bairro XXXXX. [O Centro Educacional Trandisciplinar] é perto de onde eu trabalho. Eu trabalho justo aqui. Então eu vou [ao Centro Educacional Trandisciplinar] de manhã, que é melhor...

P: É, porque é difícil escola ter aula para adulto de manhã.

$\mathrm{J}$ : Foi incentivo também de um professor, que ele conhece aqui e dava aula no XXXXX. Então foi incentivo. Você vê que o incentivo como o mostra o que a gente quer e o que a gente vai dar para trás. Então, poxa, incentivou... é o que faltou para mim na minha família. Também não critico hoje.

P: E também eles não sabiam da importância talvez. A gente tem as nossas próprias escolhas.

J: Com certeza.

P: Aham.

J: Então é muita falta dos estudos mesmo. Então... estou gostando. Já tive oportunidade, mas também me afastei devido a outras situações, mas estou focado.

P: Está gostando?

J: Estou. E está melhor agora. Com a professora Vívian.

P: A professora Vívian, eu não sei, ela envolve os alunos.

J: O T. também está ajudando bastante nessa parte, de conversar com a gente.

P: Eu nunca tinha visto uma aula dele, até porque estava passando o horário já da aula da Vívian, por isso que entrei e achei muito interessante, porque matemática eu sempre odiei. Eu sempre fui uma negação com matemática. Aí eu entendi umas coisas que eu não entendia. Eu não entendia, não! (risos) Muito interessante a abordagem aqui do Centro Educacional Trandisciplinar é interessante. Bem, até agora fiz algumas perguntas, já deu 12 minutos... umas perguntas mais gerais para saber da tua trajetória, do que você está achando dos estudos. E agora, a minha pesquisa... minha pesquisa é o seguinte: como sou professora de inglês, por isso que assisto às aulas da Vívian inclusive, a minha pesquisa é voltada especialmente para tecnologia, principalmente internet, tecnologia digital e internet. Você viu que a Vívian perguntou: "ah, estava pensando" que eu queria te contar um negócio que eu pensei em língua inglesa. Uma tecnologia que você mencionou mas que não é uma tecnologia digital é o rádio, que você gosta de ouvir. Então eu acho... eu não queria começar falando isso, mas eu acho que tecnologia e inglês têm muito a ver para você aprender...

J: Têm.

P: Você acha que tem alguma relação a aprendizagem de inglês com internet?

$\mathrm{J}$ : Tem.

P: Qual relação?

J: Relação assim, por exemplo...

P: Pode ajudar?

J: Pode ajudar nas pesquisas, descobrir o significado de uma letra...

P: De música, por exemplo..

J: Traduzir... acho que tem sim [relação]

P: Tem relação, né?

$\mathrm{J}$ : Tem relação.

P: Aquele questionário que você respondeu, eu não estou com ele aqui, enfim, então minha cabeça...

$\mathrm{J}$ : O que eu coloquei eu não poderia ter respondido, o que eu marquei.

P: Você tem computador?

J: Tenho. Notebook.

P: Notebook em casa, além das aulas que você tem aqui já, né, na escola? Então qual que é o uso que você faz?

Diariamente? Sites que você costuma acessar? Queria que você me contasse... qual que é o principal que você costuma usar computador? 
J: Então, eu peguei ele tem pouco tempo. Faço os trabalhos daqui.

P: Ah é? Então você comprou por causa da escola?

J: Também.

P: Também, certo.

J: E tudo o que eu pretender... abrir aquela parte da pasta, dos arquivos e me desenvolver nessa área, nessa parte aí. Mexi já com... procurar também, me incentivar na tecnologia.

P: Eu quando... para você ter uma ideia, eu terminei o ensino médio em 2001. Então tem 11 anos isso. Não faz tanto tempo assim, mas eu não tinha como disciplina escolar a informática e vocês aqui no Centro Educacional Trandisciplinar têm. As escolas da prefeitura, não do estado, mas da prefeitura, para a criançada e adolescentes, têm também. O que você acha? Por que isso acontece? Por que é que há dez anos atrás não tinha aula de informática e hoje tem?

J: Eu acho que é mais um incentivo para as crianças não desistirem dos estudos e se focarem nas tecnologias.

P: Então tem alguma importância a tecnologia.

J: Tem importância...

P: Para a educação.

$\mathrm{J}$ : Com certeza.

P: E como você vê a importância da tecnologia para a educação? É um incentivo e o que mais? Algo mais?

J: Também dá uma certa... mais educação também. Mais educação para o aluno não desistir dos estudos. Focar também porque... é muita coisa pedida. É uma questão de incentivo mesmo.

P: E qual a importância das tecnologias no mundo de hoje? Não só para a educação. A gente está falando de dentro de uma escola, então está mais direcionado. Mas e para o mundo de hoje? Assim, no dia a dia? Em outras relações, talvez econômicas, relações pessoais, como você vê isso?

J: A tecnologia está mais avançada na área de?

P: Assim, o que te vem à mente primeiro? Eu penso também de comunicação. A tecnologia tem bastante função para, além da educação, também para a comunicação, [para a] economia. Como que você vê? Me dá alguns exemplos do que você vê.

J: Mas eu acho que você já respondeu.

P: Por isso que eu não gosto de ficar dando exemplo aqui. (risos) Acabo influenciando as respostas.

J: Primeiro à mente também, é o que eu ia falar, mas aí...

P: O que você ia falar?

J: São essas duas... e...

P: Por exemplo...

J: Sei lá, também para o mercado de trabalho, a área do trabalho, na lan house, as pessoas focarem um pouco em pesquisas, em livros, ler, copiar, fazer cópias, enfim, tem muita coisa.

P: A gente está bastante rodeado com tecnologia.

J: Está muito rodeado.

P: Está muito rodeado, desde o caixa de supermercado, por exemplo, que hoje em dia o cara nem tem que digitar mais, é só passar no leitor ali, já sai, né... fazer uma continha ali. O próprio internet banking, enfim, mas acho que na internet o jeito (?) muda, as transações econômicas, isso muda os tipos de emprego que as pessoas têm também e comunicação. Tem um aluno que eu entrevistei semana passada que a família dele é do Piauí e ele se comunica de um jeito que ele não se comunicava antes, com muito mais frequência, pelo Facebook. Isso muda inclusive a relação que ele tem com a família dele hoje em dia. É, bom, para terminar, eu queria saber então dessa questão do inglês, talvez influenciado pela discussão que o pessoal teve hoje, queria que você comentasse a importância do inglês na sua vida e no mundo também. Então sempre tem essa comparação também. Se você acha que é importante...

$\mathrm{J}$ : Eu acho que para qualquer um é importante.

P: Por quê?

J: É importante por causa do trabalho, principalmente. Que nem eu falei para você, pretendo sim fazer o que tenho de fazer, arrumar um emprego e, com a língua inglesa, ela modifica muito. Ela dá acesso a qualquer lugar do mundo. Então o incentivo de aprender ela é muito interessante, que é através dela... é mais difícil, né, o inglês e o português. Então, sabendo falar português...

P: É, não é uma língua fácil de aprender, não (risos).

J: Não são todos também que falam a nossa língua inteira com perfeição. Mas o inglês... são as duas mais... acho que tem três, tem a do Japão.

P: É, o chinês também, que é a língua mais falada no mundo é o chinês.

J: É a mais falada e a mais complicada, de se aprender e de se escrever. Mas ela incentiva. Com o inglês, ela incentiva. Tem outras e outras. Mas para mim é importante, é muito útil.

P: E para o mundo? Ah não, acho que você já está respondendo talvez para o mundo, né?

J: Também. 
P: E na sua vida, como que você usa ou vê o inglês? É só na aula? Ou de repente você presta atenção em letra de música? Ou em filme? Ou até mesmo na internet, você de vez em quando vê alguma letra, alguma palavra, presta atenção nela? Eu queria saber como que o inglês está no seu dia a dia hoje.

$\mathrm{J}$ : Por enquanto acho que não estou bem focado, porque realmente estou tendo as primeiras aulas agora.

P: Isso é um dado interessante para mim inclusive, porque eu estou observando aulas de terceiro módulo.

$\mathrm{J}$ : Por isso que a gente tem que prestar atenção, eu principalmente, nas aulas da professora Vívian. Aí depois, prestando atenção nas aulas dela, focando nela, aí sim eu vou chegar em casa, vou lendo, que seja para mim ir desenvolvendo aos poucos e tem aqueles detalhes, porque... avançado demais a gente não aprende nada, correndo demais. Você tem o seu tempo dos estudos. É a primeira série, é a oitava. Então teve aquele tempo. Teve tempo de aprender. Só sabendo não sair da linha. Mas por enquanto eu estou iniciando e estou interessado. P: Verdade. É o prazo que você deu ao comprar... já estou fazendo uma relação já... ao comprar o seu computador. Agora lógico que você comprou por outros motivos, mas uma das primeiras coisas que você falou que foi por causa da escola, para te ajudar... a pesquisar, talvez, a praticar um pouco mais o que você aprende aqui. A mesma coisa com o livro, é uma tecnologia também, imagina, você fazer um papel, é muita ciência para poder fazer um papel. Transformar uma árvore num papel. Então são ferramentas que ajudam a gente. Você tem talvez estudado o seu livro, mesmo quando a professora só deu lá a primeira estrofe da música. Você já pensou, por exemplo, em ir lá, mexer um pouco mais?

J: Já.

P: Você tem feito isso?

J: Não, porque eu não vim essa semana. Eu não vim, mas eu faltei esses dias por esses problemas que eu estava resolvendo no serviço. Mas agora eu estou aqui com você, mais tranquilo, porque atualmente...

P: Senão você teria que ir embora! Por falar nisso... [olhando para o relógio]

J: Não sei você.

P: Tenho um compromisso às 4 horas agora só.

$\mathrm{J}$ : Você precisa almoçar e eu preciso resolver algumas coisinhas, mas tudo bem.

P: Aliás, eu tinha marcado meio dia e vinte, já é meio dia e trinta e um. Mas está bem, já respondeu todas as perguntas que eu queria ter feito, [você] está bem! Está ótimo! Tem algum comentário mais que você gostaria de fazer, alguma coisa que eu não perguntei e que você queria falar...

J: Eu acho que não sei, vai depender de mim. Eu não desisti.

P: Não desistir, exatamente.

J: Não desisti, vai depender de mim. Porque o que vem pela frente aí é só o que eu quero: é terminar.

$\mathrm{P}$ : E tem vários passos, né?

J: A faculdade também. Terminar os estudos direitinho, tranquilo. E aí sim partir para uma coisa que realmente... mas para isso tem que trabalhar um pouquinho com a mente até lá.

P: É verdade, é um exercício...

J: ... colocar as coisas nos mínimos detalhes, tranquilo, só com esforço próprio... Tem um pedacinho da letra da música que ela fala se ela fez assim, quando (?), é pensar comigo mesmo. Agora eu só penso comigo mesmo. Eu estou conversando com você aqui mas eu nem com a minha família eu converso.

P: É, né...

J: Não. Hoje eu sou um pouco reservado.

P: Mas eu não acho que é você, não. Até porque você é bem articulado, você já pensou nisso antes. Não é? Ninguém dá uma resposta que você está dando agora se nunca em algum momento da sua vida tivesse pensado. Eu acho que não é só você não que deixa de conversar. Você conversa com amigos também?

J: Poucos.

P: Também sobre essas coisas de planos para o futuro?

J: Não...

P: Essa é uma coisa que, na sociedade de hoje, também é muito difícil. É difícil você ter alguém com quem você fale sobre um lado mais pessoal, de sonhos, planos... Por quê? Porque ninguém quer saber mesmo, né? Querem muito mais falar de, sei lá, coisas mais distantes.

$\mathrm{J}$ : Por causa disso que, na minha trajetória de viver, eu dei muita atenção para pessoa que eu não devia, e acabei me...

P: E acaba te desviando dos seus objetivos.

$\mathrm{J}$ : Por isso que eu não tive cabeça para isso. Hoje, sim. Eu precisei saber de um tempo para mim... para fazer uma lavagem, uma limpeza... de tudo, para retomar tudo aquilo que eu não deixo de tirar da minha cabeça o que eu quero.

P: É verdade. Quantos anos você tem?

J: 34 .

P: É, então, não... não perdeu tanto tempo assim, não. 
J: Não perdi tanto, não. Mas eu precisei de ficar assim uns dois anos e meio fazendo essas limpezas do que eu quero e o que não quero e, enfim... estou comentando com você o que eu prometi de falar para você, eu tinha esquecido.

P: J., gostei bastante das respostas, achei que entendeu bastante as relações que têm. Mas acho que também porque você pensa bastante sobre essas coisas e já tem objetivos na sua vida. Então já adiantou bastante. As minhas perguntas talvez já tinham bastante a ver com o que você já costuma pensar mesmo. Então legal, J., é uma contribuição de bastante interesse para a pesquisa, dados importantes, tá. 


\section{Apêndice 12 - Entrevista com Milena (feedback final) em 13 de dezembro de 2012}

P: Então, retomando algumas coisinhas, eu queria saber então, eu me lembro mas é bom gravar novamente, sobre a sua formação.

M: Bom, eu sempre estudei em escola particular, prestei letras em 2004, passei na primeira chamada na USP, e fiz bacharel em cinco anos, e durante a graduação eu participei em dois projetos de iniciação cientifica, um eu tinha várias ideias e não conseguia decidir o que fazer, tinha que afinar muito e eu tive dificuldade, eu acabei me envolvendo com um projeto de pronome de tratamento do meio universitário, nós fizemos em grupo, tinha pesquisa de campo, e nós saiamos pelo campus da USP fazendo um monte de perguntas para o pessoal.

P: Você fez essa trabalho só na Letras?

M: Não, não foi na letras, eu fiz na química e na veterinária. Conheci muita gente legal nessa época, era utilização de pronomes de tratamento, pronome de tratamento no meio universitário jovem, algo do gênero, era bem legal, mas nada a ver com o que eu fui fazer depois, ai depois eu fiz iniciação com bolsa em literatura brasileira, analisando a Carolina de A Moreninha com a Morena de Senhora, amei de paixão, foi a época que eu comecei a gostar de Alencar, Alencar é difícil, gostei da pesquisa, até pensei em trabalhar com isso posteriormente no mestrado, mas mudei de ideia, mas ainda gosto muito dessa coisa de figurar feminina, de construção de identidade Me formei no final de 2009, 2010 eu fiz uma pós, formação docente para o ensino superior na XXX, gostei..

P: Foi de um ano a sua pós ou de dois?

M: De um ano. E eu não sabia o que fazer de mestrado, no mestrado eu teria que ter um cargo só, eu teria que me dedicar, deveria levar muito a sério, eu teria que ter tempo e disposição, e eu não tinha nenhum dos dois, e nem ideia do que eu queria fazer.

P: Achou melhor esperar um pouco, amadurecer melhor?

M: Exato, ai eu fiz uma coisa bem abrangente, porque o meu negócio é trabalhar em faculdade, a médio e a longo prazo, gostei do curso eu aprendi bastante coisa, isso foi em 2011, porque em 2010 eu fiquei parada nesse sentido. Dois mil e onze foi o ano passado, fiz um curso de um ano, apresentei TCC, o TCC ficou legal, era um artigo, sobre a importância da pesquisa no meio universitário, ficou bem legal, eu gostei bastante, e ai o ano passo eu decidi que eu queria fazer uma coisa um pouco mais especifica voltada ao inglês, e esse ano de 2012 eu comecei no XXX, eles tem essa parte de pós aqui em São Paulo também, o tema é O ensino de Língua Inglesa e o uso de novas tecnologias, eu estou adorando o curso, então ele com o foco voltado para gramática, uma gramática bem complexa, profunda, com professores nativos, então eu tinha professores de Trinida e Tobago, professor Inglês, então você tem gírias, você tem estrutura gramatical, bem aprofundado, eu gostei muito. Depois nós passamos faz uns três meses eu acho, por que essa pós é um final de semana por mês, nós passamos justamente para essa área de ensino, então por exemplo, habilidades receptivas, habilidades ativas, não, não é o termo é correto, então tem as habilidades ativas e as outras que eu esqueci o nome, então é a diferença entre (?) a diferença de tudo, está parte de ensino está bem aprofundado também, e eu estou adorando, e esse terceiro momento momento que eu acho que vai ser só o ano que vem, que é a parte das tecnologias, que já deram uma adiantada para gente, discute como podemos usar o Facebook ao seu favor, como utilizar as Wikis, no curso que eu fiz na XXXXX de formação docente, nós tivemos também umas matérias chiques, então eu tenho uma base mais bem superficial, eu imagino que agente vai uma uma aprofundada nessa outra pós.

P: Teve uma coisa que você postou no Face, isso é uma porcaria né, quando agente adiciona as pessoas no Face, você colocou EAD não é para mim, por que?

M: Porque eu estou fazendo, que não tem nada a ver com educação, maravilhoso, pela XXX, universidade livre da XXX, de Editoração, é meu plano B, se tudo tudo der errado na educação, se eu ficar surtada...

P: Você está fazendo dois cursos ao mesmo tempo?

M: Sim, sim, é porque esse não é de pós, é um curso livre de curta duração, então é de setembro até dezembro agora, vai acabar eu acho que essa semana que vem. Então é assim, eles são extremamente organizados, é uma aula por semana, agente tem uma semana para ler os textos e para assistir os vídeos da Laura Bacelar, que é fantástica, e eu tenho as atividades, mas assim, você tem que ter uma disposição e uma disciplina que eu não tenho, eu tenho disciplina por exemplo para preparar as minhas aulas, para fazer os meus diários, eu tenho disciplina por exemplo para aulas que eu vou ter na pós, fazer um curso totalmente em EAD comigo não funciona, eu não sei se é uma coisa minha, se é porque eu não tenho um grau de maturidade adequado, mas eu acho que é uma coisa minha mesmo. Eu preciso de ir, estar de corpo presente, não é nem as questão do professor cobrando, não é nem isso, eu preciso me locomover, não sei!

$\mathrm{P}:$ Eu acho que não é só você não, eu acho que é uma pratica que tem que envolver outras pessoas, estudar é isso, é trocar.

M: E a gente tem os fóruns, eles são ótimos, o pessoal é super ativo, mas não dá, eu não tenho paciência por exemplo de ficar postando e lendo tudo, eu não tenho tempo, eu acabo usando o meu tempo na internet para outras coisas. Ai eu lembrei que quando eu estava na USP, a professora Valquíria e o professor Ninmário tinham os grupos e fóruns no Yahoo, e eu comecei super empolgada e depois já não aguentava mais 
P: Eu também me lembro, nesse semestre eu resgatei algumas coisas desses fóruns, do Linmário e da Valquíria principalmente, quanta coisa que eu perdi, eu não acompanhei.

M: Era útil, era importante, mas não dá, comigo não funciona. De modo nenhum é a questão da organização, o tutor é bom, a professora é boa, que no caso é a Laura Bacelar é excelente, o curso é maravilhoso, super bem organizado, mas o negócio é comigo, eu não funciono $100 \%$ em EAD, eu preciso de alguma coisa presencial sim.

P: E no curso da XXXXXX então tem uma vez por mês, você consegue fazer uma recapitulação você está presencialmente lá, você acha que nesse esquema, com pelo menos uma parte do curso seja melhor?

M: É que no casa da XXXX é assim, um fim de semana por mês a gente vai lá e tem a aula, eu acho que assim é melhor, comigo funciona muito melhor, e assim é claro, as atividades e as provas são todas online, então eu fiz uma atividade, uma plano de aula para uma matéria, sensacional a professora, fiz o plano de aula, mandei para ela online, e todo o material fica disponível online, eles mandam link tudo, mas assim, o curso é presencial, você tem que acessar a internet para você fazer as atividades, é obvio, mas é presencial. Tem chat por exemplo, por exemplo agora vai ter um dia 18, de noite tudo, com a professora, das atividades receptivas, mas ai é que tá, não é online, não é EAD, EAD puro, o negócio é EAD 100\%, comigo não dá.

P: Eu gostaria de saber também porque você escolheu dar aulas na Prefeitura?

M: Na verdade foi uma aventura, eu e meus colegas estávamos no ultimo ano de faculdade, e abriu concurso para a prefeitura, e nós fizermos a prova para ver como nós estávamos, para ver como era, nenhum de nós tinha planos de ficar na prefeitura, de passar no concurso, nenhum de nós tinha essa pretensão, acontece que nós éramos em quatro e os quatro passaram, e foi mais ou menos assim, vamos ver o que vamos fazer, vamos ver no que vai dar, realmente foi uma aventura, eu escolhi essa escola por que era muito próxima da minha casa, eu não tinha referencia, porque se fosse para eu passar no concurso e dar aulas em uma escola longe da minha casa eu não ia topar também, eu não tinha carro, e minha pontuação eu não lembro qual foi mas não foi das melhores, eu não vou me meter lá no meio do nada sozinha, e de repente ter que dar aulas a noite, escolhi essa aqui por causa da proximidade, uma das nossas coordenadoras eu já conhecia de outro lugar, a diretora dessa escola foi a minha professora de biologia no ensino médio, eu me senti muito em casa, mas foi um choque para mim. Um choque porque a escola para mim foi um choque, por que na faculdade por mais que eu tenha adorado e tenha me preparado relativamente bem, a parte da licenciatura acaba deixando um pouco a desejar, eu acho que a pratica não tem nada a ver com a teoria que eles colocam lá, e eu sofri um bocado, um sofrimento num bom sentido, mas não foi só aqui, porque eu comecei a dar aulas em uma escola particular aqui perto também, o choque que eu digo não é por ser escola publica, o choque da escola publica eu tive em 2009 quando eu fui estagiar, por que eu lembro que eu fazia estagia de $5^{\mathrm{a}}$ e $6^{\mathrm{a}}$ de manhã em um monte de escolas aqui da região, e durante a noite eu estava fazendo cultura inglesa, eu estava estudando lá, e eu me lembro que me sentia muito mal no sábado de manhã, porque na sexta de manhã eu fazia estagio, e eu não gostava da escola que eu fiz estágio, eu fui muito bem recebida, mas assim, eu não gostava do clima, do ambiente, da energia, me sentia mal lá dentro, embora os professores fossem ótimos, me ajudaram, me acompanharam, mas eu não me sentia bem.

P: Mas o que tinha, as aulas dos professores eram ruins?

M: Não, não, não, era uma coisa da escola, sabe quando você entra num lugar e não se sente bem, ara por ai, corredor muito estrito, escada muito estreita, salas com grades, e aqui você não tem isso. Então eu lembro que eu não me sentia bem, era uma pobreza, uma miséria, uma carência de tudo, eu lembro que nós tínhamos um aluno lá, eu me lembro até do rostinho dele, era sétimo ano, era um mocinho, e ele tinha algum tipo de necessidade especial, ou alguma coisa mental que eu não sei te dizer o que é, eu sei que ele passava a manhã inteira babando sobre o caderno dele, ninguém conseguia fazer nada por ele, eu não conseguia fazer nado por ele, e aquilo me deixava triste, muita pobreza, muita pobreza, muita pobreza, e ai eu ia estudar a noite na cultura Inglesa e as crianças com aqueles Ipad, com aqueles Iphone, e é um outro mundo, me incomodava muito. Uma coisa que eu me propus a fazer é não largar a prefeitura para não esquecer o mundo real, por que para mim isso aqui é o mundo real.

P: Como assim o mundo real?

M: Por que se você pega, eu acho tá, é uma coisa minha, posso estar enganada, acho muito fácil você pegar uma escola boa, de uma classe média mais alta, e você se acomodar, e você achar que aquilo é o aluno, aquilo é a escola, aquilo é a vida, e você se alienar do resto. Que você achar que ensinar o verbo to be, "nossa, você está fazendo muito por seu aluno", tudo bem, vai ensinar o verbo to be vai, mas as vezes existem outras coisas que as vezes passam pela educação que agente deixa passar, que são fundamentais, então por exemplo, não tivemos festa de encerramento como eu comentei com você, formatura do $8^{\circ}$ ano da EJA, foi lindo, eu chorei, eu abracei meus alunos, eu vou sentir falta, eu percebo que embora em tenha preparado minhas aulas de inglês, eu tenha me esforçado tal, e eles tenham na medida do possível de cada um, eles tenham adquirido alguma coisinha, ficou muito mais os valores, o que eu passei que não era curricular, o que eu passei, isso, eu percebo que ficou. E às vezes eles não tem isso, então eu sinto eles muito carentes de tudo, e eu sinto que eu tenho alguma coisa a oferecer. 
Eu lembro de que quando eu estava na USP aconteceram alguns eventos, e eu lembro que eu não gostei, a mulher era uma bambambam da educação e falou assim, por que o professor que faz faculdade publica ele tem o dever de trabalhar em escola publica, pra digamos assim, pagar...

P: A gente escuta muito isso

M: Olha, eu acho que não, colocar isso como uma obrigação eu acho muito complicado, por que eu estudei em escola particular a minha vida inteira, embora eu tenha feita uma faculdade publica, mas eu entendo um pouco mais do que ela quis dizer, na verdade eu acho que todo mundo deveria se propor a tentar pelo menos, só que é difícil você colocar isso como uma imposição quando você vê condições muito adversas, teve um amigo meu que passou comigo, ele pegou português e Inglês, consegui na mesma escola, e ele não aguentava, era uma escola barra pesada, em XXX, não dava, ele estava ficando doente, e você vai falar o que, "não, você tem obrigação...", não é assim, esse ano de $2012 \ldots$, eu sou um ser humano, até onde der para ir, da para ir até aqui ótimo, eu faço tudo que eu posso, tendo as minhas limitações de falta de experiência de falta de conhecimento em algumas áreas, não digo nem o conhecimento de língua, eu digo o conhecimento de sala de aula, como eu falei para você, licenciatura foi legal mas deixou muito a desejar, eu senti falda de um monte de coisa. E coisas bobas, como por exemplo como preencher um diário de sala, eu nunca tive uma aula oficial sobre como eu preparo um plano de aula, e é meio sério isso, é bem sério.

P: E como você acha que isso é sério, de atrapalhar, de ajudar?

M: Por que é básico, por que as discussões filosóficas que eu tive na faculdade eu não vejo como eu consigo aplica aqui, por exemplo, eu gostaria muito, é obvio que não tem nenhuma receita, mas eu gostaria muito que alguém me desse uma diretriz de como devemos lidar com o aluno com aluno agressivo em sala de aula, trabalhei em uma escola particular que o aluno me levantou a mão, por muito pouco ele não me bateu, aluno de $7^{\circ}$ ano, maior do que eu, quando eu olhei aquilo eu falei, “gente, foi pra isso que eu estudei”, uma coisa é você ser paciente com o aluno, uma coisa é você negociar com ele, você está lidando com adolescente você sempre vai ter que negociar com ele, não adianta você gritar, ficar histérica, ter chilique, você vai ter que negociar, agora quando o aluno levanta a mão para você você não tem negociação, você tem um problema muito sério.

P: E como você vê essas questões conflituosas, essas lacunas que você teve na sua licenciatura na USP quando você ministra aulas para os adultos?

M: Adulto eu acho muito mais tranquilo, porque o que eu sinto com o adulto, no caso de EJA, não estou falando para um executivo, é a questão do acolhimento, então assim, primeiro você vai construir no seu aluno a questão da confiança, mostrar que ele é capaz, mostrar que o inglês por mais que não pareça faz parte do mundo dele, toda vez ele come hambúrguer, ketchup, que ele ouve alguém falar de personal trainer é inglês, então faz parte do mundo dele, ainda que não esteja tão próximo, então quais são as medidas iniciais, mostrar que o aluno está familiarizado sim com o inglês, construir a confiança desse aluno, acolher esse aluno, trazer ele para perto de você, e a partir dai ver o que que interessa pro aluno, entendeu? Então assim, eu trabalho muito com vocabulário, algumas estruturas, no caso de terceira etapa.

P: O que o seu aluno de EJA precisa saber de inglês? O que te direciona a escolher o que ele precisa saber?

M: Olha, eu me importo com duas coisas, primeiro em relação as expectativas ao $5^{\circ}$ e $6^{\circ}$ ano, que é o equivalente as expectativas de EJA, algumas de EJA cabem bem e outras não, tanto que nós tivemos, esse ano nós não usamos, mas o ano passado nós tínhamos, os professores tinham livros pra EJA, especifico, então o inglês por exemplo era um livro começava super legal, apresentação, mas chegava a um ponto em que não dava mais para seguir.

P: Por que?

M: Muito avançado. Então eu prefiro mil vezes, como eu fiz com $4^{\mathrm{a}}$ etapa, que é $7^{\mathrm{o}}$ e $8^{\mathrm{o}}$ ano, eu fiquei, gramatica o que foi, simple past e future - will e going to, eu preferi me apegar a esses dois pontos gramaticais do que ficar colocando past continuous para eles. Então eu prefiro muito mais trabalhar menos conteúdo que de repente vão se solidificar um pouquinho mais, do que entrar com muita coisa que eu acho que vai se perder e eu acho que vai complicar, eles vão ficar inseguros, mais do que eles naturalmente já são em relação ao inglês.

P: É, eu vi muito isso mesmo, bastante insegurança em relação ao inglês.

M: Por mais que você trabalhe, o discurso deles é assim, você deve ter ouvido, "eu não falo nem o português...." até o XXX disse isso e eu falei " você está falando em que língua comigo, porque eu estou te entendendo completamente", ai ele deu uma risadinha e eu falei, "está vendo?". Por que eles acham que falar o português é falar e escrever o português segundo as norma culta do professor Pasquale Cipro Neto, não é, mas é isso que eles acham. É massificante desde sempre. Então eu gosto de trabalhar muito a questão de registro com eles, do mesmo modo que eu tenho o português formal e informal, eu vou ter no inglês, e eu arrisco a dizer para eles que em qualquer língua eles vão ter isso. Você vai ter diferenças nos papeis sociais, então você vai ter que, ter que é modo de falar, preferencialmente você vai ter que se comportar e falar de acordo, vai ser um bom falante, o XXX de XXX falava isso, ele não, os teóricos falavam isso, que o bom falante do português é aquele que sabe se adequar ao ambiente, ao seu papel social, ponto fechou. E é isso que eu falo para eles, em relação ao inglês é a mesma coisa. Embora eles não vão explorar grandes questões de registro em inglês, mas é para eles saberem que existe também, então é diferente eu falar I ou eu falar ??hello, good morning, how are you? 
P: E como você vê então dele saber se adequar, a questão da inclusão, por que o que eu vejo de EJA é a questão do acolhimento, primeiro dele saber que é capaz de certas coisas e se valorizar, diversas trajetórias desses alunos mostram que eles estão estudando por diversos motivos, principalmente porque eles querem aumentar as chances deles, isso é o mais geral, eu escutei muitas histórias que não é nada disso, mas enfim, eles querem aumentar as chances deles, no que você acha que o inglês, saber dessas coisas aumenta as chances deles, nesse mundo que tem tecnologia e está globalizado?

M: Assim, vai depender do que eles almejam. Alguns querem fazer faculdade. Um aluno da $4^{\mathrm{a}}$ etapa quer ser professor, ele é um ótimo aluno. A princípio, eu tenho muito claro para mim que o inglês que eu ensino aqui para eles não vai ajudar ninguém a conseguir um emprego melhor. Infelizmente, não dá. Eles teriam que fazer um curso. É para eles saberem que o inglês existe. Que ele veio para ficar, que o mandarim dificilmente vai se sobrepor ao inglês por causa do alfabeto, porque a estrutura é muito diferente.

P: Então, que inglês é esse que você está ensinando? Por que motivo ele é ensinado?

M: Eu tento buscar coisas que sejam relevantes. Então, vocabulário, com a 3 etapa. O que eles teriam que aprender, segundo a legislação tal. Dias da semana, meses do ano, família. Aí aparece, "como é madrasta?" “como é divorciado?". Não adianta eu querer falar sobre efeito estufa com eles. No material do ensino regular, o $8^{\circ}$ ano, o livro é muito pesado para eles, tem textos muito longos. Eu não vejo, desculpe, a relevância de o aluno do $8^{\circ}$ ano saber o past perfect. E saber coisas, sei lá, sobre a revolução russa em inglês. Não. Não vai.

P: Você ensinou alguns temas. Por exemplo, quando você falou sobre energia com eles.

M: Isso aí era um projeto da escola. Todos os professores estavam falando disso. Aí, isso é diferente. Aí, você puxa pra eles, sempre puxando deles. Outra coisa, a cidade. A cidade, as profissões. Aí você puxa pelo bairro. Se eu for forçar alguma coisa, tem que ser alguma coisa que tenha a ver com eles.

P: Como você viu a experiência da música "Strange Fruit"? Como você preparou, como você percebeu a devolutiva, qual era o seu objetivo?

M: Eu queria passar alguma música para eles.

P: Por quê?

M: Porque é diferente. Na última aula com a $3^{a}$ etapa, em uma atividade de feedback final, teve uma senhora que pediu mais aulas com música. Eu queria trabalhar com música com eles, mas eu fico muito insegura porque eles são muito inseguros. Eu tenho medo de eles travarem, de eles ficarem com medo. Mas pensei, "vamos tentar, fazer uma coisa diferente". Tinha que ser alguma música lenta e que tivesse alguma relevância. Eu comentei com o pessoal, nossa equipe é muito boa, que eu adoraria passar essa música. Alguém falou "o dia da consciência negra está aí, você podia passar". Passei para $7^{\circ}$ e $8^{\circ}$ ano e EJA. Expliquei o que a gente ia fazer, mostrei as palavras.

P: Eles gostaram. Teve aluno que falou que ia procurar a letra da música na internet.

L: Eu gostei. A questão do listening foi difícil mesmo pra eles, de entender as palavras, claro, cada acerto foi valorizado. Expliquei, isso aqui não é prova, é a primeira vez que vocês fazem esse tipo de atividade. Então, eu não espero, como eu falo às vezes, não quero que ninguém saia falando fluente, nativo. É vocês saberem que existe, que faz parte do mundo de vocês e, claro, aprender o que puder ser absorvido. Maravilha. E foi a ideia da música também.

P: Como você vê o trabalho com o texto? Você acha que é uma dificuldade com os alunos? Você prefere gramatica? Dá para separar o trabalho em texto, gramática e vocabulário?

M: Olha, eu gosto de sistematizar gramática porque eu sinto que é uma facilidade que eles têm. Tem que escrever na lousa "Gramática", "Vocabulário", "A família", "A cidade”. Nesse sentido, você tem que ser bem didático. Eu como pessoa consigo ensinar e aprender desse jeito. Mas eles precisam de tudo bem preto no branco.

Eu gosto de trabalhar com gênero. Carta, receita. Até mesmo como confidence boosters, para assegurar a confiança dos alunos. mas também é preciso sistematizar. Eles precisam muito.

P: Senão, o que acontece?

M: Você já deve ter presenciado em algumas aulas... (dá o exemplo de alunos que parecem não saber ou não querer aplicar o que foi ensinado a outros contextos, mesmo que esse sejam muito semelhantes aos da aula).

P: falo do Ivaldo

M: O negócio de escolha, sempre faço meu planejamento e muda tudo. Quanto eu vi o ritmo. Eu não diria que é nivelar por baixo, é você mudar as suas expectativas e ver o que você pode fazer por aqueles alunos.

Tem um aluno, o P., que está na $4^{\text {a }}$ etapa. Ele foi meu aluno no ano passado, foi alfabetizado aqui. No ano passado, nós trabalhamos bastante com os alimentos. Ele é carregador de feira e fez um comentário que me garantiu o ano. Ele disse que viu escrito em uma caixa "apples" e lembrou de mim. Ele disse que lembrou que apple era maçã. Isso foi relevante para ele. Essa é a linha que eu sigo, tem algumas coisas que eles colocam nas diretrizes, "tem que ser assim". Ai, não tem que ser assim, você não sabe quem é o meu aluno, eu sei quem é o meu aluno. Eu mudo o planejamento, ponho coisa a mais. 


\section{Apêndice 13 - Entrevista com professora Vívian (feedback final) em 14 de dezembro de 2012.}

P: Antes de te conhecer eu sabia que você seria uma ótima referência para mim de aprendizagem, de professora, uma profissional. Não sei se você sabe, mas eu comecei a dar aula em ensino regular esse ano. Tenho oito anos de experiência como professora de Inglês em escola de idiomas. Com ensino regular, esse ano, mas eu saí por causa da bolsa. Mas enfim. Achei interessante ver aulas de professoras de ensino regular.

$\mathrm{V}$ : (risos)

P: Eu tinha visto em Português, na licenciatura em Português. Inglês, não, em Inglês o meu estágio foi regência com crianças, então foi uma coisa diferente, lá na USP, foi na USP. Enfim, é isso. Só para justificar algumas coisas, certo, Vívian? Bom, primeiro o que você prefere, que eu te pergunte primeiro ou que eu te conte essas impressões primeiro?

V: Você que sabe.

P: Então eu vou te contar. Uma coisa que eu percebi foi que os alunos, eles aparentemente se sentem mais à vontade com a informática do que com o Inglês, mas eu acho que isso não é novidade nenhuma. Então assim, essa é a primeira coisa bem superficial até, essa observação minha. Eu conversei com a D. uma vez ela me pegou de supetão.

$\mathrm{V}$ : (risos)

P: "E aí, o que você achou?" Eu falei: Olha, a única coisa que eu tenho para falar é isso, né. Nem falei isso para a Vívian ainda, mas eu precisava falar. Que eles ainda se sentem um pouco desconfortáveis, que alguns deles já compram, compraram computador. Inclusive, o J. comprou um computador quando entrou na escola, a E. também comprou um computador quando entrou na escola. Então, assim, mudam a atitude porque eles acham que é um investimento para eles, né, pessoal. Agora, o Inglês, mesmo com o computador, que eu acho que é uma ferramenta de aprendizagem para qualquer coisa, Inglês inclusive, não. Inglês já está um pouco mais distante, eles têm um pouco de resistência, uma dificuldade maior. Então, como eu não pude observar outras aulas, eu não sei se é uma atitude que eles mantêm com tudo, às vezes eu acho que é assim também, que é uma dificuldade, a baixa autoestima, a "vida" que leva eles a crer que eles não conseguem. Então, o trabalho de vocês é muito de desconstruir isso, né. Desconstruir esse imaginário de que eles não têm capacidade. Não! Muito pelo contrário! Mas é que o Inglês é difícil mesmo para desconstruir porque não está na vida deles ainda. Está na escola, mas não está na vida.

V: Eles não percebem que está no mundo, né.

P: Mas aí a capacidade do professor de tentar trazer isso para eles, né. Então eu lembro muito de você esse dia da aula com o violão, você conversando com eles. Eu até falei nessa aula, eu não aguentei e quis falar, "Olha, gente, o radinho. Funciona muito bem você ouvir uma Alpha FM e escutar as músicas, pelo menos, né."

V: P, eles escutam.

P: Mas não sentem que isso é um jeito de ter contato. Não sei se de aprender Inglês, mas de ter contato com Inglês.

V: Logo que eu vim para cá, foi uma coisa que me assustou muito. Porque eu falei, "Poxa, vida! Quinta série ama Inglês na escola!". Ah, não, depois eu falo, melhor você terminar.

P: Não.

V: Não vai atrapalhar?

P: Não, não, eu já... Tem uma outra coisa também, mas isso você já pode comentar.

V: Está certo. Esse negócio das quintas séries, né. Quando eu vim trabalhar aqui, eu lembro que eu estranhei demais porque para eles as aulas eram de Português e as próprias professoras só davam aula praticamente de Português. Inglês era no geral, assim, uma cultura da escola. A necessidade da alfabetização era tão grande, mesmo a quinta série, que priorizava-se a língua materna. Então sabe o que se ensinava de Inglês por ano, o ano todo quando eu entrei aqui? Números, cores, dependendo do módulo, profissões... Era lista de palavras. Está entendendo? Eu lembro que ficava o bimestre inteirinho, a única coisa que era trabalhada era partes do corpo, mas sem ligação com nada.

P: Sem ter uma coisa que se prolongasse.

V: Sem ter uma referência também de onde a gente pode encontrar isso na vida prática real, de onde eu posso usar isso. Então não tinha nenhuma conexão com a realidade. Eu lembro que eu fui trazendo algumas ideias. $\mathrm{O}$ pessoal era muito, muito fechado, minhas colegas que ainda estão aqui trabalhando comigo hoje em dia, aí depois de mim entraram dois professores que tinham uma visão mais aberta. E aí, algumas das nossas amigas que já estavam aqui também ampliaram a visão delas. Começaram a falar, "É verdade, a gente pode dar..." "Ah, mas eles não vão saber". Tipo, eles não sabem nem ler e escrever em Português direito. Olha só, os professores. Isso é fala de professor. Que estão aqui ainda. Não estou criticando, estou falando que é uma visão.

P: Uma visão que está difundida, né.

V: Que está difundida e foi difundida em tantos anos de escola que a gente vê aqui. Então, por exemplo, eles não sabem nem ler e escrever. A gente dá o basiquinho, só uma visão. What's your name, números e cores, isso já está ótimo para eles. Bom. Eu falei, "Gente, e o trabalho com texto, que está tão em voga hoje?" 
P: Era disso que eu queria te ia perguntar, o trabalho com texto.

V: E o trabalho com texto? "Ai, Vívian! Você é maluca? Dar o texto em Inglês para os alunos? Eles vão se assustar!". Eu falei, “Tudo bem! No primeiro ano eles vão se assustar. No segundo ano, eles já vão mudar”. "Ah, eles só ficam dois anos aqui com a gente". "Não faz mal. São dois anos que você vai plantar sementes". É a mesma ideia do filme. É a mesma ideia também para eles para informática. Os filmes ainda não mudaram a cabeça. Nós não conseguimos ainda mudar muita coisa na cabecinha deles quanto abertura de ideias. Não é mudar para defender nosso ponto de vista. Nós não temos essa ideia de querer mudar a cabeça deles para o nosso ponto de vista. Tanto que a gente não sabe nem se o nosso ponto de vista é o certo.

P: Exatamente. E pouco importa se está certo ou errado, também.

V: São probabilidades de estar certo ou errado, são probabilidades de visões diferentes. Mas é importante que eles tenham essa abertura para assistir a um filme, tanto que nós temos um projeto para o ano que vem já e vai ser sobre filmes. Nós vamos tentar filmar peças de teatro e eles vão montar um curta para o ano que vem e eu quero que também tenha um curta em Inglês, só que não tem ainda. Lógico!

P: Tem que almejar essas coisas, mesmo que seja difícil.

V: Mas aí tem que ser bem assim. A gente tem que ser muito cauteloso. Eu às vezes, no meu entusiasmo, acabo não sendo cautelosa. Eu acabo jogando a ideia e "Gente, assim!" (com entonação de entusiasmo). Entendeu? Mesmo com os alunos. Eu percebo que aqui há uma realidade tão diferente que a gente não pode ter aquela mesma... que a criançada. Que a criançada é assim, você e "Gente! Nanananana..." e eles, nossa, com a nossa euforia, conquista rapidinho. Agora, aqui já não. Aqui eles se assustam. É outra coisa. É outra realidade. Tudo que é novo assusta. É o que é mais ou menos aceito. É o que mais ou menos circunda por aí. Então, daí vendo que filmes não são bem aceitos, vendo que a Língua Inglesa já não é bem vista como tão importante nem pela classe e a informática é deixada totalmente à par até uns anos atrás. Ela era facultativa, depois ela passou a ser disciplina dentro da carga horária. Já melhorou. .

P: Isso veio da escola ou uma coisa geral, Vívian, a informática virar disciplina?

V: Do geral, da Prefeitura, geral. No Estado também. Não tinha informática. Há uns anos atrás é que veio ser implantado, não sei em que ano. Mas depois de 2000. Agora esse novo século, 2000 em diante, a gente vê que a informática começa a ser valorizada tanto que a tecnologia, ela está aqui presente do nosso lado, então foi meio que obrigado. Se não tivesse a informática na escola, a escola estaria mais atrasada ainda. Então até para a escola se considerar atualizada. Tem muito dessa ideia. Se a gente for considerar filmes. Se for pensar, até na escola regular a criançada acha que filme é o que, passar o tempo. "Ô professora, põe um filme aí. Não, a professora vai dar aula de filme." Ainda tem essa visão de que filme não é aula. A informática começou agora a ser mais bem vista porque os alunos querem aprender a mexer com as coisas e eles já estão começando a conseguir aquela curiosidade. Isso ajuda muito na educação. Quando a gente consegue despertar a curiosidade deles para algumas coisas, a gente parece que atiça. Eu uso muito a curiosidade como um recurso. E também uma coisa que assim, a sociedade, como a sociedade interfere. A sociedade está valorizando. Aquele cara que tem uma formação que tem especialidade em informática, mesmo que seja um Word básico, ele vai ter um cargo legalzinho, melhorzinho. Hoje em dia não tem mais datilografia, é digitação e Word, o pacote do Office, né, básico. Então você como a própria sociedade privilegia a informática e não a língua. A informática também é um meio de comunicação. Na informática, você consegue traduzir um texto primeiro. Olha como mudou a visão da criançada. Hoje em dia eles não têm mais dicionário. Juro!

P: Vai para o Google, né.

V: Google Tradutor.

P: Mas você acha que os alunos também conseguem, eles fazem esse uso de dicionário, de tradutor?

$\mathrm{V}$ : Eles usam, mas é raríssimo.

P: Não, é mais difícil de usarem.

V: É muito difícil. Primeiro porque não há realmente um interesse. A gente ainda não conseguiu cultivar para o Inglês o mesmo interesse que a informática tem. Começa daí. Além de outros fatores.

P: O que eu para a D. tem a ver com isso. De que Inglês é uma disciplina escolar.

V: Só serve... É igual História, Geografia.

P: É igual História e Geografia, é.

V: Agora o Português e a Matemática, não. Estão na vida. Olha o que eles falam.

P: Falam que o Português está na vida?

V: Falam que o Português e a Matemática estão na vida.

P: Que legal.

V: Eles falam. Isso daí faz anos, desde que... Professora, Português, para ler texto, para procurar num jornal um emprego, preencher a ficha de emprego, para você fazer um teste para um concurso público, para você poder achar o lugar aonde você vai no ônibus e ler uma receita, ler uma bula de remédio e eles falam também de no trabalho poder preencher currículos, fazer currículos para eles. Eu sei que eles falam, eles põem uma listinha de coisas de que eles necessitam do Português. Ah, deixar um bilhete para o familiar, escrever uma carta no Natal. Então assim, eles põem todos esses como caminhos para o uso do Português. Matemática? Por que é tão 
importante? Eles falam também. Parece que eles já sabem, eles trazem meio receitas prontas. "Ah, Matemática, professora? Poxa, está na vida! A gente faz conta o tempo todo, a gente tem que saber se o patrão não está lá enganando a gente, se o vendedor não está fazendo uma conta errada ou se quando vai fazer o desconto da porcentagem se o cálculo do desconto é real ou se aquele desconto não vai ter vantagem nenhuma, ou pagar em parcelas se vai ter ou não vantagem. Tem que saber porcentagem, tem que saber... ". Bom. Agora, qual é a importância do Inglês, da História, da Geografia? Eles jogam tudo no mesmo saco. Inglês, Geografia, História... E num saco fundo, sabe? É que assim, não tem nada a ver com a realidade. Aí há um tempo eu comecei a ter uma visão diferente da História. Comecei a perceber que alguns alunos começaram a perceber a História como uma disciplina, que antes eles não viam. Achavam que era uma conversinha.

P: (risos)

V: Juro! Era uma conversinha. Aí eles começaram a perceber. “Oh, o professor que dá aula de Geografia e dá aula de História, ele está trazendo ideias, a gente está aprendendo sobre mapas, as regiões do Brasil, onde a gente mora, as capitais. Então, começou a ter sentido. Ciências, eu falo muito de ciências nas minhas aulas. Pode que às vezes eu falo de corpo humano, de saúde, eu gosto muito. Nossa área integra também Educação Física. A linguagem da manifestação do corpo e refletir o estado que você está, né. Tanto a parte emocional quanto a parte de saúde física a gente trabalha muito na área de Linguagens e Códigos. Mas é um gosto meu, também, particular. Agora, o Inglês, olha só como ele acaba ficando meio que, vamos dizer, vazio... Primeiro, que todos os textos que vêm, que o grupo estabelece, são em Português que a gente vai fazer vagas...

P: Pontes? O que eu percebo, Vívian, é que você, pelo menos, isso não são escolhas isoladas suas, né. Que você prepara esse material em conjunto, passa pela aprovação de outros professores, inclusive de outras áreas, né?

$\mathrm{V}$ : Isso é importante.

P: Da importância desses conceitos, inclusive que você não conhece, como vitamina...

$\mathrm{V}$ : Isso.

P: Mas assim, a ponte que vocês fazem então é pelo vocabulário principalmente. E o que eu vi de texto foi a música. Isso causou uma resistência nos alunos. Outro texto que eu vi também foi na prova, a prova e a preparação que teve.

V: Eles tiveram as receitas, cardápios...

P: Ah, as receitas, o sistema de calorias da prova...então eu não vi, mas você mencionou. Eu não cheguei a ver. Mas esses dois meses que eu estive presente eles viram as músicas...

$\mathrm{V}$ : Textos em Inglês mesmo...

P: Não, aqueles completinhos. Com começo, meio e fim, né. Pirâmide.

$\mathrm{V}$ : Isso.

P: É. A tabela de calorias.

V: Nutricional. Que foi mais na prova e na pré-prova. Tabela de calorias a gente não usou, não fez aula com isso.

P: Mas eu percebi que eles tiveram que ler aquilo, achei interessante.

V: É uma leitura.

P: É uma leitura inclusive para a vida deles. Está bem próximo da vida deles. No primeiro módulo, ou no segundo, se não me engano, eles tiveram que ler a receita, é verdade, eu lembro.

$\mathrm{V}$ : Isso.

P: O que eu queria saber é o que você pensa a respeito desse trabalho com texto, que você já mencionou. Se é um desafio, se os alunos resistem, se você tenta colocar isso no seu trabalho...

$\mathrm{V}$ : Eu amo esse trabalho. Eu acho assim, o texto é o que está na vida. Aquele vocabulariozinho, decorar uma lista de nomes de partes do corpo, decorar uma lista de cores, uma lista, ele é necessário também? É. Só que o que que acontece? Quando o aluno recebe essa lista ele acha mais fácil.

P: Eles gostam, né?

V: Eles gostam.

P: Eles gostam de anotar, eles gostam de tradução. Eu lembro que quando eles esqueciam o livro e você saía da sala para buscar o livro para eles, eles ficavam perguntando para mim. "Professora, o que que é isso? O que que é isso?". Eles ficavam até envergonhados de perguntar, né, e eles queriam anotar tudo, tudo. Às vezes você colocava na lousa, acho que para o $3^{\circ} \mathrm{A}$, não lembro, que às vezes não colocava a tradução mais, você deixava em Inglês só.

$\mathrm{V}$ : Para eles tentarem pensar.

P: Aí você deixava e eles, "P, por favor..." (risos). Eles queriam ter aquilo tudo registradinho.

$\mathrm{V}$ : A questão parece que uma organização, o que eu sei, o que eu consigo entender é interessante para mim. O que eu não consigo entender tudo não é interessante.

P: Que é o texto? É como a A. reclamando. Ah, professora...

$\mathrm{V}$ : É muito complexo, nossa.

P: Então, por isso a questão do texto. Por isso eu queria que você comentasse.

V: Então. Cada sala é uma sala também. Numa realidade do Centro Educacional Trandisciplinar, eles não têm hábitos de trabalhar com textos em Inglês na vida real deles, né. 


\section{P: É, realmente.}

V: Vamos dizer. Uma palavra, jeans, baby look, funk, eles escutam palavras que às vezes eles não sabem nem que é inglês, como eu já te falei. Aí depois, eles começam a perceber que aquilo é Inglês, e começam e até acham interessante. Só que aí eles começam a buscar primeiro o que é mais fácil. Então, são listas de palavras, por quê? Não sei. Eu tenho uma tese, não está concluída, mas é assim: nós todos trabalhamos de forma organizada e queremos uma organização e queremos uma certa disciplina e isso traz um comodismo. Sabe aquela fase de acomodação? Então parece que nós ambicionamos tomar posse do conhecimento e esse conhecimento ele aparentemente para nós só chega quando está organizado.

P: Anotado, registrado, lá no caso deles, tudo mais, né.

V: Você entendeu? Uma lista de frutas, uma lista de alimentos, uma lista de partes do corpo, uma lista de cores, uma lista de números, para eles é muito mais fácil. É interessante. Eu falo muito assim: "Gente, não precisa saber tudo. Vamos saber pelo menos a cor que você prefere?"

P: Exato, eu vi você falando isso. Não dá para saber tudo.

V: Não precisa. Eu dou exemplo de mim. Gente, eu mesma tinha listas na escola mas eu decorava tudo? Não. Eu queria decorar. Mas você acha que eu conseguia? A gente tem outras preocupações, outras necessidades. O cérebro trabalha por necessidades. A gente já viu isso em várias palestras.

P: Só lembra daquilo que é importante.

V: Necessidade. Pelo menos nos estudos atuais, até aí, do que se passa para nós dos estudos. Porque não é tudo o que é estudado que passa para a gente. Resultados de pesquisa, muita coisa fica lá com os cientistas até que depois de anos e anos que chega no povão, né. Então, assim, noções que nós temos, que normalmente nosso cérebro trabalha por necessidades. Beleza, então vamos por necessidade. Tua cor preferida e a minha cor preferida, eu vou saber a minha e a do meu colega. Ah, vou saber que a cor blue e a cor black são usadas na vida real em termos ou em situações, às vezes até mesmo como o black. O blue é usado até num ritmo de música, um estilo musical, o blues. A gente vai começando a associar e aí sim faz sentido. O texto já é diferente. O texto para eles tem sentido quando é uma música porque já escutou, porque aquilo ele vai cantarolando (cantarola uma música).

P: Eu vi muito eles brincando. Eu não sei se era essa a sua ideia, pedir para que eles cantassem junto, mas que assim, que experimentassem, sem aquela correção.

V: Sem aquele Oh, meu Deus...

P: Vou praticar com correção.

V: Não. É o terceiro módulo. E assim, de repente também do que eles têm de experiência com isso. Muitos deles nunca abriram a boca durante uma música em Inglês. Ou até abriram mas têm essa vergonha, né. É a autoestima, né. Ah, não vou cantar errado. Então, eles têm muito disso. Já a criança aprende mais rápido por isso, por ela se soltar.

P: Então, a sua ideia ao preparar essa música, trazer o violão e tudo mais era qual?

V: Como uma criança, que está livre, sentir na música que está ouvindo e tentando imitar. E principalmente sentir. Primeiro, a gente mostrou a música no PowerPoint para eles perceberem e fazer sentido. Aí, eles gostaram da tradução, se familiarizaram mais com a ideia do Louis Armstrong cantando essa música e "Poxa, essa música tem temas interessantes, ela traz uma ideia interessante." Para o $3^{\circ} \mathrm{D}$ eu fiz uma experiência diferente porque eu amo fazer coisas diferentes com cada turma e cada turma é uma realidade diferente. $\mathrm{O} 3^{\circ} \mathrm{D}$ a gente vê que são muito mais, por mais que eles também não conheçam, eles têm um certo jogo de cintura que ainda muitos do $3^{\circ}$ A ainda não adquiriram. Pelo que eu observei, né. $\mathrm{O} 3^{\circ} \mathrm{D}$ eu dei pouco tempo de aula para eles. Quando eu comecei a dar aula para eles de Inglês inclusive, eles não gostavam de Inglês, falavam que não gostavam, depois a D. deu as aulas de Inglês, eu dei outras, e, não sei, eles começaram a gostar. Começaram a achar interessante, começaram a mudar de ideia.

P: O J. falou, principalmente depois das aulas da Vívian, comecei a gostar mais de Inglês. Foi o que ele me disse. V: Isso no terceiro módulo, imagina ano que vem. Olha que legal, eles terem contato com outros professores, outras dinâmicas de aula e tal. A A. e a F., eu não consegui conquistar muito. Mas o C., nossa!

(...)

V: Eu tenho um aluno no primeiro ano, da noite. Ele da manhã e foi para a noite, o G. Ele é muito engraçado. Ele chega assim, "Hello, teacher! Fine?(sons balbuciados, imitando Inglês)" Aí depois ele diz (sons balbuciados, imitando Inglês). É muito engraçado. E todo mundo da sala dele acredita que ele fala em Inglês.

P: Mas por não conhecerem, né?

V: E ele se sente. Aí na hora do debate, do diálogo, das atividades, ele saía da sala para beber água, ele faltava no dia que eu marcava. "Pô, mas o seu papel era para ser o pai da família, você não veio, G.?". "Ah, professora, sabe o que que é? Não sei que, não sei que..." Dava uma desculpa. Mas sempre. "Olha gente, mas na sexta-feira que vem, vai ter de novo e o G. não vai faltar dessa vez". Ele faltava de novo. Então, assim...

P: É, tem gente que tem uns recursos para...

V: Entendeu?

P: Enfim. 
V: Assim. Ninguém precisa que ele saiba, nem ele precisa que ele saiba falar Inglês, tudo. Talvez ele conheça algumas palavras, dá para ver que algumas palavrinhas, algumas coisinhas, ele conhece. Se você fala blue, "Que cor que é blue, G.?”. Ele, "É azul, não é professora?”. "Olha, está vendo?!”. Aí, todo mundo, “Aê!” (aplaude). A gente valoriza também porque eu acho que é importante valorizar a autoestima, mas a gente tem que tomar cuidado em não construir uma ideia, uma imagem, uma visão irreal. Acho que também é perigoso isso para o próprio aluno. Mas se ele quiser construir a visão dele igual aquele... tem um filme interessante daquela mocinha que constrói a visão dela de namorado, eu esqueci o nome, uma loirinha... Se ela quer construir a ideia de que ela fala Inglês e as pessoas acreditarem, se não for doentio, se não me atrapalhar, se não for invadir a minha privacidade, não sou eu que vou acabar com o sonho dele. Eu penso assim, pelo menos. Agora, tem aluno que sabe um pouco de Inglês? Sim. A R. é uma que fez um cursinho de Inglês já. O L. do $3^{\circ} \mathrm{D}$, também. Alguns sabem algumas palavrinhas pela Internet. O L. do $3^{\circ}$ A já fez quinta e sexta série, então ele estudou Inglês na quinta e na sexta, por isso que ele vai um pouquinho melhor do que os demais. Mas ele não se esforça. Ele é um aluno que...

P: Está sempre dormindo.

V: É.

P: Várias vezes eu anotei isso no meu diário. Até aprender o nome dele eu anotava, o aluno mais novo e tal.

V: Isso. E acontece muito. Ele quer ser o principal, ele quer ser importante. Na redação dele sobre a infância, isso daí é uma Vívian não psicóloga e não pedagoga que está dizendo, tá, é uma visão que eu tenho, na redação sobre a infância dele ele falou que sofreu muito na infância porque...

P: Problema de saúde.

V: Problema de saúde e que ele considera muito os amigos dele de infância e hoje em dia ele não tem amizades. No sentido de que ele não considera ninguém ao redor dele. Parece que a autoestima dele talvez não permita que ele aceite errar perto do outro. Não sei. Tem muitas coisinhas que andam nesse meio termo. Mas ele era um que quando chegava na prova e errava, “Ai, L., você não acertou essa daí, vamos pensar melhor?”. “Ah, professora, fala aí o que que é”. Você vê a preguiça daí. Ele sabe um pouquinho mais, então esse um pouquinho ele já acha que é poderoso. Esse poder faz com que ele se isole dos outros que não são poderosos, da turma que é fraca. Todo mundo sabe que ele cai bem na turma fraca.

P: Justamente.

V: Ele já mudou de horário três vezes e voltou para a turma fraca. Que barato, né? Será que não tem alguma coisa? Será que ele não foi para a outra turma e começou a não se ver como o mais importante?

P: E acabou voltando?

V: Pode ser.

P: Talvez no $3^{\circ} \mathrm{D}$, ele se desse melhor, né.

V: Nossa! Várias vezes a gente chamou ele para o $3^{\circ} \mathrm{D}$. A R. ficou fazendo reposição de aula no $3^{\circ} \mathrm{D}$, uma outra aluninha que era amiga dele da mesma sala. A T. também. Eles faziam reposição no outro terceiro e à noite também. Ele foi para a noite, foi para a manhã e voltou. Interessante.

P: Coisas que Freud explica. Uma última coisa, Vívian, o que você considera que os alunos precisam saber de Inglês hoje em dia?

V: Pergunta interessante. Se a gente for pensar quanto ao que precisa saber, quanto à necessidade do Inglês na vida prática, a cada momento, é uma situação nova. Talvez na vida da gente a gente vá se debater por uma situação que vá precisar de alimentos, vou viajar e preciso saber pedir um alimento. Numa outra situação, uma música que eu goste tanto e queira saber a tradução. Preciso saber usar um dicionário. Preciso saber entrar na Internet para procurar no Google Tradutor. Ou só lendo, fazendo uma leiturinha rápida, para que eu consiga captar a mensagem. As situações básicas que a gente percebe são situações que devem ser presenciadas na escola de uma maneira formal, acho que devem sim. Acho que o mais importante não é o conteúdo, entendeu? Não é, por exemplo, uma lista de palavras, porque isso ele consegue sozinho. Ele vai chegar no dicionário, "Ah, vou fazer uma lista de cores". Ué, procura e pronto. Ele vai procurar num livro. Tem os livros da biblioteca. Ele vai achar lista de cores nos livros, animais, lista de tudo. Acho que o mais importante não é isso. O mais importante é vivenciar algumas situações para eles não se assustarem quando for para a vida real mas ao mesmo tempo se assustarem. Porque o assustar, o "assustamento", olha eu criei uma coisa.

P: Bonito. Bem Guimarães Rosa, o "assustamento". (risos)

V: (risos) Esse "assustamento", até um confronto de algo novo sempre vai existir. Só que sempre no trombar com algo novo na escola e com outro algo novo no dia seguinte e com outro algo novo até o final do ano, quando algo novo chegar e ele estiver na vida sozinho, ele vai se assustar. Se ele não tiver, por exemplo, uma situação em que ele vai vivenciar algo novo sozinho, (mas) essa autonomia (não) vai ser trabalhada, (não) vai ser desenvolvida. Essa autonomia de vivenciar esse algo novo e encarar como algo normal, algo natural, algo que o tempo todo a gente vivencia, ele é necessário no Inglês. Acho também super necessário a questão do diferente. $\mathrm{O}$ vocabulário... Nada chegaria ao valor da altura de respeitar e de encarar o diferente como diferente e esse "assustamento", vamos dizer assim, ele vai se tornar muito mais natural quando você vivenciar esse diferente. 
P: Para tudo, na verdade. Vou falar... Você está falando as coisas que eu vi. Quando eu cheguei aqui eu tinha uma visão e isso foi se modificando e eu comecei a concentrar nessa outra visão. De você ficar mais pronto para a diferença.

$\mathrm{V}$ : Isso.

P: Para ver o "assustamento" de um jeito mais tranquilo.

V: Isso. Como mais natural. Tanto que, engraçado, né.

P: Mas sem perder a beleza.

V: A magia. É importante. Se ele for visto como uma coisa natural, normalzinha...

P: É chato, né.

V: Também é chato. Esse "assustamento" é importante, por isso que eu estou colocando em dois tópicos diferentes. O "assustamento" como algo novo e esse algo novo que sempre vai trazer crescimento. E o diferente como aquela questão do respeito. E quando vê o diferente, vê uma palavra nova, não dá risada da palavra. Eu até dou risada. Tem aquele que (gargalha apontando).

P: Tem aluno que fica... É. Umas reações que eu vi.

V: É natural. É natural. Num curso de idiomas, já tem menos. É assim, um por cento, dois por cento. Aqui, são oitenta por cento, noventa por cento que vão dar risada, é muito diferente. Porque ele está numa situação formal que ele está lá para aprender Inglês, ele meio que se coloca como o poderoso. Ele coloca no mesmo nível que os demais, estou aprendendo aqui como vocês, eu vou aprender. Agora, aqui, já não, aqui numa escola de EJA, ele já, "Inglês não é importante. Inglês? Ixi, na vida? Eu vou encontrar uma palavrinha ou outra. Eu não vou usar. Na minha profissão, eu não vou usar. Não vou viajar para fora." Ele fala essas coisas. Então, essa cultura diferente da dele também é vista como algo, a maioria dos alunos veem como algo que não faz parte da realidade, então é estranho, é esquisito, é errado. "Poxa, professora? Hot dog, eles põem o adjetivo na frente do substantivo? Ai, professora, eles falam errado, né?" "Eles falam diferente da gente. Como é que o nosso está certo e o deles está errado? Será que não é o contrário? Ou será que ambos não estão certos, cada um na sua visão?” “Ah, professora, mas é muito esquisito. Ah, não. O nosso é que está certo. Lógico.” Lógico! Olha!

P: (risos)

V: "Eu tenho certeza disso! É lógico!" Sabe esses termos assim? Isso está certíssimo! Isso é perfeito. Esses termos muito assim são muito da nossa cultura de achar que o nosso só está certo. Isso não só da nossa cultura, mas acho que no mundo de ver o nosso como certo. Ele precisa vivenciar em sala de aula situações diferentes. Por exemplo, gêneros textuais diferentes. Então, uma música, uma receita, uma tabela nutricional, uma poesia em Inglês, a música é quase uma poesia, um conto que nós vamos ler ano que vem, fábulas e contos. Ele precisa vivenciar um pouquinho. Não precisa ser tudo, entendeu? Um pouquinho de cada uma dessas coisas. Uma outra coisa que eu acho importante desenvolver neles são certas habilidades, por exemplo, de saber que não vai ter domínio de tudo. Essas habilidades do tipo, um jeito de encarar o mundo de que eu não vou ter domínio de tudo para eu aprender; eu não preciso disso. Não há necessidade desse domínio de tudo para eu aprender. Que eu posso errar, que é muito difícil, e aí a gente tem que desenvolver em todas as disciplinas, mas o Inglês traz uma possibilidade. Qualquer língua que você vá ensinar, Inglês, Português, eu acho muito interessante porque o errado é vivenciado. Porque o aluno acha errado usar um adjetivo antes do substantivo, ou acha errado pôr um ponto de exclamação de ponta-cabeça no Espanhol, ou acha errado falar errado.

P: Errado falar errado.

V: Não é?

P: Ontem eu estava vendo no Vídeo Show, estava em casa fazendo almoço (risos)

V: Gostoso.

P: E aí um personagem, acho que da $A$ Grande Família estava lá sendo homenageado, acho, é o Evandro Mesquita que interpreta ele, eu adoro ele. Eu não sei o nome do personagem porque eu não assisto A Grande Família, não sei se você assiste.

V: Eu assisto. É um dos funcionários daquele Augustinho. Não sei o nome dele também.

P: Acho que estava o Augustinho também sendo comparado com ele, é verdade. E aí era isso, o cara fazia, ah, mas ele fala errado, porque ele fala errado. E essa questão de ele ser todo errado porque ele fala errado... O cara fala assim, "É, porque eu fui lá para o sunpretivo, eu tenho sunpretivo! Eu tenho diproma! Eu tenho diproma!" V: Nossa...

P: E eu vi recentemente que agora tem as interações das pessoas que estão assistindo e colocam na internet, eles publicam ali. Mostram lá embaixo, né.

$\mathrm{V}:$ Ah...

P: "É uma metralhadora de erros". Eu fiquei pensando. Isso é super divulgado. As pessoas pensam assim por elas mesmas, claro, mas isso é estimulado também. E o aluno de EJA ali retratado. "Eu fiz sunpretivo!"

V: Interessante essa questão do erro, de aceitar o erro. De encarar como... Por que erro? Ué? Ele é um caminho para o acerto e será que a vida toda eu preciso acertar o tempo todo? Eu tenho muito questionamento em cima dessa questão do erro, que dá muita discussão. Tem tantas coisas que são necessárias de desenvolver, mas você vê como são? Essa questão de dominar tudo, de acertar e errar, de aceitar o diferente. Essas questões são 
trabalhadas dia-a-dia. Todo dia, um pouquinho, doses homeopáticas, você vai chegando lá. Vocabulário mesmo, você vê, não é tão necessário. É necessário também? Sim, como forma de organização, até. Por que não propor ao aluno que ele mesmo organize o material dele? O que eu aprendi hoje? A gente faz isso no Estado. O que eu aprendi na aula de hoje, nesse conteúdo desse capítulo? Aí ele escreve o que ele aprendeu. A gente faz muito a auto avaliação para que eles falem. O que vocês aprenderam, o que vocês gostaram na aula de hoje, na aula dessa semana, ou escreva alguma coisa, faça uma auto avaliação sua. Eles estão começando a ser mais autônomos. Essa autonomia também é muito necessária.

P: Queria perguntar duas coisas em relação a isso. Então, como...

V: Falta só o assunto da gramática.

P: O quê?

V: Não, depois eu falo.

P: Pode terminar, então.

V: Eu ia falar que essa autonomia é necessária para eles mesmos se organizarem, organizarem o saber deles e aí você pode até me questionar. Mas e a gramática? Ela é necessária? Sim, também. Tudo é necessário. O tradicional, o atual, o renovado, o construtivismo. Tudo é necessário. A gente tem que ter um pouquinho de tudo. É necessário ele escutar uma música, ele ver um filme, vivenciar um pouquinho essas situações e trabalhar com a gramática, sim. Por quê? A gramática também é uma questão de organização. Autonomia tanto no vocabulário quanto na gramática porque a gramática auxilia a gente a compreender melhor os termos, até a usar, saber como usar, dar uma base para o uso. É necessário o listening e o repeat? Sim, também. Porque se ele nunca vivenciar de vez em quando um exercício de ter que escutar e repetir, se mais para frente ele precisar, ele não vai saber a hora de parar de falar e escutar. É também questão de sensibilidade até. Tem aluno que só quer ele falar. Quando o outro colega começa a falar, de qualquer coisa, experiência da vida, ele para. Ele não dá valor. Se você ver, até o listen and repeat são necessários. A questão do respeito ao outro, o momento de falar, o momento de escutar. Acho que é isso.

P: O novo e o velho também. Você não acha que tem que ser radical. Agora, a gente vai...

$\mathrm{V}$ : Abolir a gramática. O texto é rico em gramática. Todo texto tem gramática. Tem texto que vai ter gramática errada ou gramática popular. Sim, ué. Nas blusas deles, às vezes quando eles vêm com a roupa escrito com um termo mais informal do Inglês. é que você não vai achar no dicionário. Ah, e o dicionário também. O dicionário não pode ser banido.

P: Saber localizar, saber distinguir o que serve. Às vezes o uso

V: Naquela situação. Já houve muitas experiências do cara ter um dicionário em casa e como ele começou a gostar mais do Inglês. Eu, minha mãe. Sabe, muitas pessoas, porque enquanto ele não tinha o dicionário, mesmo dicionário baratinho, dez reais, o que eu sei é o que a professora explica, entendeu? A partir do momento em que ele tinha o dicionário e foi proposto para ele para ele tentar traduzir uma frase...Olha só como é importante também. Vamos tentar, vocês vão tentar traduzir uma frase. Muitas vezes ele tem a autoestima de, "Opa, eu sou capaz. Eu não consigo hoje com o dicionário eu vou palavrinha por palavrinha, caçar no dicionário, catar milho, igual na informática. Mas uma hora eu vou melhorar. Essa palavra he eu já conheço agora dessa vez; she, já conheço dessa vez; love, já conheço dessa vez. Vou traduzindo as demais". Isso daí é necessário também. Aquele aluno que nunca pegou no dicionário, ou que nunca teve esse momento da autonomia dele, ele não acredita nele, ele não constrói também a autoestima dele. O dicionário é considerado o pai-dos-burros acaba, muita gente fala "Ah, professora, não vou procurar no dicionário não", nem em Português eles procuram... A escola oferece o dicionário de graça para eles, eles não trazem, deixam em casa. A gente tem que pegar o dicionário. A gente até fala, "Olha, pessoal, na aula que vem, a gente vai usar o dicionário, tragam o de vocês". Um traz. Mas isso por quê? Porque eles não querem carregar o pai-dos-burros. Ainda tem isso, $\mathrm{P}$.

P: Ainda tem essa visão, né.

V: Ainda tem essa visão. Incrível, né? Tem um ou outro que ainda fala "Não, porque eu procuro, e não sei o quê...”. Hummm, será? Você acha que ele sabe?

P: Sobre a mediação, então, para se chegar a essa autonomia. Como você vê? É um papel interessante esse o do professor. De ao mesmo tempo ser o professor, aquela pessoa que está fazendo uma ponte, mas que ao mesmo tempo quer que ele caminhe sozinho.

V: Perfeito. Eu sempre privilegiei isso nas minhas aulas, na minha visão. Porém, nem sempre eu consigo fazêlo. Eu ainda estou a um caminho do equilíbrio entre o paternalismo/maternalismo em sala de aula. Aquela questão de você deixar o aluno também fazer sozinho. Eu acho que esse deixar fazer sozinho, ele primeiro tem que ter realmente um trabalho de bagagem, de valorização da autoestima. Eu só vou realmente valorizar minha autoestima, me valorizar se eu tiver um mínimo de fé em mim. Poderia até usar esse termo fé. O aluno chega para a EJA, principalmente, muito descrente nele e daí a nossa dificuldade também de trabalhar com isso, mas a gente não pode descartar que ele é capaz. E muitos de nós professores descartamos que eles são capazes e fazemos por eles. Você percebe isso às vezes? Pegamos na mão dele na informática, "Olha, não sabe." [faz o gesto com as mãos de quem está mexendo no computador]. Principalmente na informática. Pegamos na mão dele em vez de falar, "Não, está lá! Pega no mouse! Você consegue! Olha! Põe o dedinho aqui." E toda aula tem que 
repetir. Põe o dedinho aqui, a mãozinha dura. Tem que ajudar. Mas aí tem que ajudar, não fazer sempre por ele. Se fizer sempre por ele, ele vai achar que está manjando de informática, vai chegar no computador da casa dele e não vai fazer o que ele faz aqui. Faz entre aspas, né. Será que faz ou o professor é que fez por ele? O dicionário aqui é a mesma coisa. Ele tem que às vezes mandar bala sozinho. E tem hora que, no começo do ano foi um sufoco, teve aluno que chegou a chorar usando o dicionário porque não queria e saiu da sala. "Ah, não, professora. Ah, isso não serve para mim." $3^{\circ} \mathrm{A}$. O $3^{\circ} \mathrm{D}$, eu não sei porque eu não acompanhei, mas no $3^{\circ} \mathrm{A}$ eu lembro de muitas situações tristes porque o aluno chegava, pegava aquilo e dizia, "Ai, professora, eu não sei nem a ordem alfabética." Aí, a gente trabalhou a ordem alfabética, trabalhou, trabalhou, trabalhou. Nossa! A maioria pegou. Me senti feliz, foi a maioria, né. Mesmo assim, teve uns que não (?), nós tivemos que continuar. E na hora que entrou o dicionário bilíngue? "Professora! Nossa! Tem dois lados". Eles começaram a perceber que tinha dois lados, que a palavrinha era a mesma coisa, o mesmo esquema, primeira e última palavra estão na página, então não dá tanto trabalho assim para procurar mas a palavra era estranha. Então você começa a olhar e vê uma outra palavra parecida, você acha que é aquela. É igual no começo do ano que eles estavam sendo alfabetizados. Ele via uma palavra parecida com a outra, ele não discernia em Português casa e casebre, por exemplo. Começa igual? Pronto! É essa! Vou copiar! Não percebe. Ele tem que começar a comparar, ver as diferenças e para isso a gente [fala] “Olha! Observou bem?”. É difícil com tanto aluno na sala também, apesar que aqui a gente tenha menos, né. Mas é complexo e você precisa dar um suporte. Eu não posso pôr isso como "Oh, meu Deus, eu não consegui" porque as condições também possibilitaram ou não. Eu sou aquele tipo de professora assim, P. , que não descansa um minuto para fazer o diário. Às vezes eu fico dias sem fazer porque eu fico lá passando pelas carteiras. Eu sou muito paternalista.

P: Você não senta, aliás. Você não senta.

V: Praticamente não sento. Fund I, então, eu não sento. Eu fico só andando. Às vezes eu fazia uma força para sentar, porque senão, “O que vão pensar de mim? Que não registra?” Mas eu registro. Minha agenda é toda cheia, é um rascunho. Eu anoto, depois eu passo a limpo.

P: Tem que passar a limpo depois, acaba dobrando o trabalho.

V: Acabo dobrando o trabalho. Eu penso muito mais neles do que em mim, o que não é legal. O que precisa haver, que foi a sua pergunta, é o equilíbrio, que não é fácil mas é necessário. Você dosar o momento de explicar para ele, o momento de auxiliá-lo e o "Agora vocês vão fazer sozinhos". Por isso que precisa dar uma situação que tenha mais ou menos as mesmas realidades para depois você cobrar aquela mesma só que você tem que saber também que muitos não vão conseguir porque cada um tem o seu tempo e não é por causa disso que você vai cobrar e falar, "Nossa! Aquele teve um resultado, então ele vai tirar P e o outro que não alcançou o resultado almejado por mim não vai tirar P”. Eu não penso assim. Eu acho que o P e o S, as notas, vão depender do avanço do aluno. Então eu avalio a A., por exemplo, como uma pessoa que avançou demais, apesar que ela ainda tem muitas dificuldades, ainda não acredita muito nela, mas avançou demais quanto a habilidades, competências que ela foi adquirindo, foi desenvolvendo nela. Já tem outros alunos que não avançaram quase nada e são alunos considerados P, Plenamente Satisfatórios, porque eles sabem mais do que toda a turma. Igual, por exemplo, o L. é considerado um aluno $\mathrm{P}$, todo mundo dá $\mathrm{P}$ para ele. Eu não daria, eu dei porque ele concluiu as atividades. No final do ano ele deu um (?) assim. Veio direitinho, não faltou, fez praticamente tudo - não fez tudo: ele fugiu da obra de arte, começou a pintar e falou que me traria no outro dia, não trouxe nem as tintas, nem o pincel que ele levou pra casa e o papel... Veio tocar [nos ensaios para a formatura dos alunos do $4^{\circ}$ módulo] comigo, mas aí olha...

P: Eu vi ele tocando com você e fiquei com uma visão mais positiva, olha que interessante. Ele se interessa.

V: Ele tocou, ele ajudou. Por isso que a gente tem que desenvolver as várias habilidades. Ele não quis fazer a pintura, não quis ficar em sala de aula fazendo a interpretação e texto mas ele teve um outro texto, um texto musical aqui em cima [no último andar da escola, no espaço de eventos, onde a entrevista foi realizada], que ele gosta e se interessa. Quando eu trabalhei com música na sala deles, eles gostaram. "You are my Sunshine ", que eu trabalhei com eles, que eu trabalhei no Fund I, ele se interessou, trabalhou, fez. Então, o professor tem que ter esse jogo de cintura também de [perceber que] o aluno não desenvolveu aqui, mas desenvolveu lá. Está bom. Parece que ele não caminhou muito, não fez quase nada das atividades pedidas, não realizou o solicitado, não foi responsável. No emprego, na vida, ele vai ser um irresponsável, não é assim? Porém, ele desenvolveu outros talentos, outras habilidades que também podem ser considerados. Ele teve interpretação? Sim. Oralmente ele interpretou muita coisa para mim. Mesmo não escrevendo. Na prova ele interpreta? Interpreta bem na prova e faz. A gente tem que ter esse jogo de cintura.

P: Uma última pergunta. Tem uma visão também de Inglês que as pessoas associam bastante, na era da globalização e da sociedade informatizada, que é o Inglês que abre mercado de trabalho. Como você vê essa visão? Uma visão que muitos alunos têm também.

V: Muitos alunos vêm para a gente com esse intuito. Os poucos que se interessam em aprender Inglês trazem justamente essa ideia da globalização, da necessidade para o trabalho, que quem tem Inglês ganha o dobro. Eles falam isso. Quem sabe Inglês ganha mais, consegue empregos melhores. Eu trabalho com eles essa ideia. Eu critico e também valorizo. É a questão do equilíbrio. Então, eu falo para eles, “Sim, vai ajudar. Qualquer língua 
que você tiver vai ser muito importante”. O Espanhol, por exemplo, hoje em dia também é muito útil. O Inglês em particular, por ser uma língua que tem uma gramática mais acessível, se a gente for pensar, comparando com a língua Portuguesa, a gramática da língua Portuguesa é muito mais complexa. Quando eles começam a falar da globalização, da importância do Inglês, eu sempre valorizo. Eu entendo como uma ferramenta nas nossas mãos para fazer com que eles se interessem em aprender algo novo. Qualquer coisinha que a gente consiga pegar, qualquer gancho para a gente trazê-lo para o estudo em geral, não só do Inglês, de todas das línguas que ele se interessar, apesar de eu defender a minha sardinha, eu sempre considero. Tem aluno que fala, "Nossa, professora! Eu não gosto de Inglês, mas eu gosto muito de Francês, eu vou estudar no Centro de Línguas". Eu valorizo. Foi através do Francês que eu comecei a gostar do Inglês. E eu falo para eles, "Quem sabe?". Eu valorizo. Tem que ser valorizada essa questão da globalização, só que a gente tem que tomar cuidado para não fazer uma ideia sonhadora demais de que você estudando Inglês vai abrir portas para você em tudo. Ou você, só com o Inglês da escola consiga... porque ele constrói um sonho, sai daqui traumatizado ou mesmo "meu mundo caiu" (cantarola). Porque ele acha, ele fala assim, "Professora, quando eu aprender Inglês eu vou conseguir o melhor emprego do mundo" e a gente sabe que não é assim. É útil? Utilíssimo! É necessário saber, é necessário se atualizar o tempo todo. O cara que sabe Inglês se atualiza o tempo todo, ele é tradutor-intérprete, ou ele vai trabalhar com Inglês na área, vai trabalhar com turismo. É importantíssimo. Olha quantas profissões têm associadas ao Inglês. Olha quanto Inglês tem na informática, quanto Inglês tem na música, na cultura, nos filmes. Só que ele precisa saber que essa globalização tem também um interesse por trás. Ele tem que conhecer ou pelo menos se questionar sobre isso. Será que é a minha tábua de salvação no meio do mar? Ou mais um caminho a trilhar? Eu um caminho importante? Eu não posso defender tanto a minha sardinha a ponto de fechar os olhos para os outros.

P: É, isso aí. Vá pensando que vai ser super fácil e vai estar tudo garantido. Não é assim.

$\mathrm{V}$ : Eu penso dessa forma a globalização. Mas falta alguma coisinha?

P: É isso mesmo. Justamente. Já imaginava que você teria essa posição crítica, claro.

V: É. Eu nem... Hoje eu dia eu amo a língua Inglesa. Eu estudo, eu olho, eu vejo. Quando eu comecei a ensinar para a criançadinha, acho que eu já te falei, eu não sabia muitas palavrinhas e tive aprender teto, parede... Não sabia teto, telhado, sabia azulejo, piso. Isso fez falta para mim? Não. No momento em que eu precisar eu vou lá no dicionário. Aí que é importante desenvolver essa autonomia. No momento em que eu precisar, eu olho lá e pronto. Agora, eu preciso saber do que eu estou falando. O cara está falando sobre animais; se eu não souber o básico dos animais, eu não vou nem perceber que o texto dele é sobre animais. Então, é necessário ter um básico de vocabulário e o que é esse básico? As palavras que a gente mais vê e usa em Português também. É isso aí. P: Vívian, obrigada. 